\title{
Acyl Cyanides as Bifunctional Reagent: Application in Copper-Catalyzed Cyanoamidation and Cyanoesterification Reaction
}

Zhengwang Chen, ${ }^{*}$ Xiaowei Wen, Weiping Zheng, Ruolan He, Dou Chen, Dingsheng Cao, Lipeng Long, Min Ye*

Key Laboratory of Organo-Pharmaceutical Chemistry of Jiangxi Province, Gannan Normal University, Ganzhou 341000, PR China

E-mail: chenzwang@126.com; yemin811@gnnu.cn

Table of contents

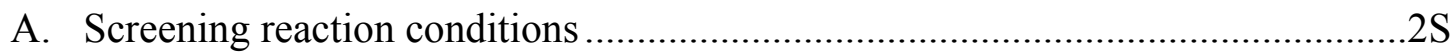

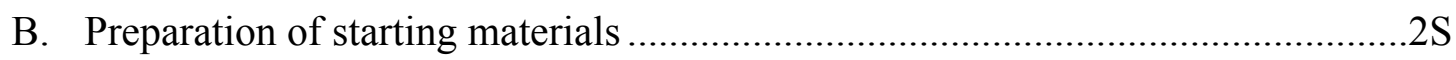

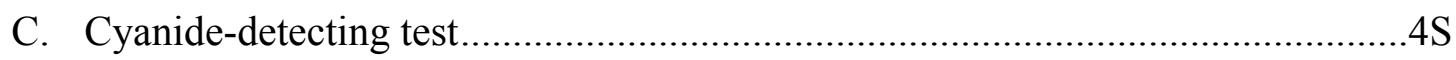

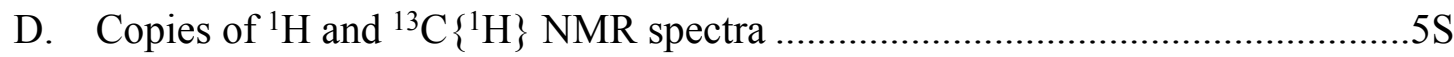




\section{A. Screening reaction conditions}

Table S1. Optimization of the reaction conditions ${ }^{a}$

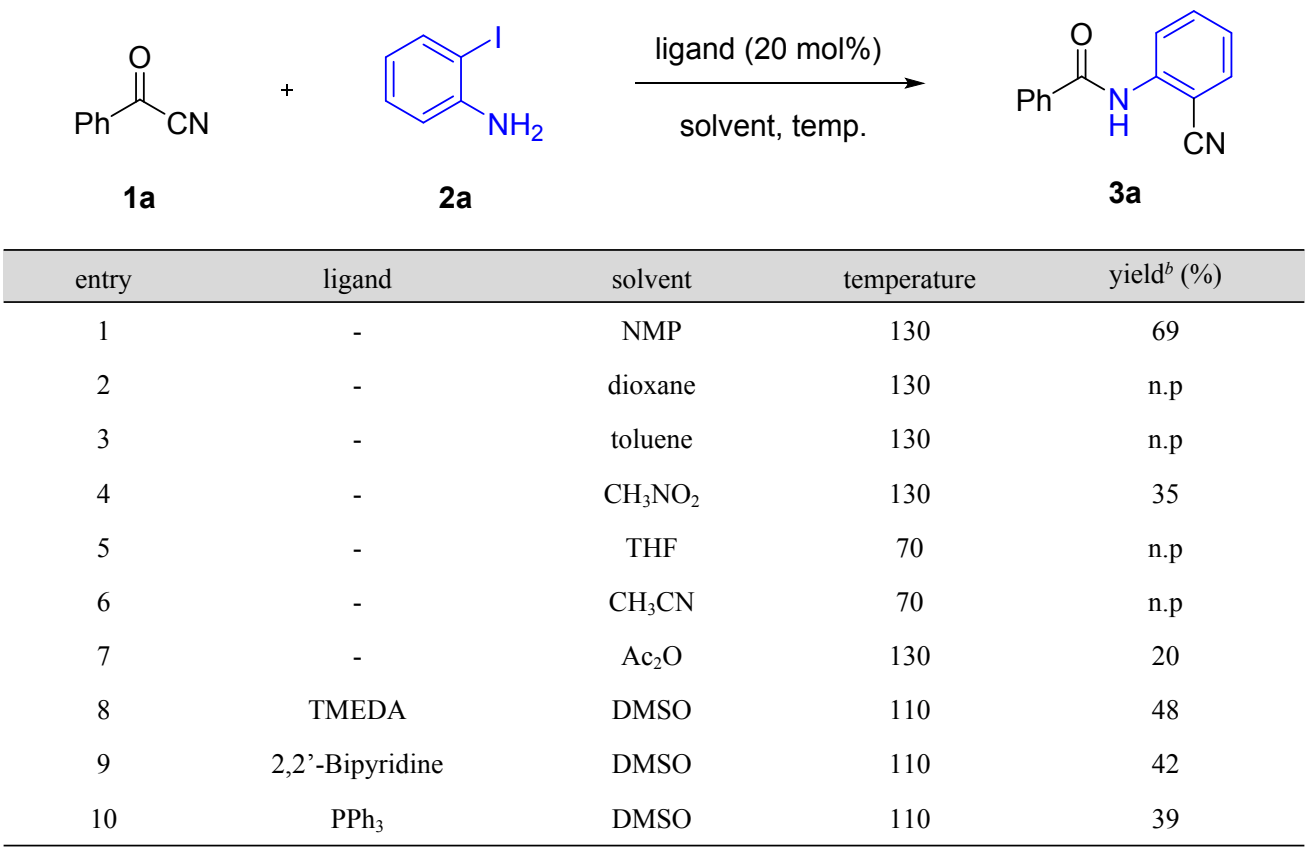

${ }^{a}$ Reaction conditions: $\mathbf{1 a}(0.2 \mathrm{mmol}), \mathbf{2 a}(0.2 \mathrm{mmol}), \mathrm{Cu}_{2} \mathrm{O}(10 \mathrm{~mol} \%)$ with ligand (20 mol\%) in solvent $1.0 \mathrm{~mL}$ for $10 \mathrm{~h} .{ }^{b}$ Determined by GC with mesitylene as internal standard. n.p $=$ no product.

\section{B. Preparation of starting materials}

The route toward substituted acyl cyanides:

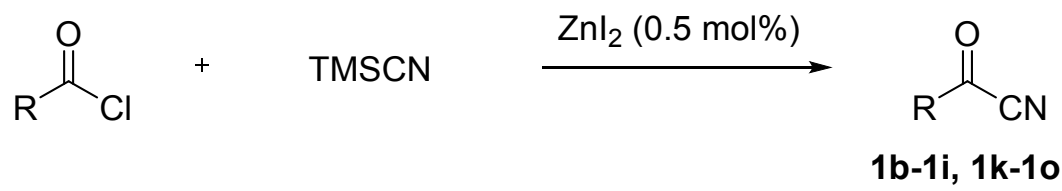


<smiles>N#CC(=O)c1ccccc1</smiles>

$1 \mathrm{a}$

Commercially available<smiles>N#CC(=O)c1ccc(F)cc1</smiles>

$1 e$

Known compound<smiles>N#CC(=O)c1ccc(Cl)nc1</smiles>

Known compound<smiles>N#CC(=O)c1ccc(I)cc1</smiles>

$1 \mathrm{~m}$

Known compound<smiles>Cc1cccc(C(=O)C#N)c1</smiles>

$1 b$

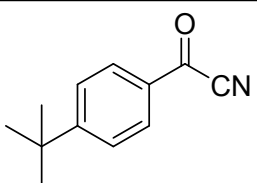<smiles>N#CC(=O)c1ccccc1Cl</smiles>

$1 f$

Known compound<smiles>CC(=O)C#N</smiles>

1j

Commercially available<smiles>N#CC(=O)c1cccc(I)c1</smiles>

1n

Known compound 1c<smiles>COc1ccc(C(=O)C#N)cc1</smiles>

1d

Known compound<smiles>N#CC(=O)c1cccs1</smiles>

1h

Known compound

Known compound<smiles>CC(C)(C)C(=O)C#N</smiles>

$1 k$

Known compound<smiles>N#CC(=O)c1ccccc1I</smiles>

10

Known compound

Scheme S1. The substituted acyl cyanides. 


\section{Cyanide-detecting test}

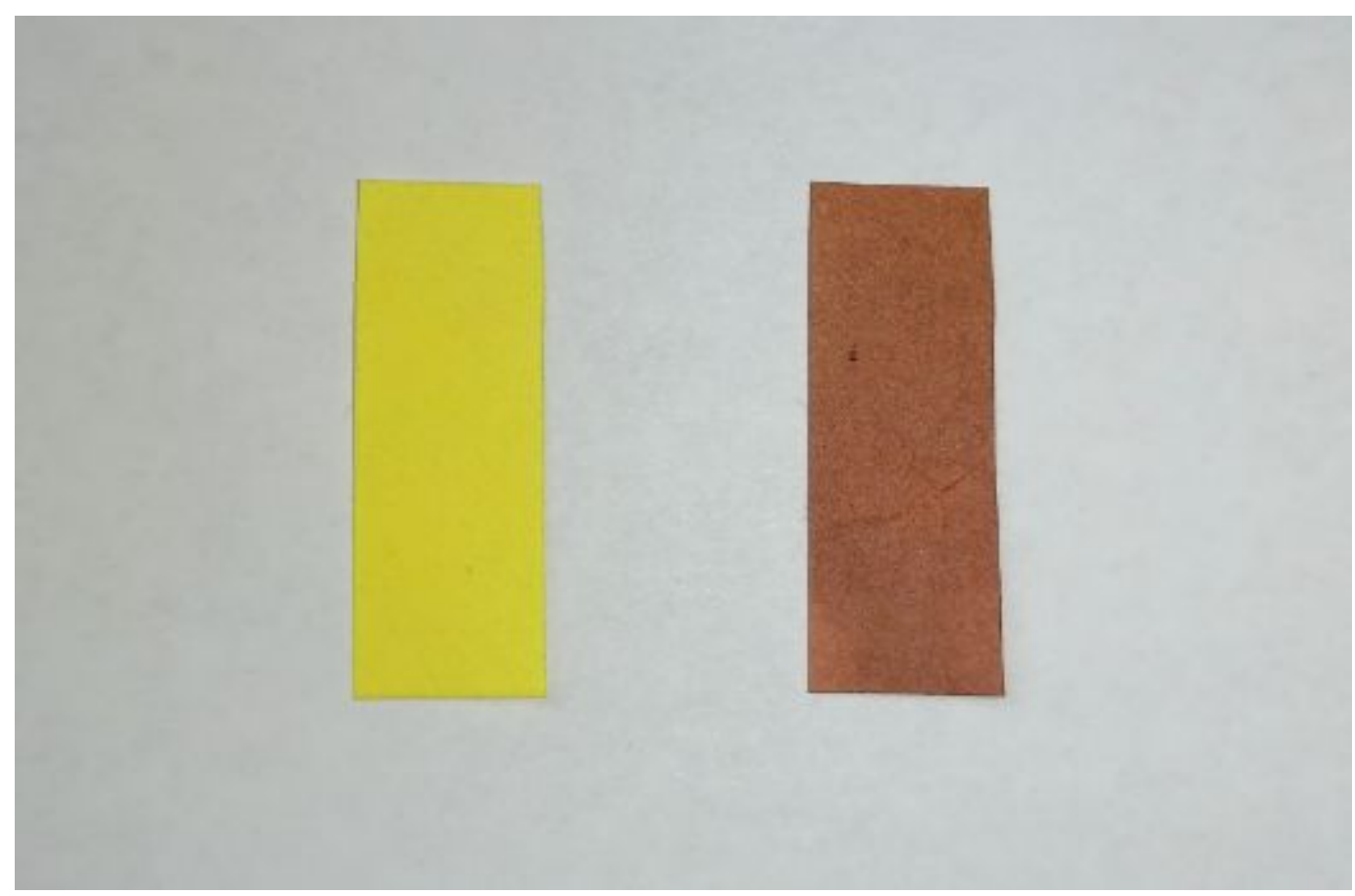

a The color of picrate impregnated indicator paper changed from yellow (left, blank) to red (right, after absorbing $\mathrm{HCN}$ ).

Scheme S2. Detection of cyanide anion by indicator paper. 


\section{Copies of ${ }^{1} \mathrm{H}$ and ${ }^{13} \mathrm{C}\left\{{ }^{1} \mathrm{H}\right\}$ NMR spectra}

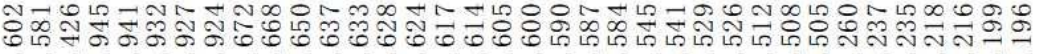

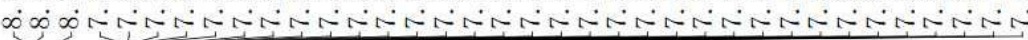
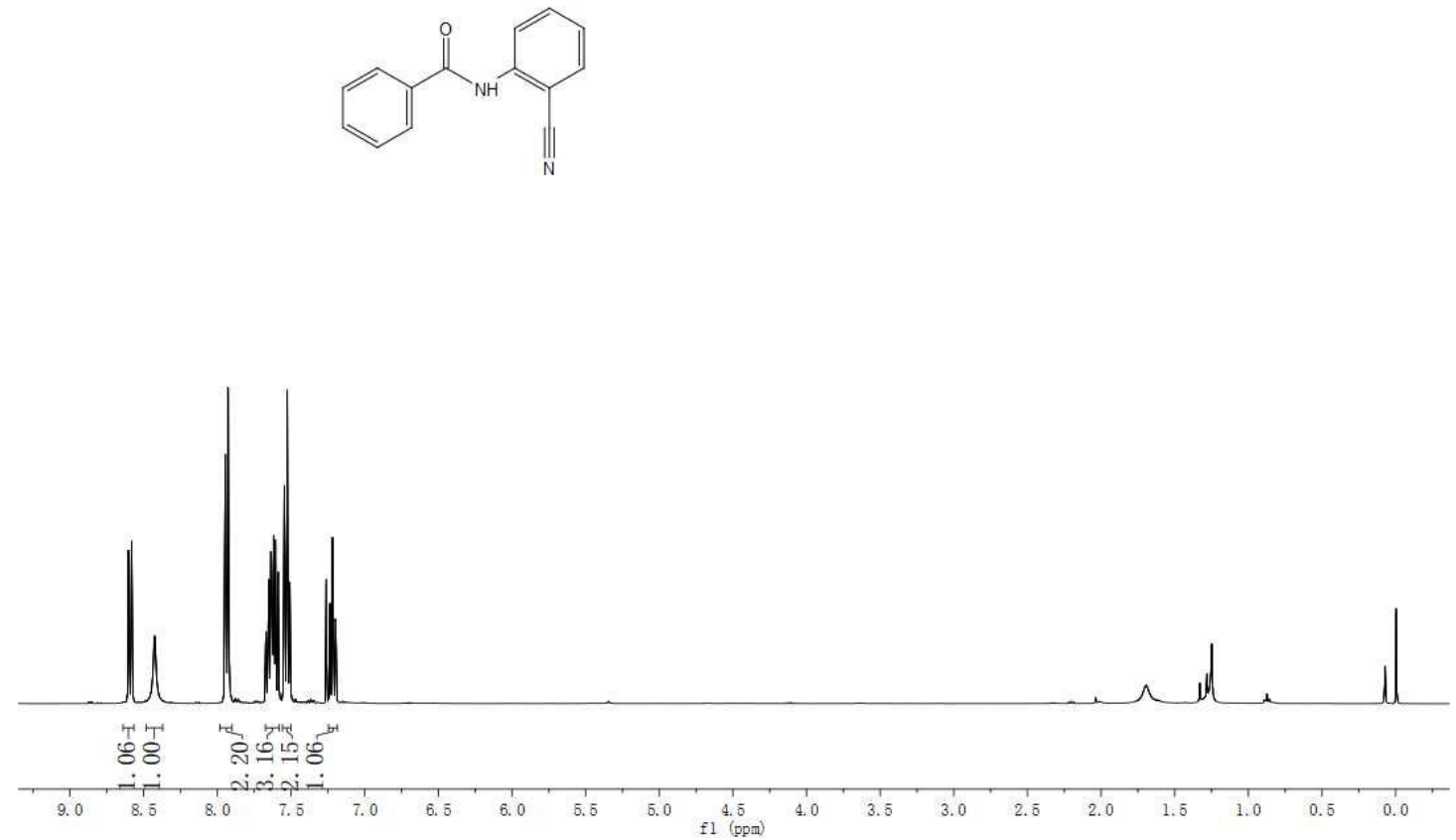

Figure S1. $400 \mathrm{MHz}{ }^{1} \mathrm{H}$ NMR spectrum of $\mathbf{3 a}$ in $\mathrm{CDCl}_{3}$.

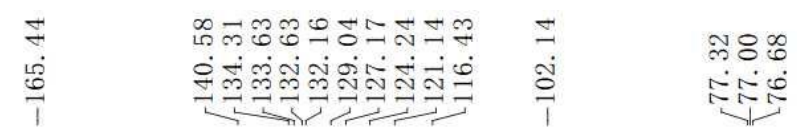
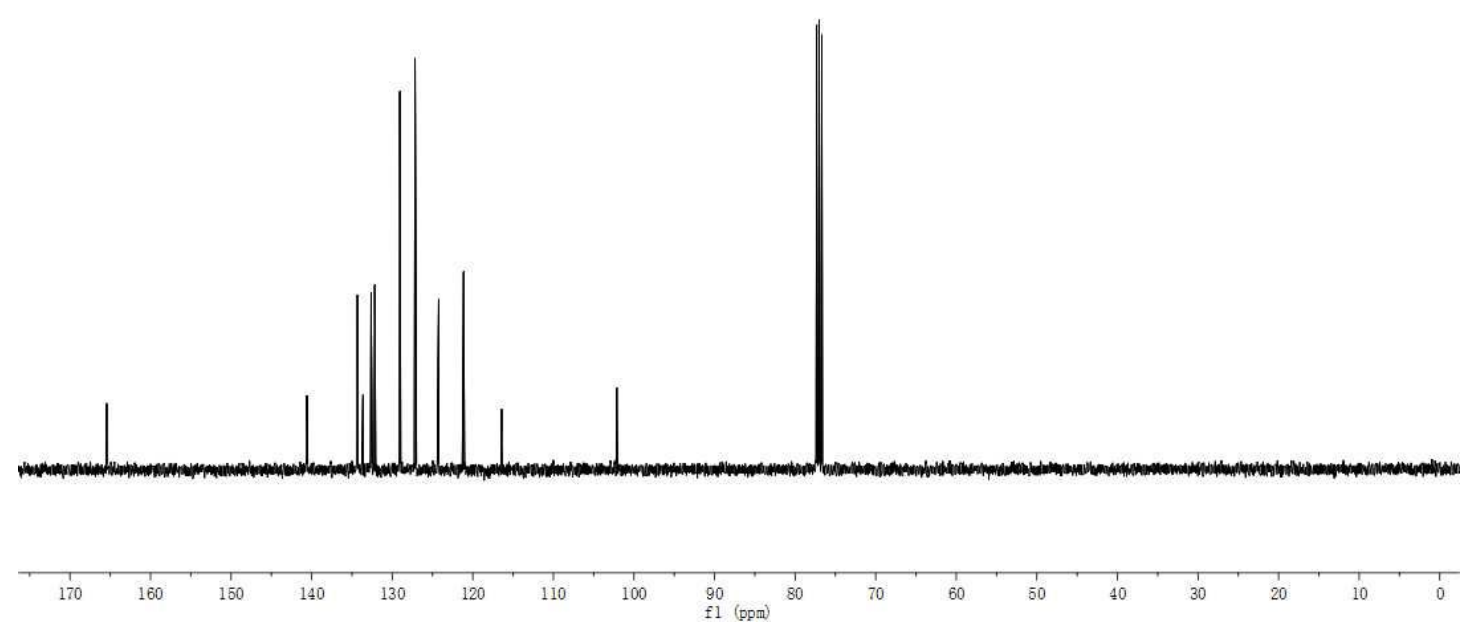

Figure S2. $100 \mathrm{MHz}{ }^{13} \mathrm{C}\left\{{ }^{1} \mathrm{H}\right\} \mathrm{NMR}$ spectrum of $\mathbf{3 a}$ in $\mathrm{CDCl}_{3}$. 

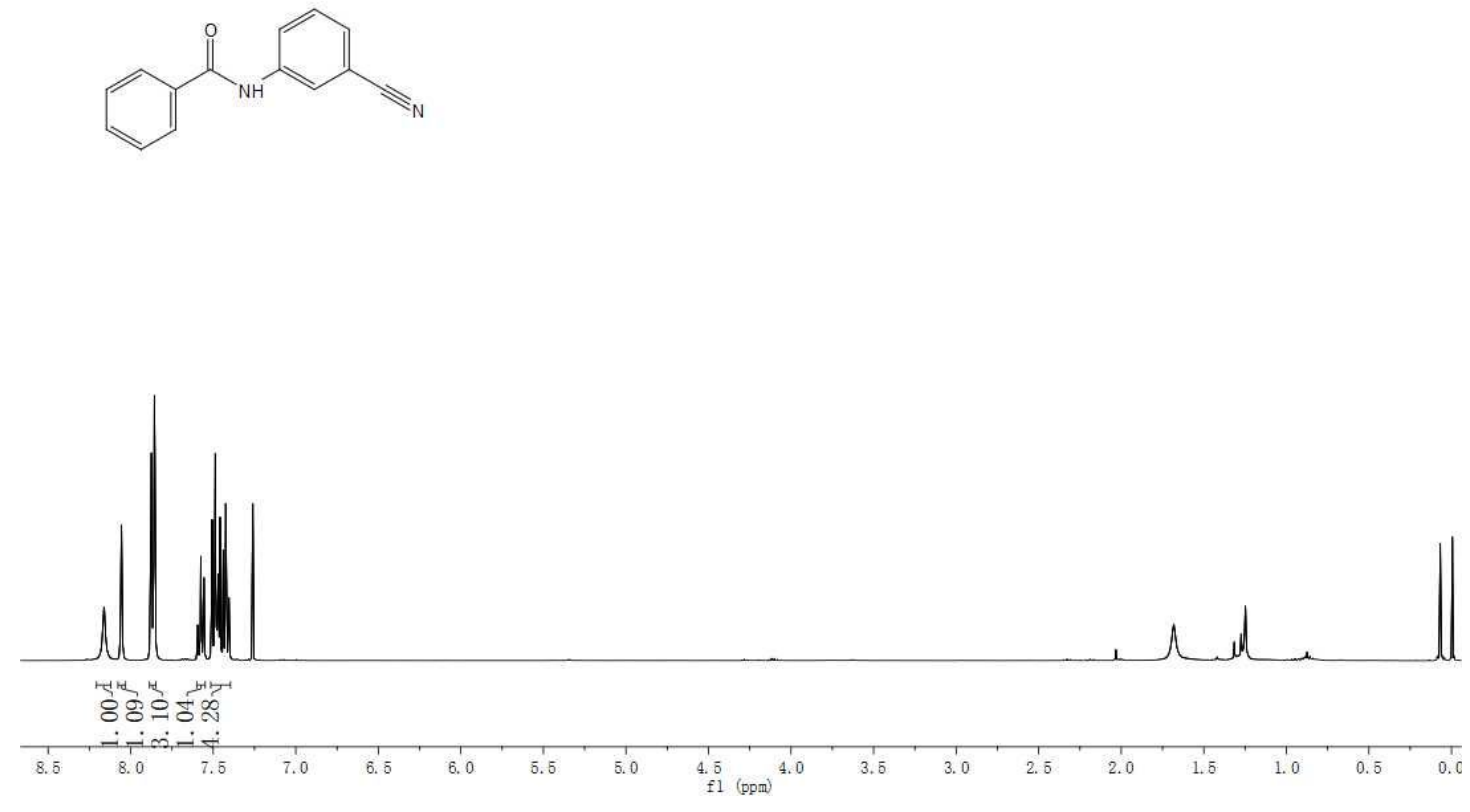

Figure S3. $400 \mathrm{MHz}{ }^{1} \mathrm{H}$ NMR spectrum of $\mathbf{3 b}$ in $\mathrm{CDCl}_{3}$.

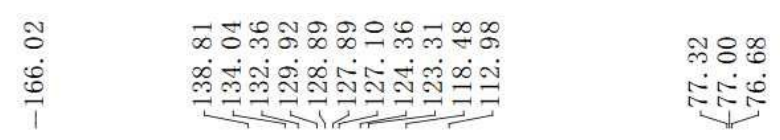

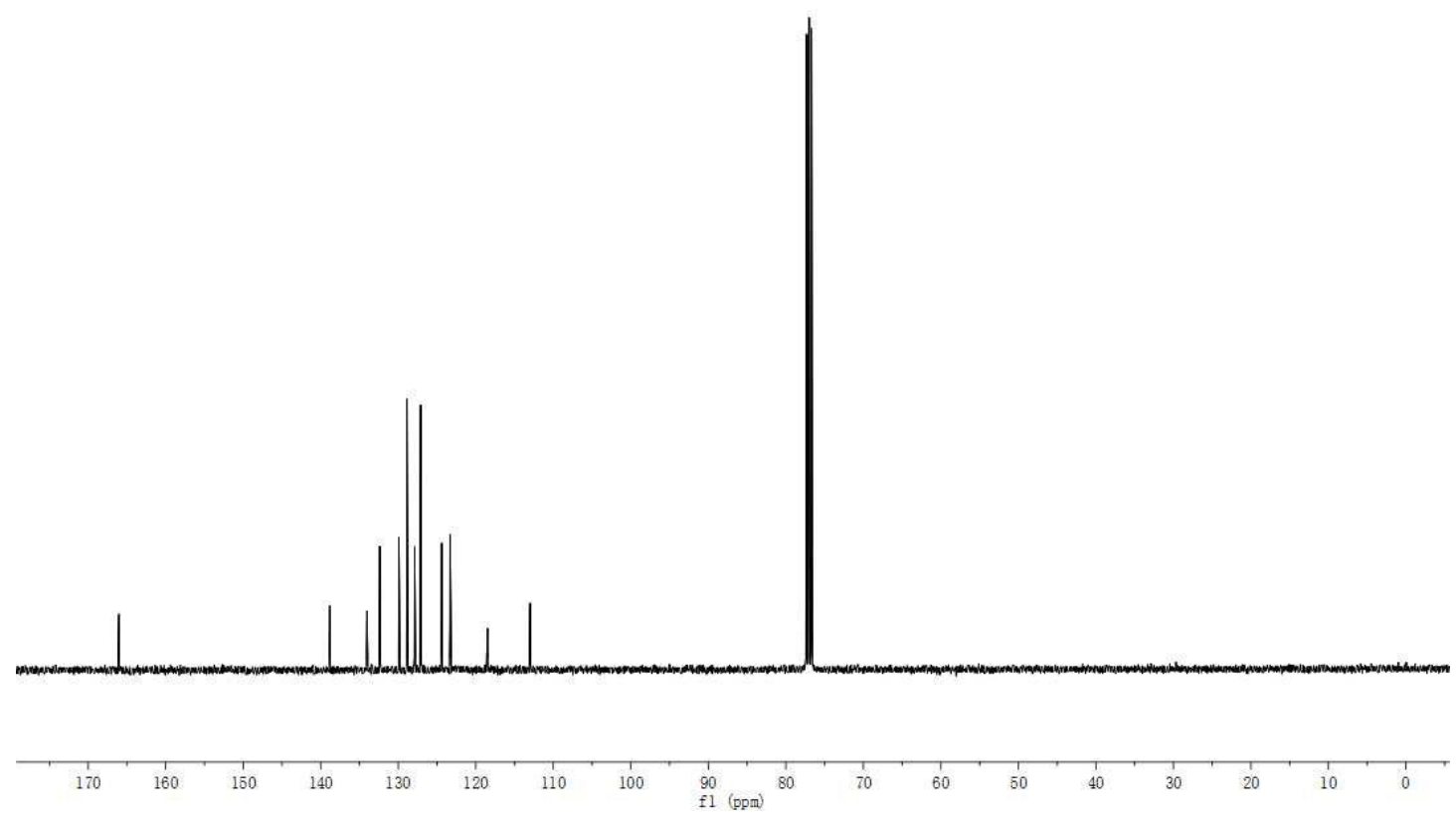

Figure S4. $100 \mathrm{MHz}{ }^{13} \mathrm{C}\left\{{ }^{1} \mathrm{H}\right\}$ NMR spectrum of $\mathbf{3 b}$ in $\mathrm{CDCl}_{3}$. 

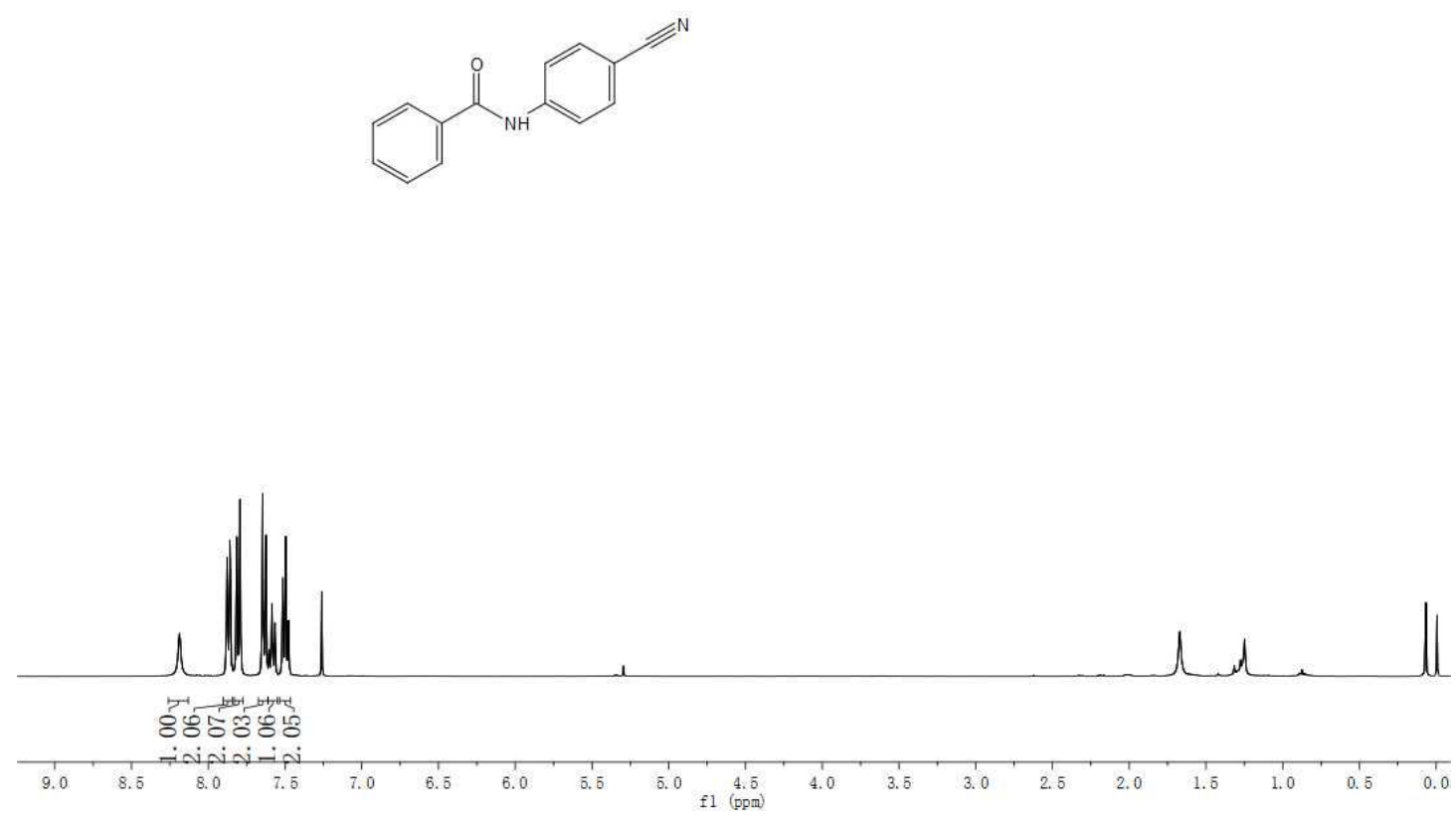

Figure S5. $400 \mathrm{MHz}{ }^{1} \mathrm{H}$ NMR spectrum of 3c in $\mathrm{CDCl}_{3}$.

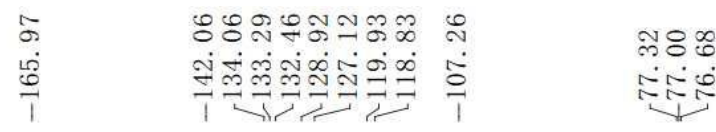

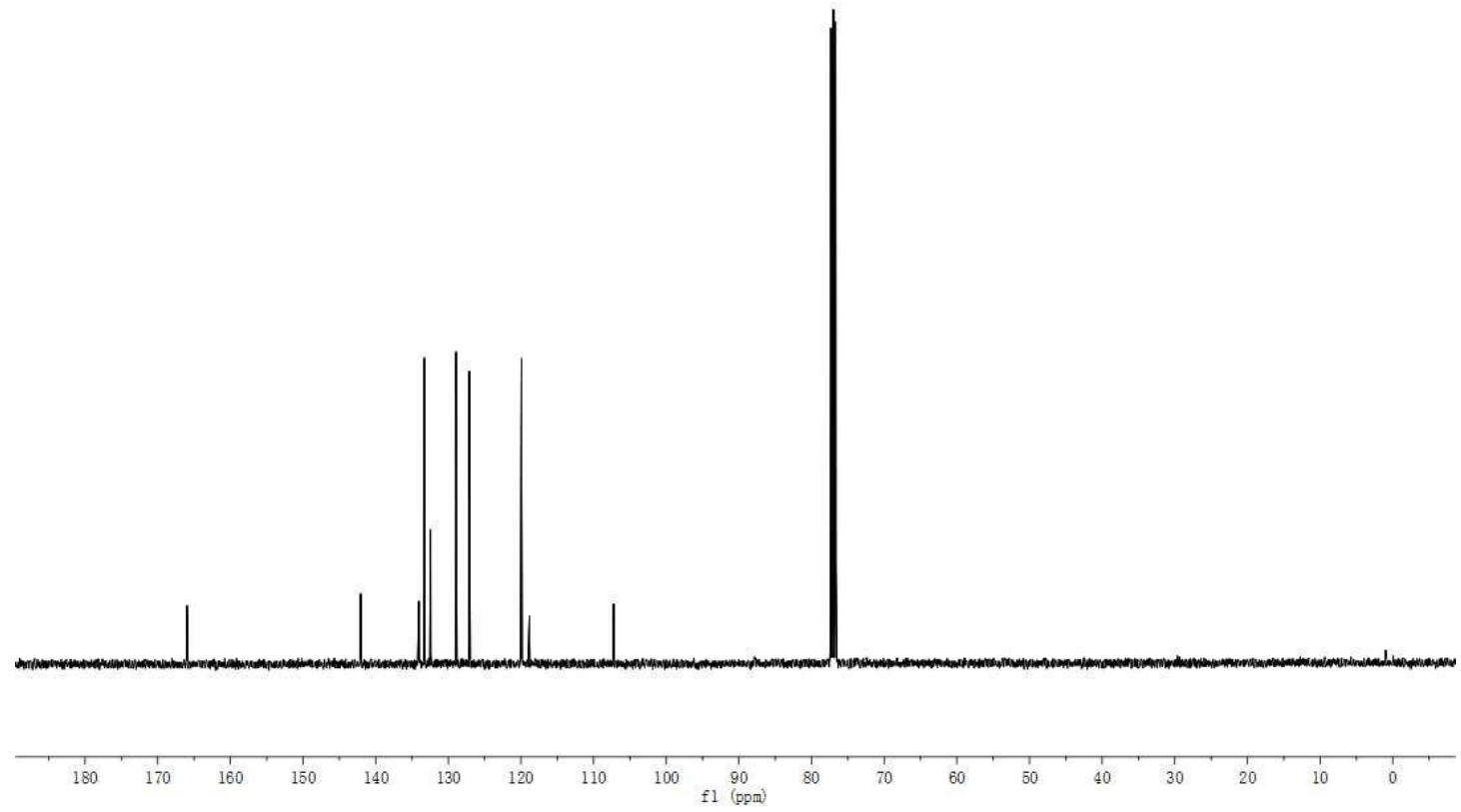

Figure S6. $100 \mathrm{MHz}{ }^{13} \mathrm{C}\left\{{ }^{1} \mathrm{H}\right\} \mathrm{NMR}$ spectrum of $\mathbf{3 c}$ in $\mathrm{CDCl}_{3}$. 
<smiles>Cc1ccc(NC(=O)c2ccccc2)cc1C#N</smiles>

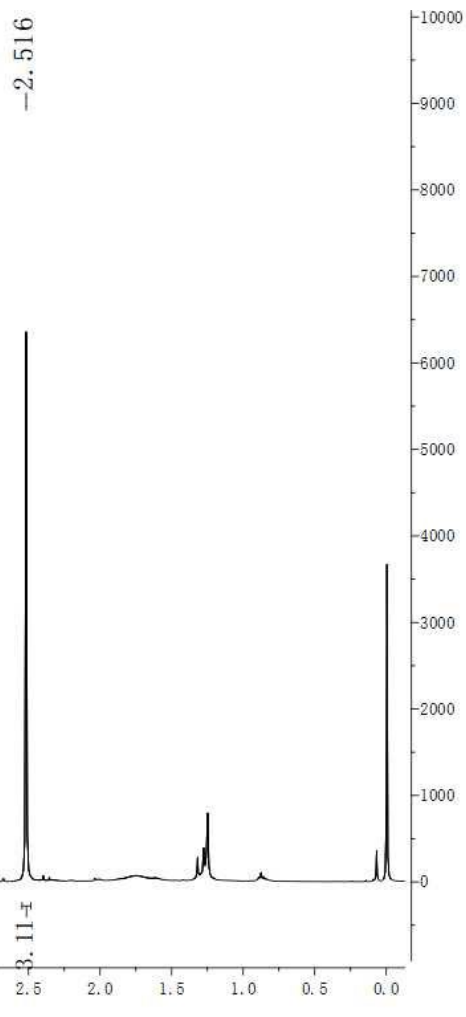

Figure S7. $400 \mathrm{MHz}{ }^{1} \mathrm{H}$ NMR spectrum of $\mathbf{3 d}$ in $\mathrm{CDCl}_{3}$.

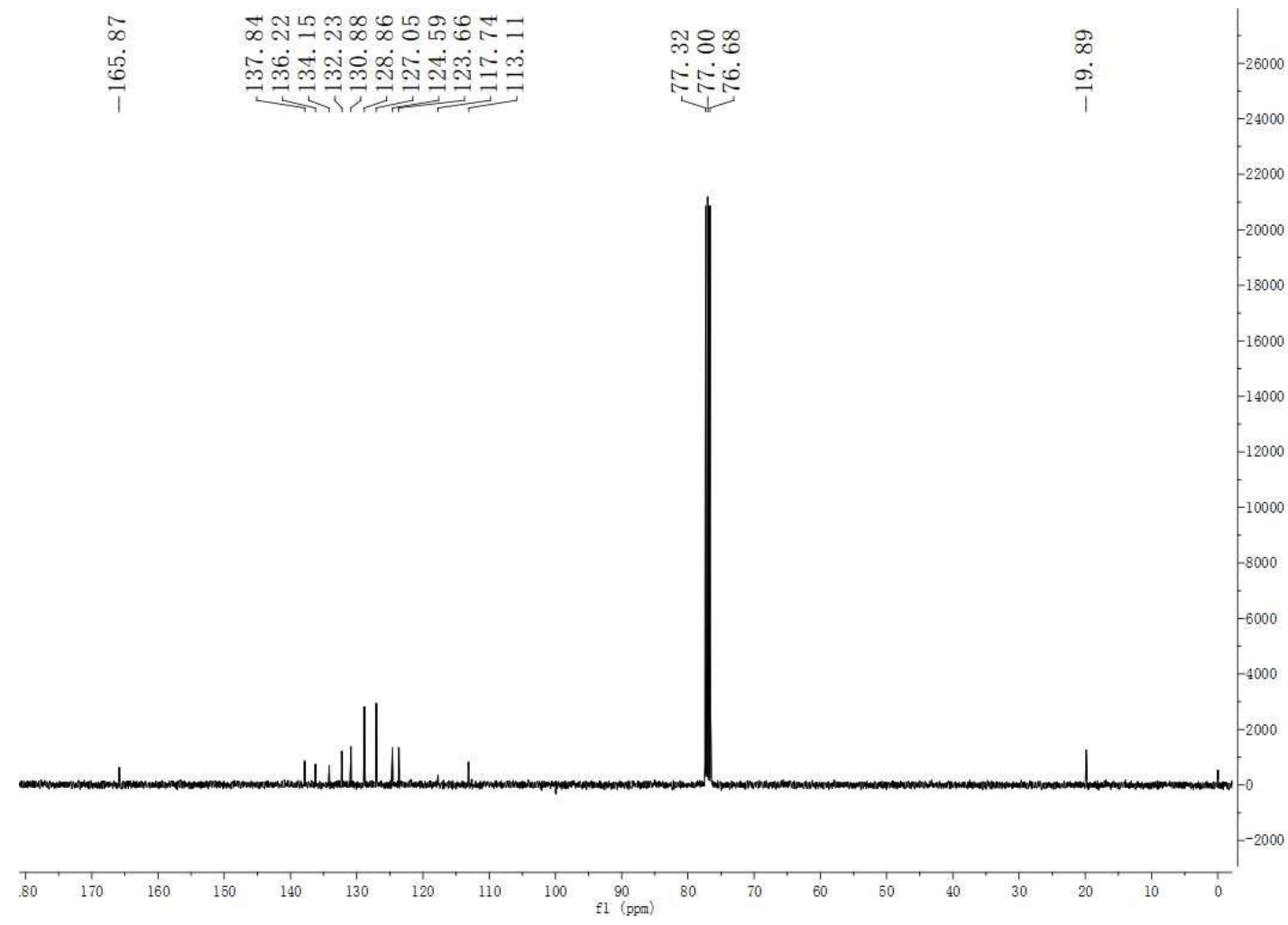

Figure S8. $100 \mathrm{MHz}{ }^{13} \mathrm{C}\left\{{ }^{1} \mathrm{H}\right\} \mathrm{NMR}$ spectrum of $\mathbf{3 d}$ in $\mathrm{CDCl}_{3}$. 


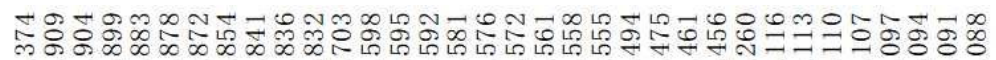

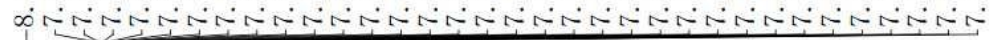<smiles>N#Cc1cc(F)cc(NC(=O)c2ccccc2)c1</smiles>

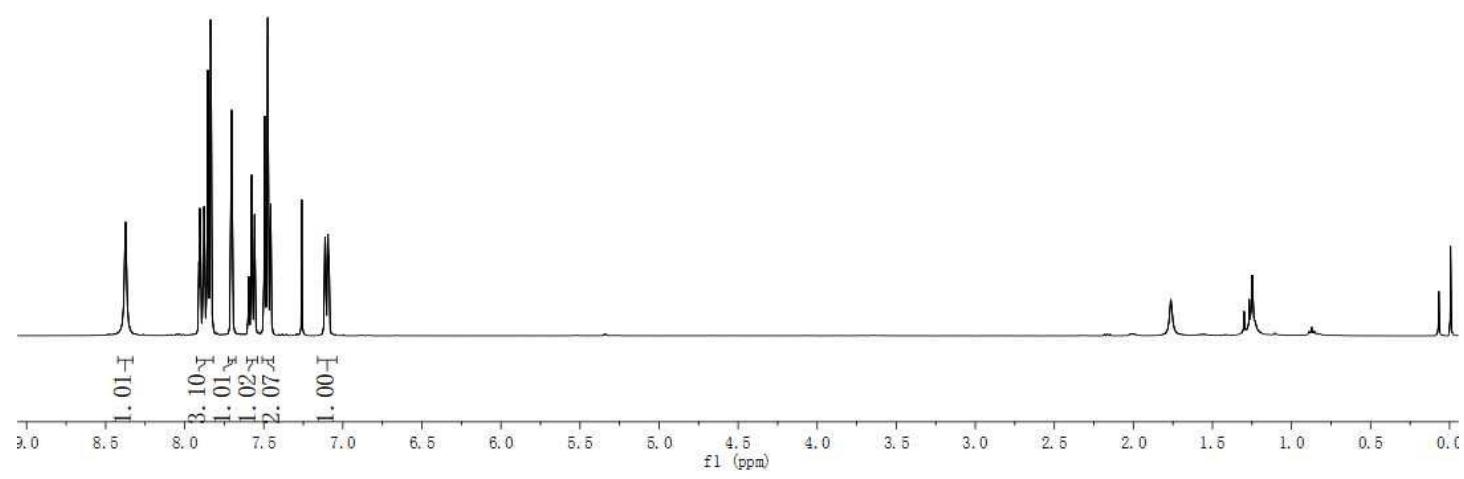

Figure S9. $400 \mathrm{MHz}{ }^{1} \mathrm{H}$ NMR spectrum of $3 \mathbf{e}$ in $\mathrm{CDCl}_{3}$.

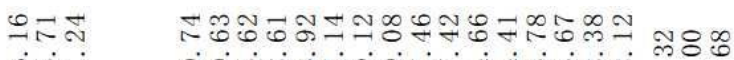

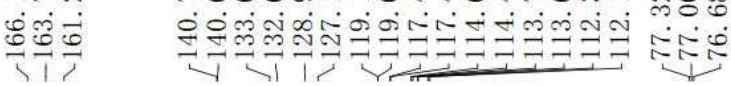

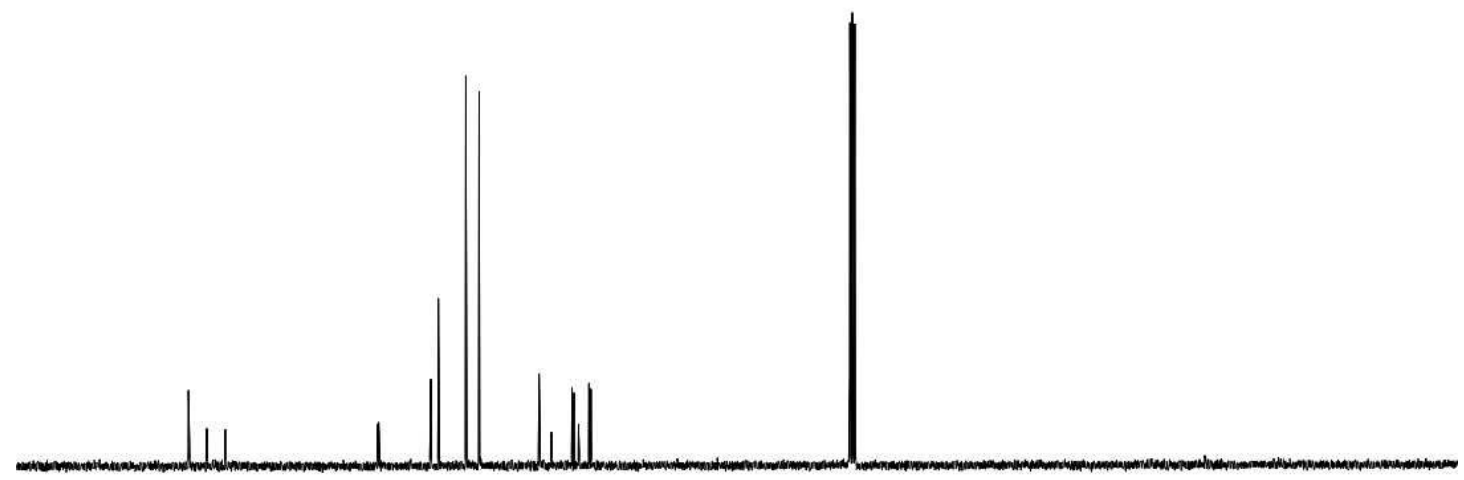

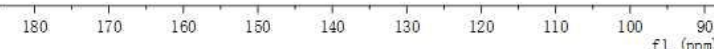

Figure S10. $100 \mathrm{MHz}{ }^{13} \mathrm{C}\left\{{ }^{1} \mathrm{H}\right\}$ NMR spectrum of $\mathbf{3 e}$ in $\mathrm{CDCl}_{3}$. 


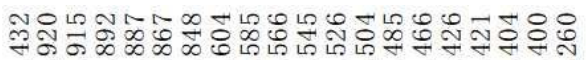

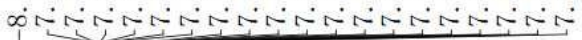
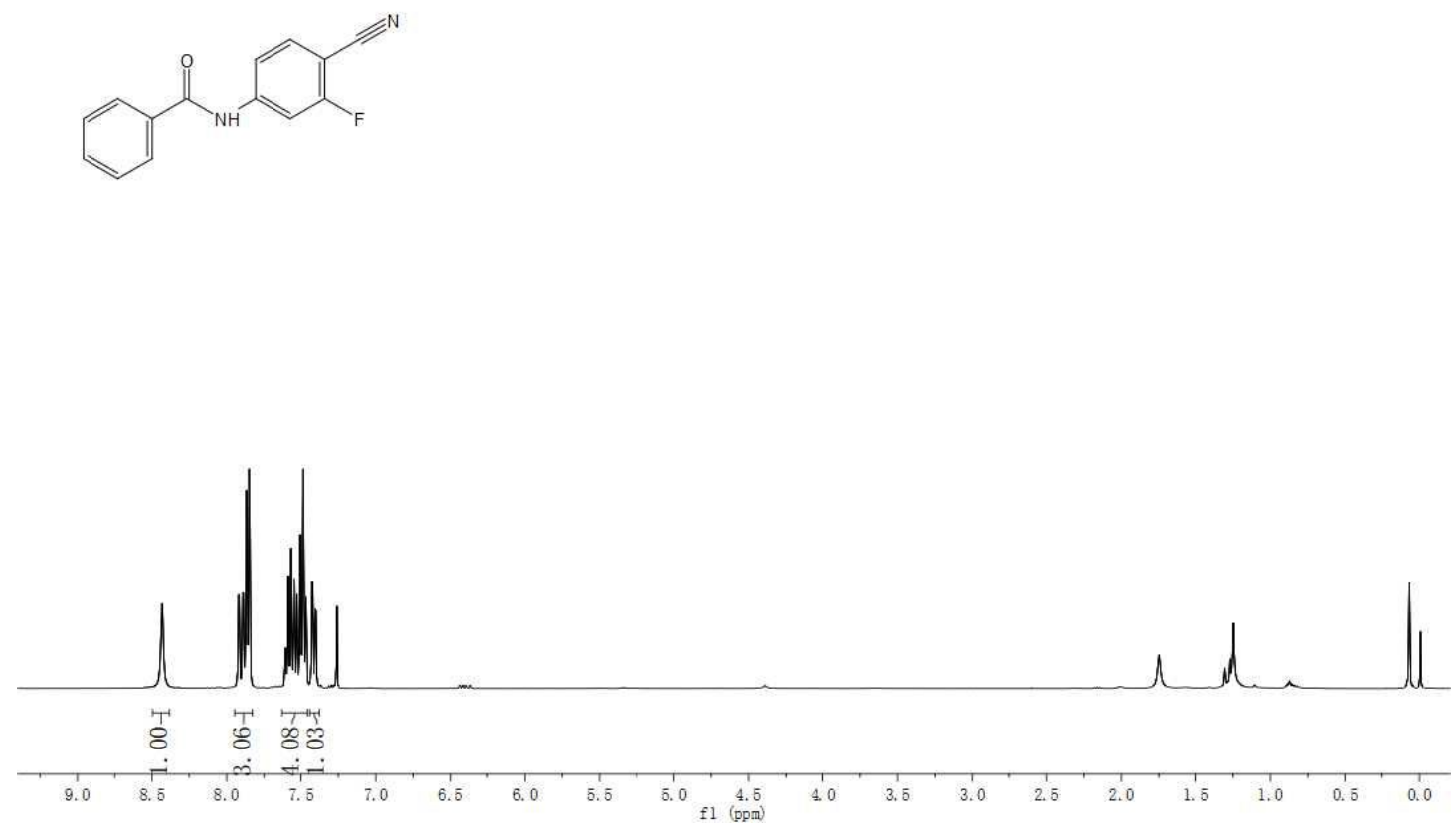

Figure S11. $400 \mathrm{MHz}{ }^{1} \mathrm{H}$ NMR spectrum of $\mathbf{3 f}$ in $\mathrm{CDCl}_{3}$.

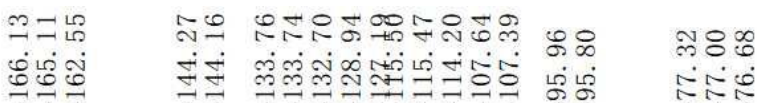

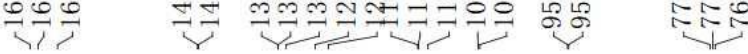
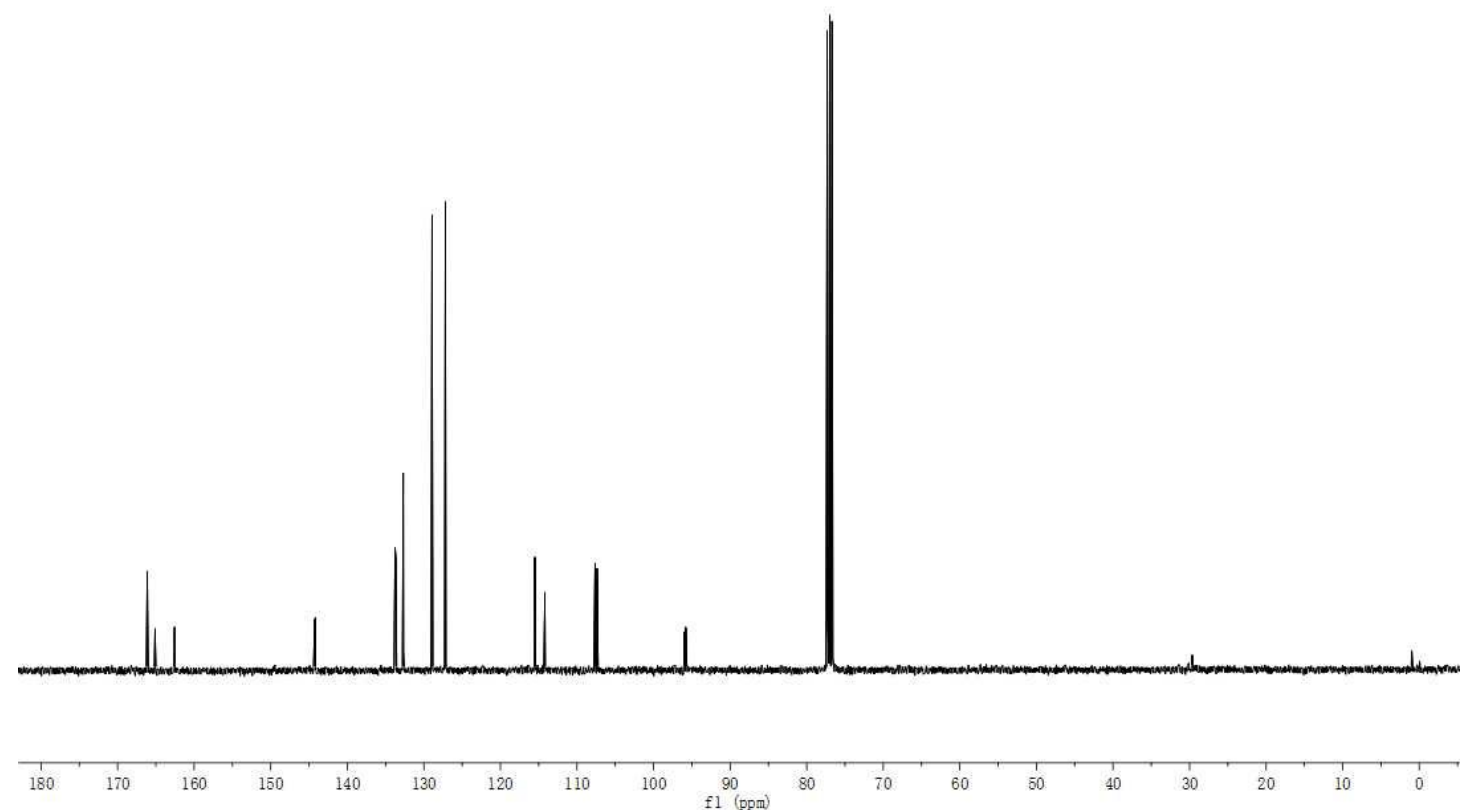

Figure S12. $100 \mathrm{MHz}{ }^{13} \mathrm{C}\left\{{ }^{1} \mathrm{H}\right\}$ NMR spectrum of $\mathbf{3 f}$ in $\mathrm{CDCl}_{3}$. 

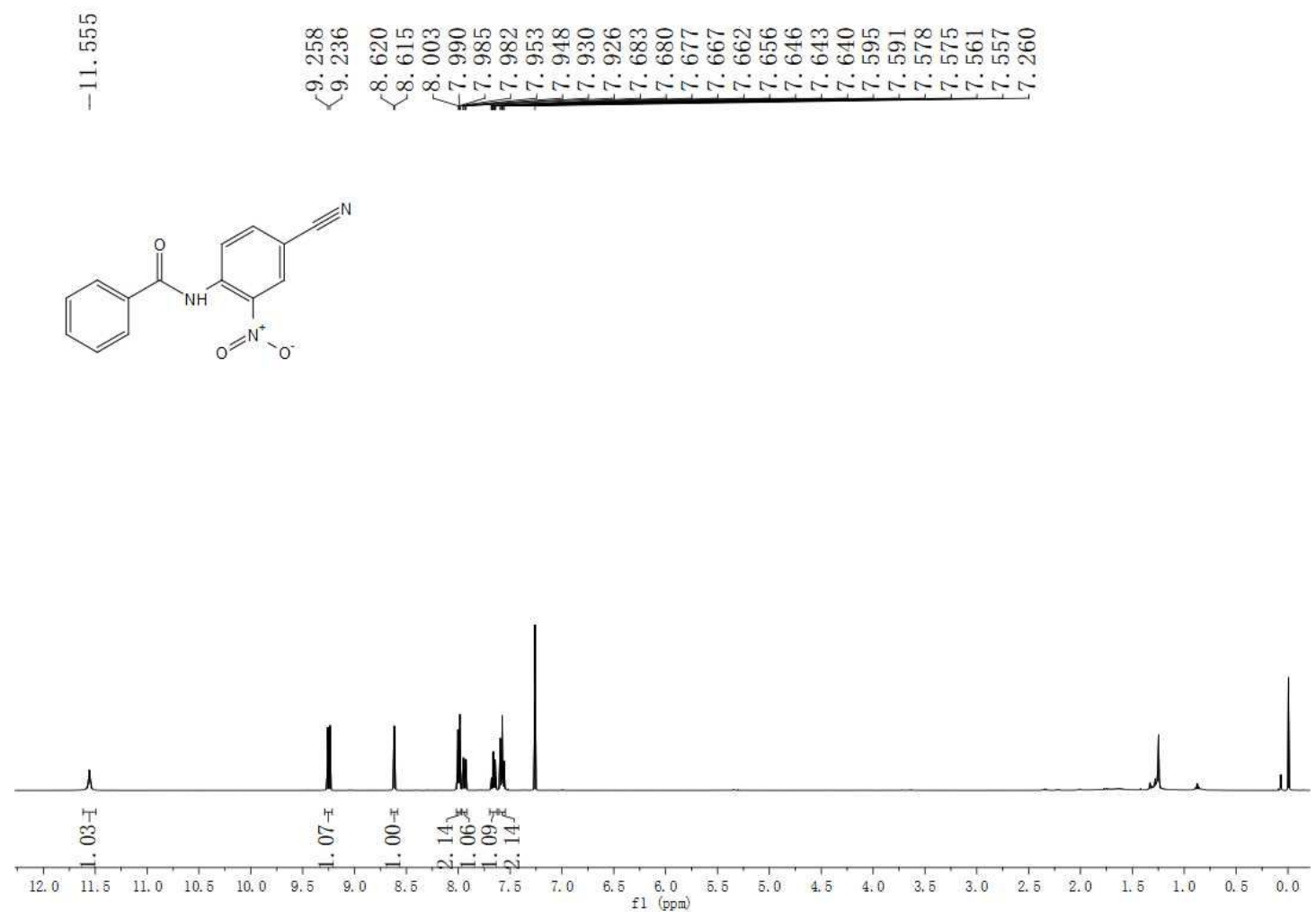

Figure S13. $400 \mathrm{MHz}{ }^{1} \mathrm{H} \mathrm{NMR}$ spectrum of $\mathbf{3 g}$ in $\mathrm{CDCl}_{3}$.

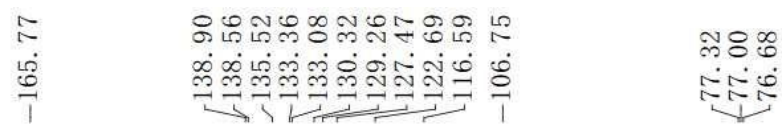

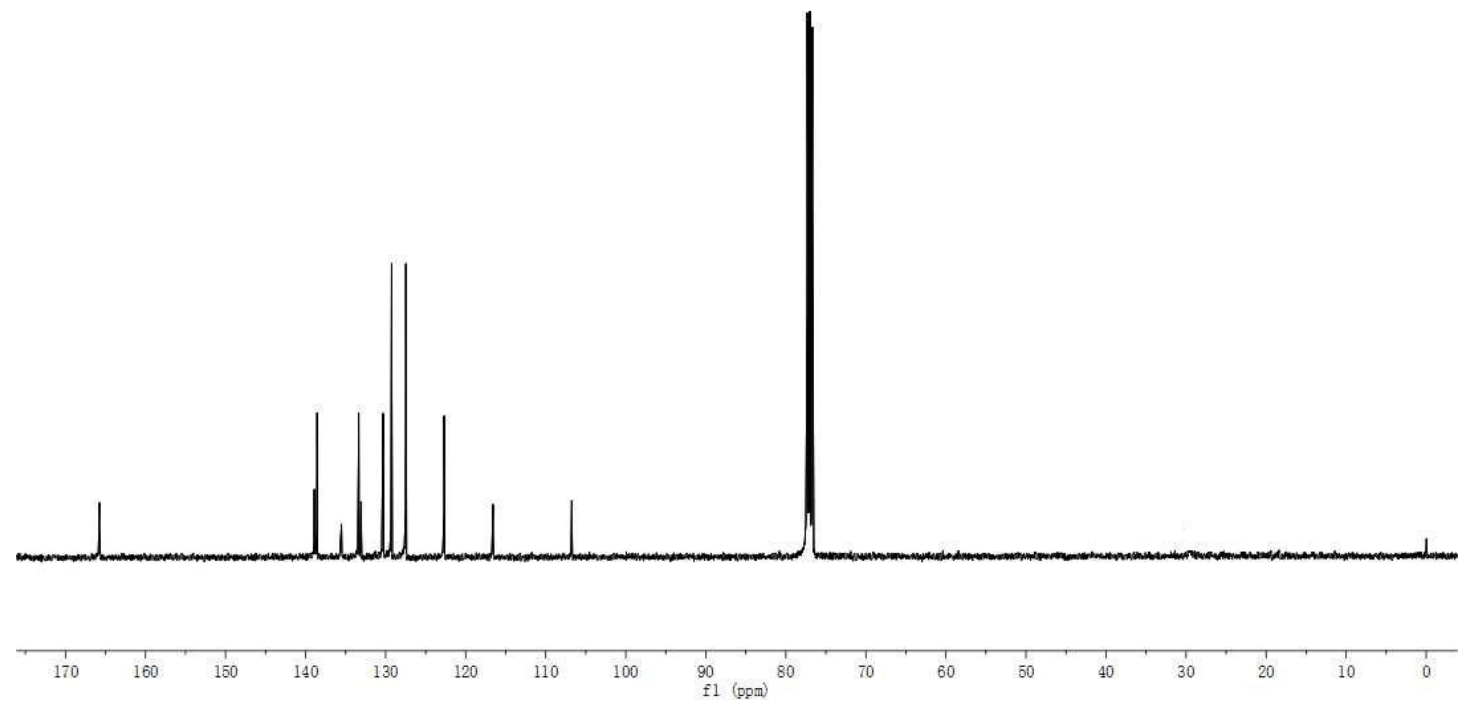

Figure S14. $100 \mathrm{MHz}{ }^{13} \mathrm{C}\left\{{ }^{1} \mathrm{H}\right\}$ NMR spectrum of $\mathbf{3 g}$ in $\mathrm{CDCl}_{3}$. 

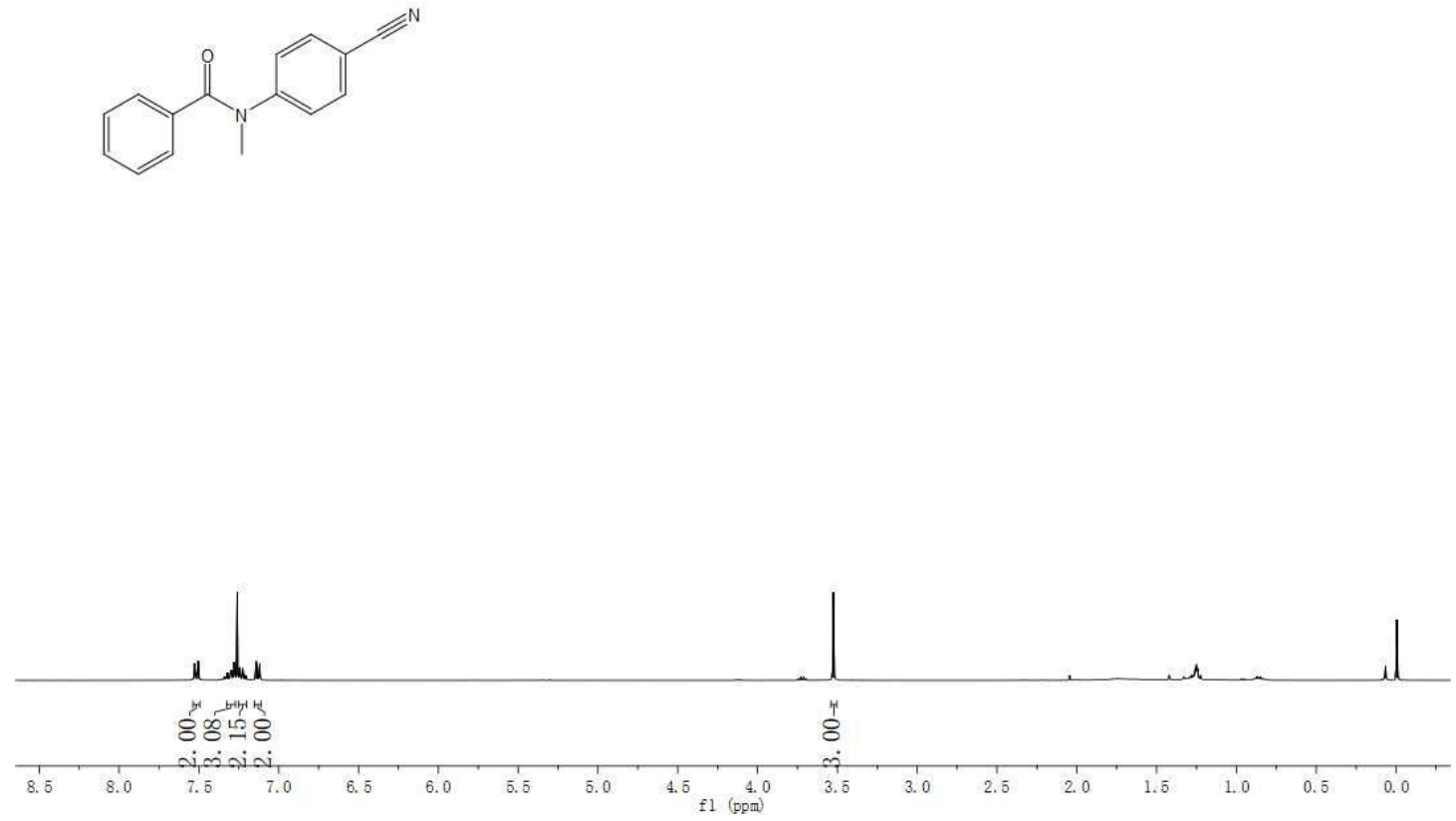

Figure S15. $400 \mathrm{MHz}{ }^{1} \mathrm{H}$ NMR spectrum of $\mathbf{3 h}$ in $\mathrm{CDCl}_{3}$.

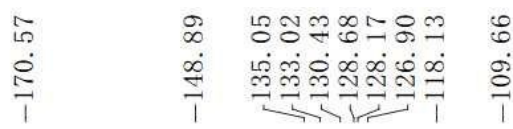
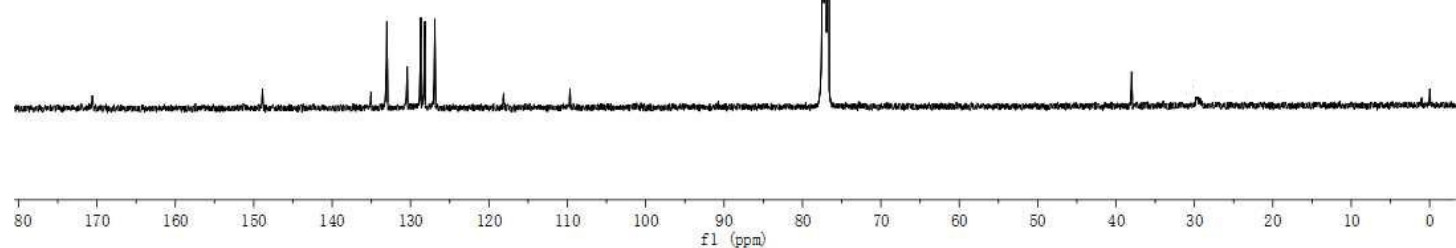

Figure S16. $100 \mathrm{MHz}{ }^{13} \mathrm{C}\left\{{ }^{1} \mathrm{H}\right\}$ NMR spectrum of $\mathbf{3 h}$ in $\mathrm{CDCl}_{3}$. 

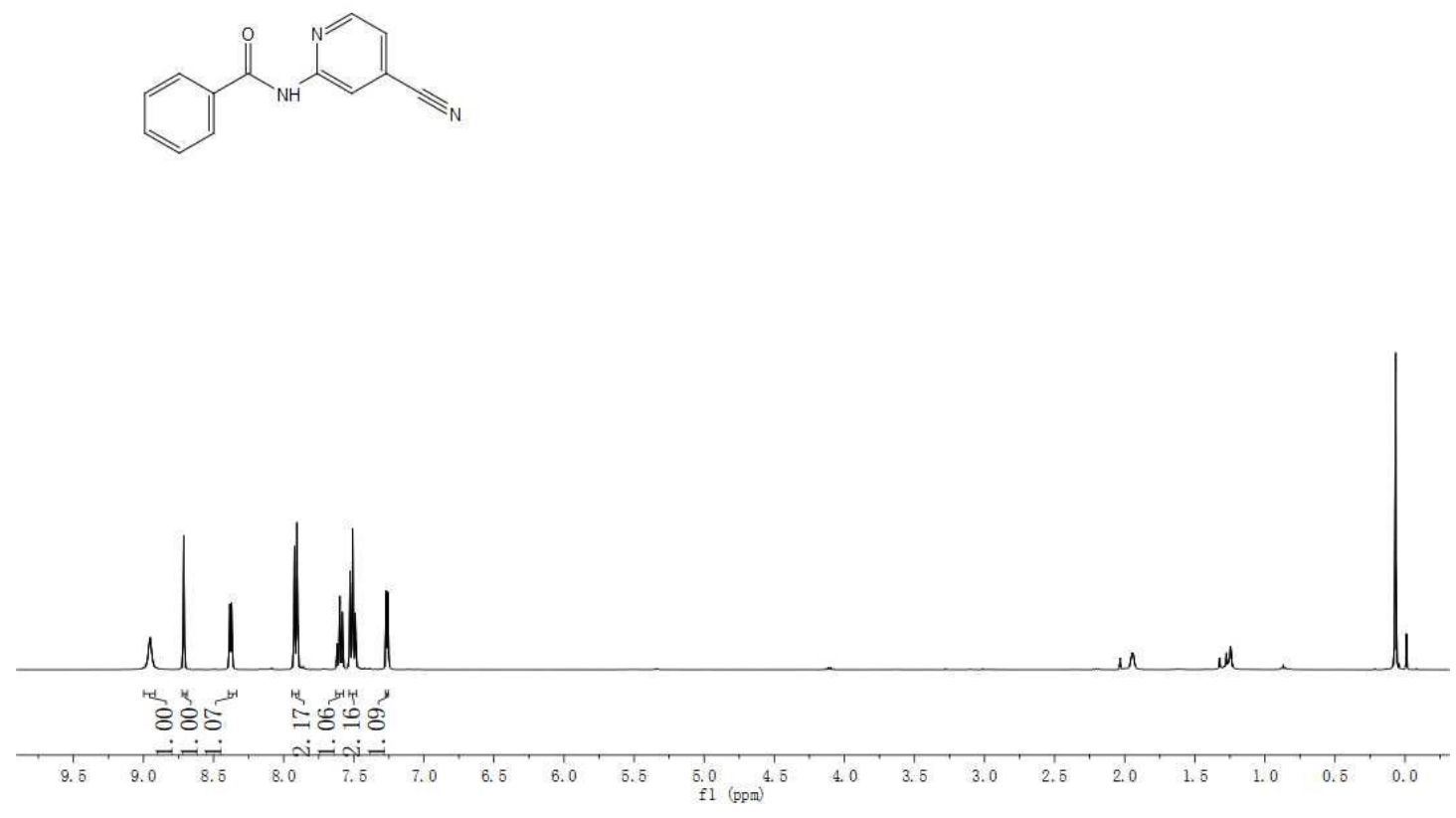

Figure S17. $400 \mathrm{MHz}{ }^{1} \mathrm{H}$ NMR spectrum of $3 \mathbf{i}$ in $\mathrm{CDCl}_{3}$.

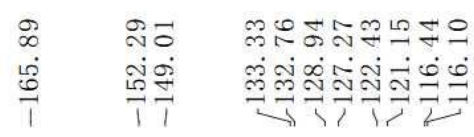

\section{กิะ $8:$}

N芯
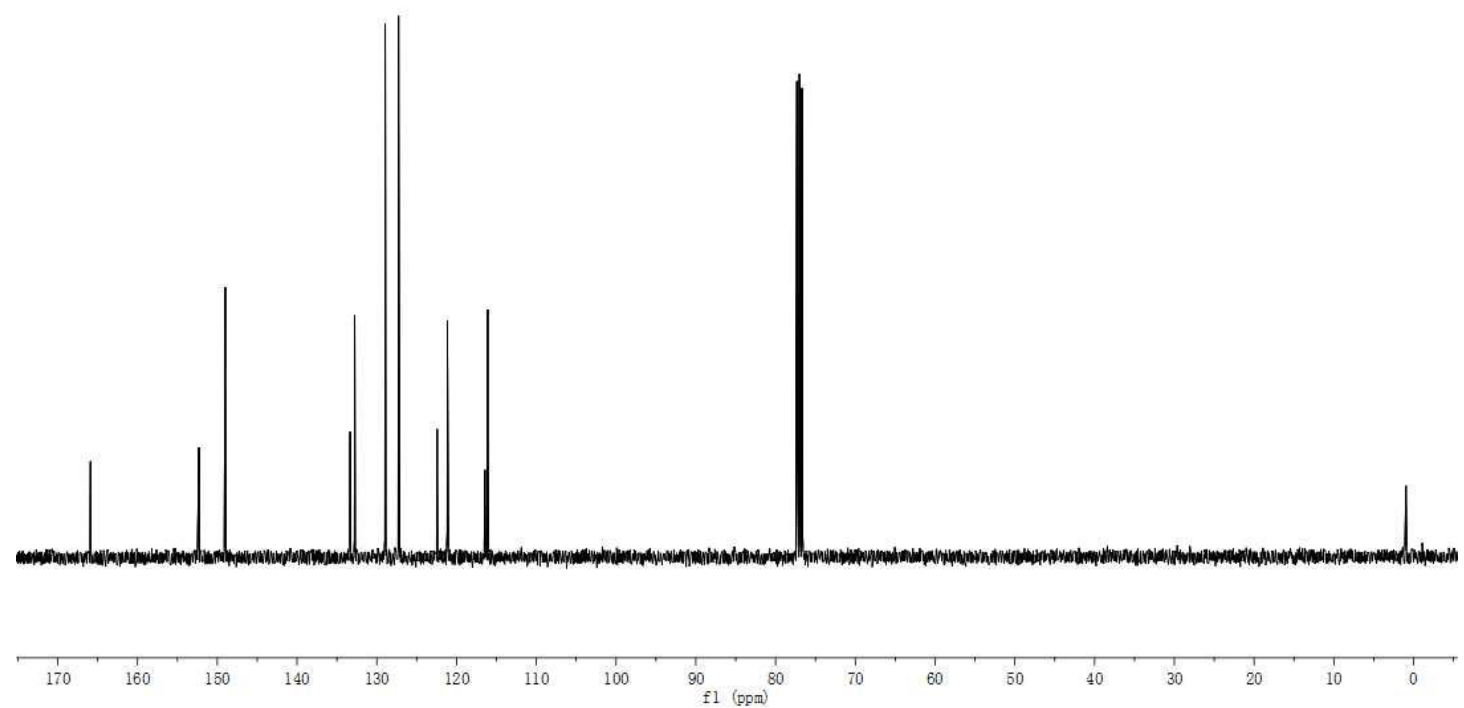

Figure S18. $100 \mathrm{MHz}{ }^{13} \mathrm{C}\left\{{ }^{1} \mathrm{H}\right\} \mathrm{NMR}$ spectrum of $\mathbf{3 i}$ in $\mathrm{CDCl}_{3}$. 
œ

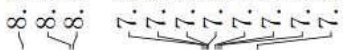
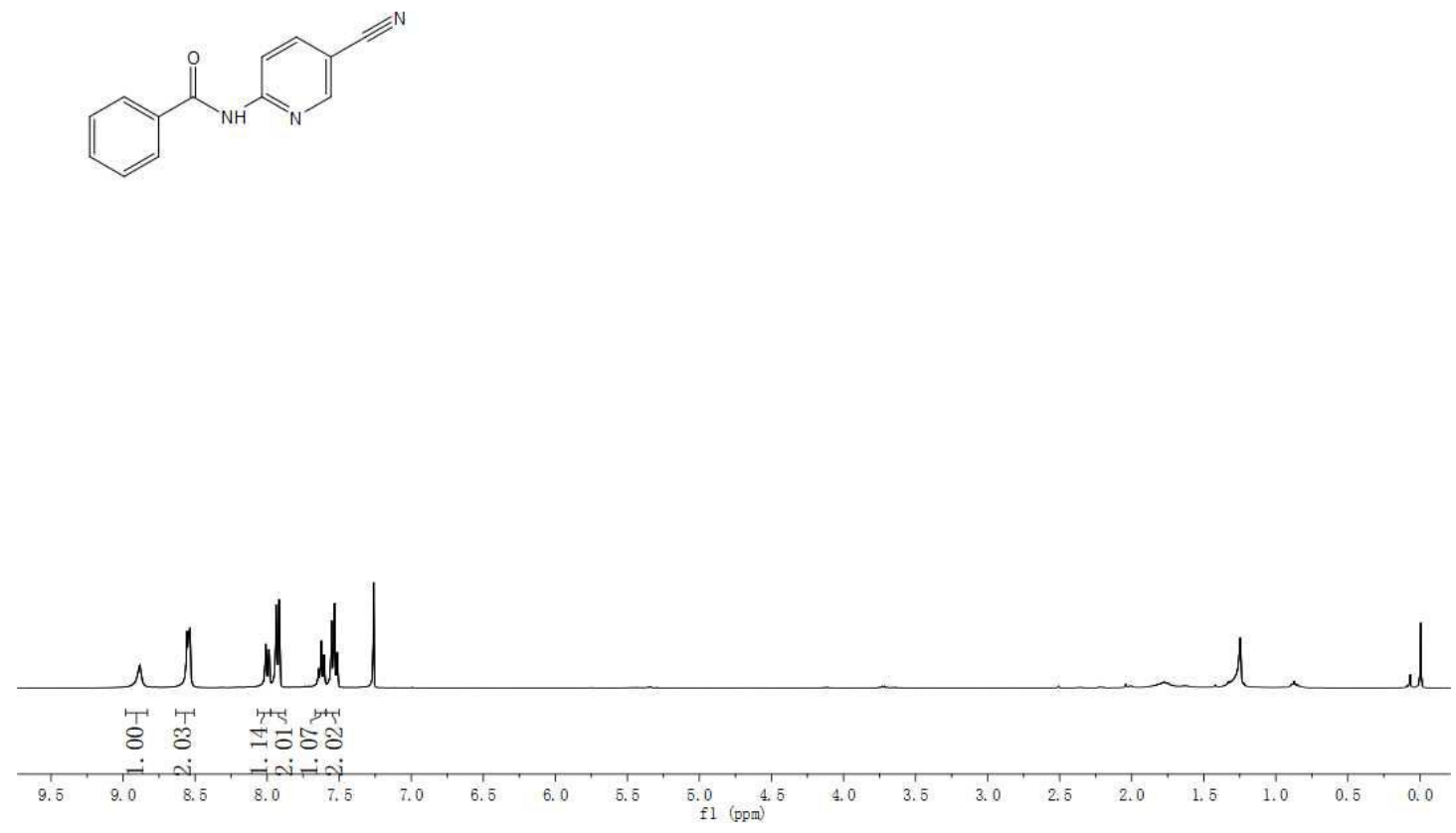

Figure S19. $400 \mathrm{MHz}{ }^{1} \mathrm{H}$ NMR spectrum of $\mathbf{3 j}$ in $\mathrm{CDCl}_{3}$.

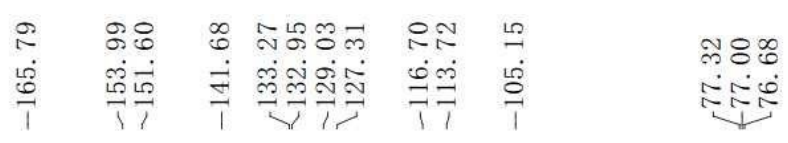

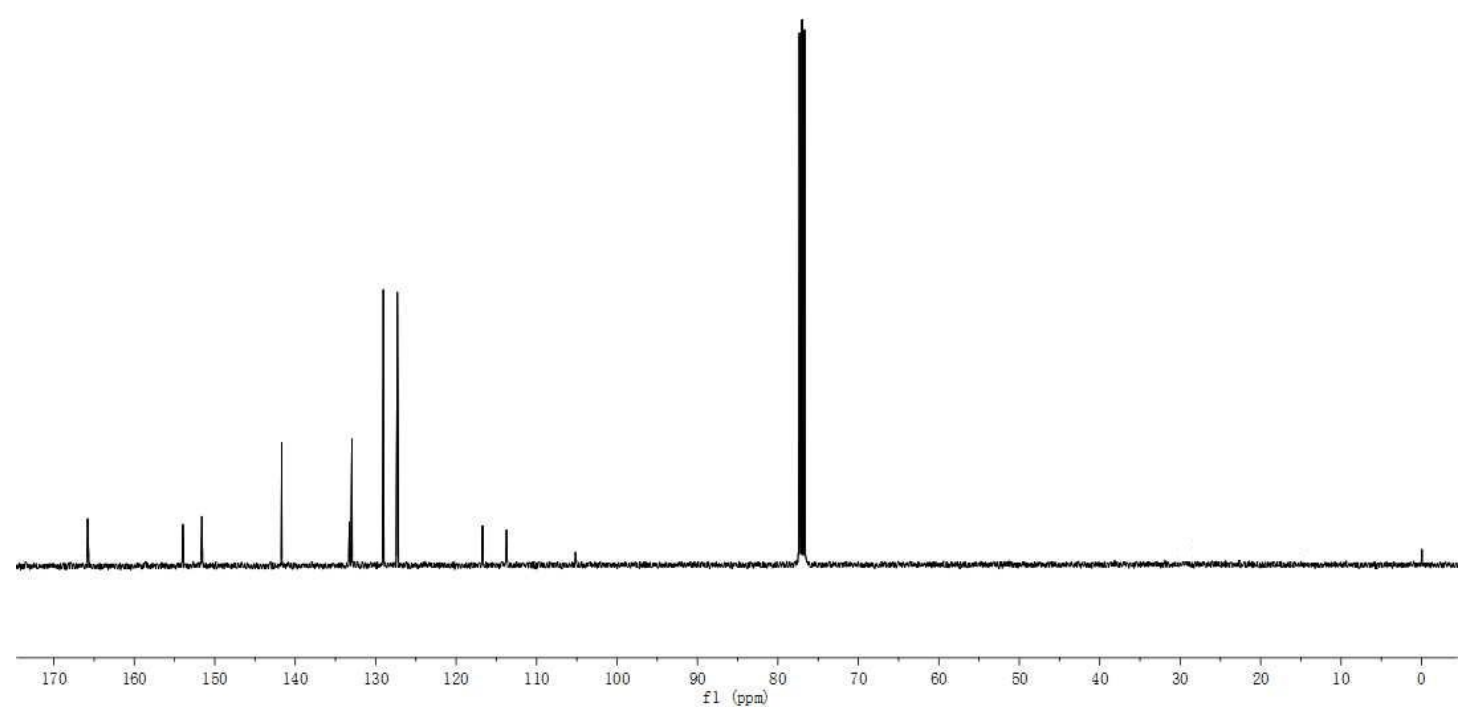

Figure S20. $100 \mathrm{MHz}{ }^{13} \mathrm{C}\left\{{ }^{1} \mathrm{H}\right\}$ NMR spectrum of $\mathbf{3 j}$ in $\mathrm{CDCl}_{3}$. 


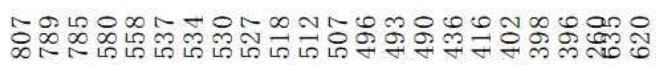

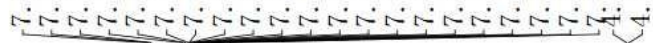<smiles>N#Cc1cccc(CNC(=O)c2ccccc2)c1</smiles>

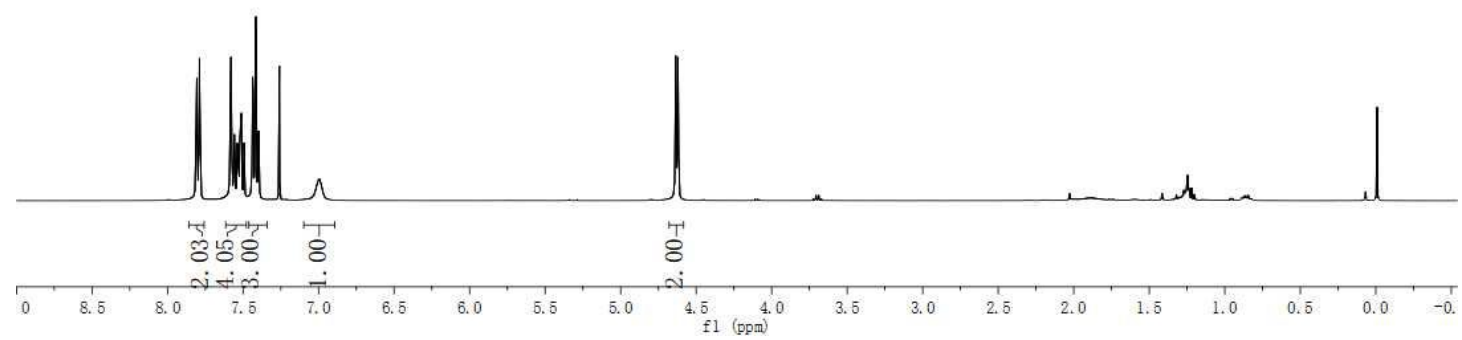

Figure S21. $400 \mathrm{MHz}{ }^{1} \mathrm{H}$ NMR spectrum of $\mathbf{3 k}$ in $\mathrm{CDCl}_{3}$.

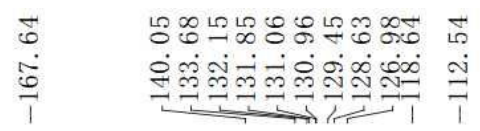

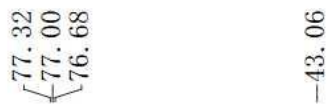

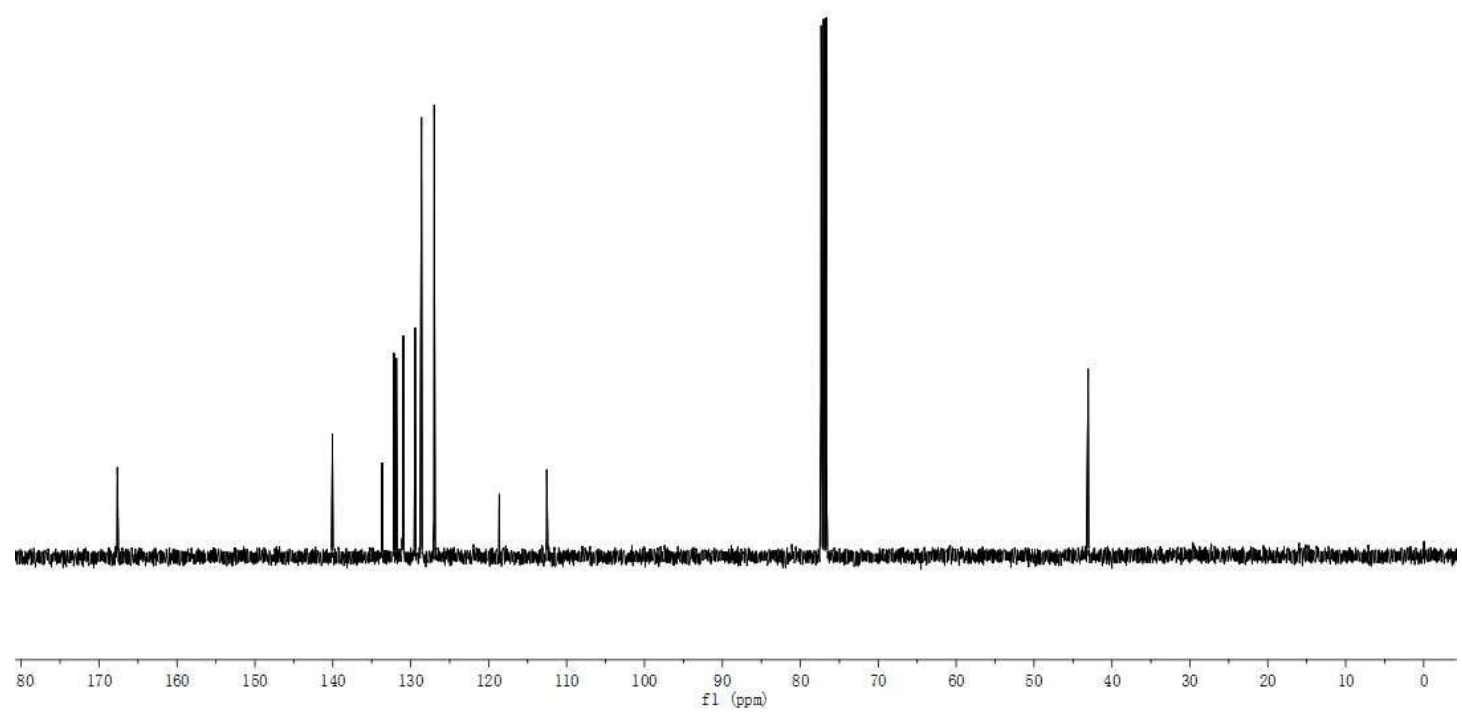

Figure S22. $100 \mathrm{MHz}{ }^{13} \mathrm{C}\left\{{ }^{1} \mathrm{H}\right\}$ NMR spectrum of 3k in $\mathrm{CDCl}_{3}$. 

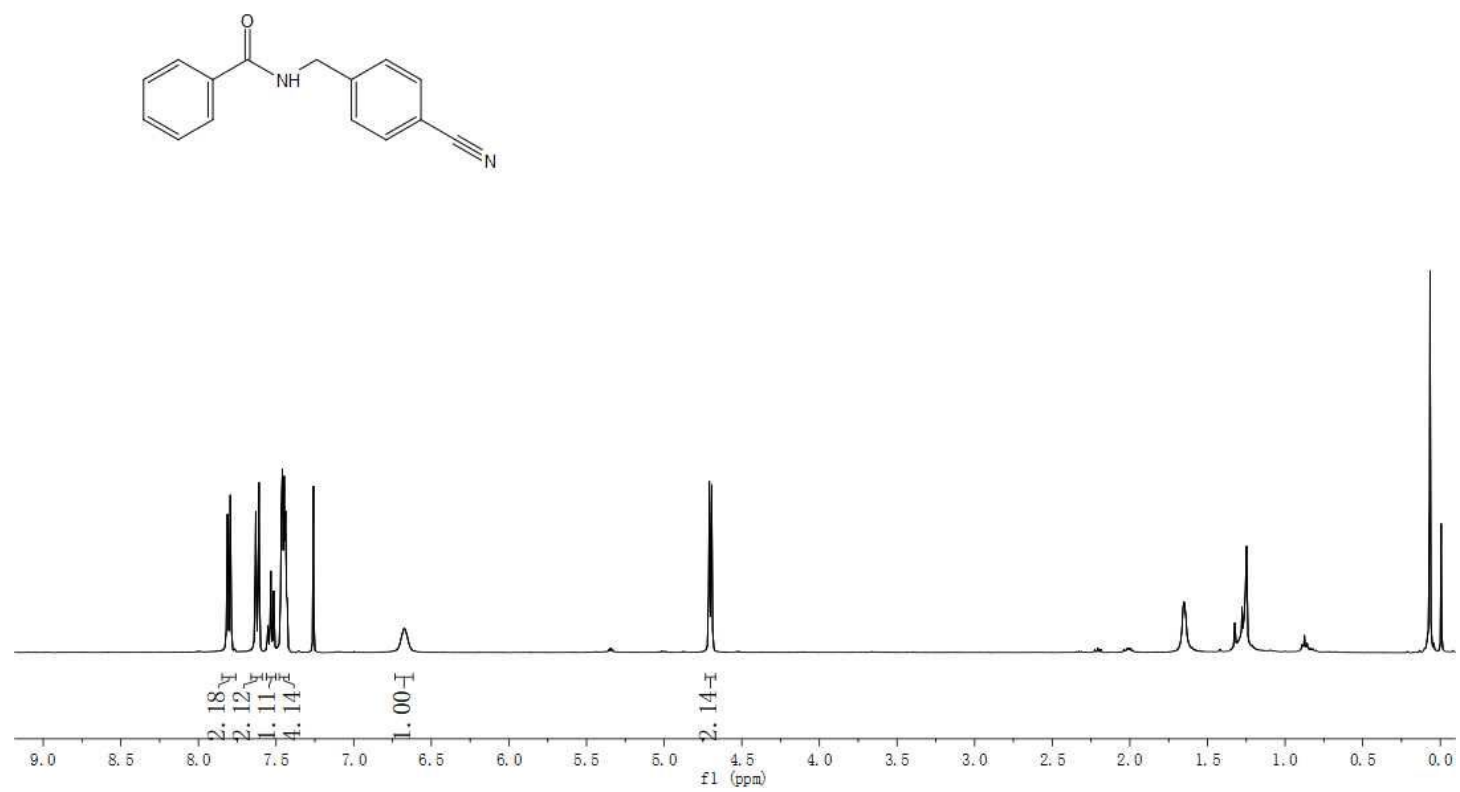

Figure S23. $400 \mathrm{MHz}{ }^{1} \mathrm{H}$ NMR spectrum of $\mathbf{3 1}$ in $\mathrm{CDCl}_{3}$.

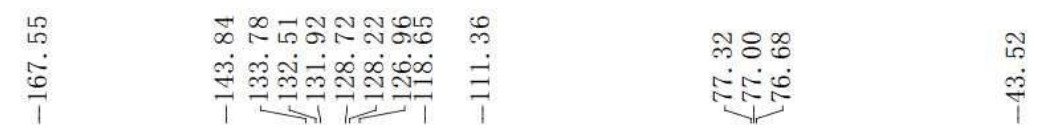
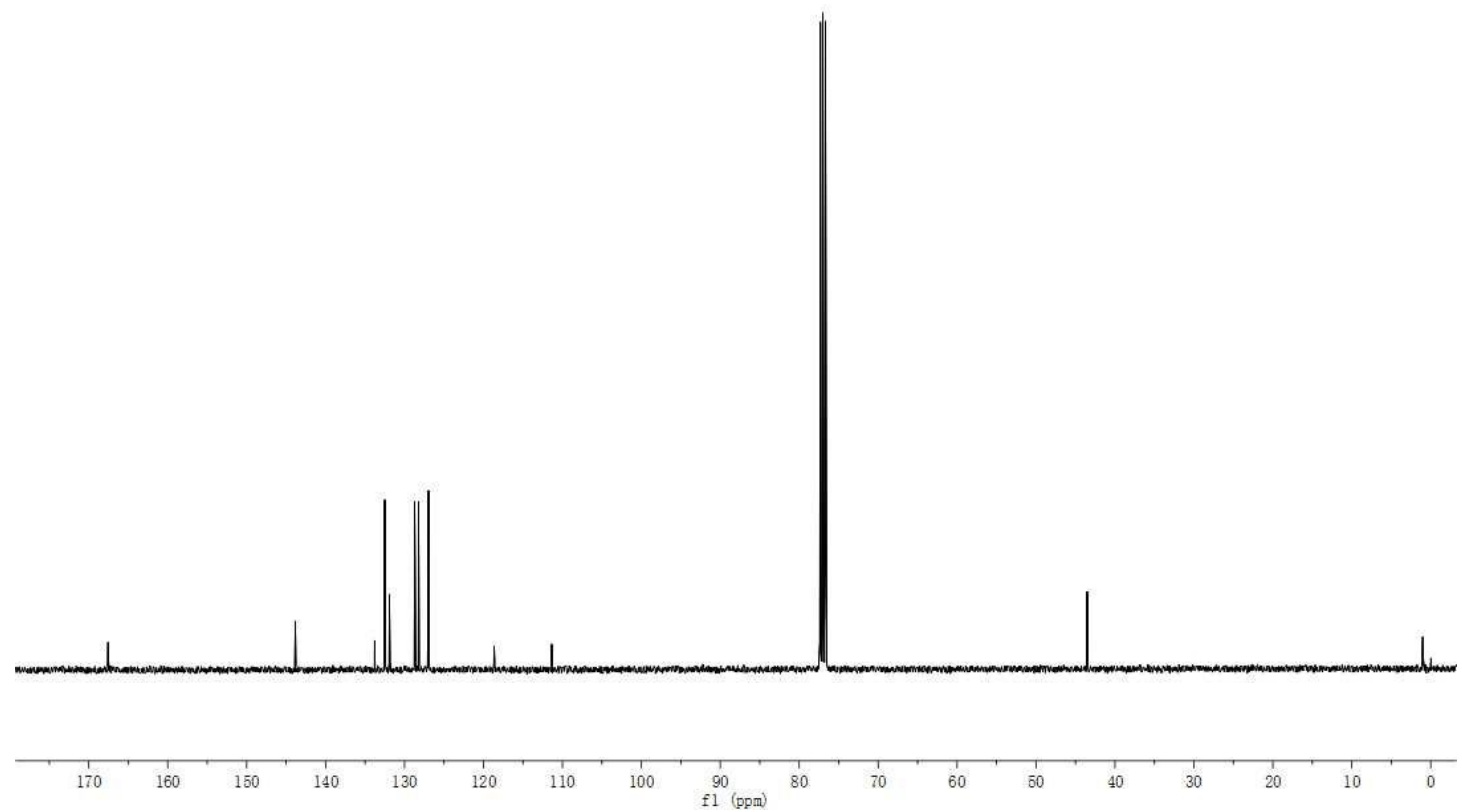

Figure S24. $100 \mathrm{MHz}{ }^{13} \mathrm{C}\left\{{ }^{1} \mathrm{H}\right\} \mathrm{NMR}$ spectrum of $\mathbf{3 l}$ in $\mathrm{CDCl}_{3}$. 
<smiles>Cc1cccc(C(=O)Nc2ccccc2C#N)c1</smiles>

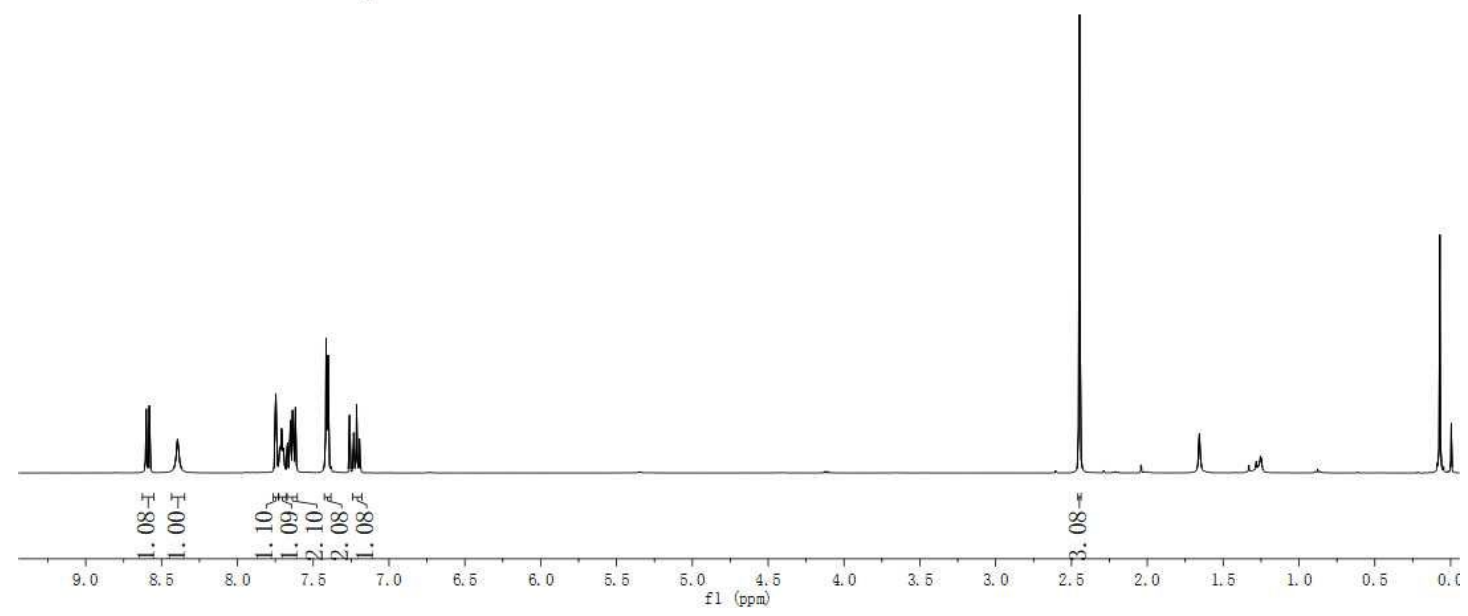

Figure S25. $400 \mathrm{MHz}{ }^{1} \mathrm{H}$ NMR spectrum of $\mathbf{3 m}$ in $\mathrm{CDCl}_{3}$.

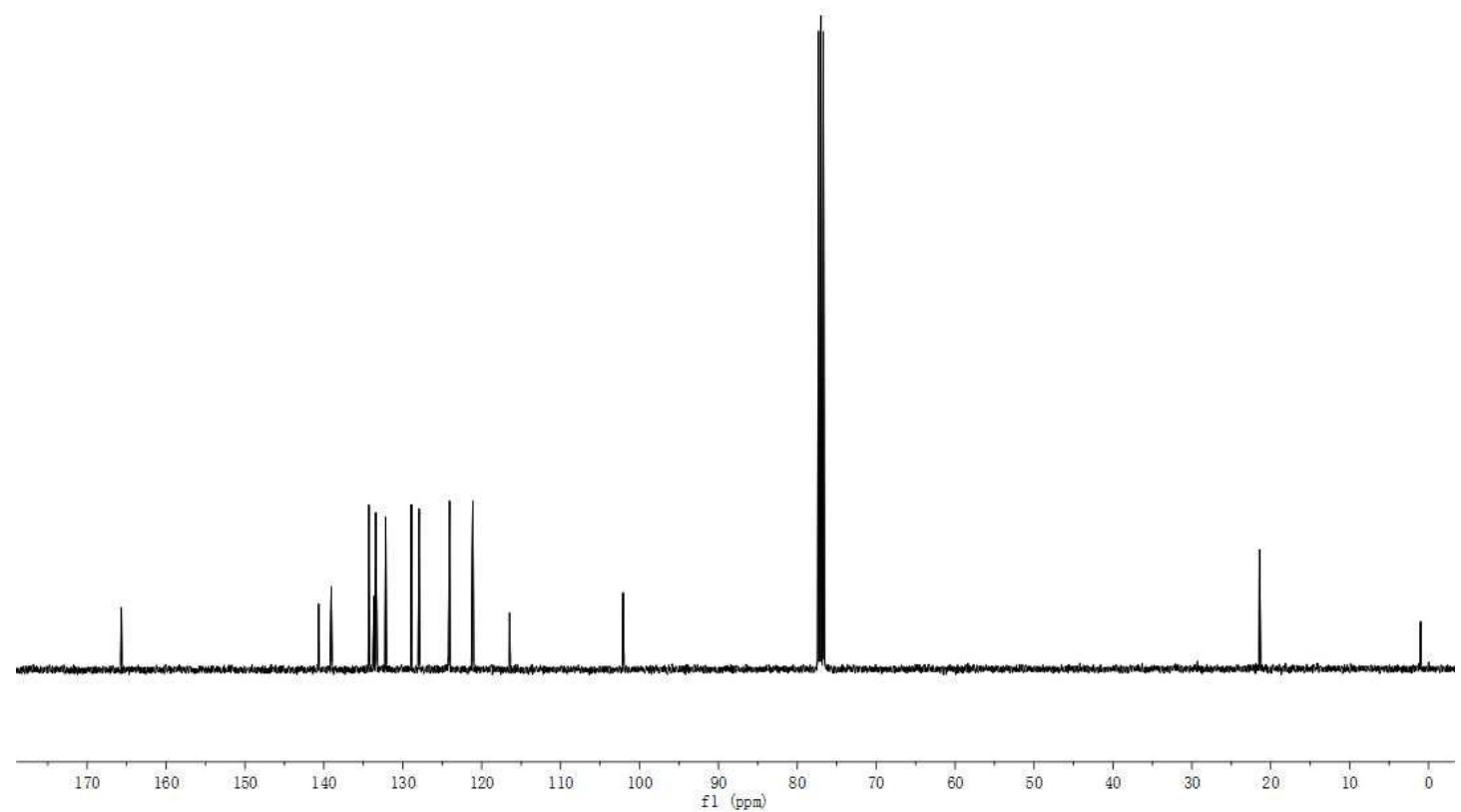

Figure S26. $100 \mathrm{MHz}{ }^{13} \mathrm{C}\left\{{ }^{1} \mathrm{H}\right\}$ NMR spectrum of $\mathbf{3 m}$ in $\mathrm{CDCl}_{3}$. 
<smiles>Cc1cccc(C(=O)NCc2ccc(C#N)cc2)c1</smiles>

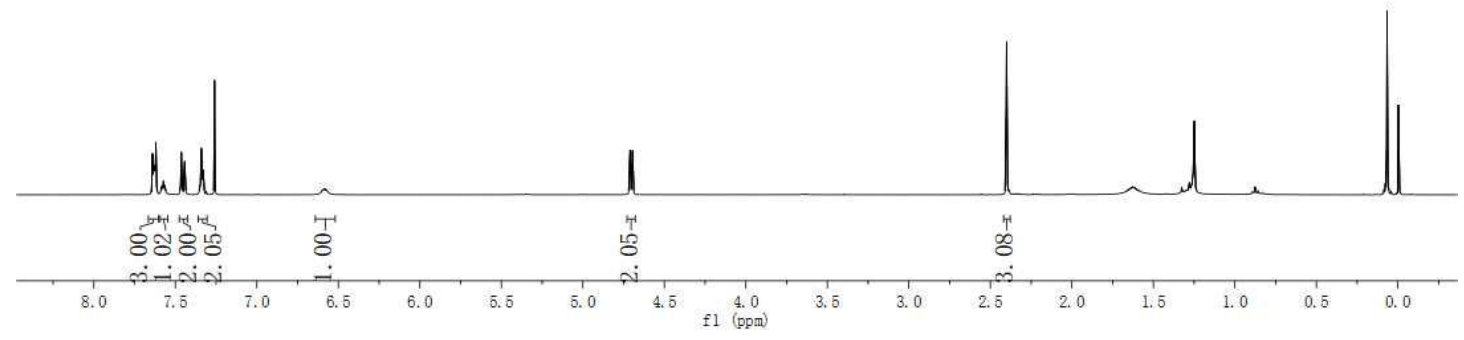

Figure S27. $400 \mathrm{MHz}{ }^{1} \mathrm{H}$ NMR spectrum of $\mathbf{3 n}$ in $\mathrm{CDCl}_{3}$.
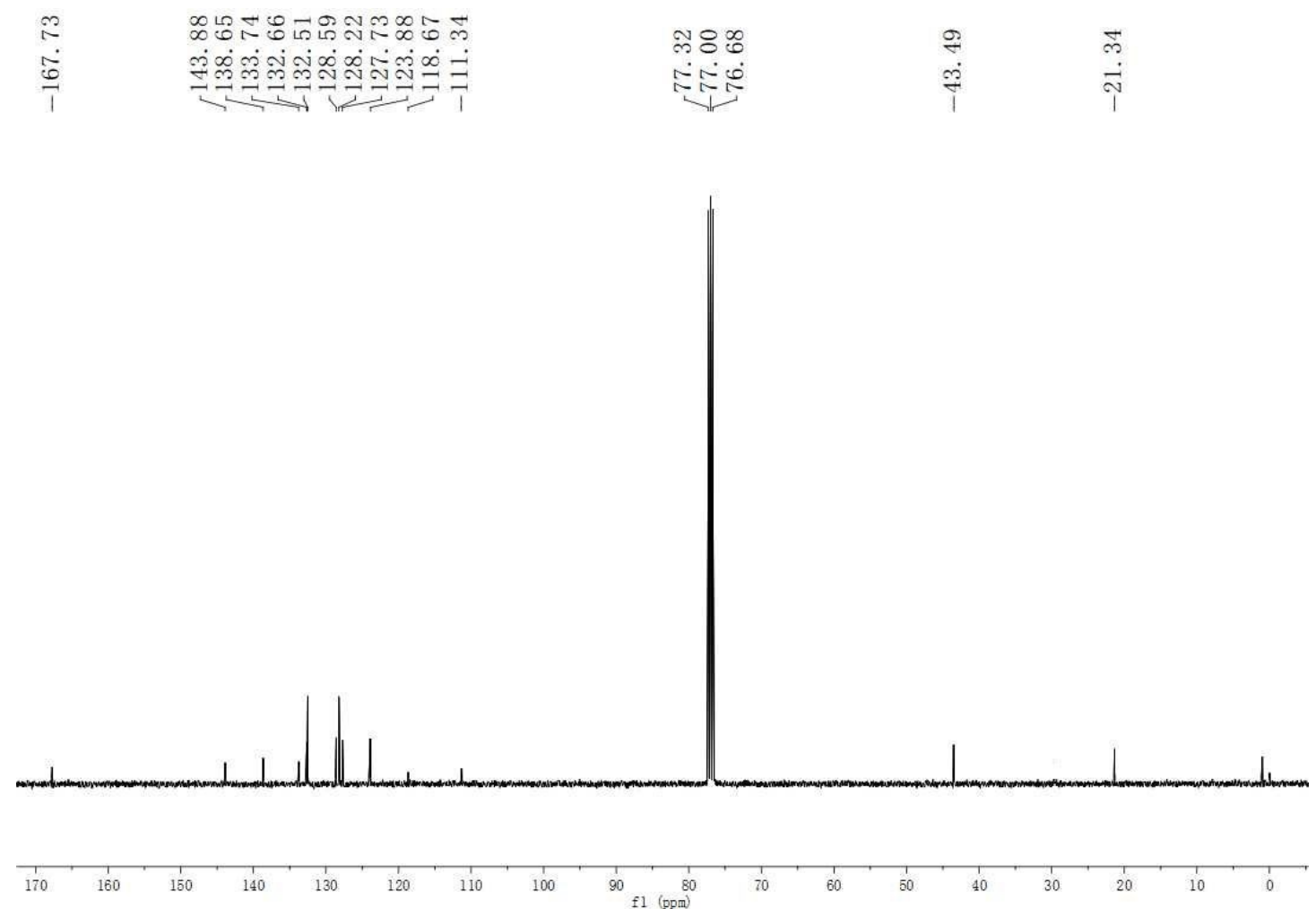

Figure S28. $100 \mathrm{MHz}{ }^{13} \mathrm{C}\left\{{ }^{1} \mathrm{H}\right\}$ NMR spectrum of $\mathbf{3 n}$ in $\mathrm{CDCl}_{3}$. 

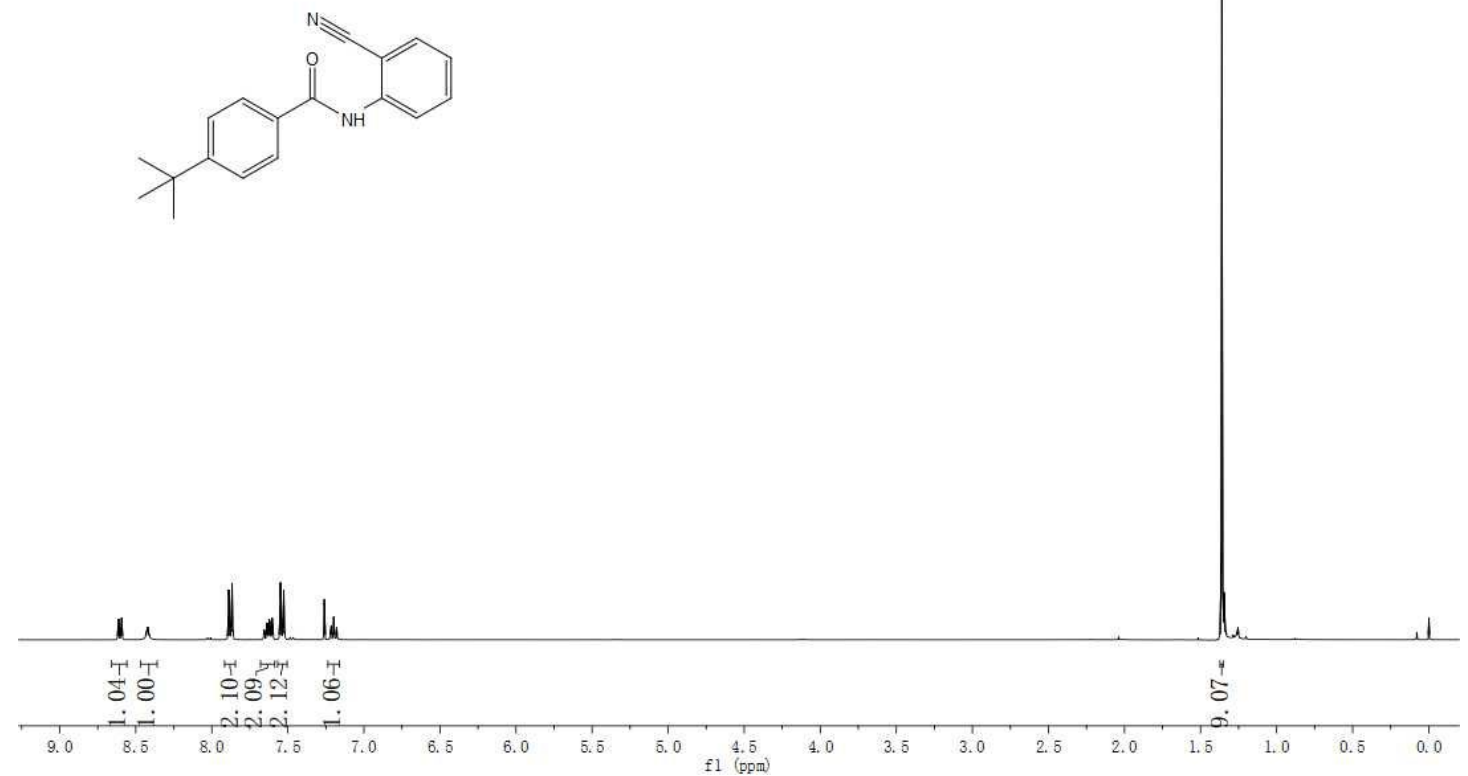

Figure S29. $400 \mathrm{MHz}{ }^{1} \mathrm{H}$ NMR spectrum of 30 in $\mathrm{CDCl}_{3}$.

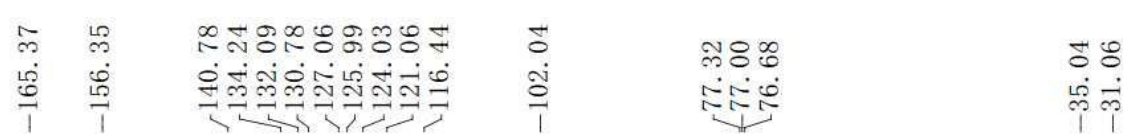
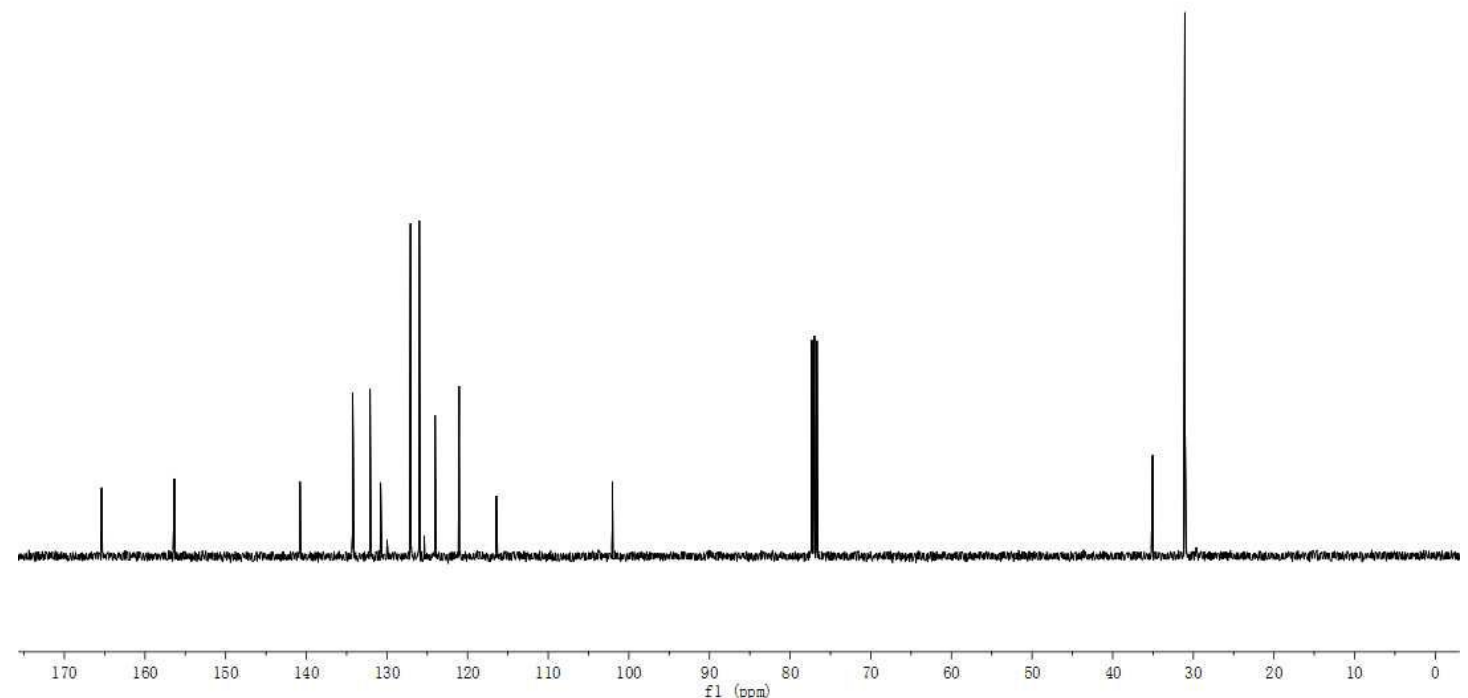

Figure S30. $100 \mathrm{MHz}{ }^{13} \mathrm{C}\left\{{ }^{1} \mathrm{H}\right\}$ NMR spectrum of 3o in $\mathrm{CDCl}_{3}$. 


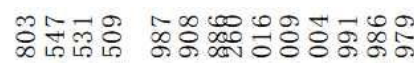

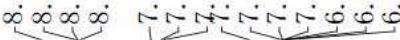
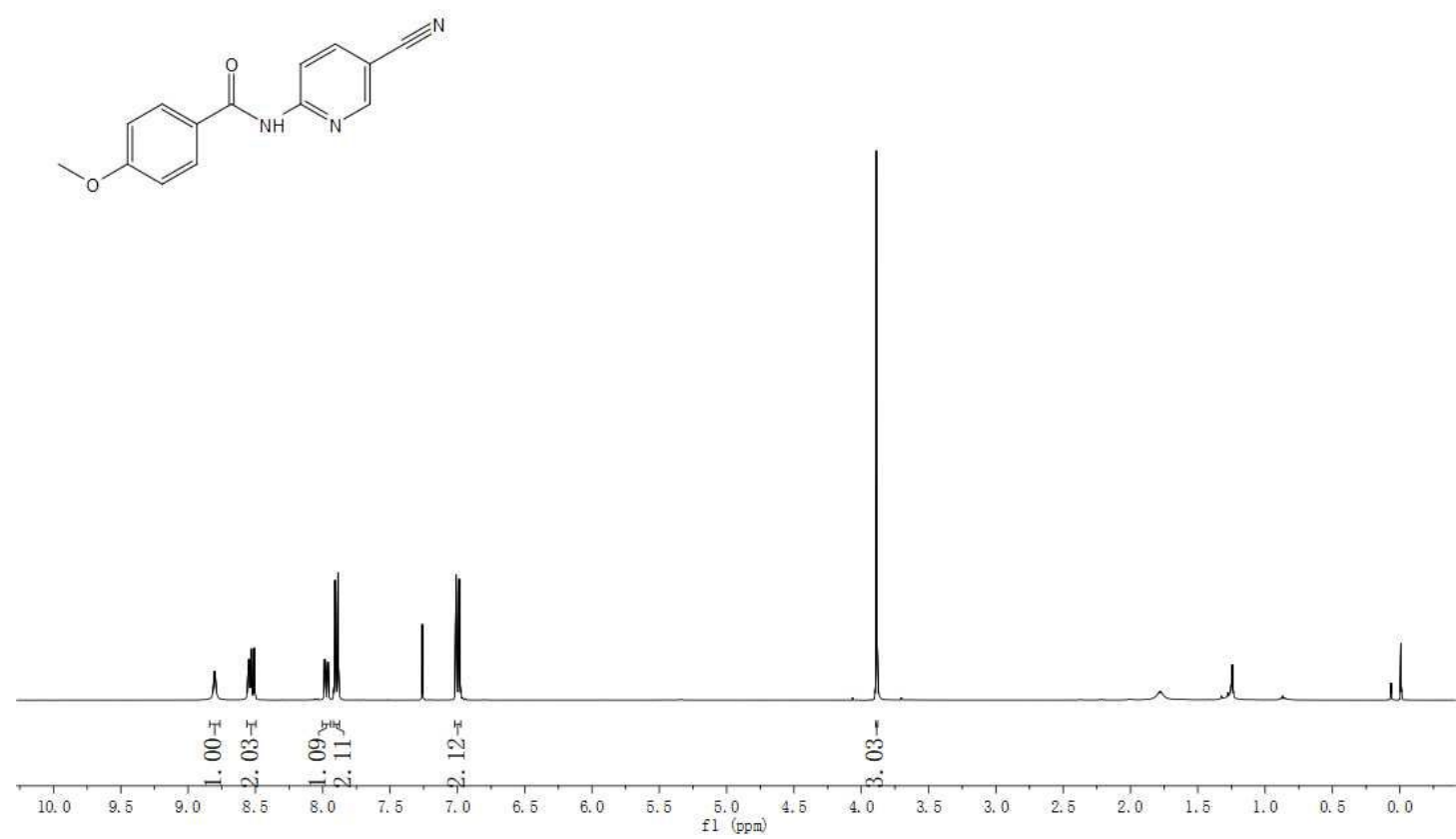

Figure S31. $400 \mathrm{MHz}{ }^{1} \mathrm{H}$ NMR spectrum of 3p in $\mathrm{CDCl}_{3}$.

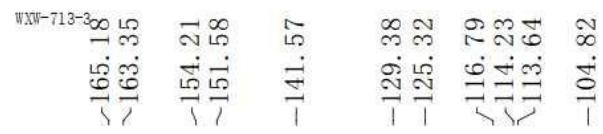

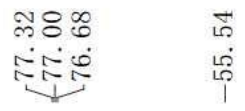

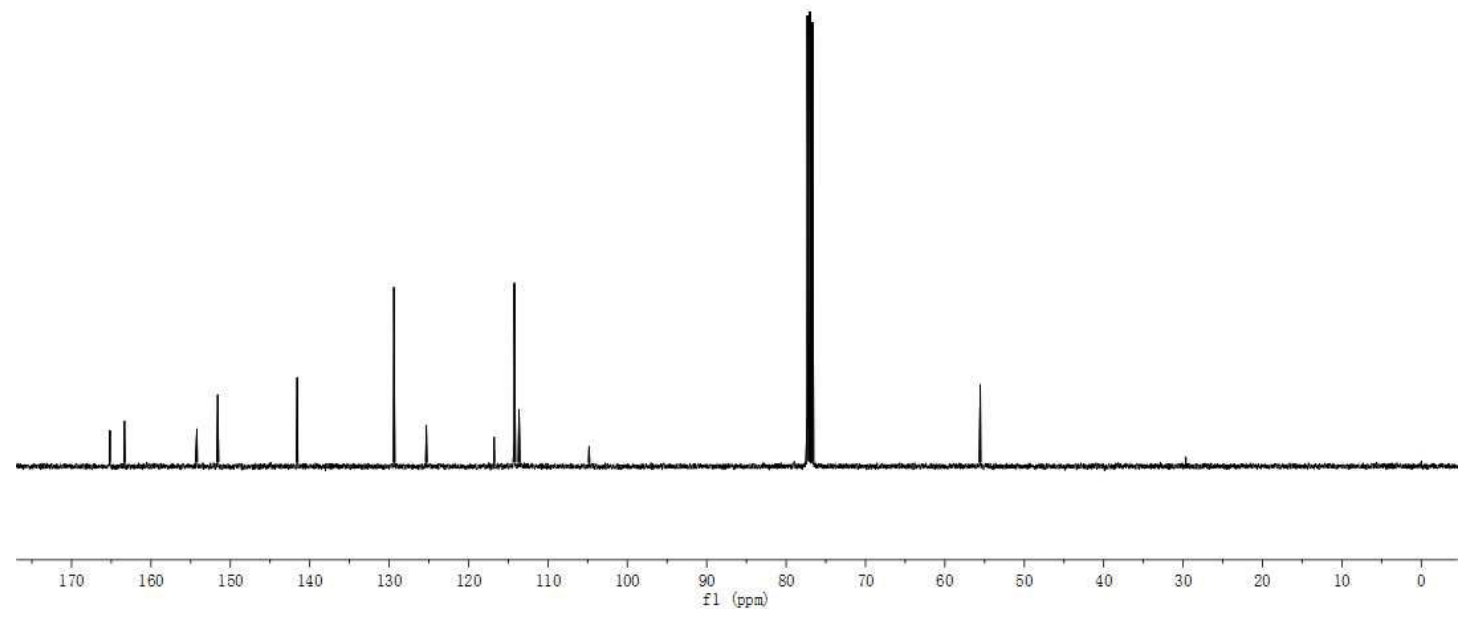

Figure S32. $100 \mathrm{MHz}{ }^{13} \mathrm{C}\left\{{ }^{1} \mathrm{H}\right\}$ NMR spectrum of $\mathbf{3 p}$ in $\mathrm{CDCl}_{3}$. 


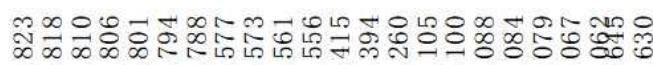

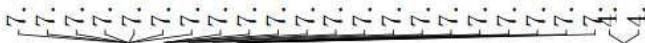<smiles>C#Cc1ccc(CNC(=O)c2ccc(F)cc2)cc1</smiles>

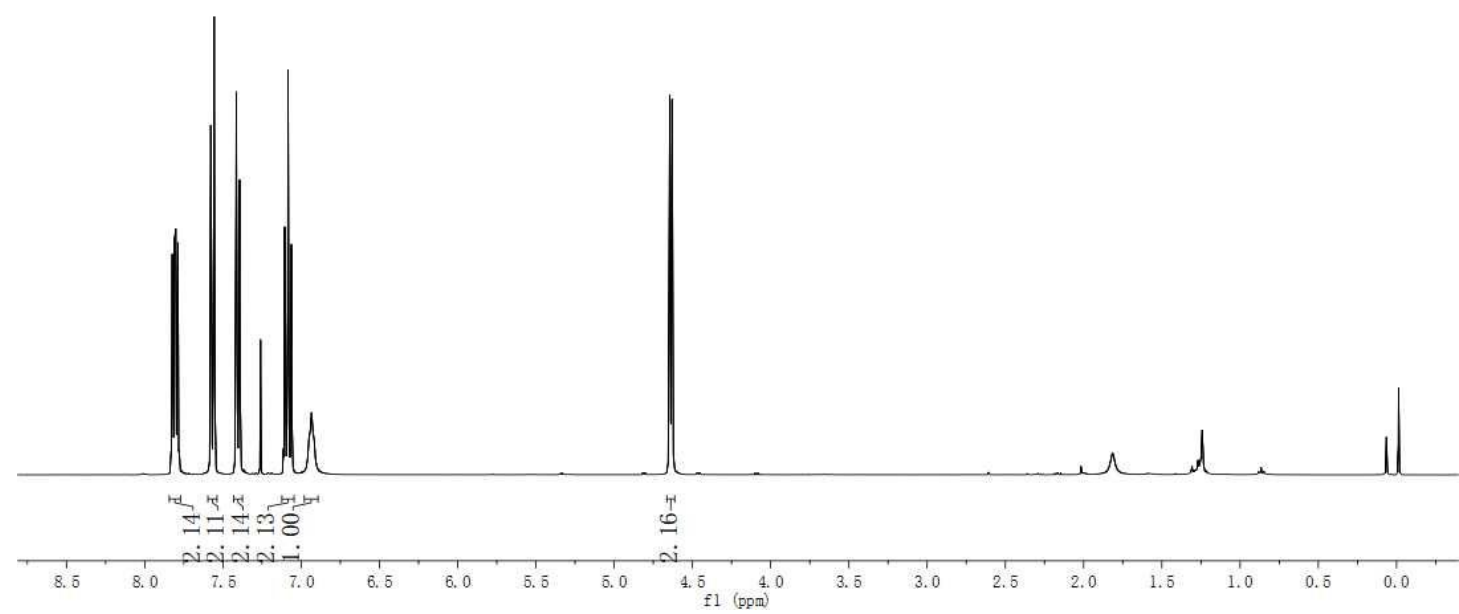

Figure S33. $400 \mathrm{MHz}{ }^{1} \mathrm{H}$ NMR spectrum of $\mathbf{3 q}$ in $\mathrm{CDCl}_{3}$.

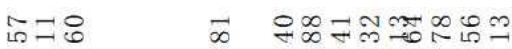

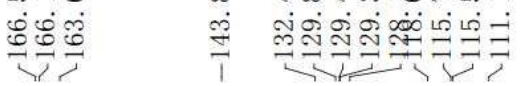

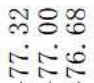

พั้

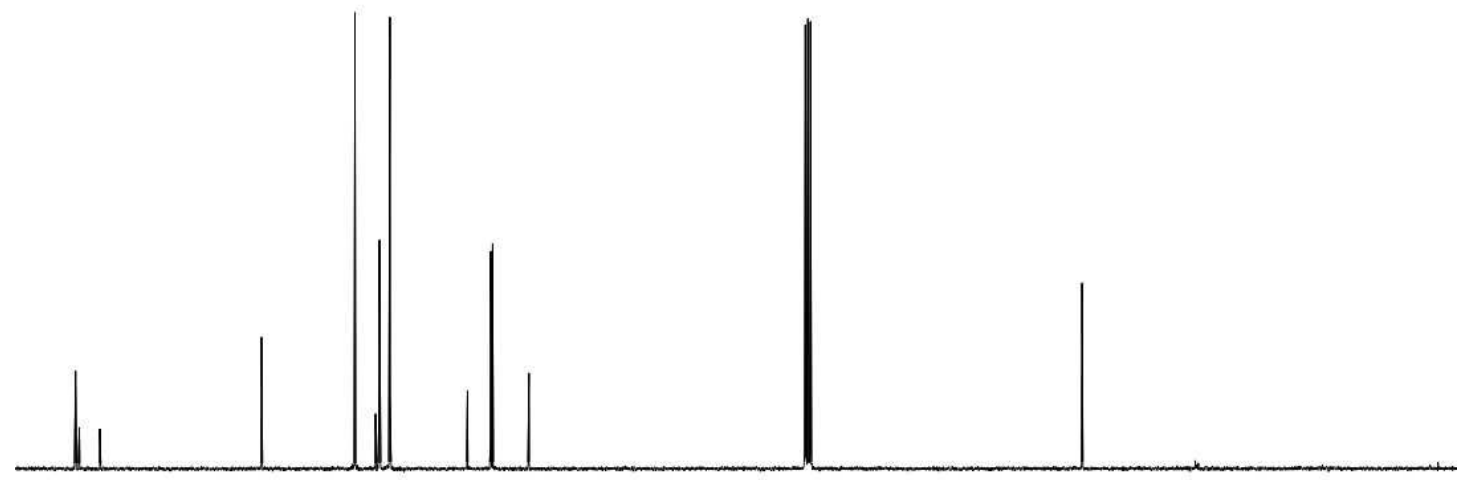

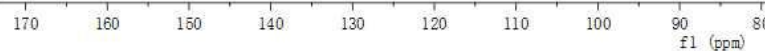

Figure S34. $100 \mathrm{MHz}{ }^{13} \mathrm{C}\left\{{ }^{1} \mathrm{H}\right\}$ NMR spectrum of $\mathbf{3 q}$ in $\mathrm{CDCl}_{3}$. 


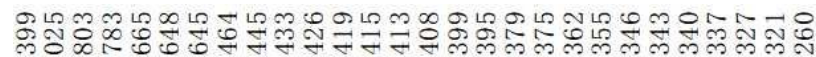

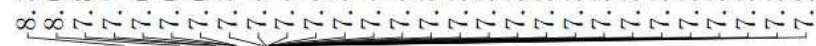<smiles>N#Cc1cccc(NC(=O)c2ccccc2Cl)c1</smiles>

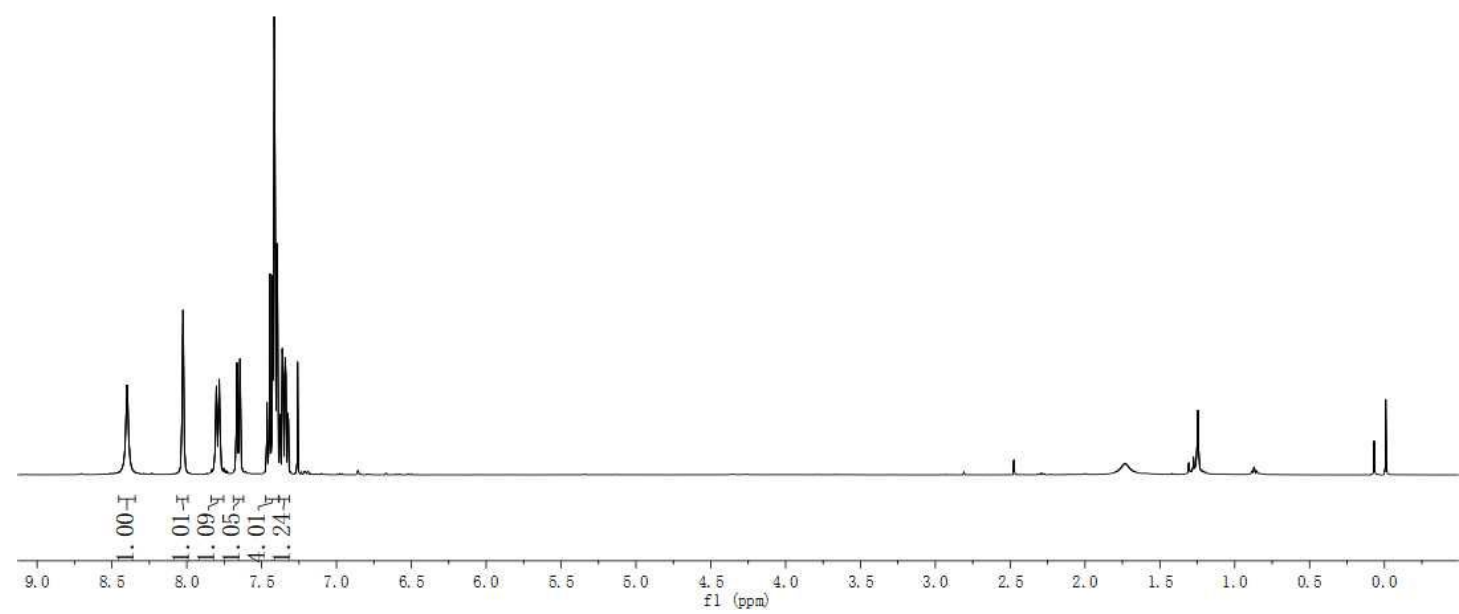

Figure S35. $400 \mathrm{MHz}{ }^{1} \mathrm{H}$ NMR spectrum of $\mathbf{3 r}$ in $\mathrm{CDCl}_{3}$.

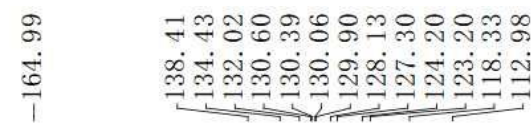

నిం:

순요
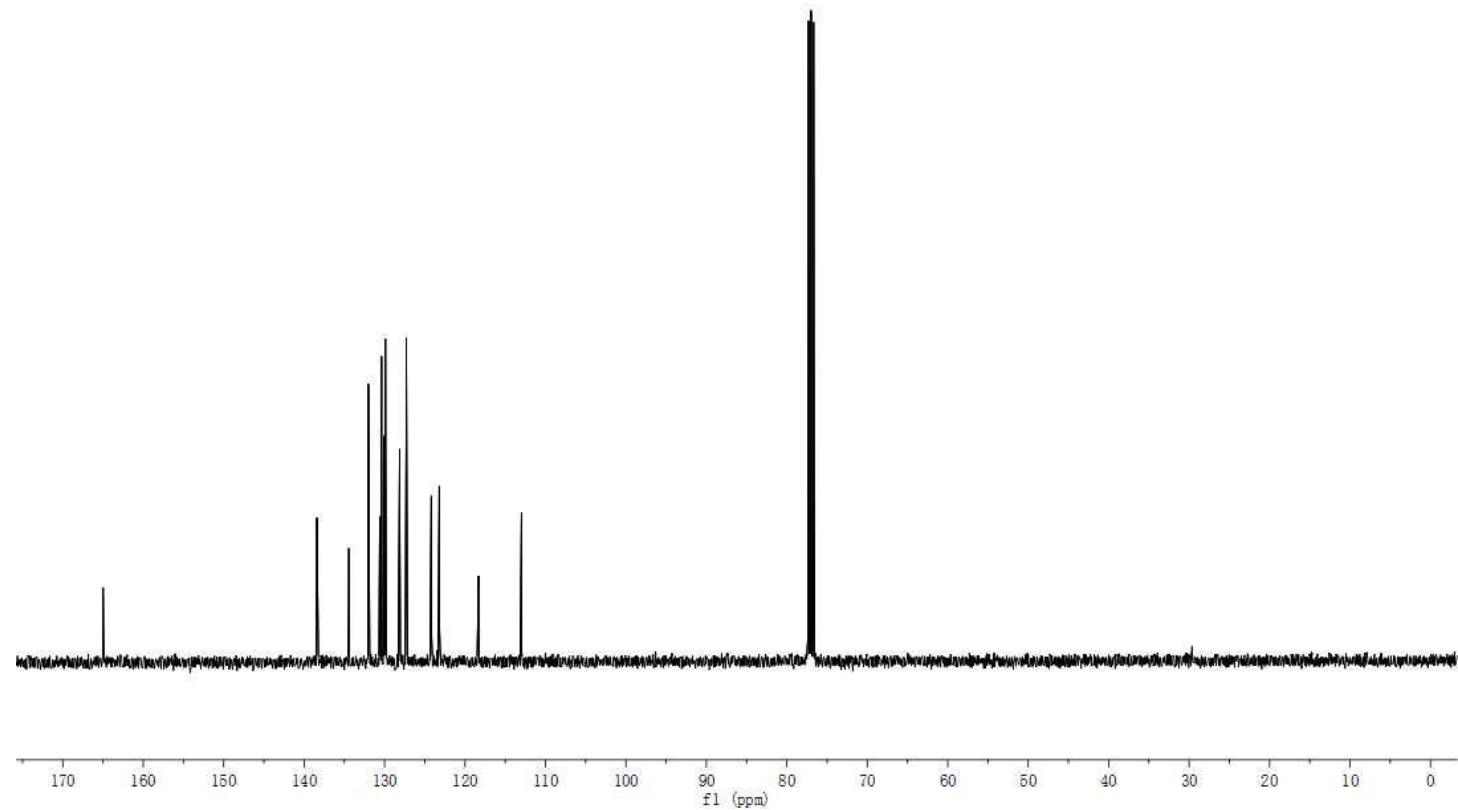

Figure S36. $100 \mathrm{MHz}{ }^{13} \mathrm{C}\left\{{ }^{1} \mathrm{H}\right\}$ NMR spectrum of $3 \mathbf{r}$ in $\mathrm{CDCl}_{3}$. 


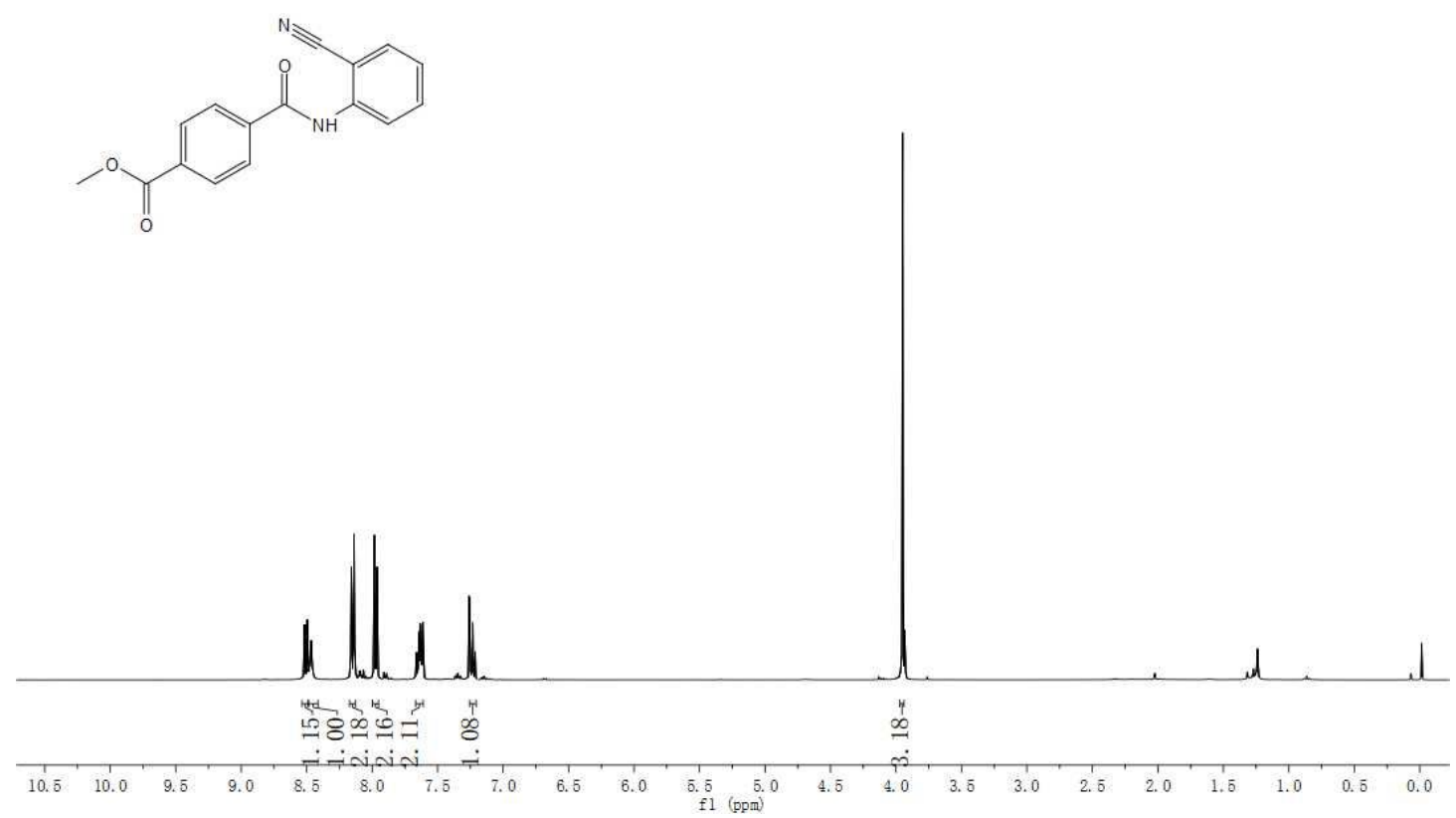

Figure S37. $400 \mathrm{MHz}{ }^{1} \mathrm{H}$ NMR spectrum of 3s in $\mathrm{CDCl}_{3}$.

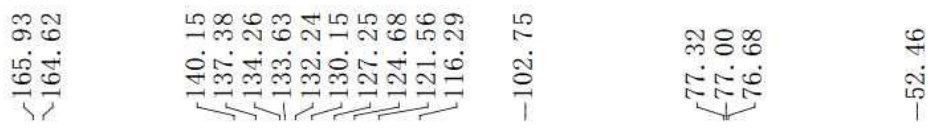
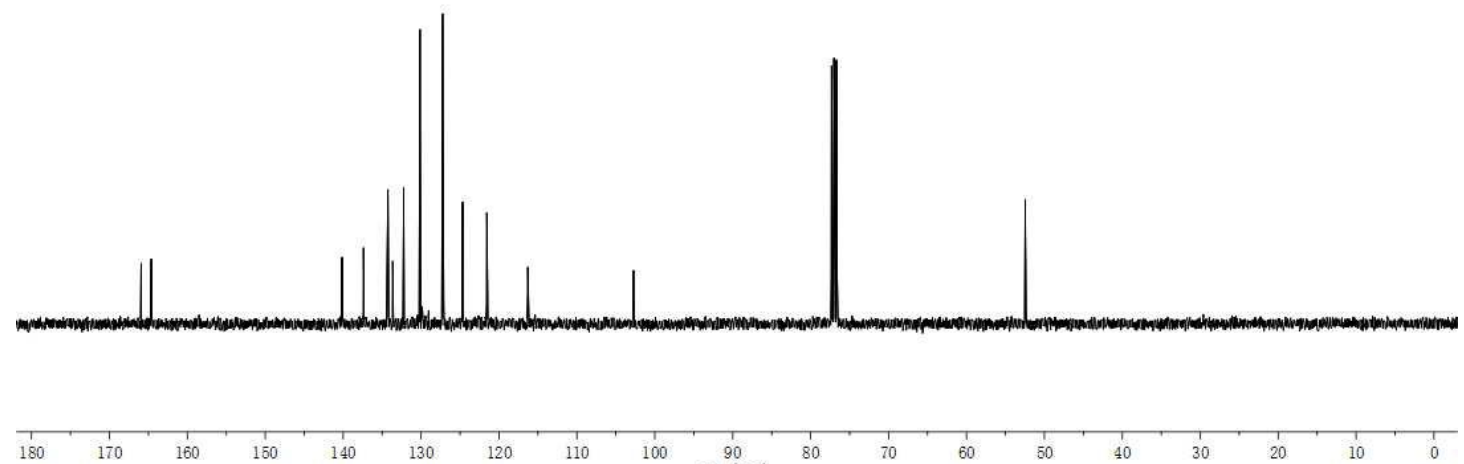

Figure S38. $100 \mathrm{MHz}{ }^{13} \mathrm{C}\left\{{ }^{1} \mathrm{H}\right\}$ NMR spectrum of 3s in $\mathrm{CDCl}_{3}$. 


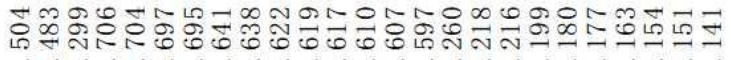

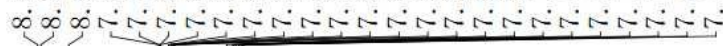
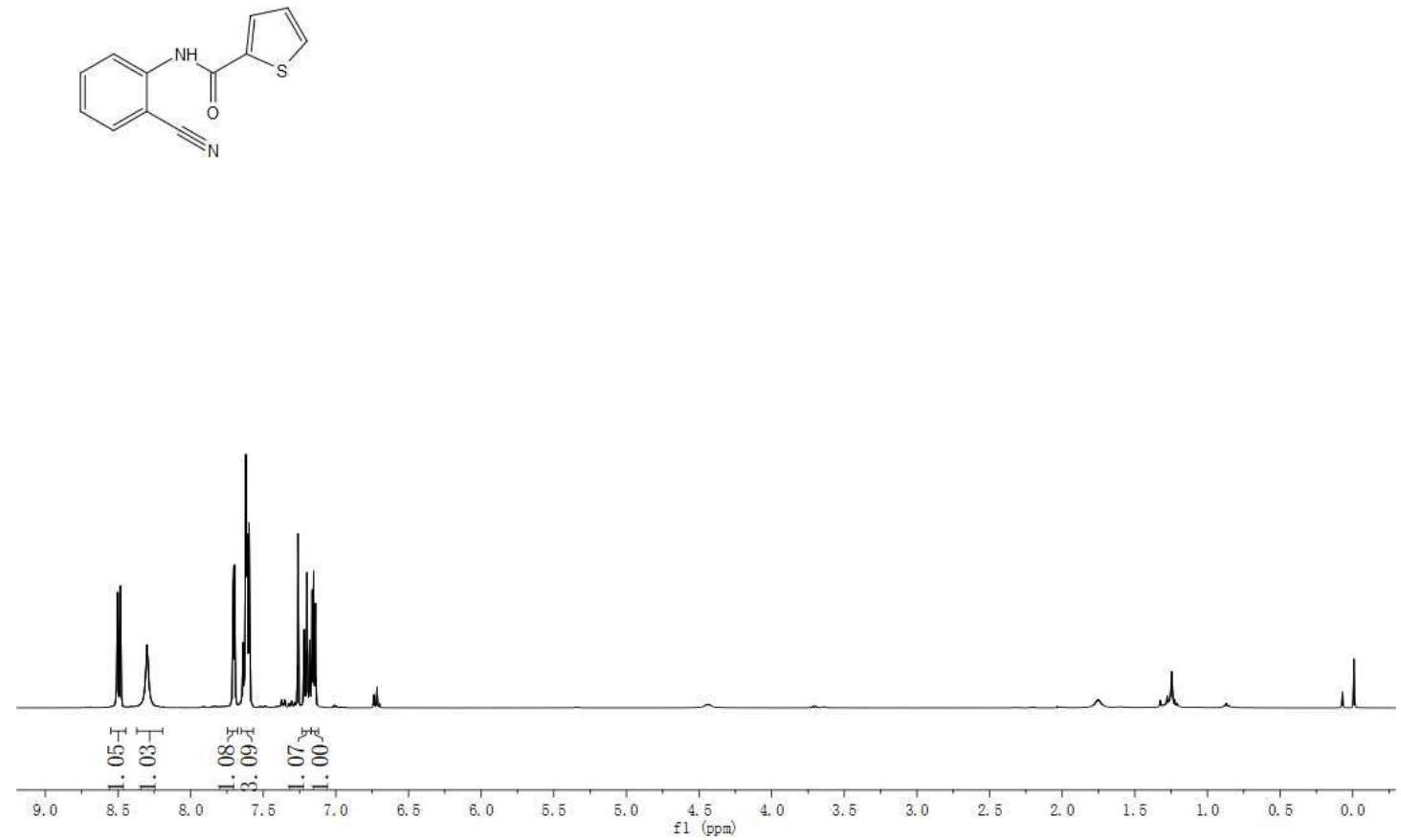

Figure S39. $400 \mathrm{MHz}{ }^{1} \mathrm{H}$ NMR spectrum of $3 \mathbf{t}$ in $\mathrm{CDCl}_{3}$.

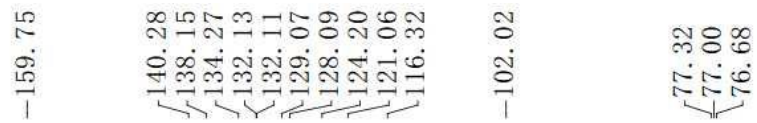
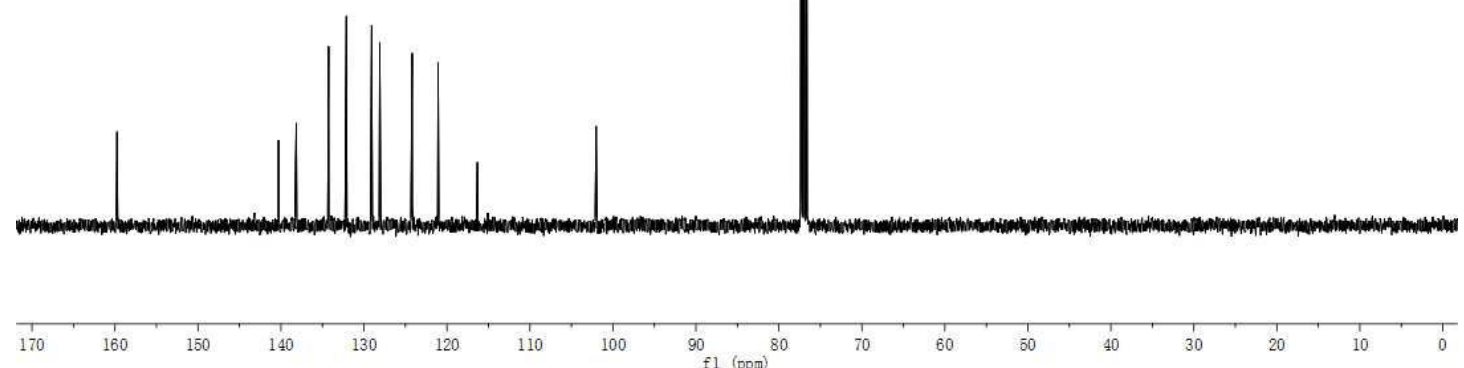

Figure S40. $100 \mathrm{MHz}{ }^{13} \mathrm{C}\left\{{ }^{1} \mathrm{H}\right\}$ NMR spectrum of $\mathbf{3 t}$ in $\mathrm{CDCl}_{3}$. 

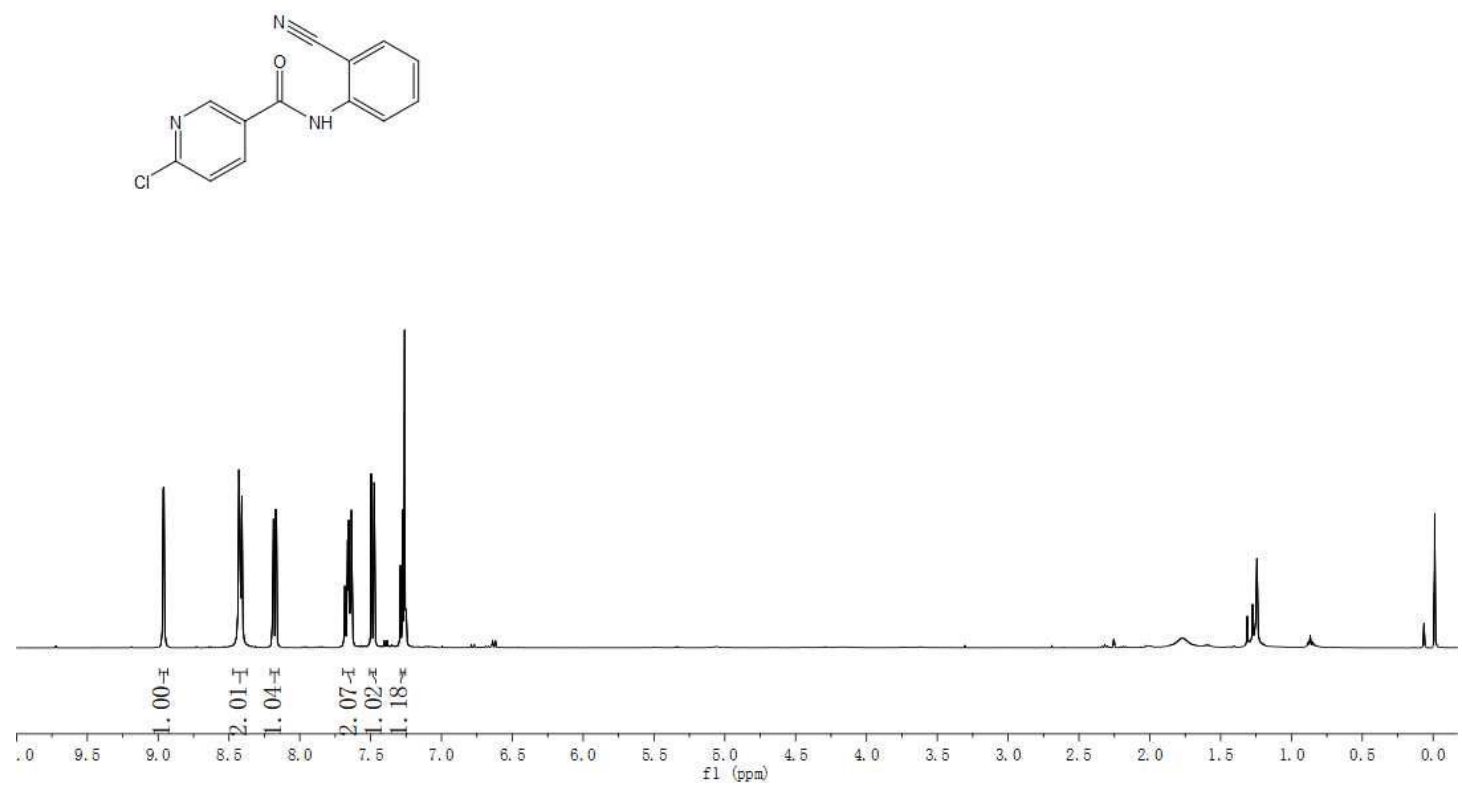

Figure S41. $400 \mathrm{MHz}{ }^{1} \mathrm{H}$ NMR spectrum of $\mathbf{3 u}$ in $\mathrm{CDCl}_{3}$.
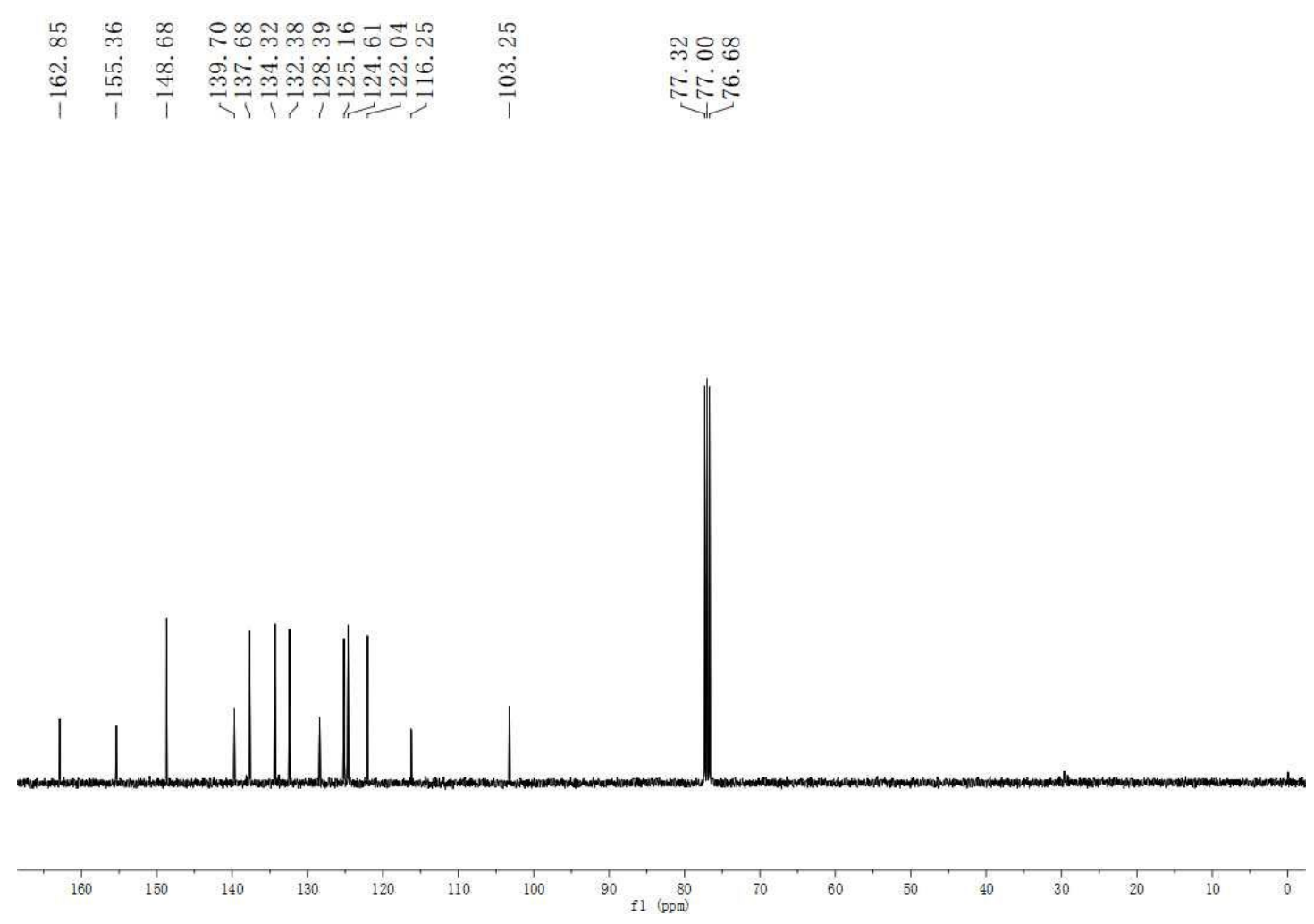

Figure S42. $100 \mathrm{MHz}{ }^{13} \mathrm{C}\left\{{ }^{1} \mathrm{H}\right\}$ NMR spectrum of $\mathbf{3 u}$ in $\mathrm{CDCl}_{3}$. 


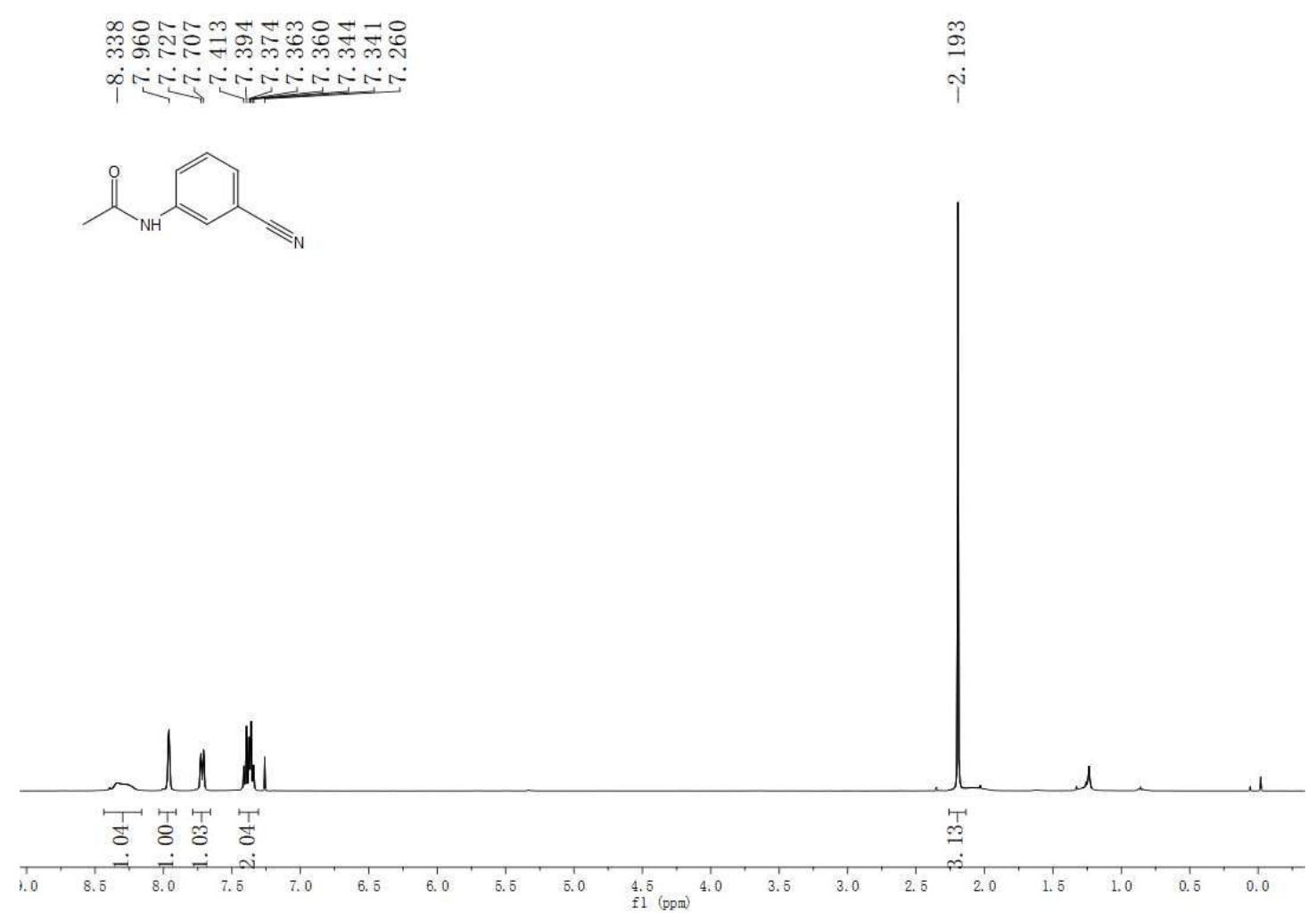

Figure $\mathbf{S 4 3 .} 400 \mathrm{MHz}{ }^{1} \mathrm{H} \mathrm{NMR}$ spectrum of $\mathbf{3 v}$ in $\mathrm{CDCl}_{3}$.

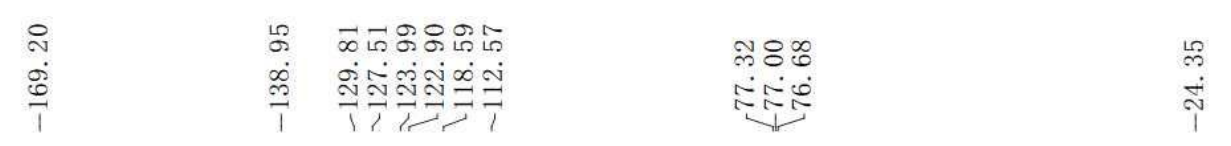

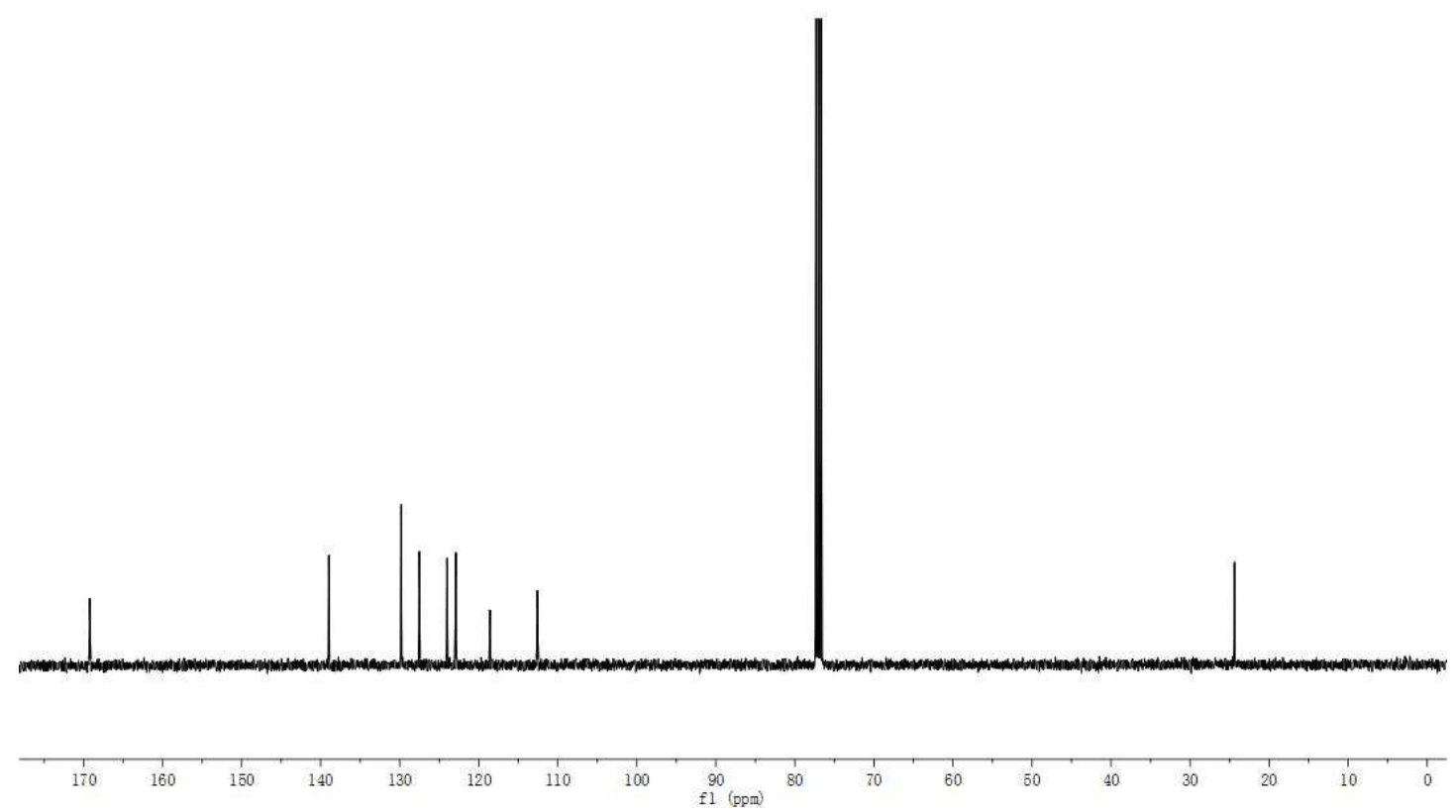

Figure S44. $100 \mathrm{MHz}{ }^{13} \mathrm{C}\left\{{ }^{1} \mathrm{H}\right\} \mathrm{NMR}$ spectrum of $\mathbf{3 v}$ in $\mathrm{CDCl}_{3}$. 


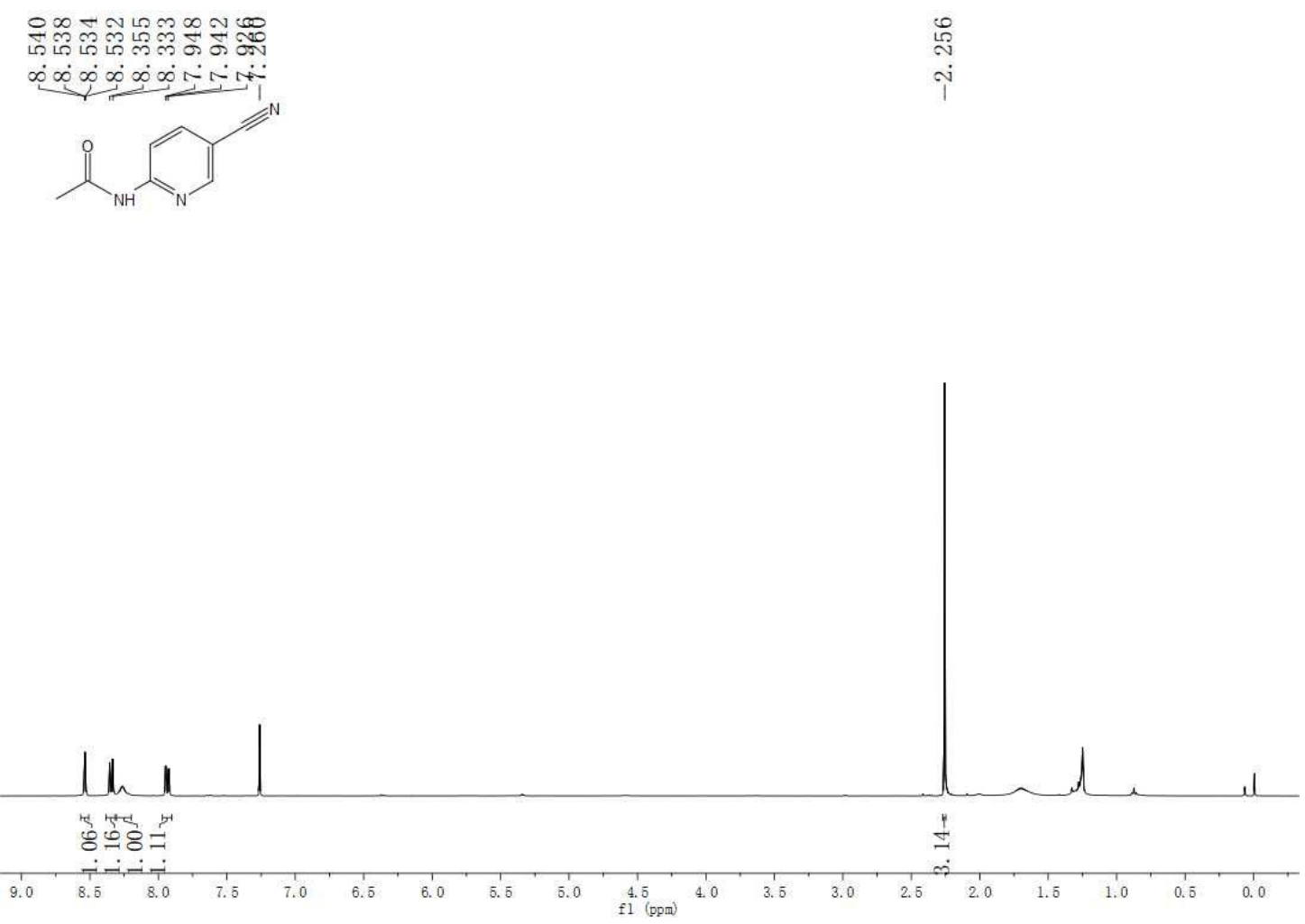

Figure S45. $400 \mathrm{MHz}{ }^{1} \mathrm{H}$ NMR spectrum of $\mathbf{3 w}$ in $\mathrm{CDCl}_{3}$.

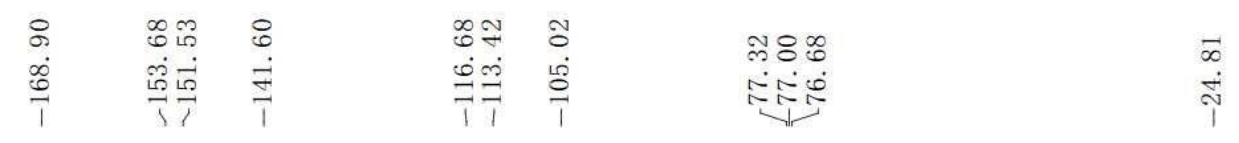

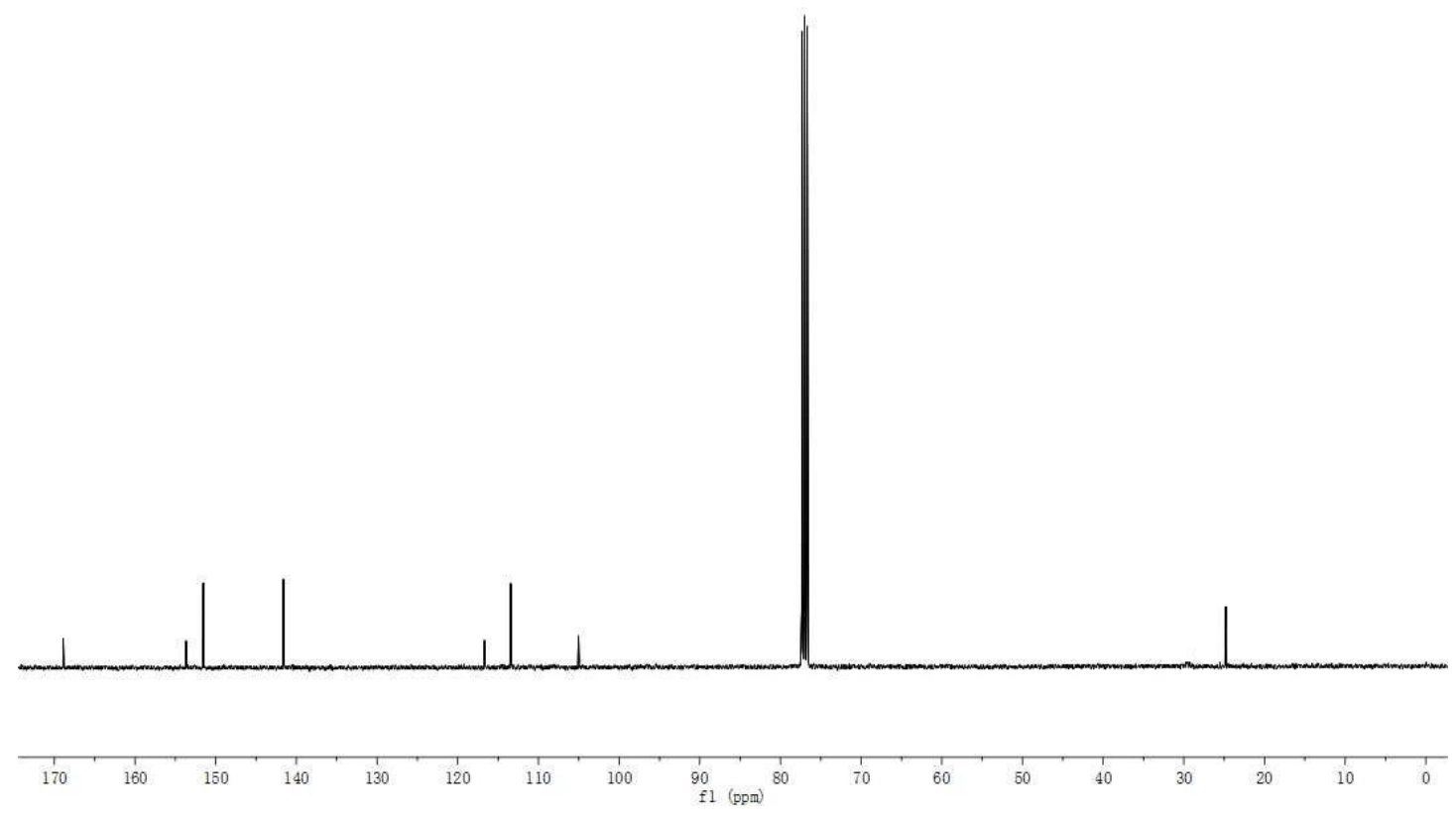

Figure S46. $100 \mathrm{MHz}{ }^{13} \mathrm{C}\left\{{ }^{1} \mathrm{H}\right\}$ NMR spectrum of $\mathbf{3 w}$ in $\mathrm{CDCl}_{3}$. 

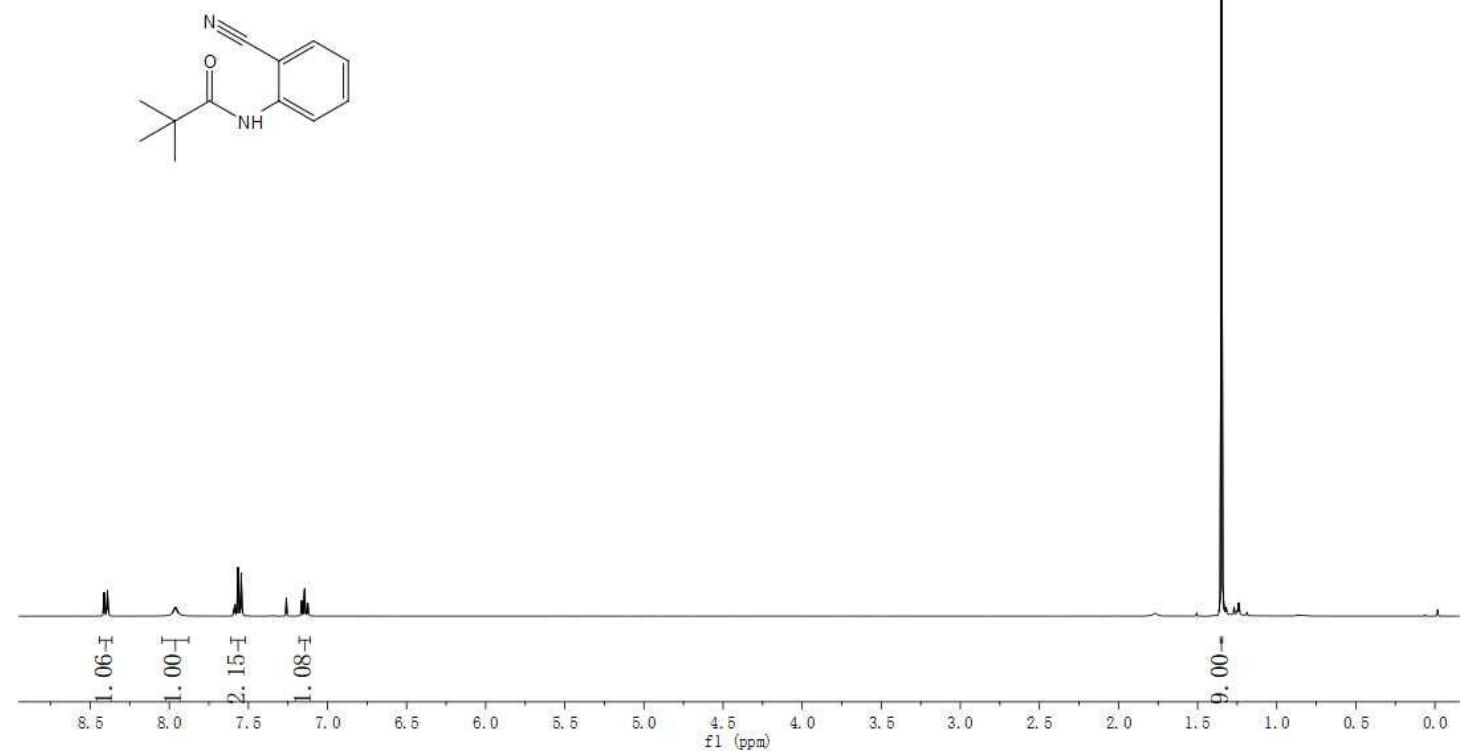

Figure $\mathbf{S 4 7 .} 400 \mathrm{MHz}{ }^{1} \mathrm{H}$ NMR spectrum of $\mathbf{3 x}$ in $\mathrm{CDCl}_{3}$.

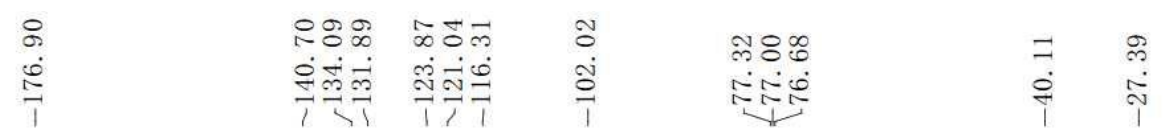

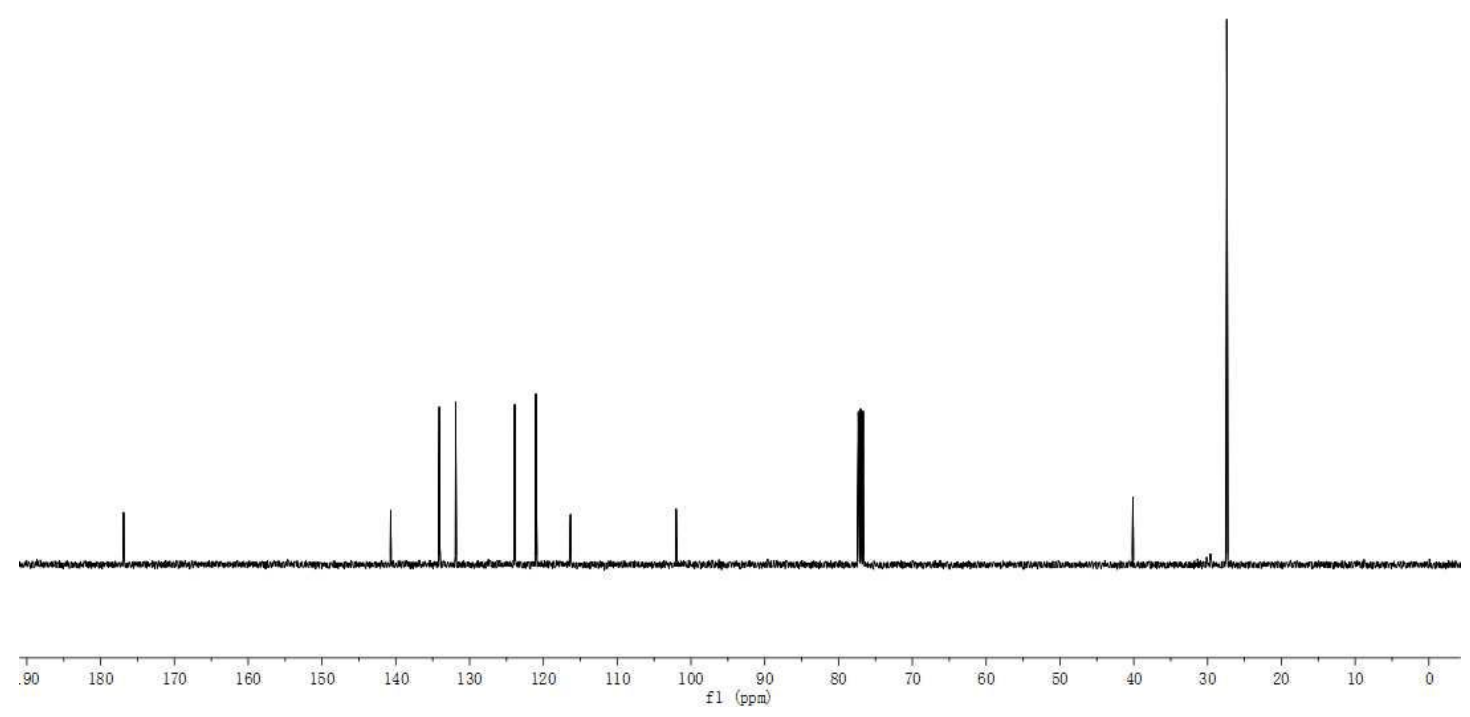

Figure S48. $100 \mathrm{MHz}{ }^{13} \mathrm{C}\left\{{ }^{1} \mathrm{H}\right\}$ NMR spectrum of $\mathbf{3 x}$ in $\mathrm{CDCl}_{3}$. 


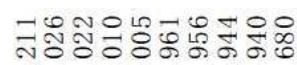

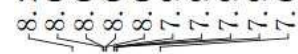

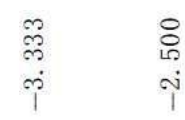
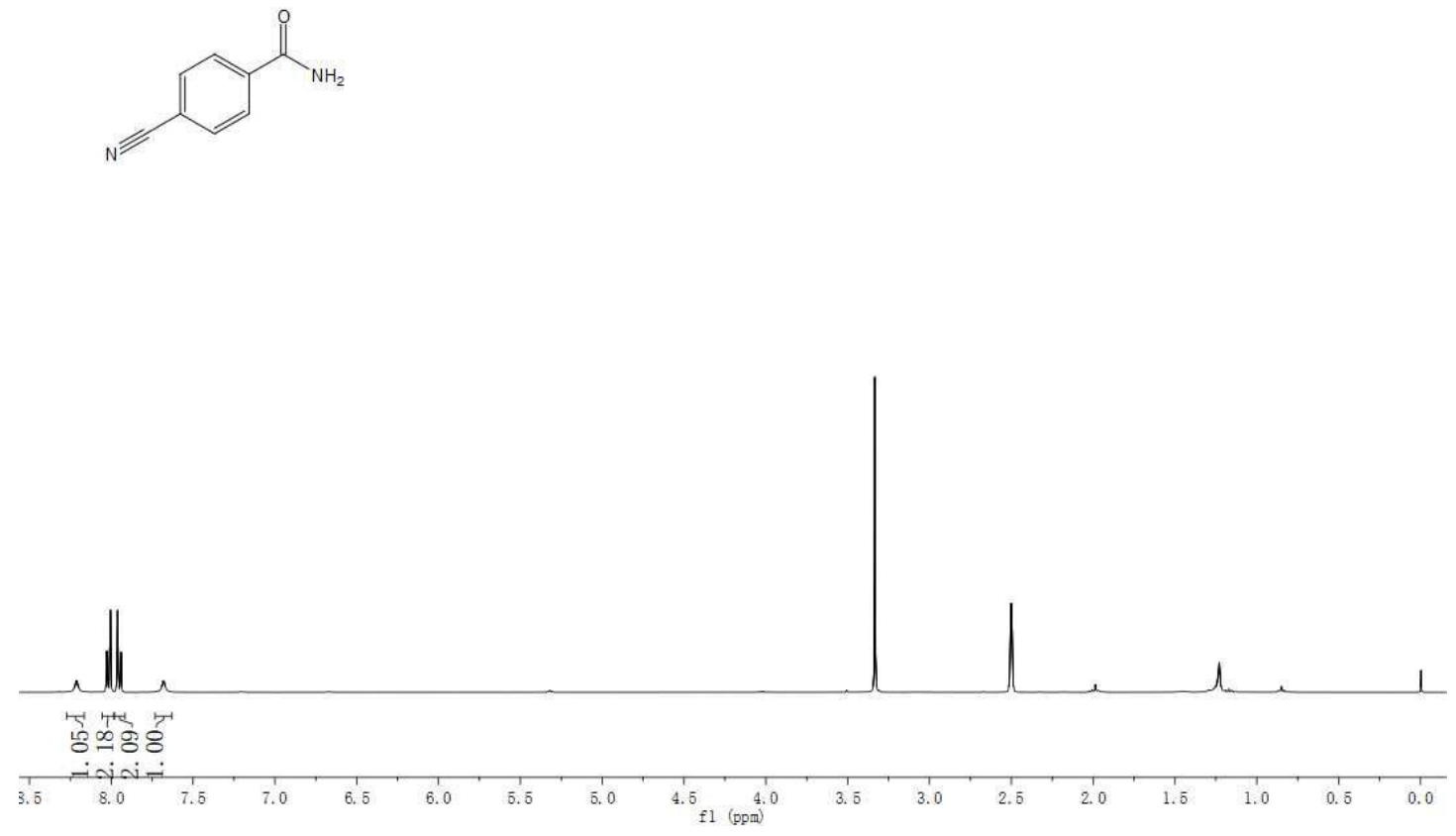

Figure S49. $400 \mathrm{MHz}{ }^{1} \mathrm{H}$ NMR spectrum of $\mathbf{3 y}$ in DMSO-D 6 .

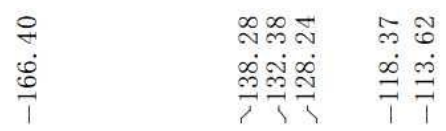

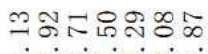

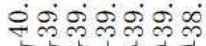

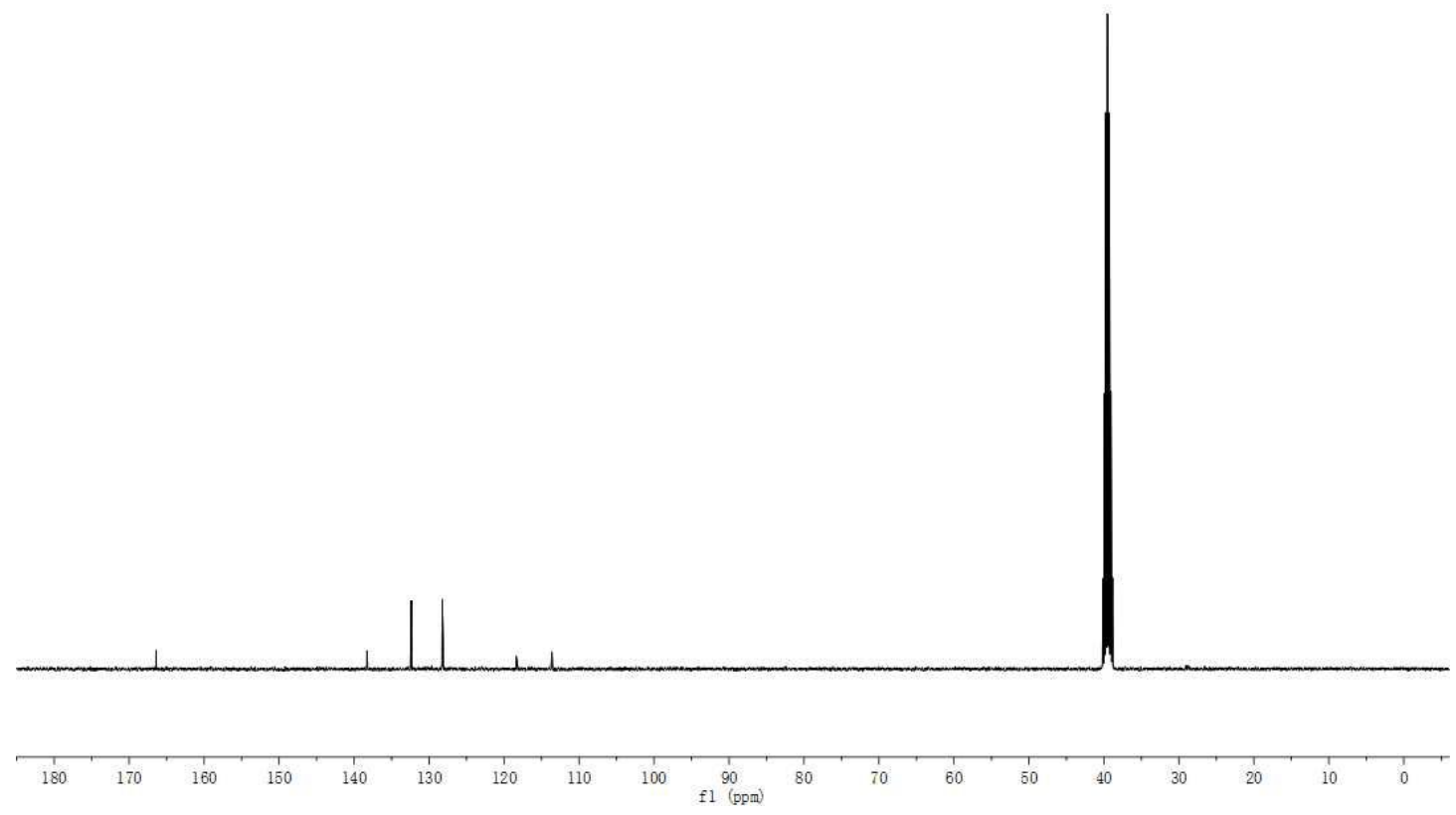

Figure S50. $100 \mathrm{MHz}{ }^{13} \mathrm{C}\left\{{ }^{1} \mathrm{H}\right\}$ NMR spectrum of $\mathbf{3 y}$ in DMSO-D 6 . 


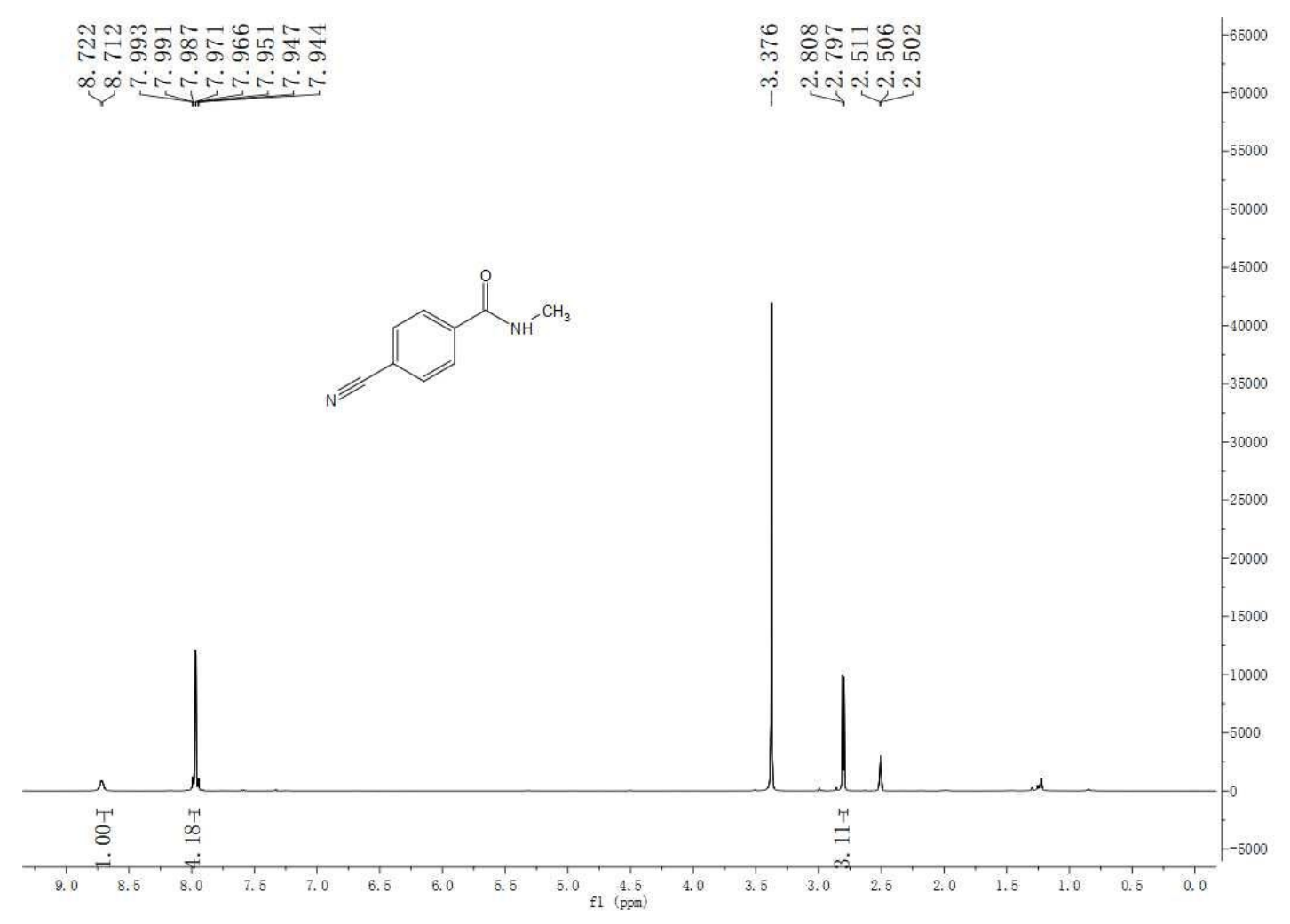

Figure S51. $400 \mathrm{MHz}{ }^{1} \mathrm{H}$ NMR spectrum of $\mathbf{3 z}$ in DMSO-D .

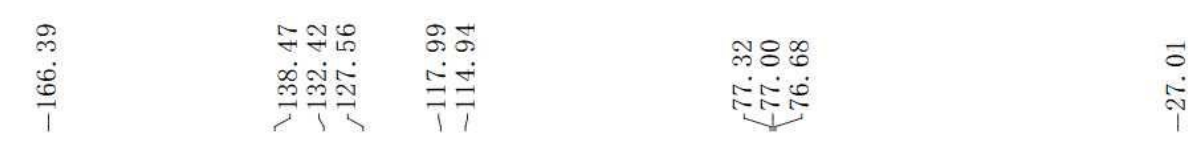

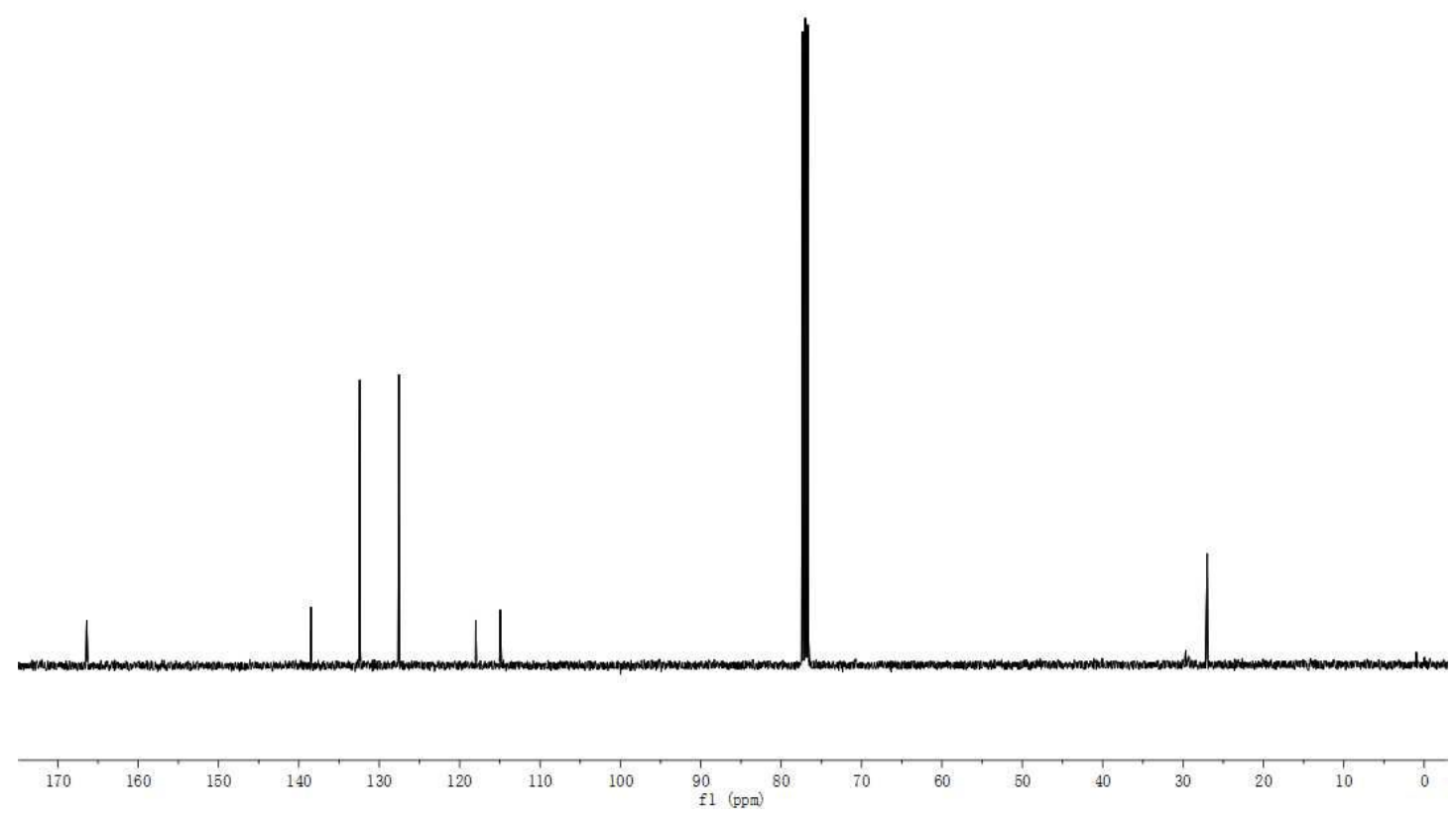

Figure S52. $100 \mathrm{MHz}{ }^{13} \mathrm{C}\left\{{ }^{1} \mathrm{H}\right\}$ NMR spectrum of $\mathbf{3 z}$ in $\mathrm{CDCl}_{3}$. 

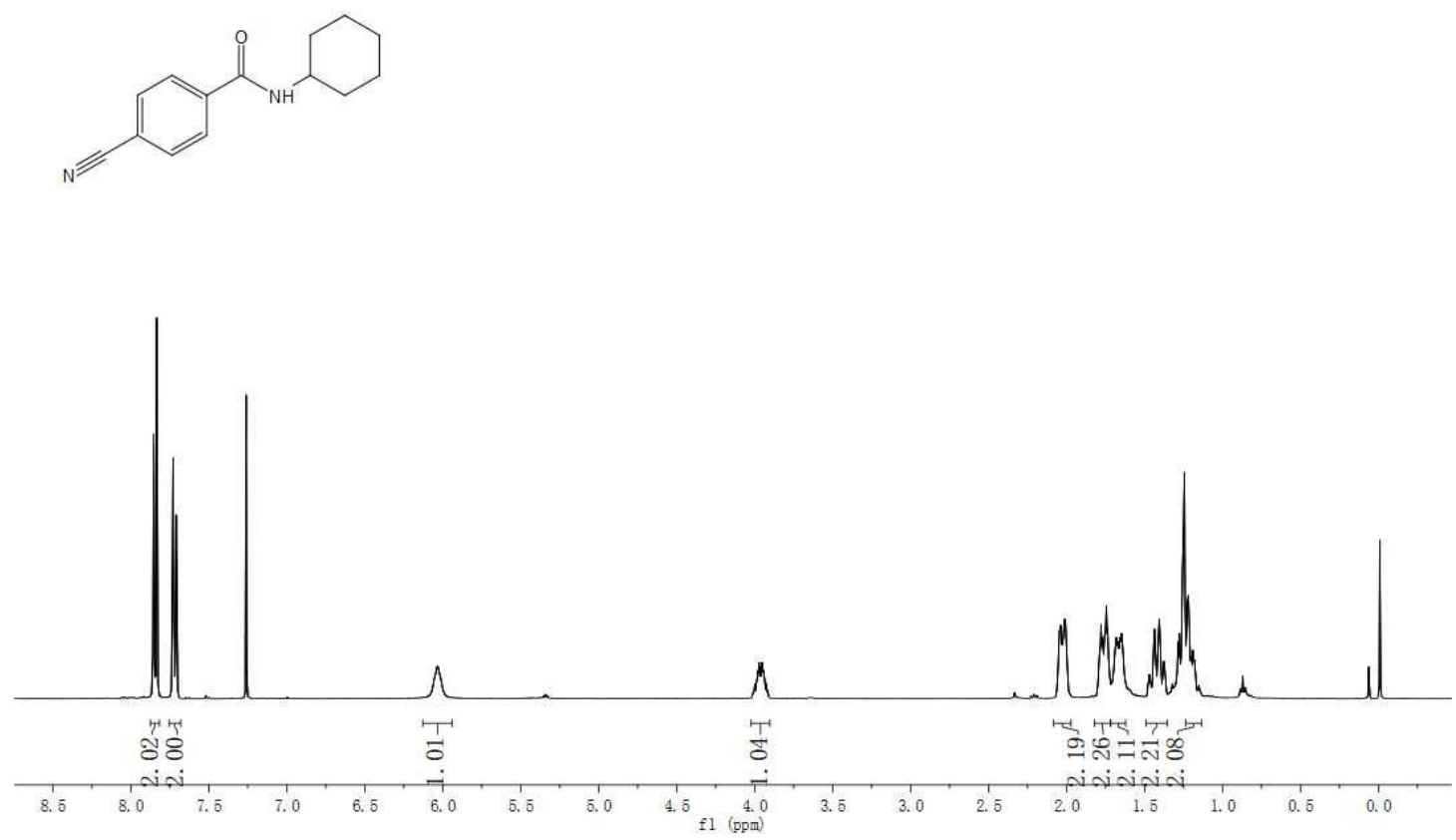

Figure S53. $400 \mathrm{MHz}{ }^{1} \mathrm{H}$ NMR spectrum of $\mathbf{3 a a}$ in $\mathrm{CDCl}_{3}$.

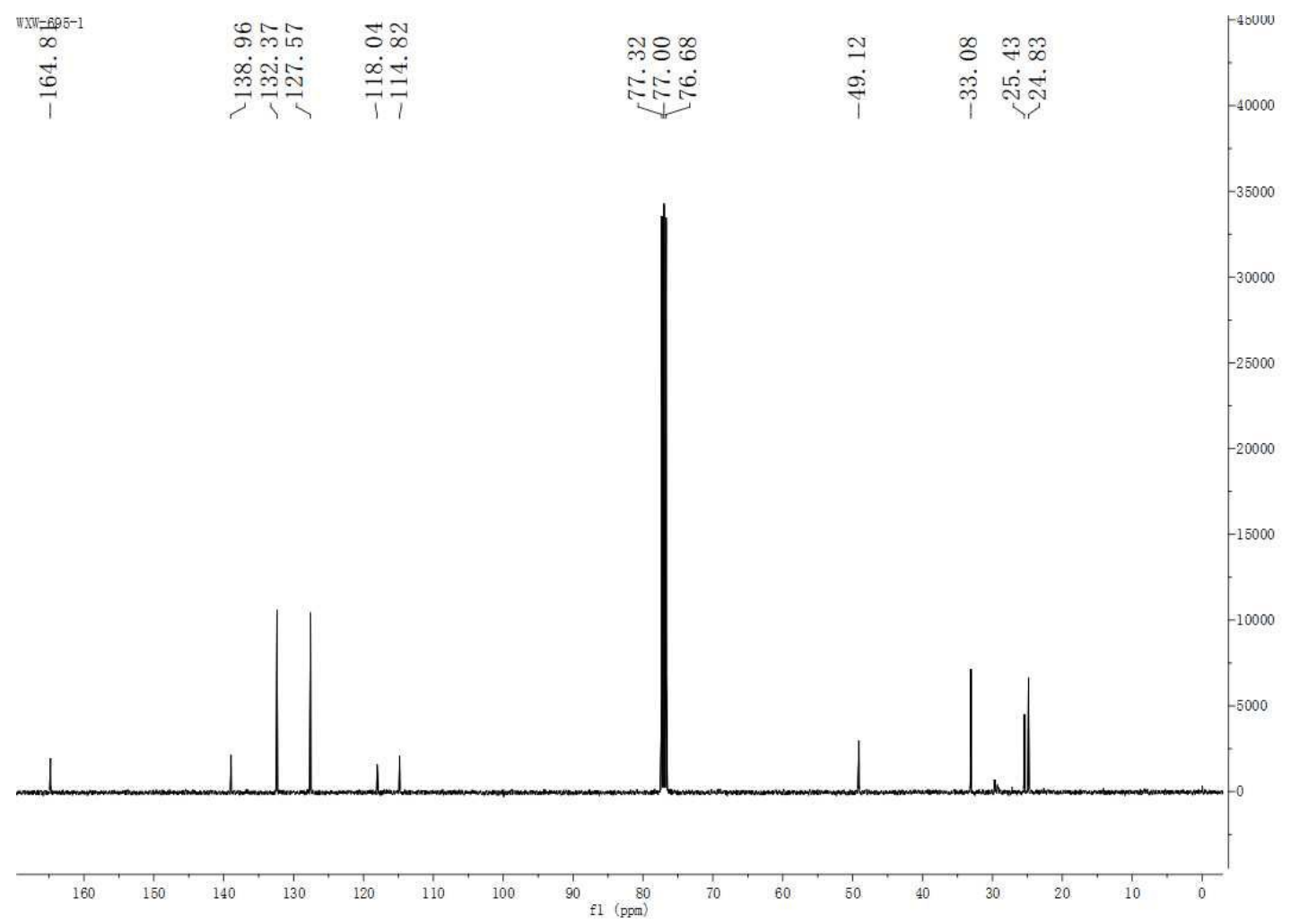

Figure S54. $100 \mathrm{MHz}{ }^{13} \mathrm{C}\left\{{ }^{1} \mathrm{H}\right\}$ NMR spectrum of 3aa in $\mathrm{CDCl}_{3}$. 

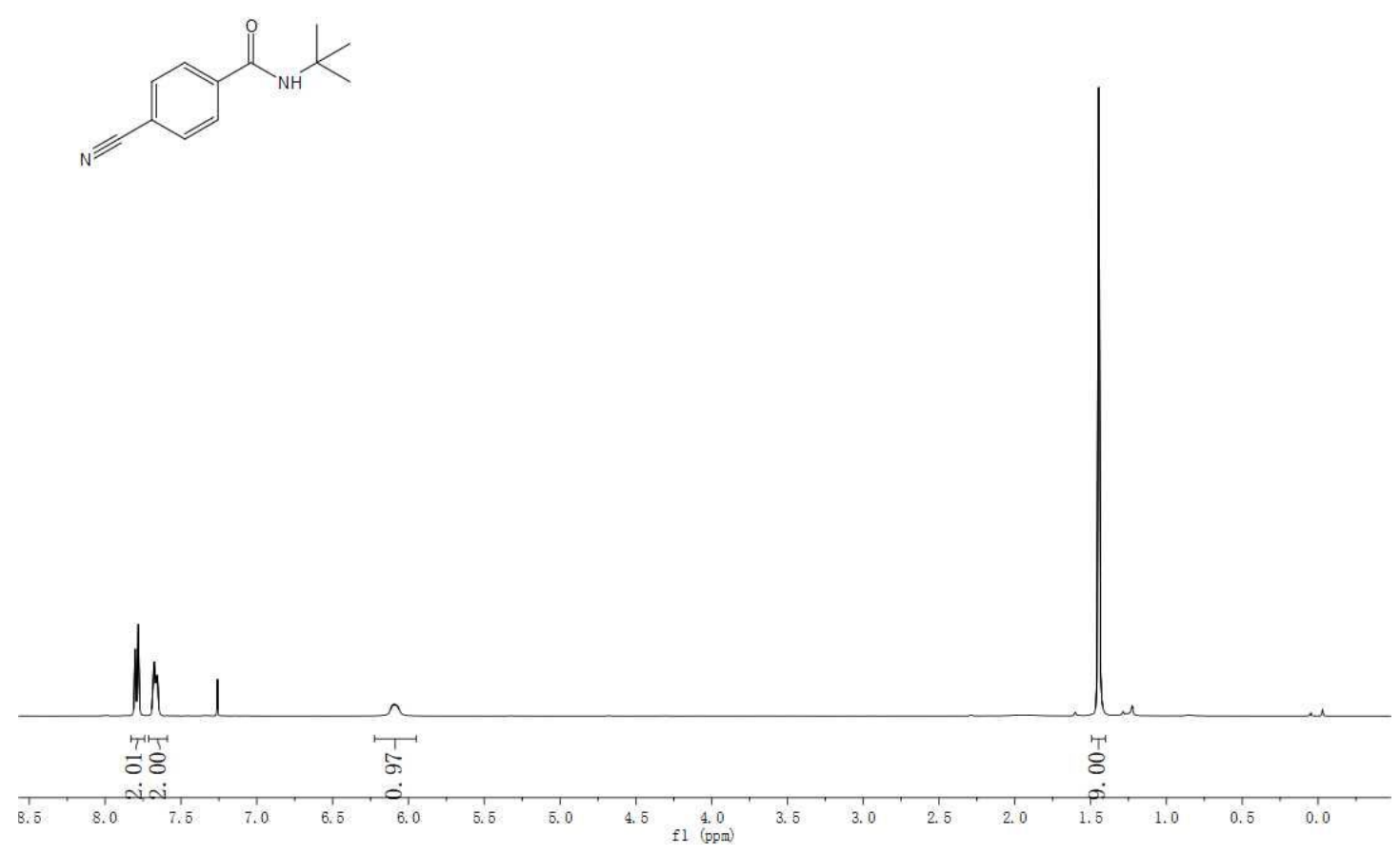

Figure S55. $400 \mathrm{MHz}{ }^{1} \mathrm{H}$ NMR spectrum of $\mathbf{3 a b}$ in $\mathrm{CDCl}_{3}$.

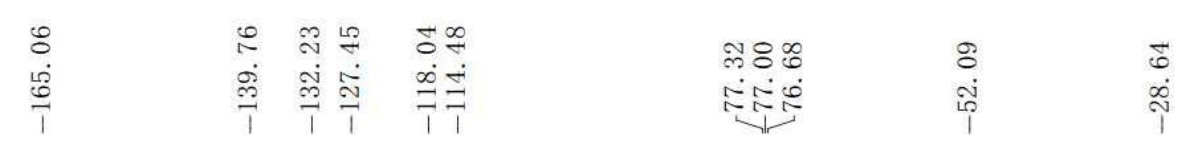

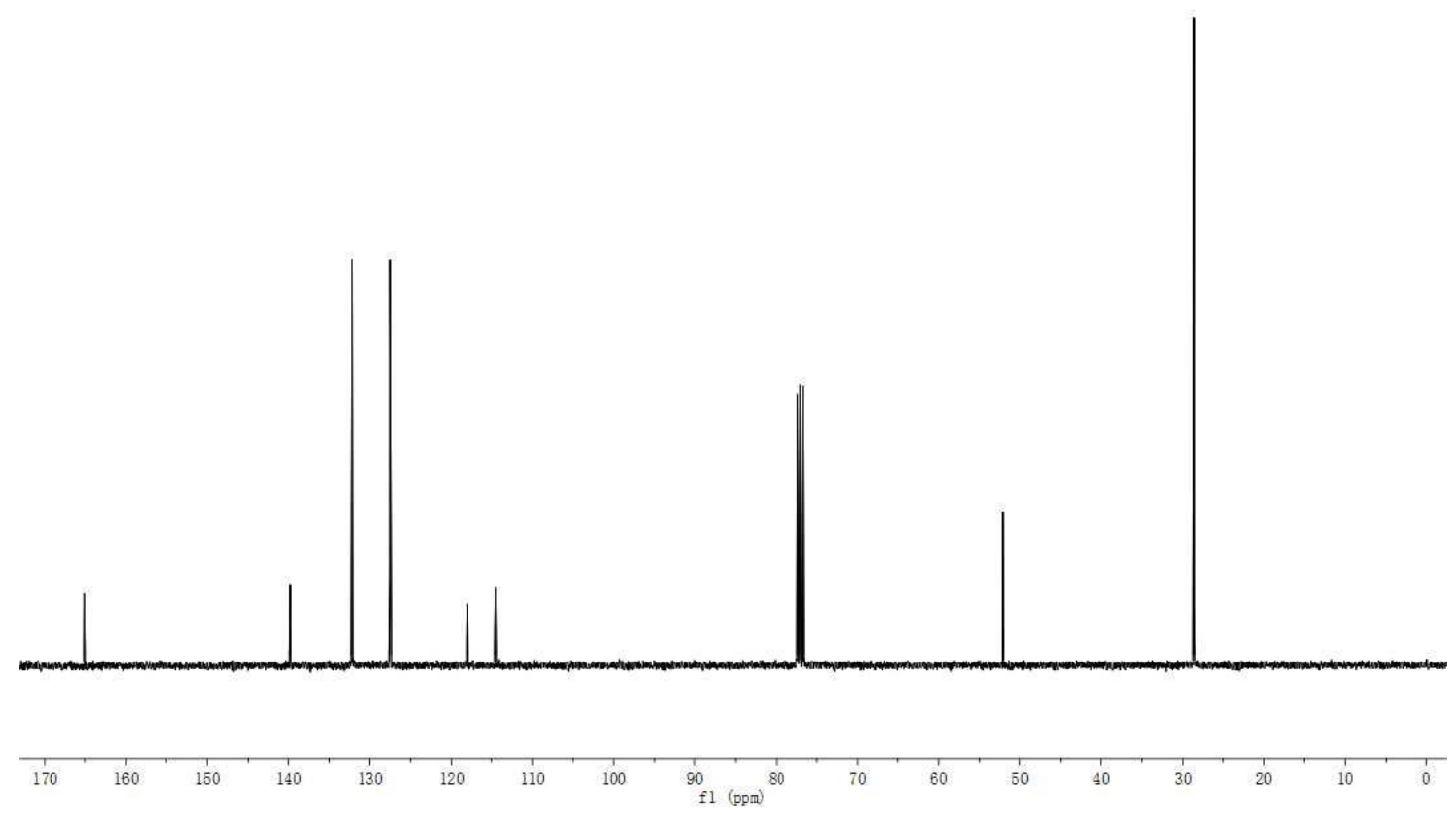

Figure S56. $100 \mathrm{MHz}{ }^{13} \mathrm{C}\left\{{ }^{1} \mathrm{H}\right\} \mathrm{NMR}$ spectrum of 3ab in $\mathrm{CDCl}_{3}$. 


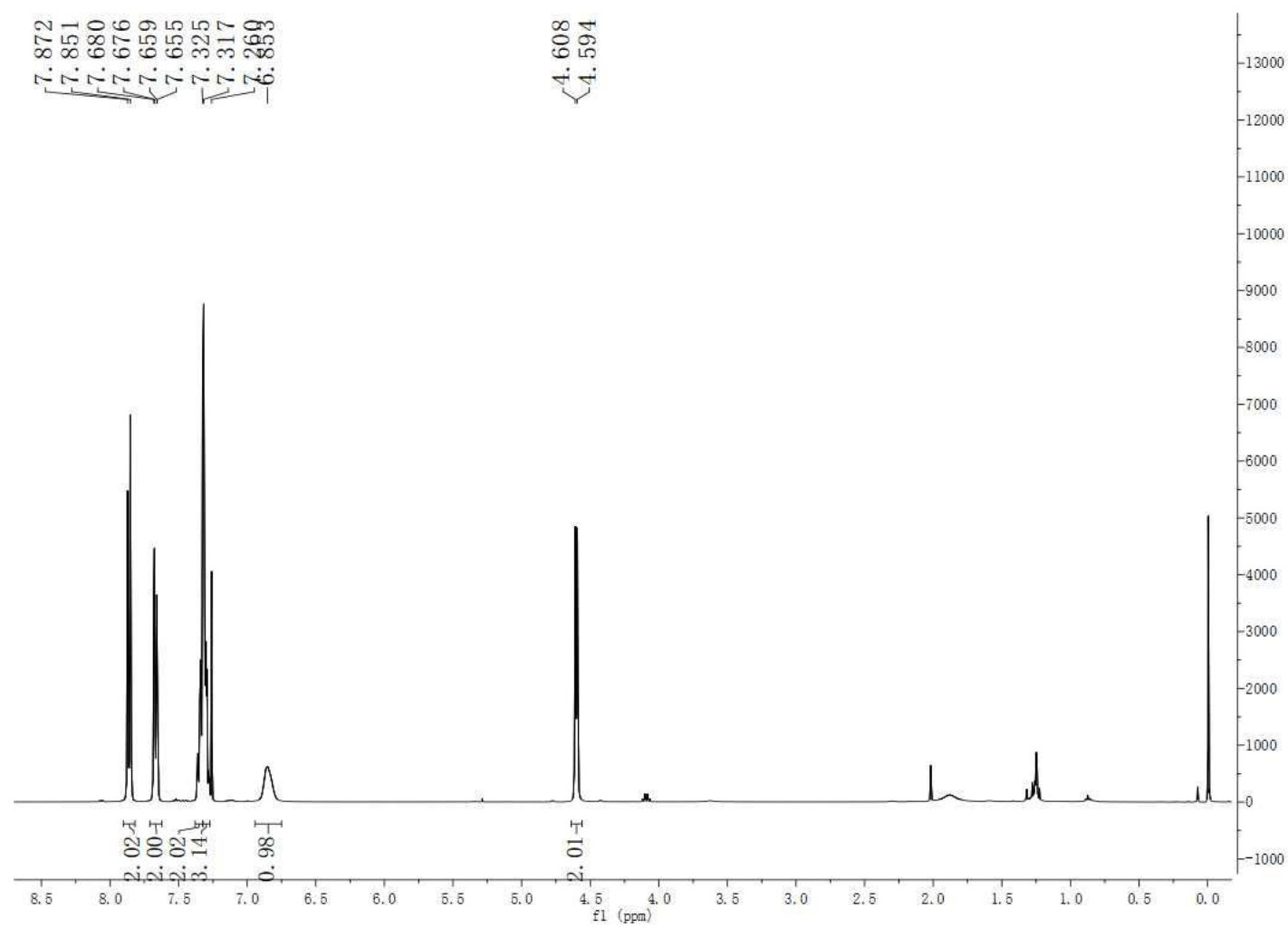

Figure S57. $400 \mathrm{MHz}{ }^{1} \mathrm{H}$ NMR spectrum of $\mathbf{3 a c}$ in $\mathrm{CDCl}_{3}$.

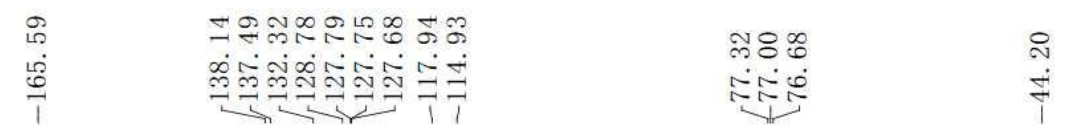
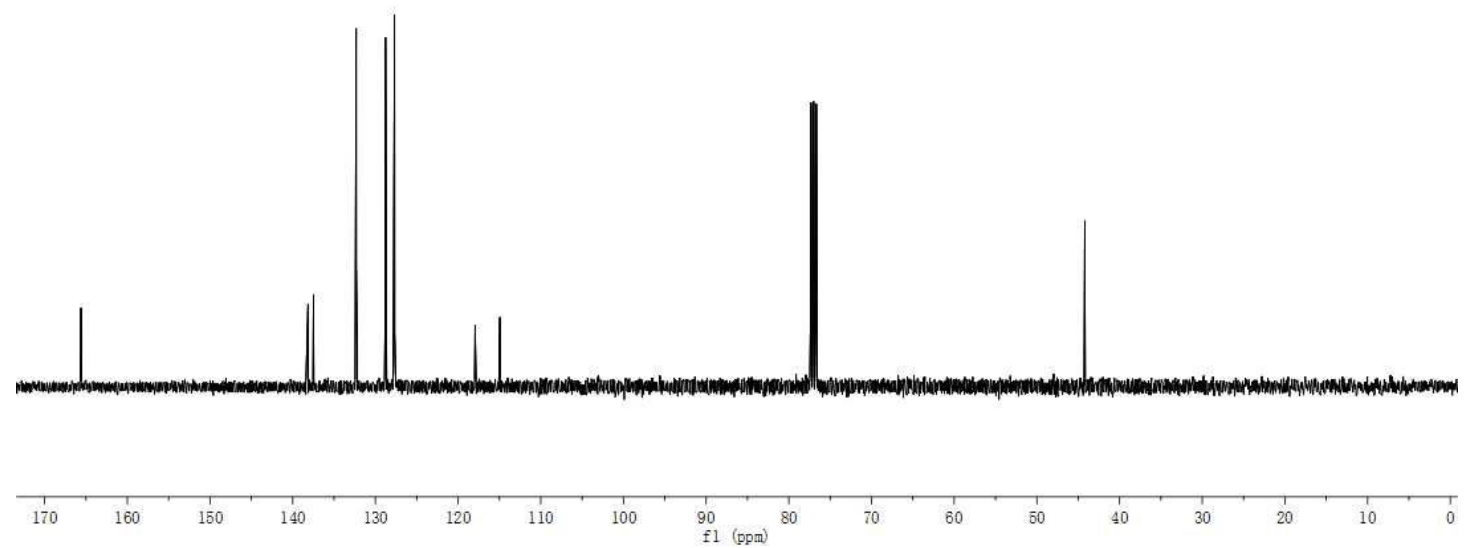

Figure S58. $100 \mathrm{MHz}{ }^{13} \mathrm{C}\left\{{ }^{1} \mathrm{H}\right\}$ NMR spectrum of $\mathbf{3 a c}$ in $\mathrm{CDCl}_{3}$. 


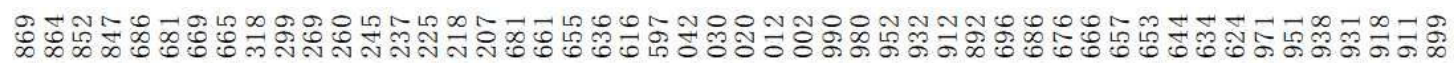

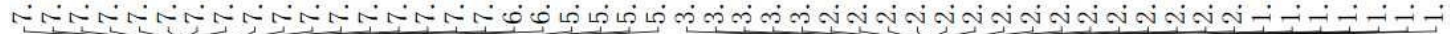

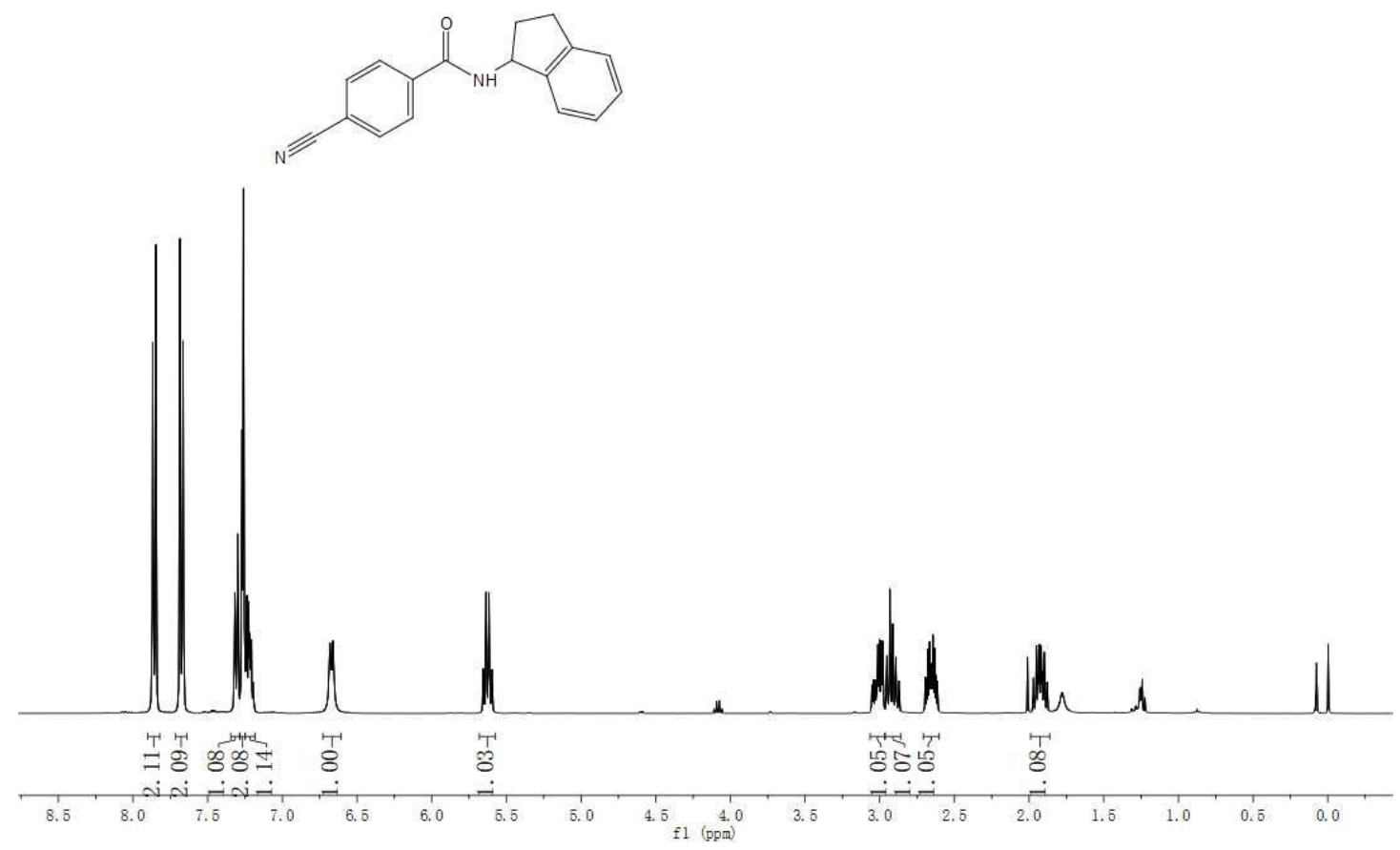

Figure S59. $400 \mathrm{MHz}{ }^{1} \mathrm{H}$ NMR spectrum of $\mathbf{3 a d}$ in $\mathrm{CDCl}_{3}$.

\begin{tabular}{|c|c|c|}
\hline 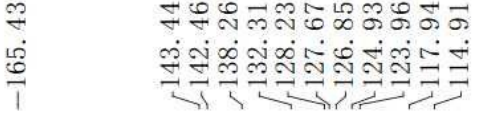 & 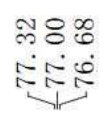 & 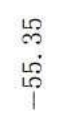 \\
\hline
\end{tabular}
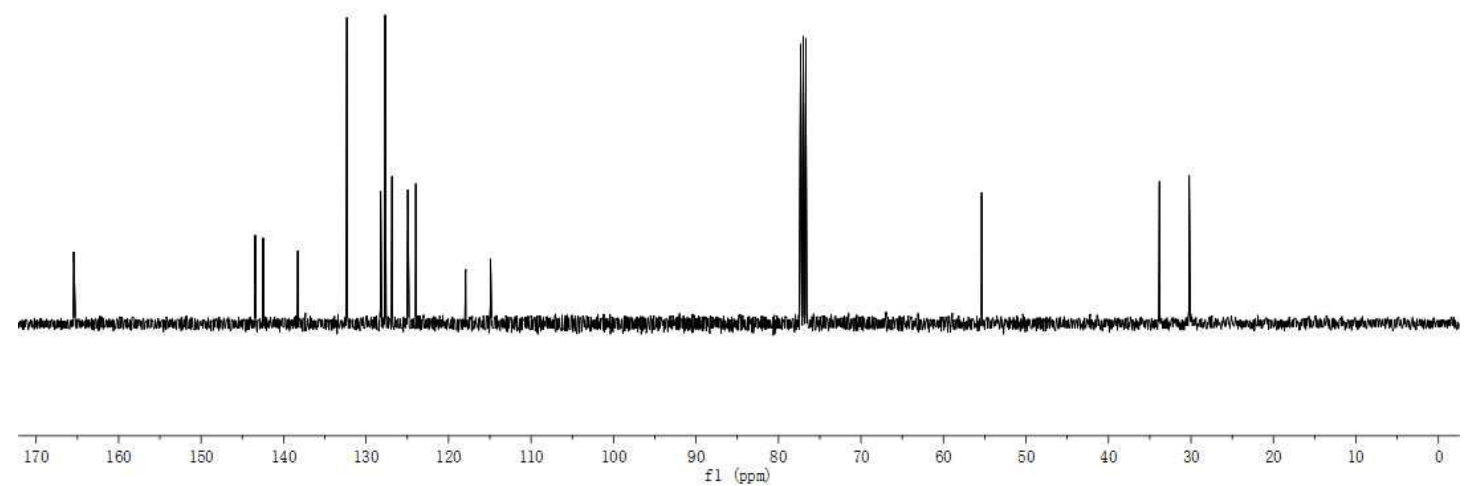

Figure $\mathbf{S 6 0} 100 \mathrm{MHz}{ }^{13} \mathrm{C}\left\{{ }^{1} \mathrm{H}\right\}$ NMR spectrum of $\mathbf{3 a d}$ in $\mathrm{CDCl}_{3}$. 

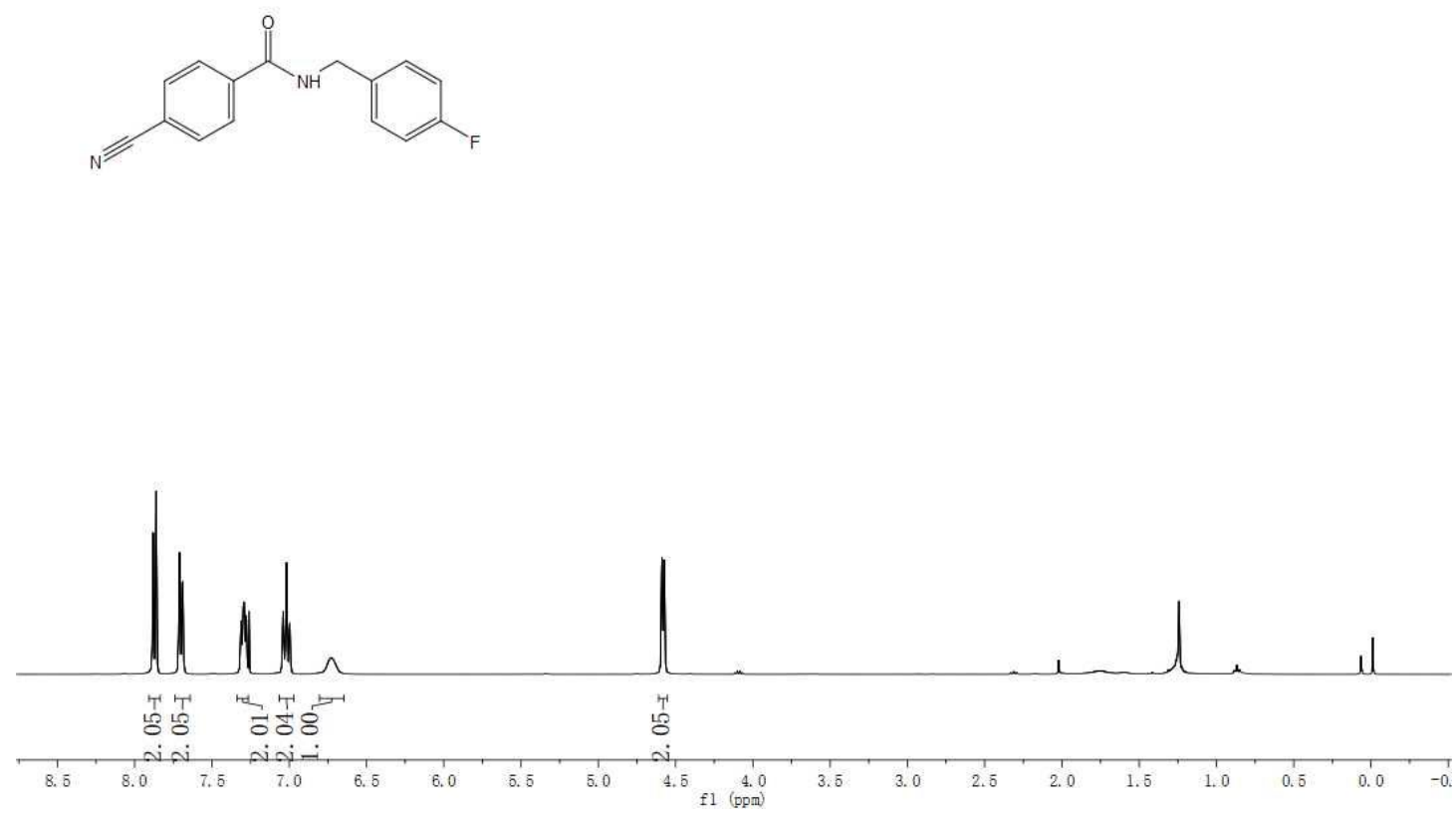

Figure S61. $400 \mathrm{MHz}{ }^{1} \mathrm{H}$ NMR spectrum of 3ae in $\mathrm{CDCl}_{3}$.

\begin{tabular}{|c|c|c|}
\hline 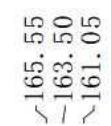 & 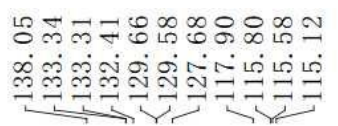 & 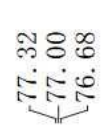 \\
\hline
\end{tabular}
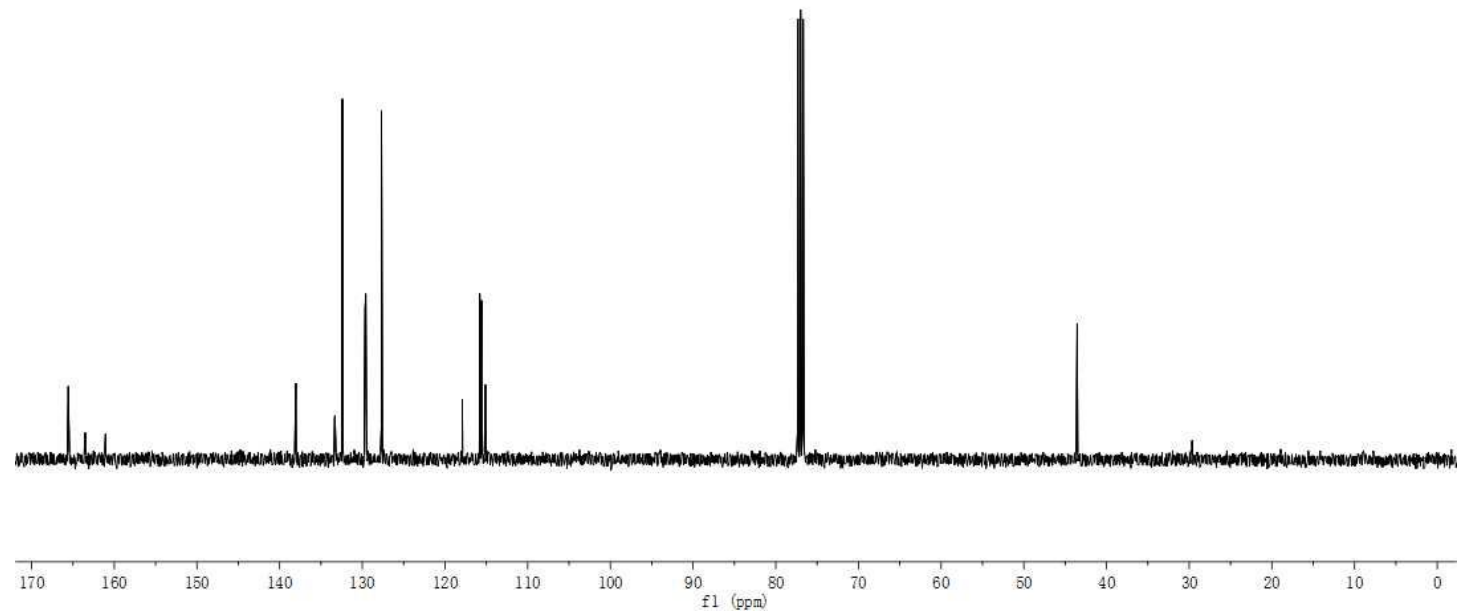

Figure $\mathbf{S 6 2} 100 \mathrm{MHz}{ }^{13} \mathrm{C}\left\{{ }^{1} \mathrm{H}\right\}$ NMR spectrum of $\mathbf{3 a e}$ in $\mathrm{CDCl}_{3}$. 

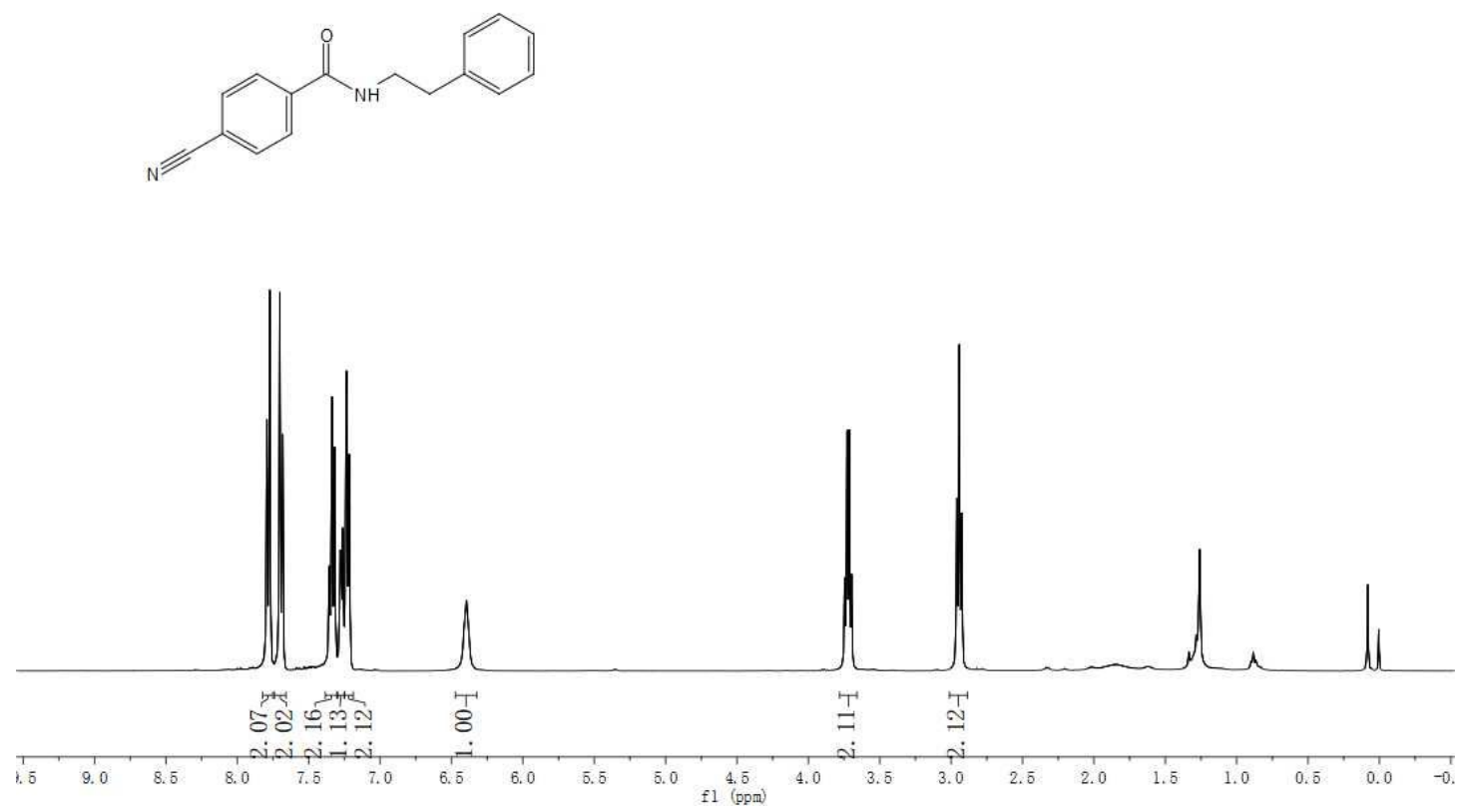

Figure S63. $400 \mathrm{MHz}{ }^{1} \mathrm{H}$ NMR spectrum of 3 af in $\mathrm{CDCl}_{3}$.

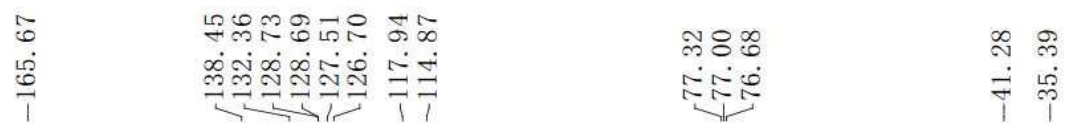
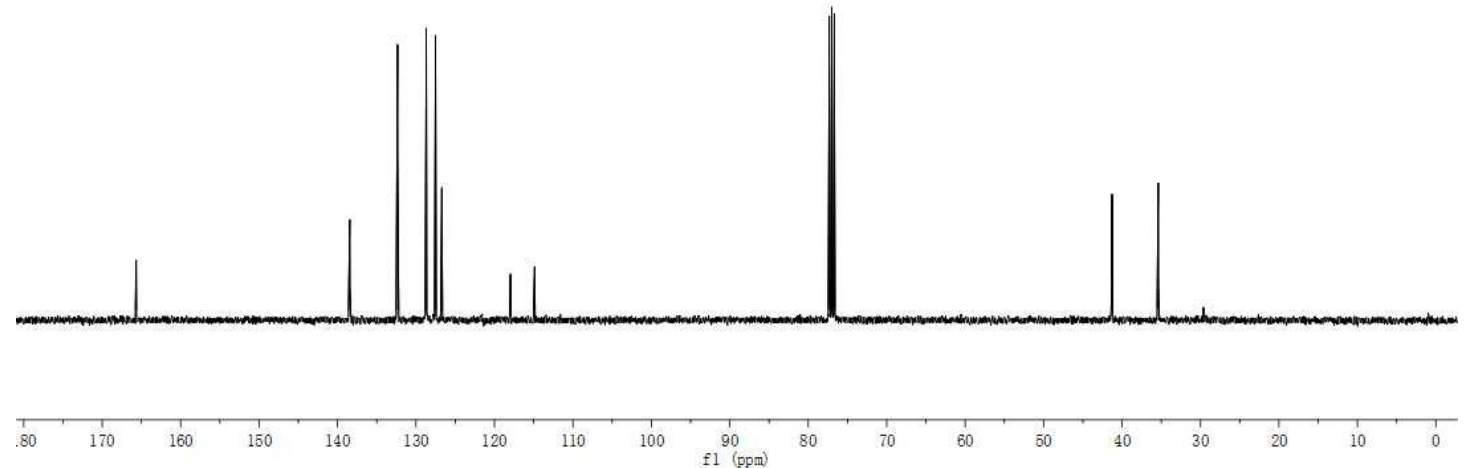

Figure S64 $100 \mathrm{MHz}{ }^{13} \mathrm{C}\left\{{ }^{1} \mathrm{H}\right\}$ NMR spectrum of $\mathbf{3 a f}$ in $\mathrm{CDCl}_{3}$. 
<smiles>CCCN(CCC)C(=O)c1ccc(C#N)cc1</smiles>

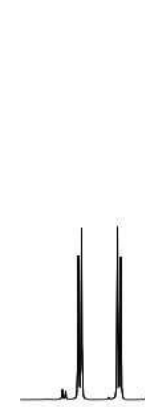

蕰

8. 0 i. ?

$7.5,7.0$

Figure $\mathbf{S 6 5} .400 \mathrm{MHz}{ }^{1} \mathrm{H}$ NMR spectrum of $\mathbf{3 a g}$ in $\mathrm{CDCl}_{3}$.

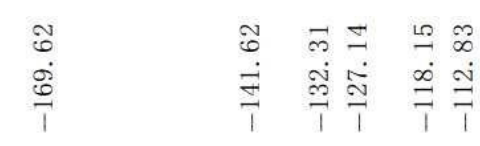

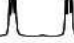

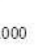




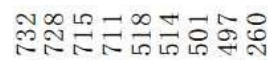

芯心去心

赵赵

भं⿰
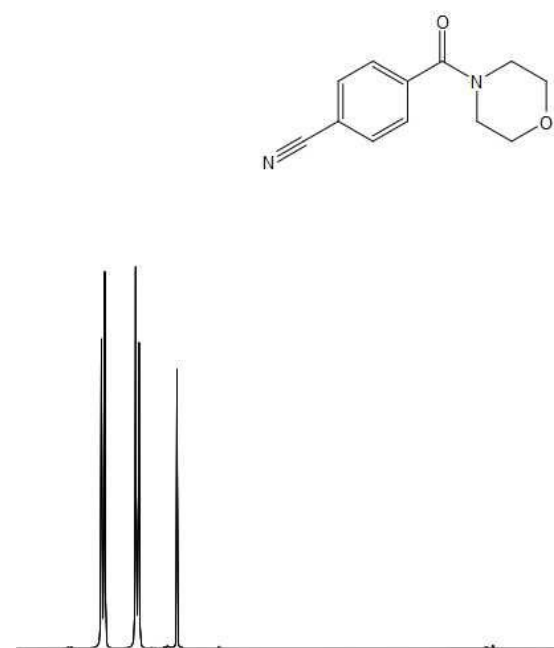

ำ ํำ
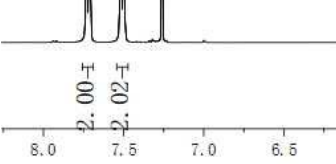

Figure S67. $400 \mathrm{MHz}{ }^{1} \mathrm{H}$ NMR spectrum of 3ah in $\mathrm{CDCl}_{3}$.

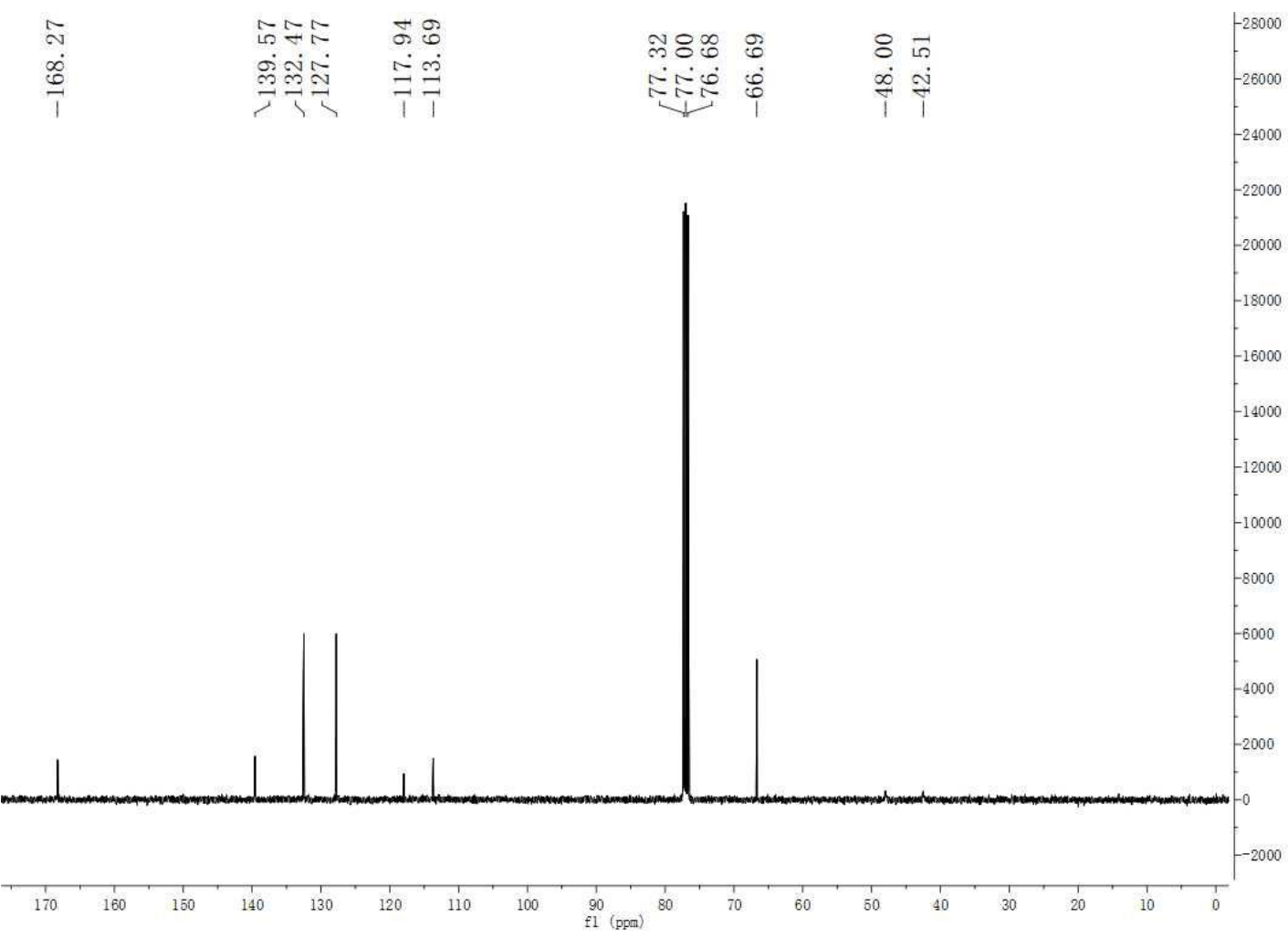

Figure S68 $100 \mathrm{MHz}{ }^{13} \mathrm{C}\left\{{ }^{1} \mathrm{H}\right\}$ NMR spectrum of 3ah in $\mathrm{CDCl}_{3}$. 

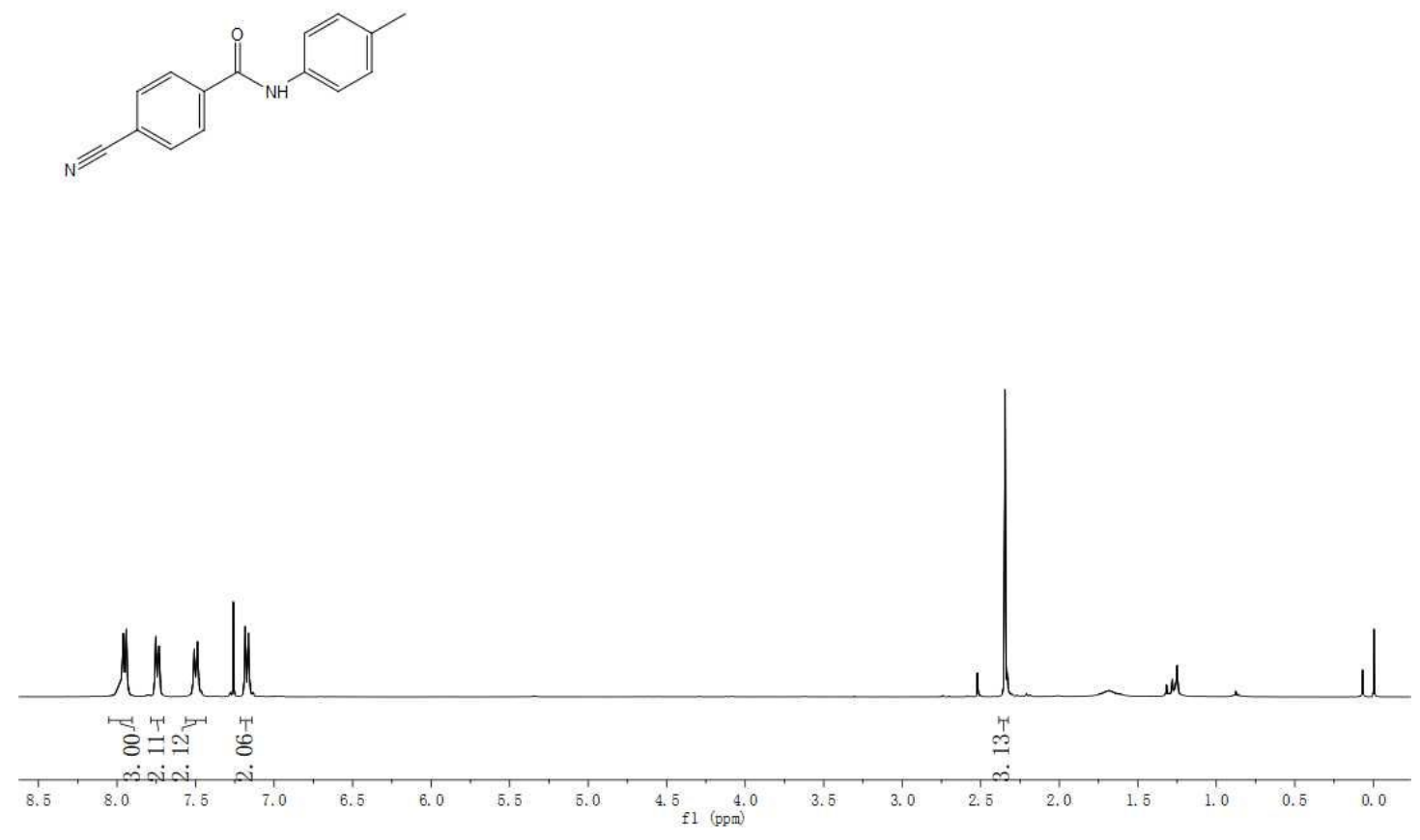

Figure S69. $400 \mathrm{MHz}{ }^{1} \mathrm{H}$ NMR spectrum of 3ai in $\mathrm{CDCl}_{3}$.

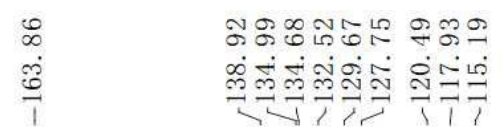

กิ8:

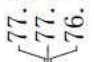

๙ั.
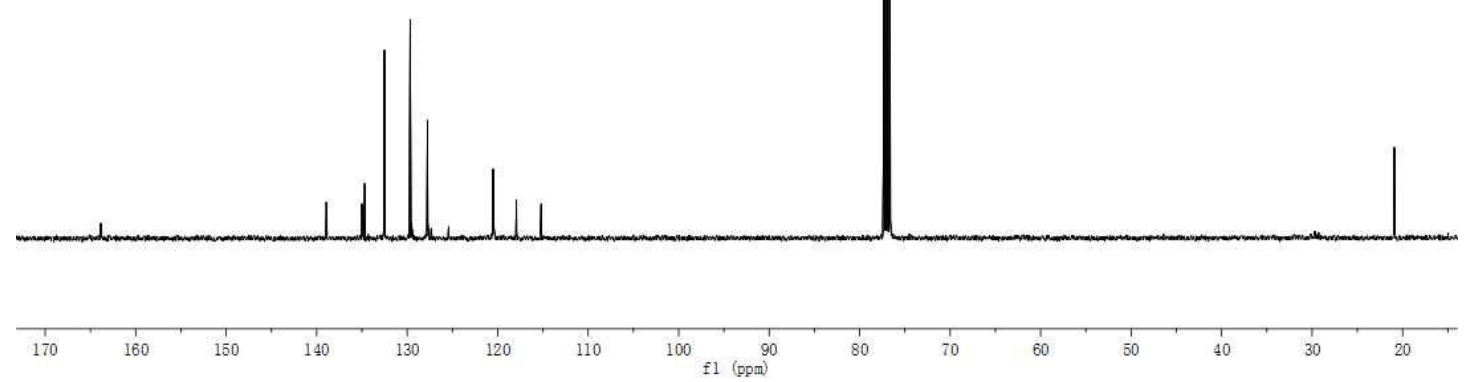

Figure S70 $100 \mathrm{MHz}{ }^{13} \mathrm{C}\left\{{ }^{1} \mathrm{H}\right\}$ NMR spectrum of 3ai in $\mathrm{CDCl}_{3}$. 


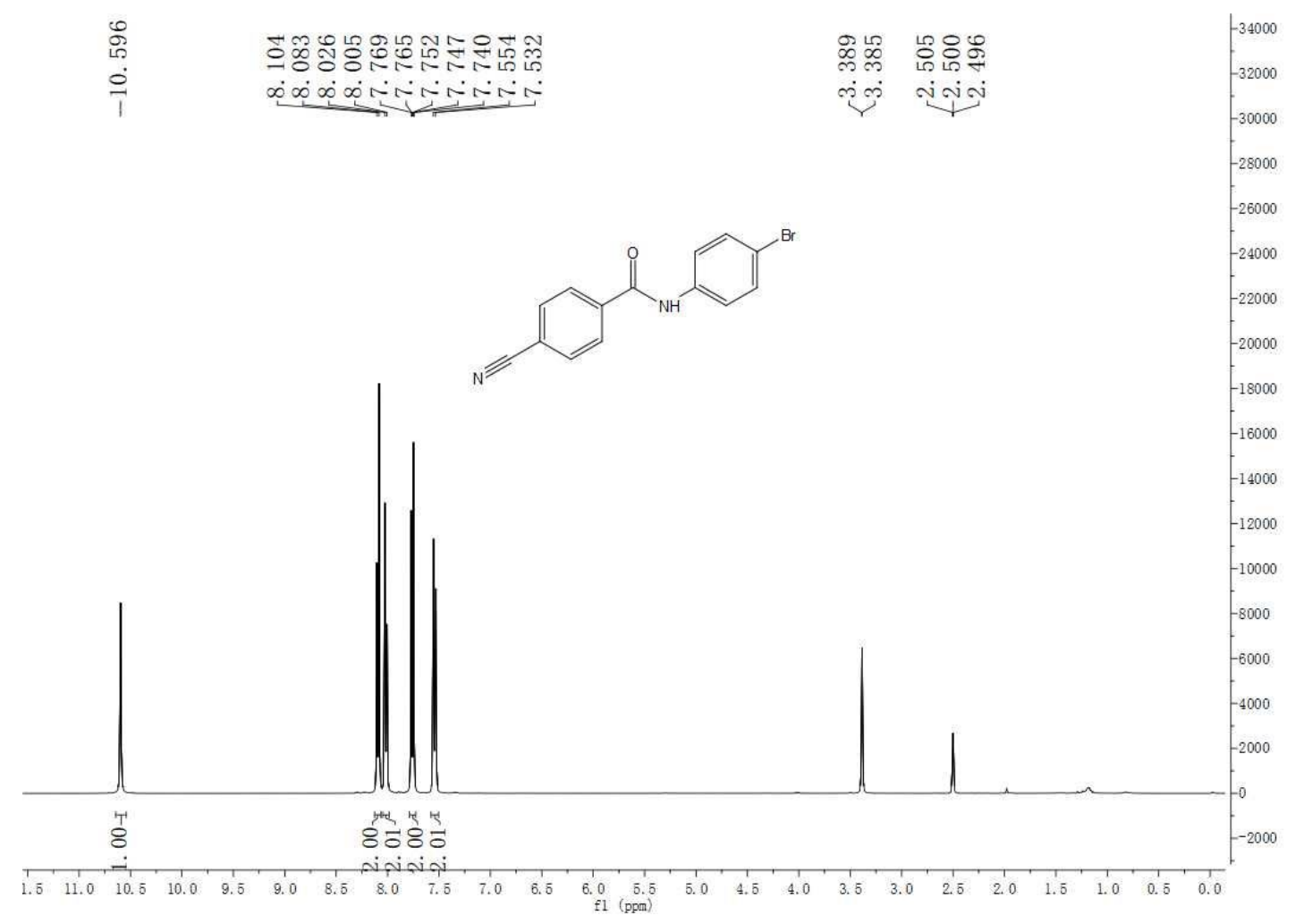

Figure S71. $400 \mathrm{MHz}{ }^{1} \mathrm{H}$ NMR spectrum of 3aj in DMSO-D 6 .

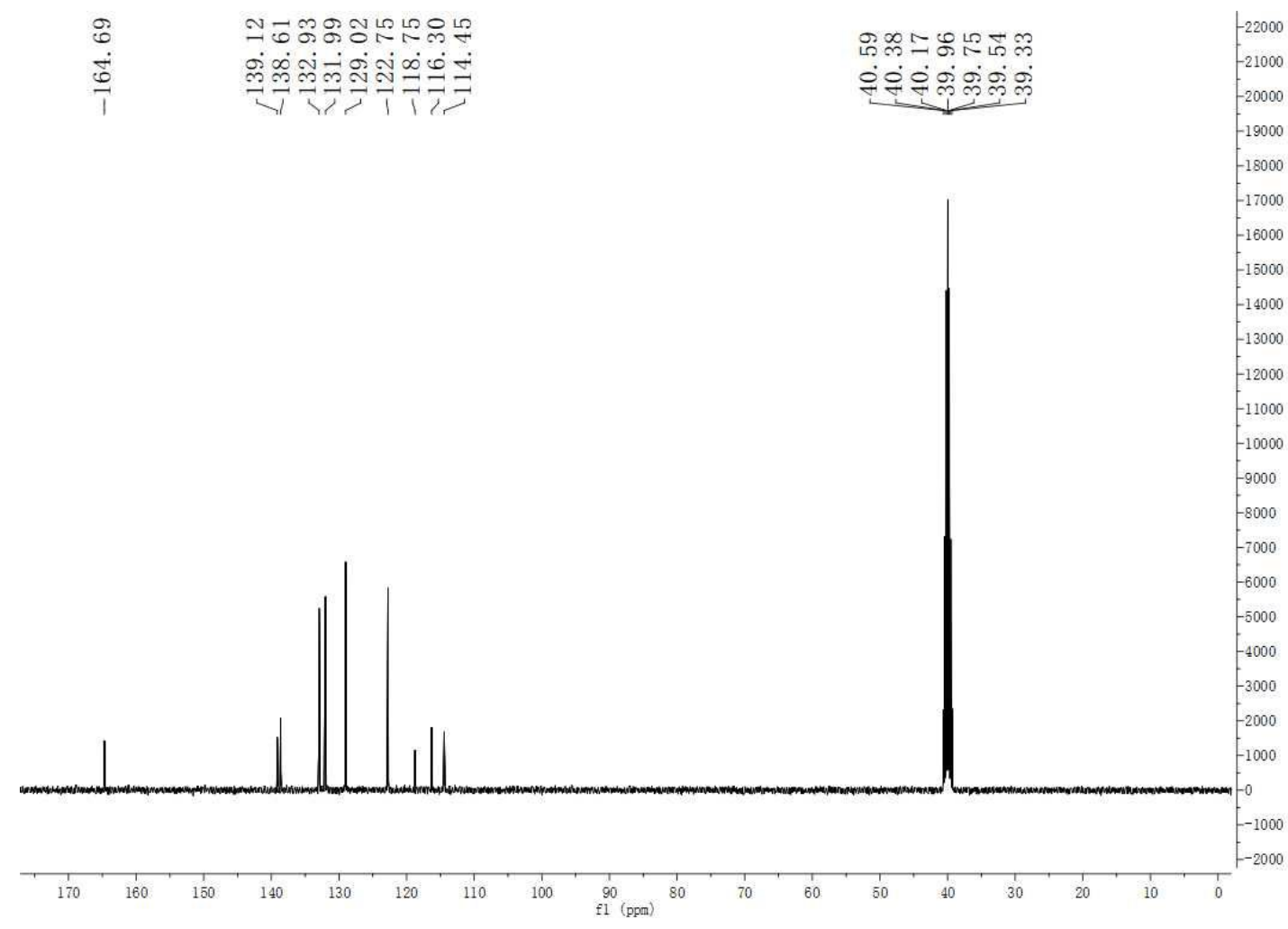

Figure S72. $100 \mathrm{MHz}{ }^{13} \mathrm{C}\left\{{ }^{1} \mathrm{H}\right\}$ NMR spectrum of 3aj in DMSO-D 6 . 
<smiles>Cc1ccc(NC(=O)c2cccc(C#N)c2)cc1</smiles>

|4.

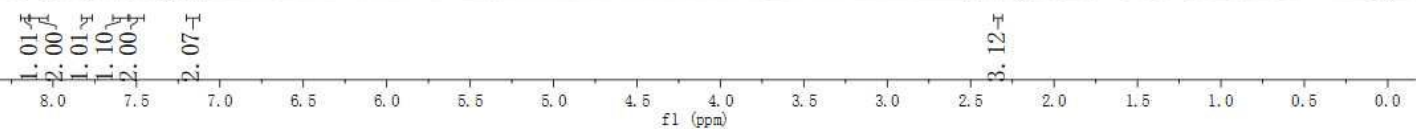

Figure S73. $400 \mathrm{MHz}{ }^{1} \mathrm{H}$ NMR spectrum of $\mathbf{3 a o}$ in $\mathrm{CDCl}_{3}$.

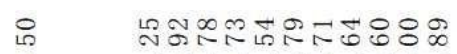

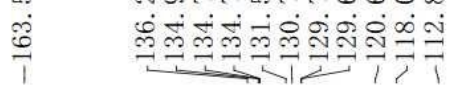

\section{ก้ะ 80}

穴完

के
ஸे

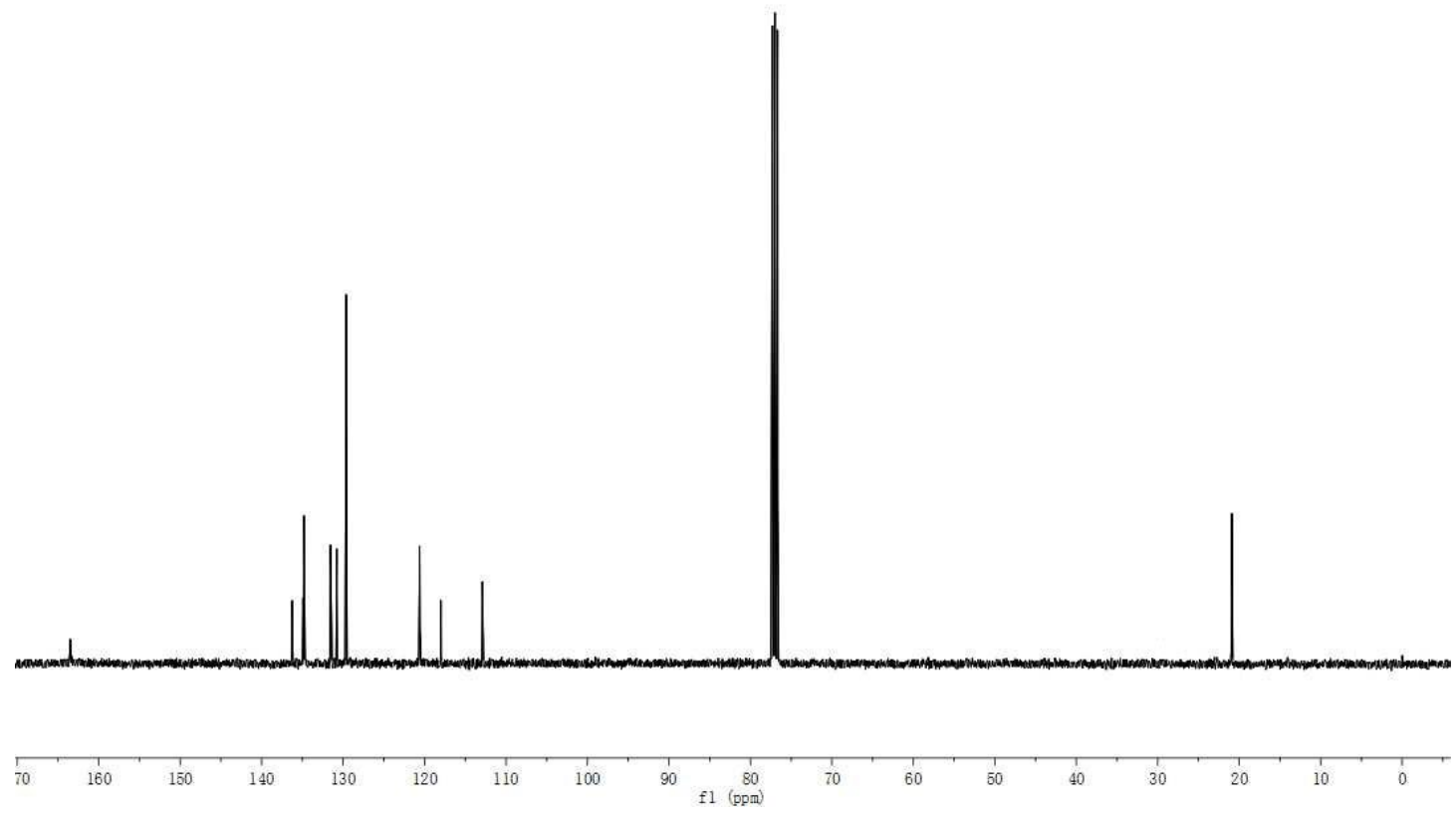

Figure $\mathbf{S 7 4} 100 \mathrm{MHz}{ }^{13} \mathrm{C}\left\{{ }^{1} \mathrm{H}\right\}$ NMR spectrum of $\mathbf{3 a o}$ in $\mathrm{CDCl}_{3}$. 

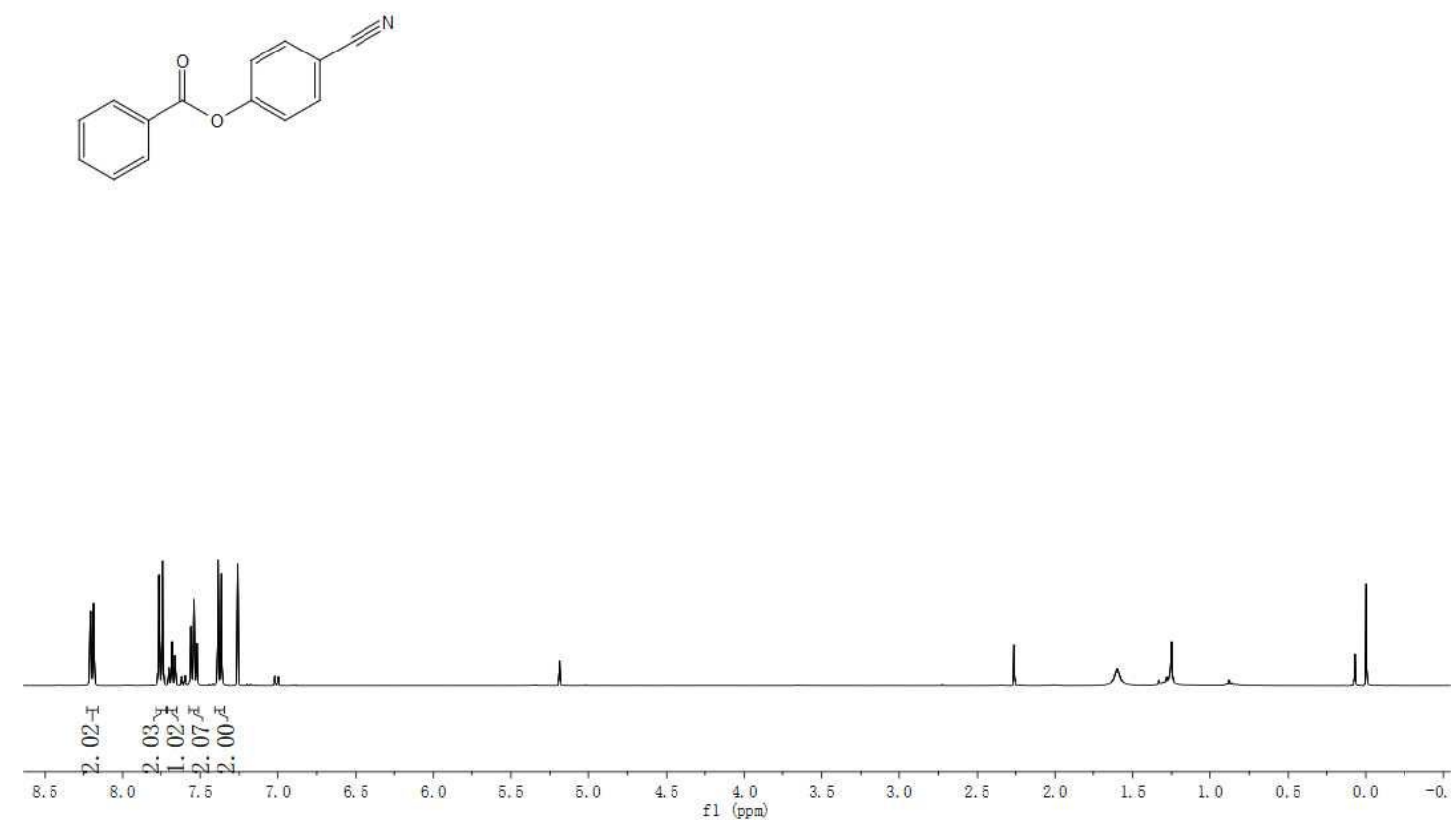

Figure S75. $400 \mathrm{MHz}{ }^{1} \mathrm{H}$ NMR spectrum of $\mathbf{4 a}$ in $\mathrm{CDCl}_{3}$.

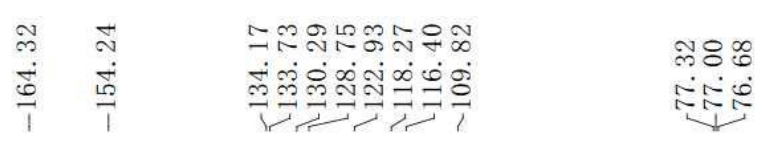

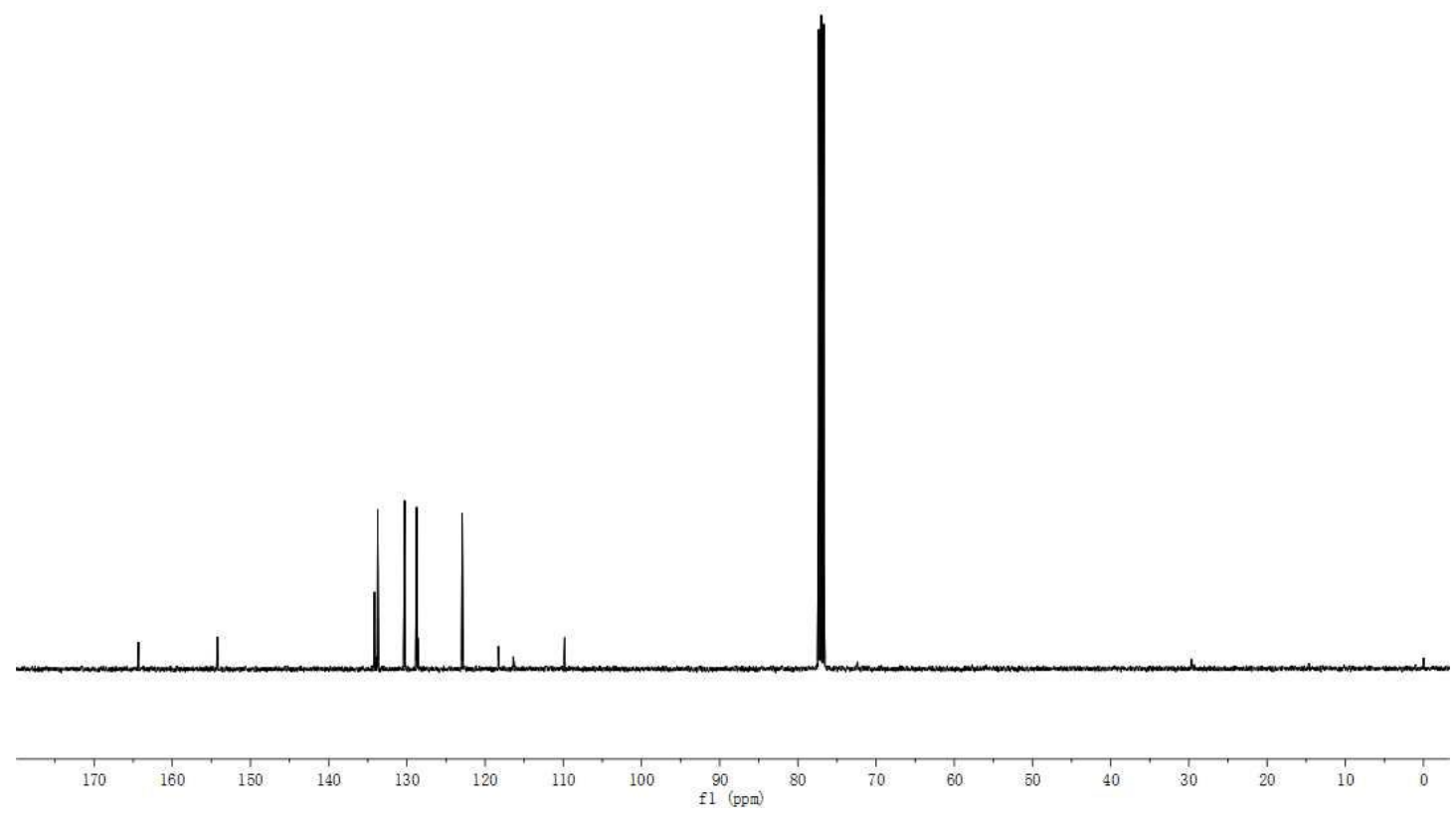

Figure $\mathbf{S 7 6} 100 \mathrm{MHz}{ }^{13} \mathrm{C}\left\{{ }^{1} \mathrm{H}\right\} \mathrm{NMR}$ spectrum of $\mathbf{4 a}$ in $\mathrm{CDCl}_{3}$. 


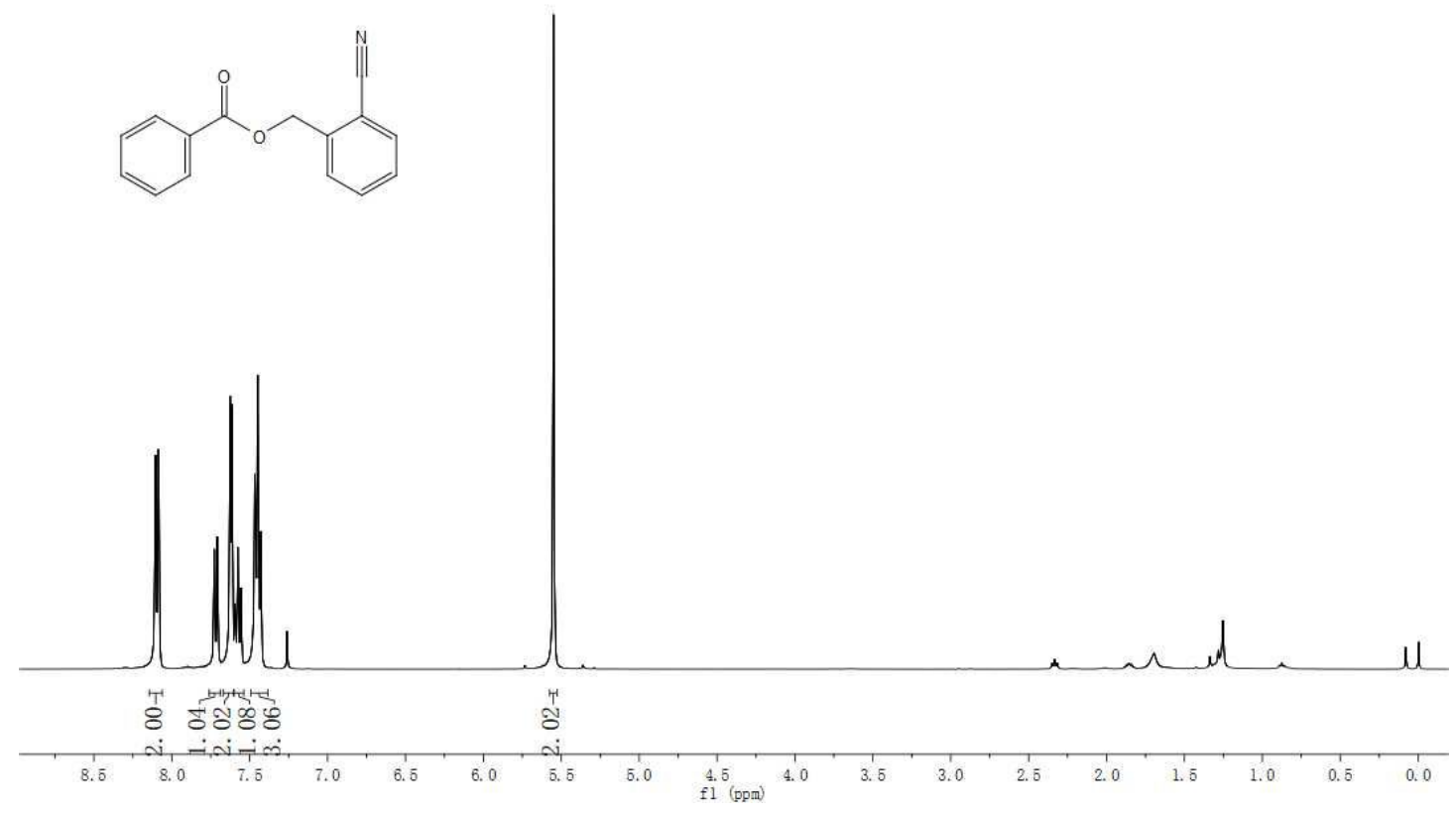

Figure $\mathbf{S 7 7} .400 \mathrm{MHz}{ }^{1} \mathrm{H}$ NMR spectrum of $\mathbf{4 b}$ in $\mathrm{CDCl}_{3}$.
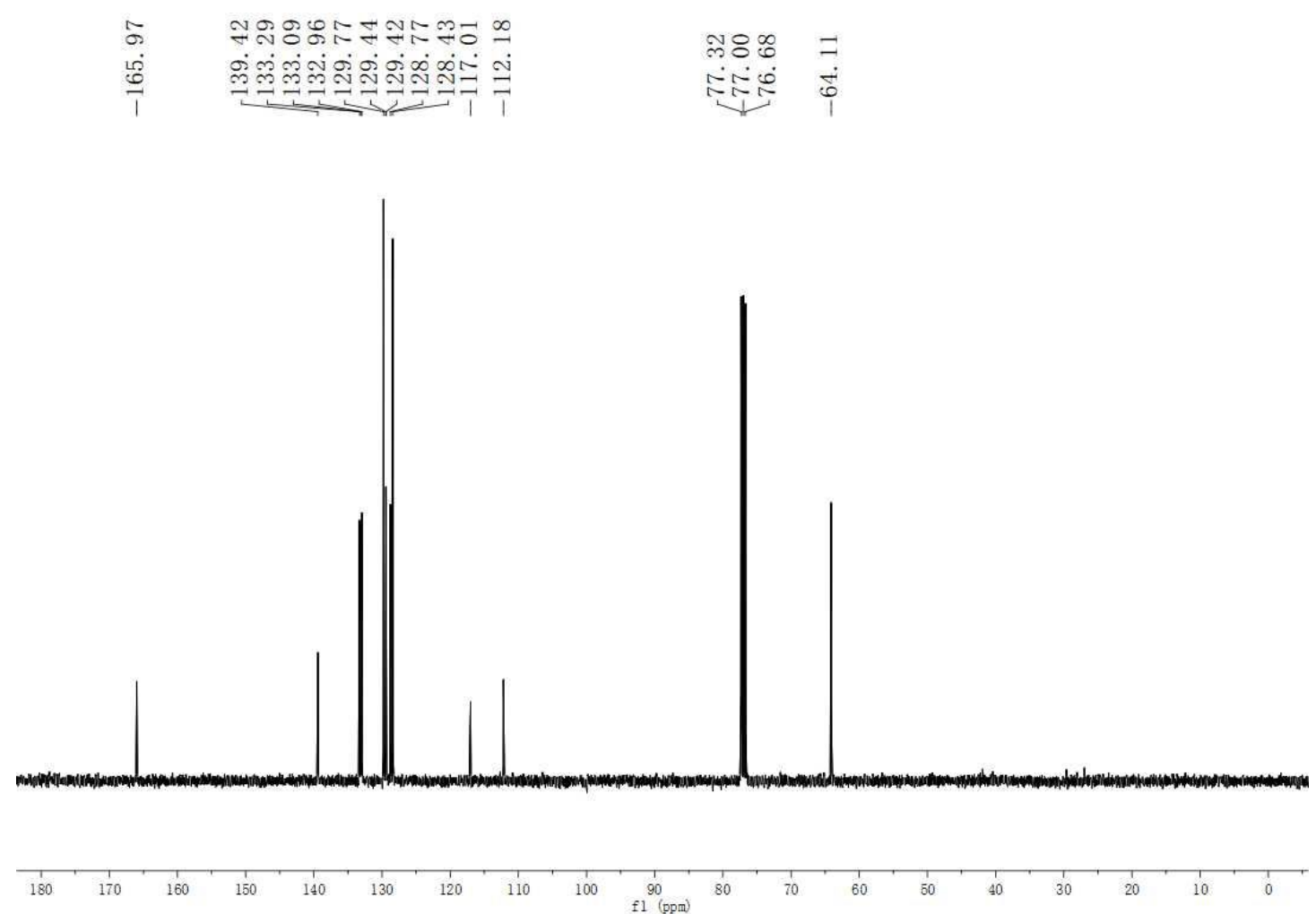

Figure $\mathbf{S 7 8} 100 \mathrm{MHz}{ }^{13} \mathrm{C}\left\{{ }^{1} \mathrm{H}\right\} \mathrm{NMR}$ spectrum of $\mathbf{4 b}$ in $\mathrm{CDCl}_{3}$. 

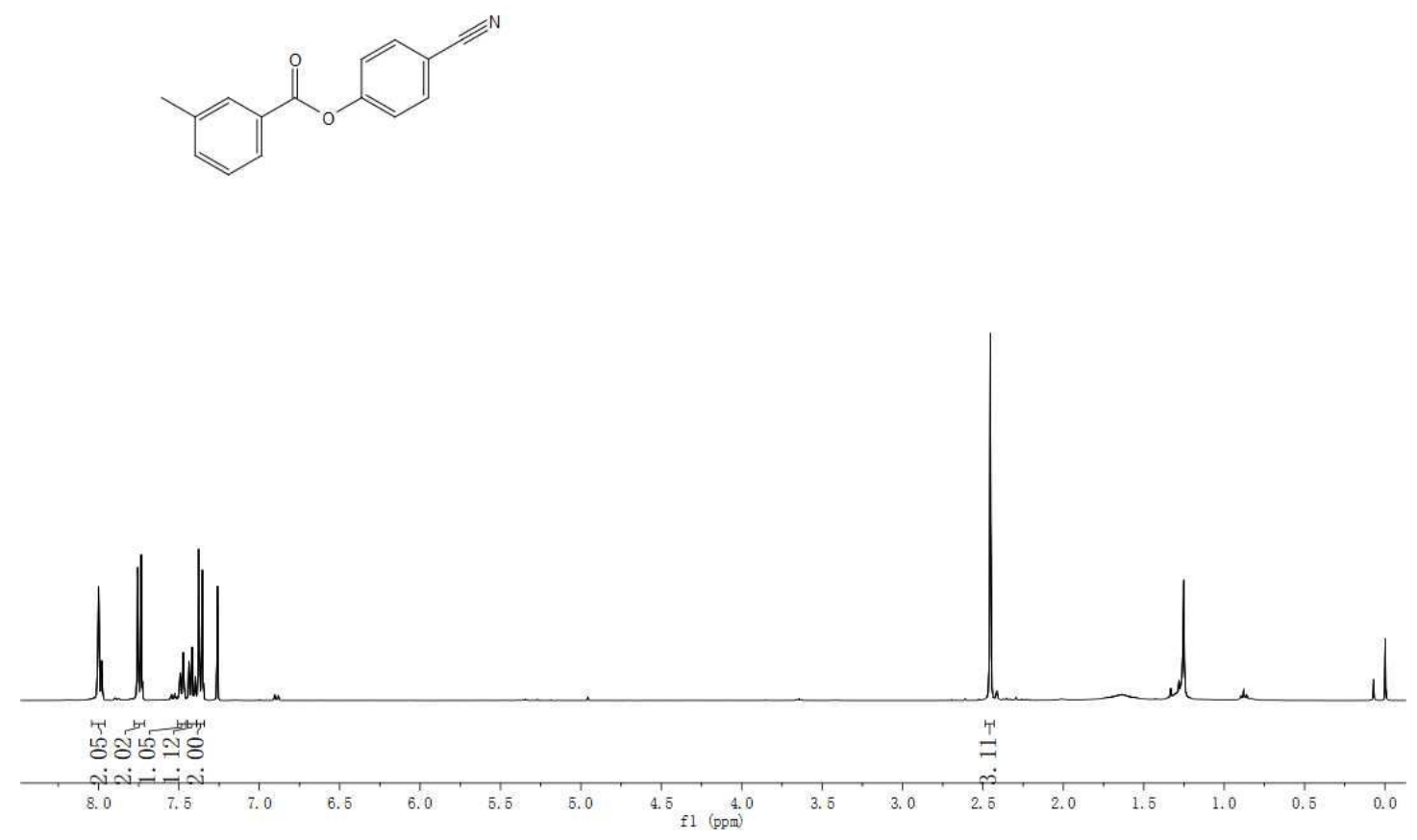

Figure S79. $400 \mathrm{MHz}{ }^{1} \mathrm{H}$ NMR spectrum of $4 \mathbf{c}$ in $\mathrm{CDCl}_{3}$.
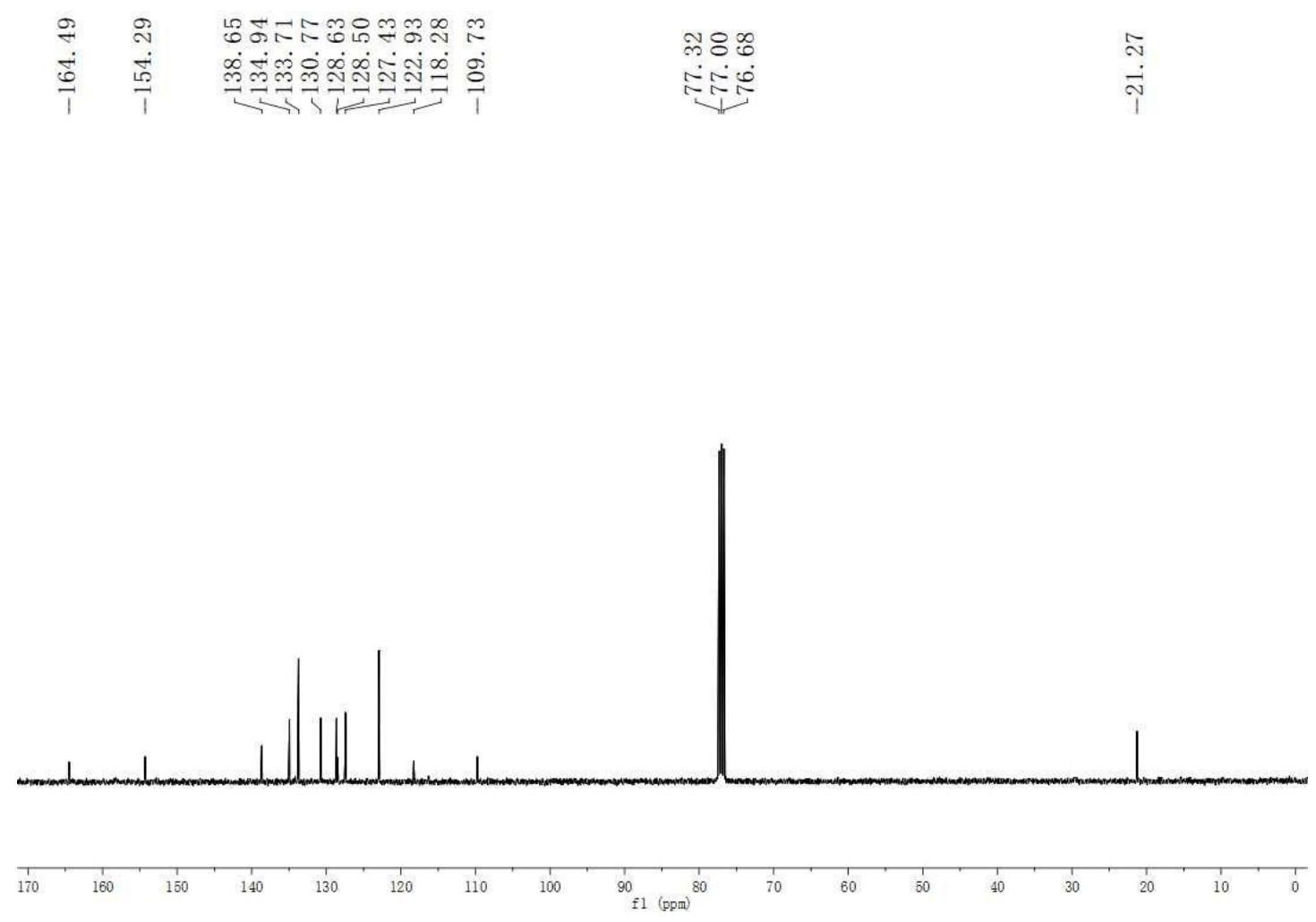

Figure $\mathbf{S 8 0} 100 \mathrm{MHz}{ }^{13} \mathrm{C}\left\{{ }^{1} \mathrm{H}\right\}$ NMR spectrum of $\mathbf{4 c}$ in $\mathrm{CDCl}_{3}$. 


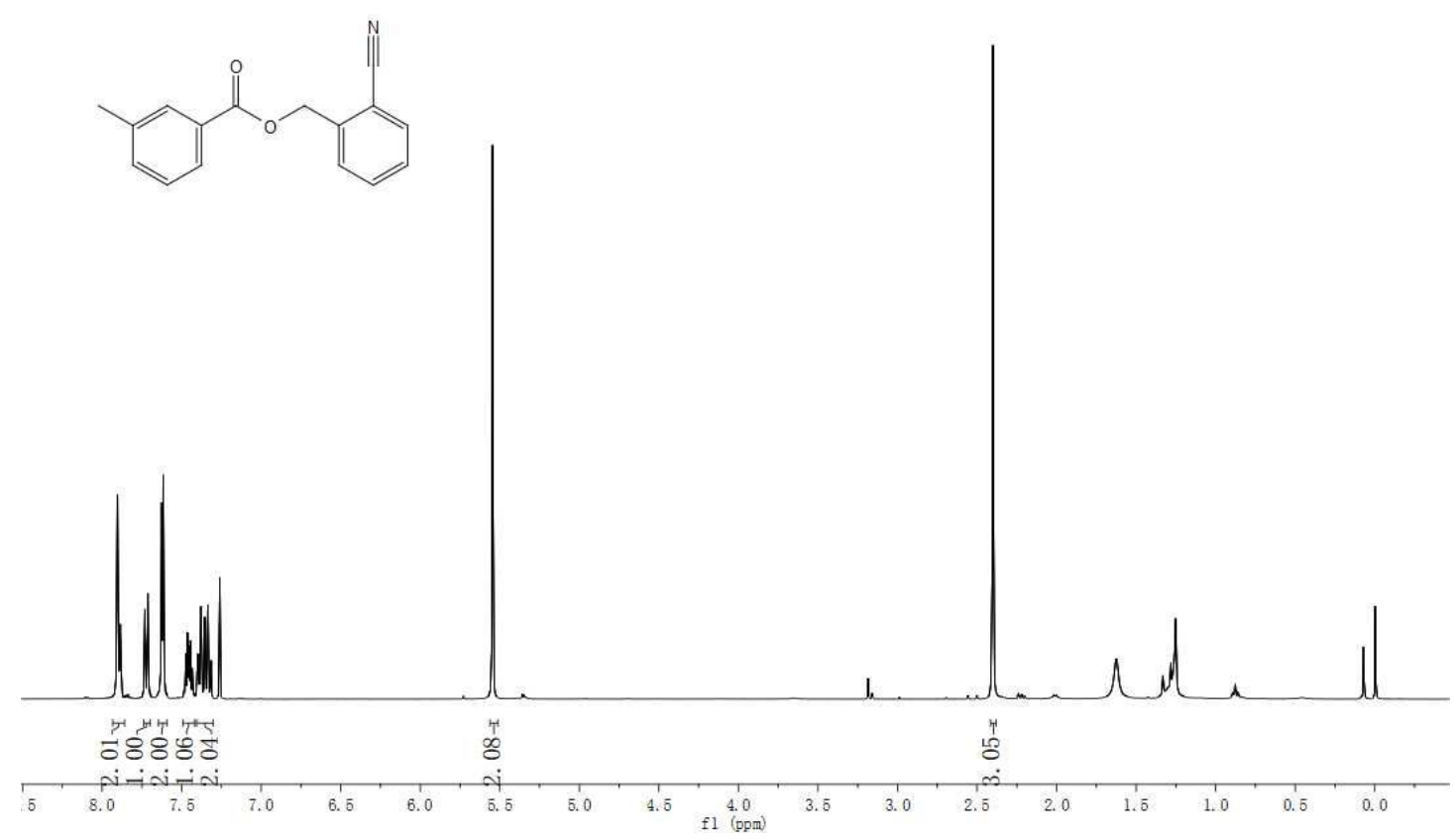

Figure S81. $400 \mathrm{MHz}{ }^{1} \mathrm{H}$ NMR spectrum of $\mathbf{4 d}$ in $\mathrm{CDCl}_{3}$.

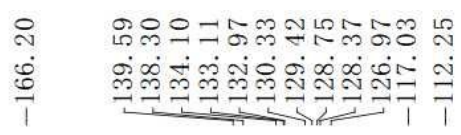

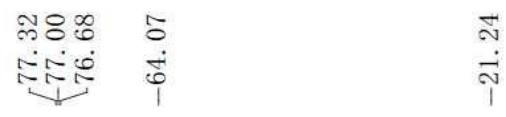

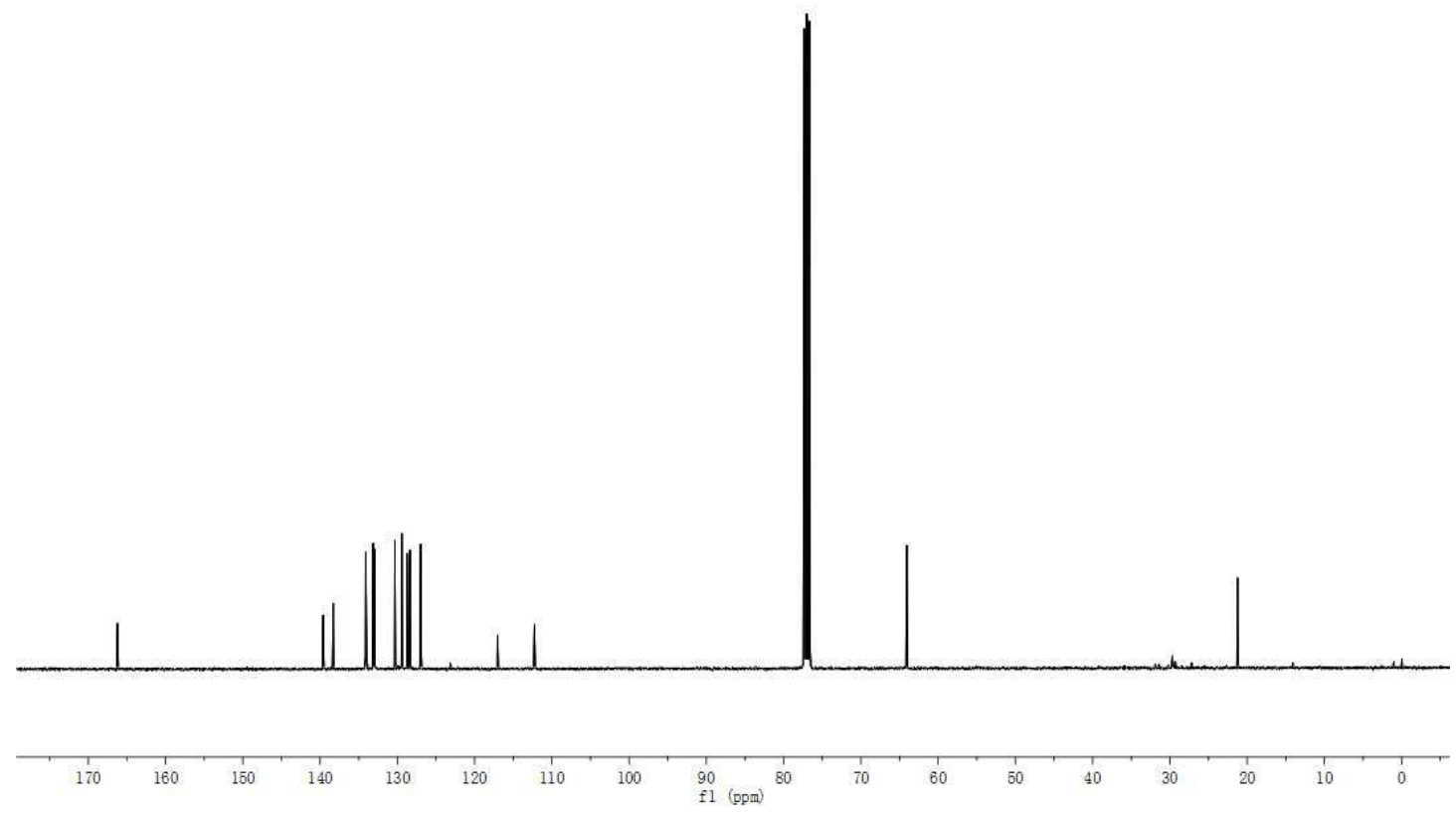

Figure S82 $100 \mathrm{MHz}{ }^{13} \mathrm{C}\left\{{ }^{1} \mathrm{H}\right\} \mathrm{NMR}$ spectrum of $\mathbf{4 d}$ in $\mathrm{CDCl}_{3}$. 
<smiles>CC(C)(C)c1ccc(C(=O)OCc2ccccc2C#N)cc1</smiles>

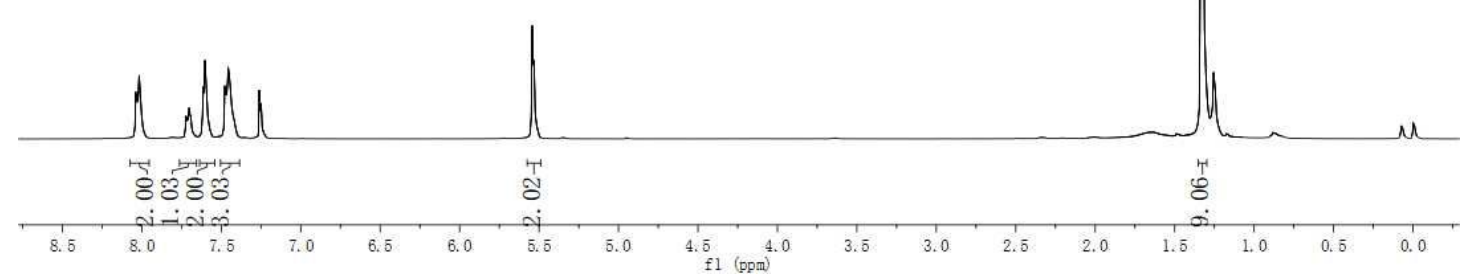

Figure S83. $400 \mathrm{MHz}{ }^{1} \mathrm{H}$ NMR spectrum of $4 \mathbf{e}$ in $\mathrm{CDCl}_{3}$.

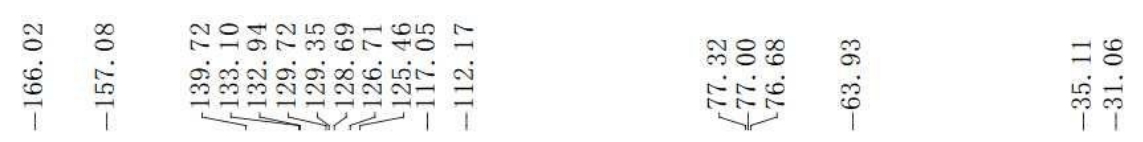
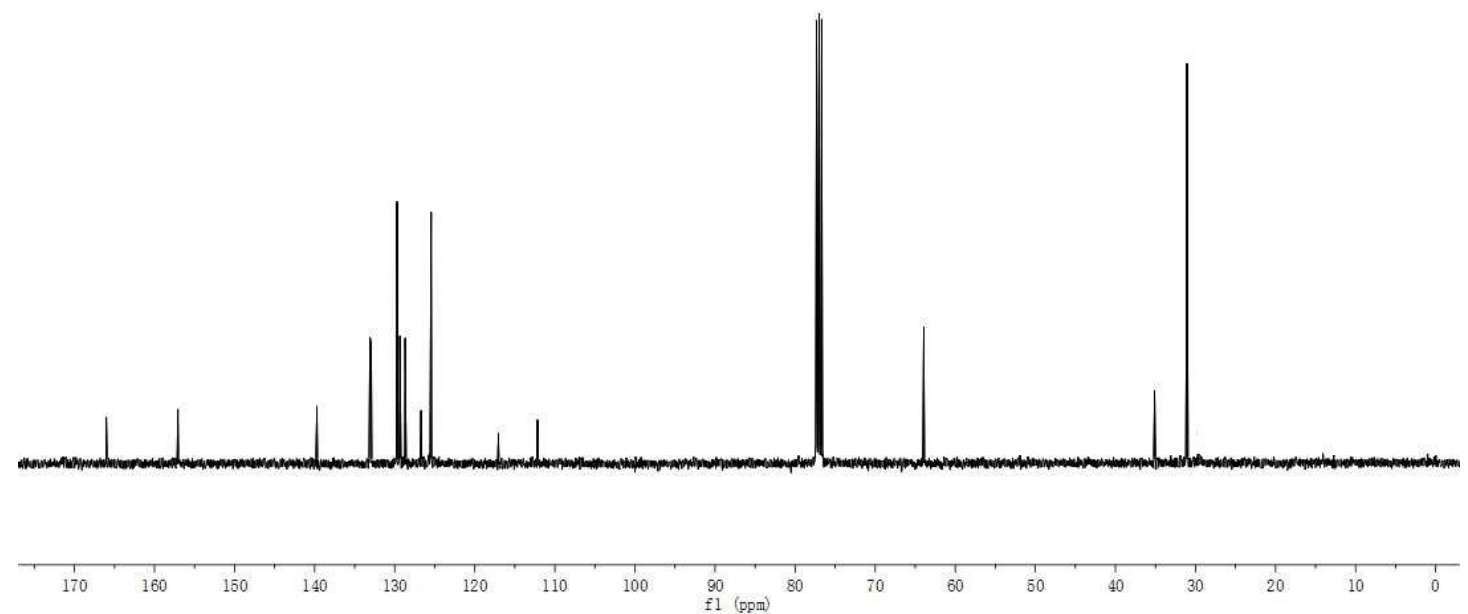

Figure $\mathbf{S 8 4} 100 \mathrm{MHz}{ }^{13} \mathrm{C}\left\{{ }^{1} \mathrm{H}\right\} \mathrm{NMR}$ spectrum of $4 \mathbf{e}$ in $\mathrm{CDCl}_{3}$. 


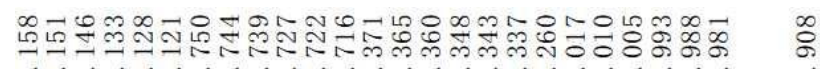

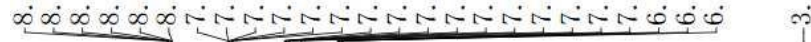

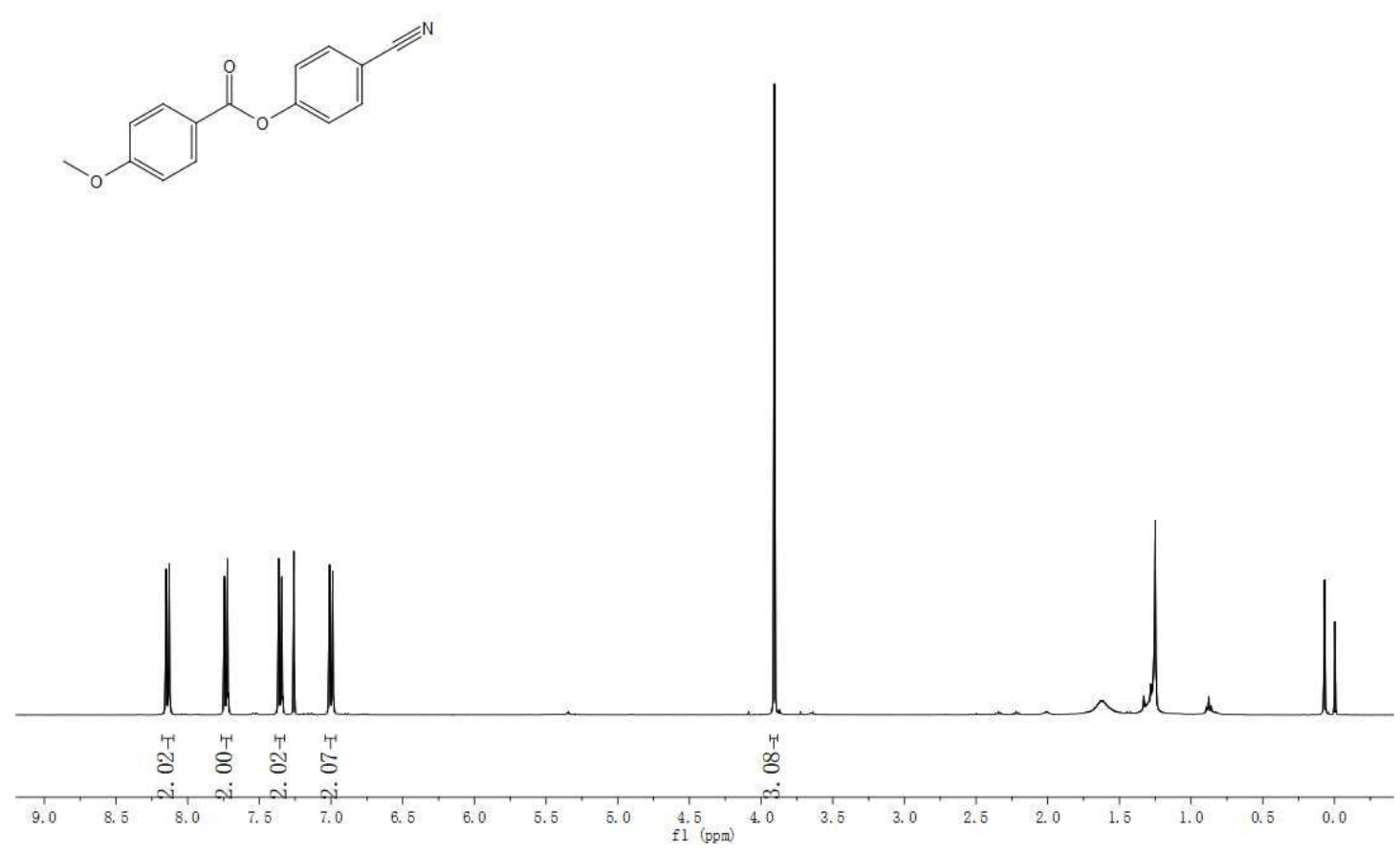

Figure S85. $400 \mathrm{MHz}{ }^{1} \mathrm{H}$ NMR spectrum of $\mathbf{4} \mathbf{f}$ in $\mathrm{CDCl}_{3}$.

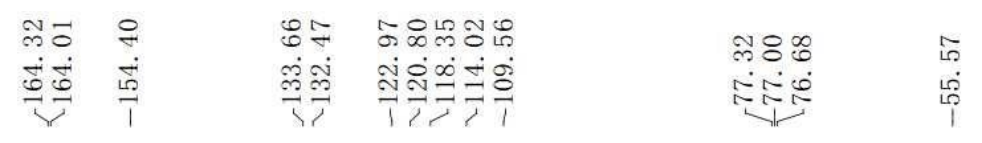

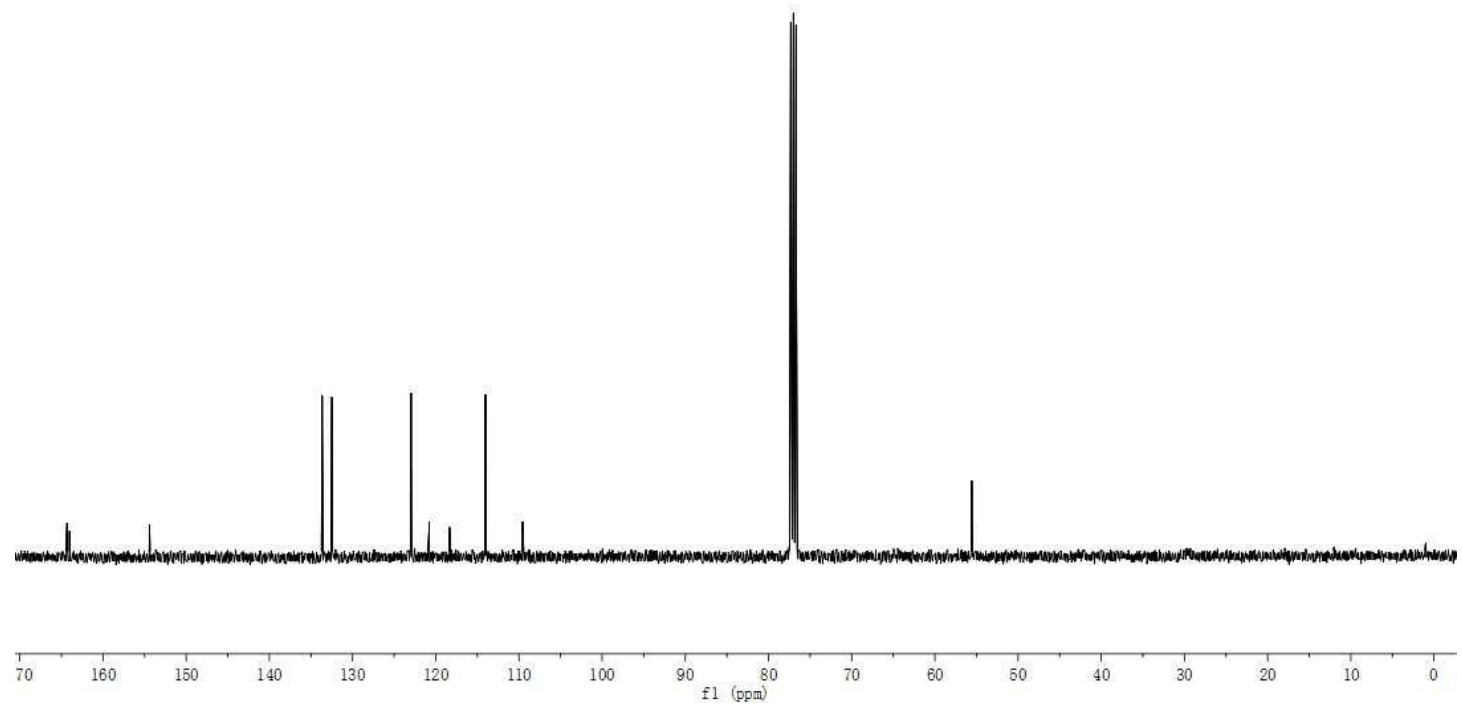

Figure $\mathbf{S 8 6} 100 \mathrm{MHz}{ }^{13} \mathrm{C}\left\{{ }^{1} \mathrm{H}\right\}$ NMR spectrum of $\mathbf{4 f}$ in $\mathrm{CDCl}_{3}$. 


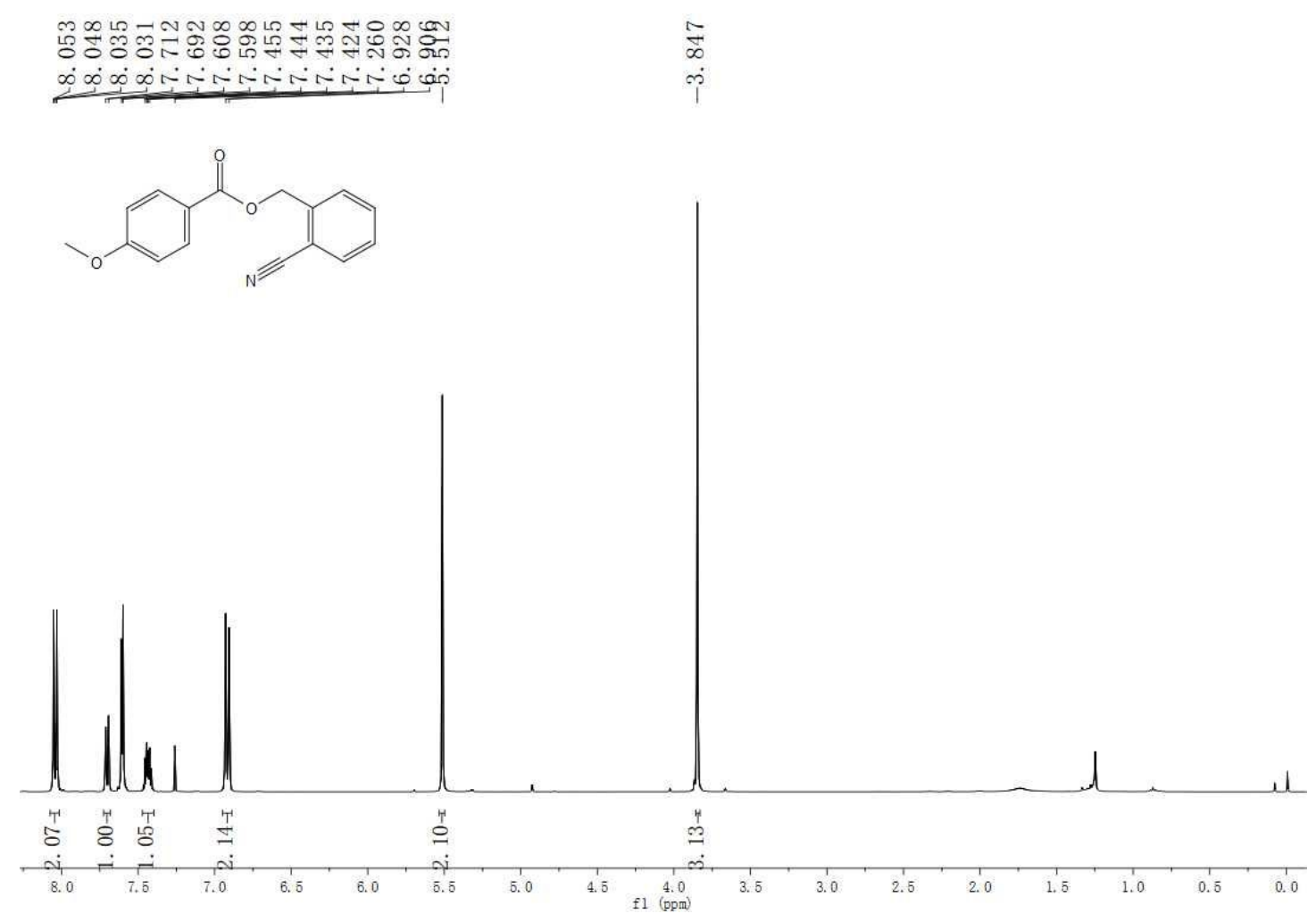

Figure S87. $400 \mathrm{MHz}{ }^{1} \mathrm{H}$ NMR spectrum of $\mathbf{4 g}$ in $\mathrm{CDCl}_{3}$.

\begin{tabular}{|c|c|c|}
\hline $\begin{array}{l}\infty: 8 \\
0: 0 \\
\dot{0} 0 \\
10 \\
1\end{array}$ & 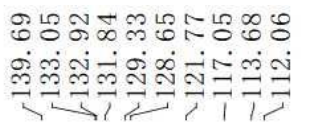 & $\begin{array}{l}\text { กै8\% } \\
\text { 숭 }\end{array}$ \\
\hline
\end{tabular}
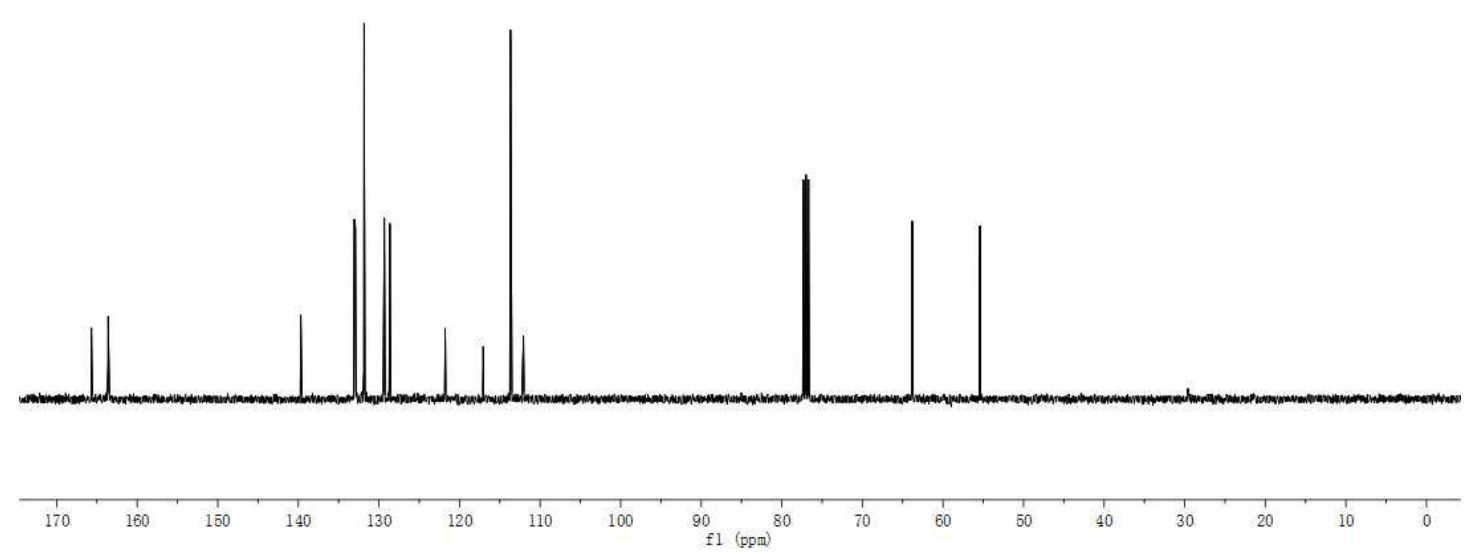

Figure $\mathbf{S 8 8} 100 \mathrm{MHz}{ }^{13} \mathrm{C}\left\{{ }^{1} \mathrm{H}\right\}$ NMR spectrum of $\mathbf{4 g}$ in $\mathrm{CDCl}_{3}$. 


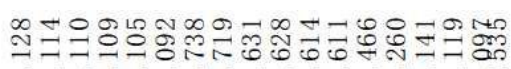

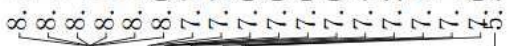
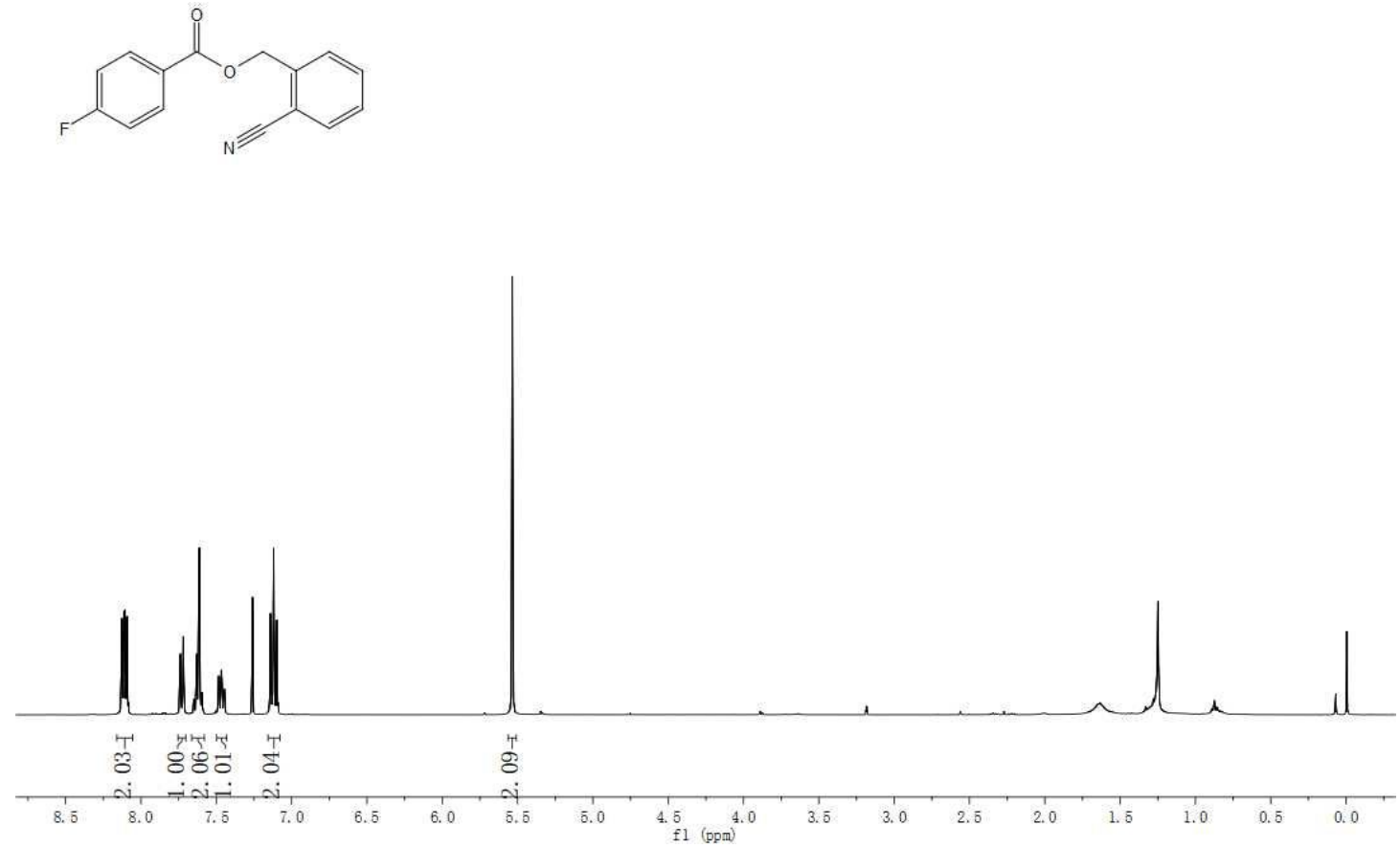

Figure S89. $400 \mathrm{MHz}{ }^{1} \mathrm{H}$ NMR spectrum of $\mathbf{4 h}$ in $\mathrm{CDCl}_{3}$.

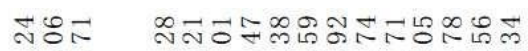

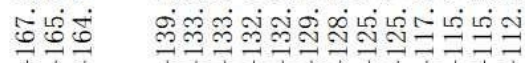

กิ8: लै

추 完

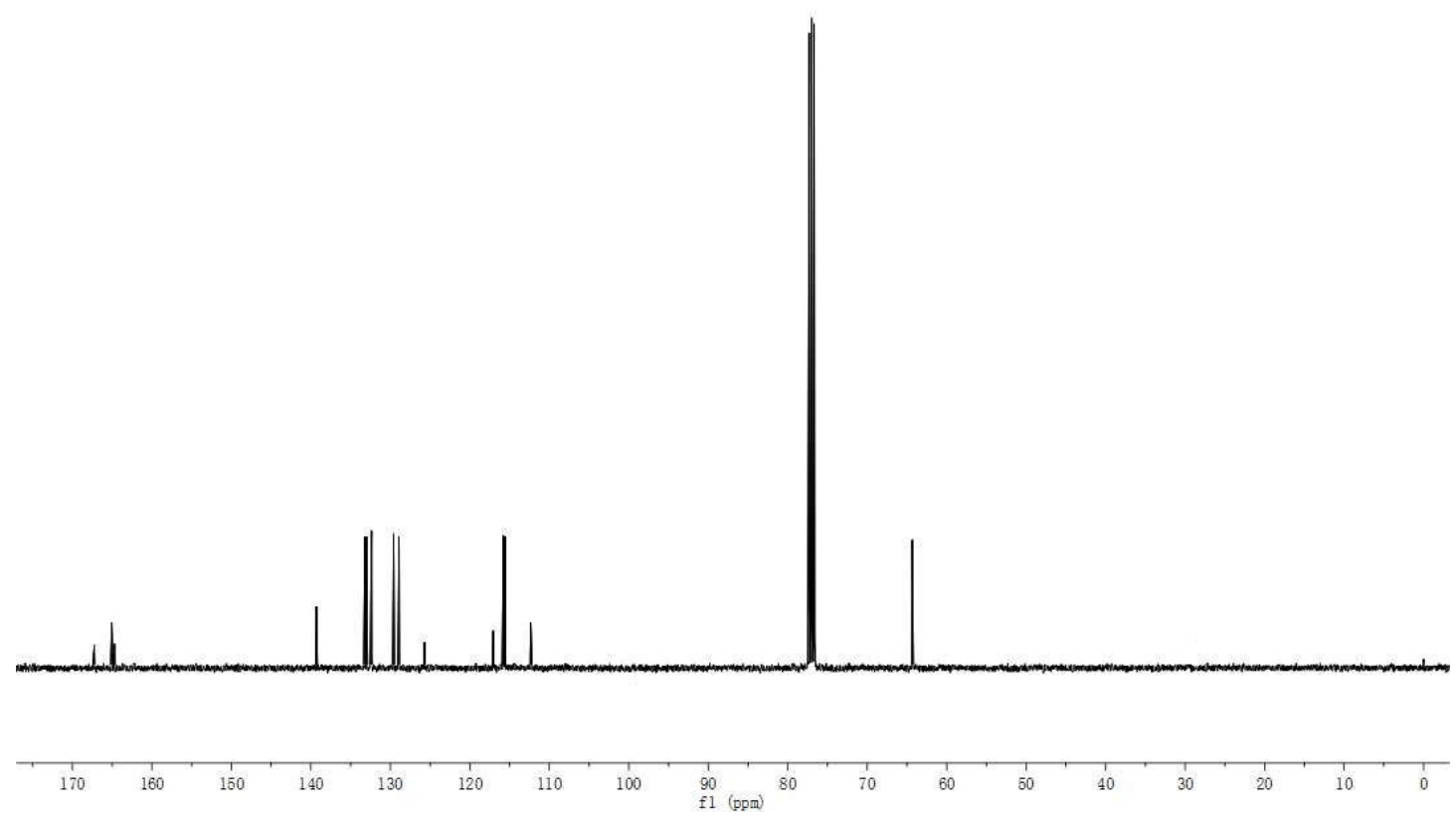

Figure $\mathbf{S 9 0} 100 \mathrm{MHz}{ }^{13} \mathrm{C}\left\{{ }^{1} \mathrm{H}\right\}$ NMR spectrum of $\mathbf{4 h}$ in $\mathrm{CDCl}_{3}$. 


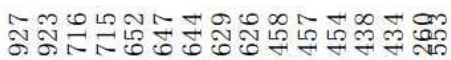

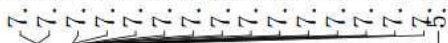

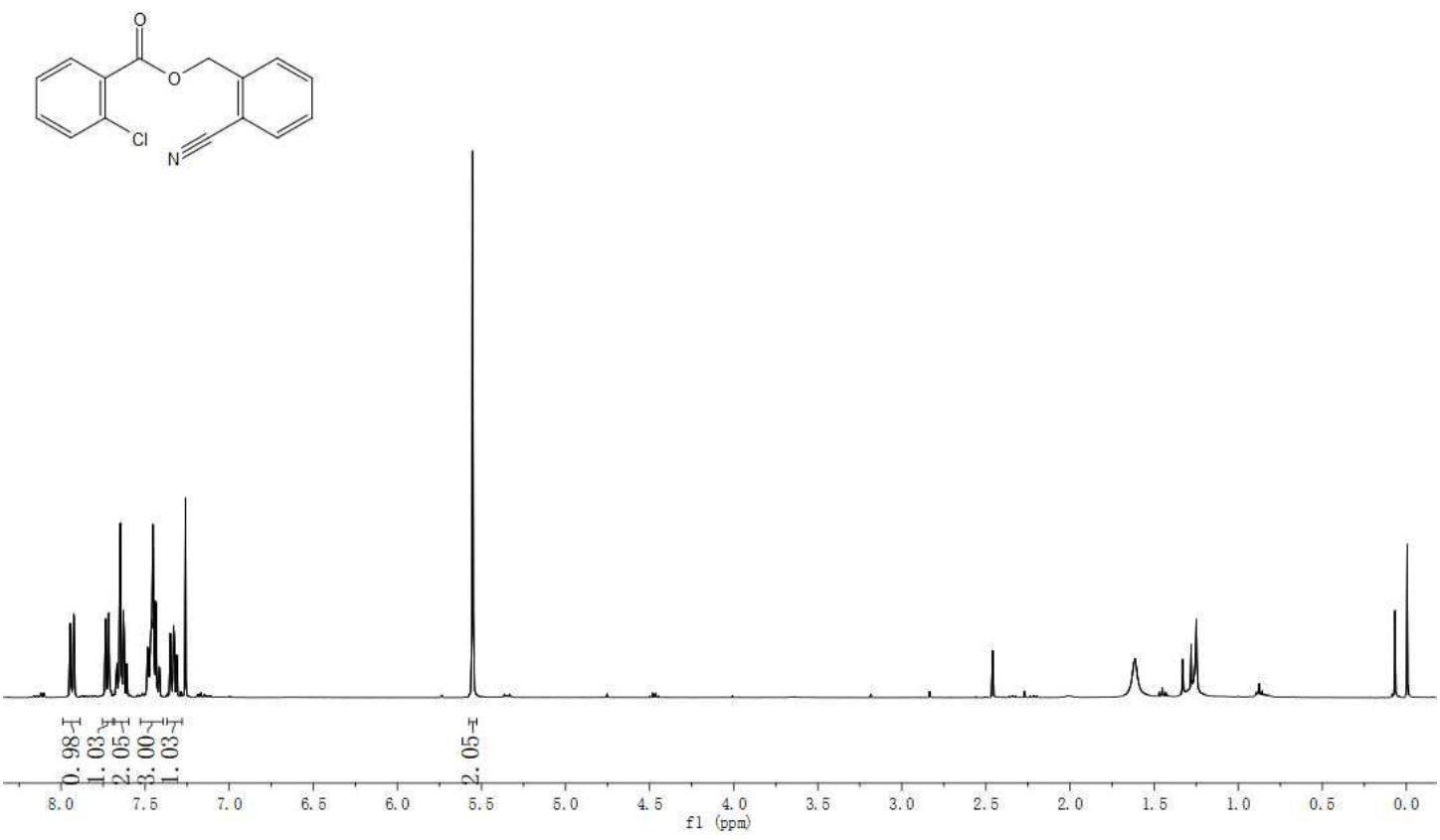

Figure S91. $400 \mathrm{MHz}{ }^{1} \mathrm{H}$ NMR spectrum of $4 \mathbf{i}$ in $\mathrm{CDCl}_{3}$.
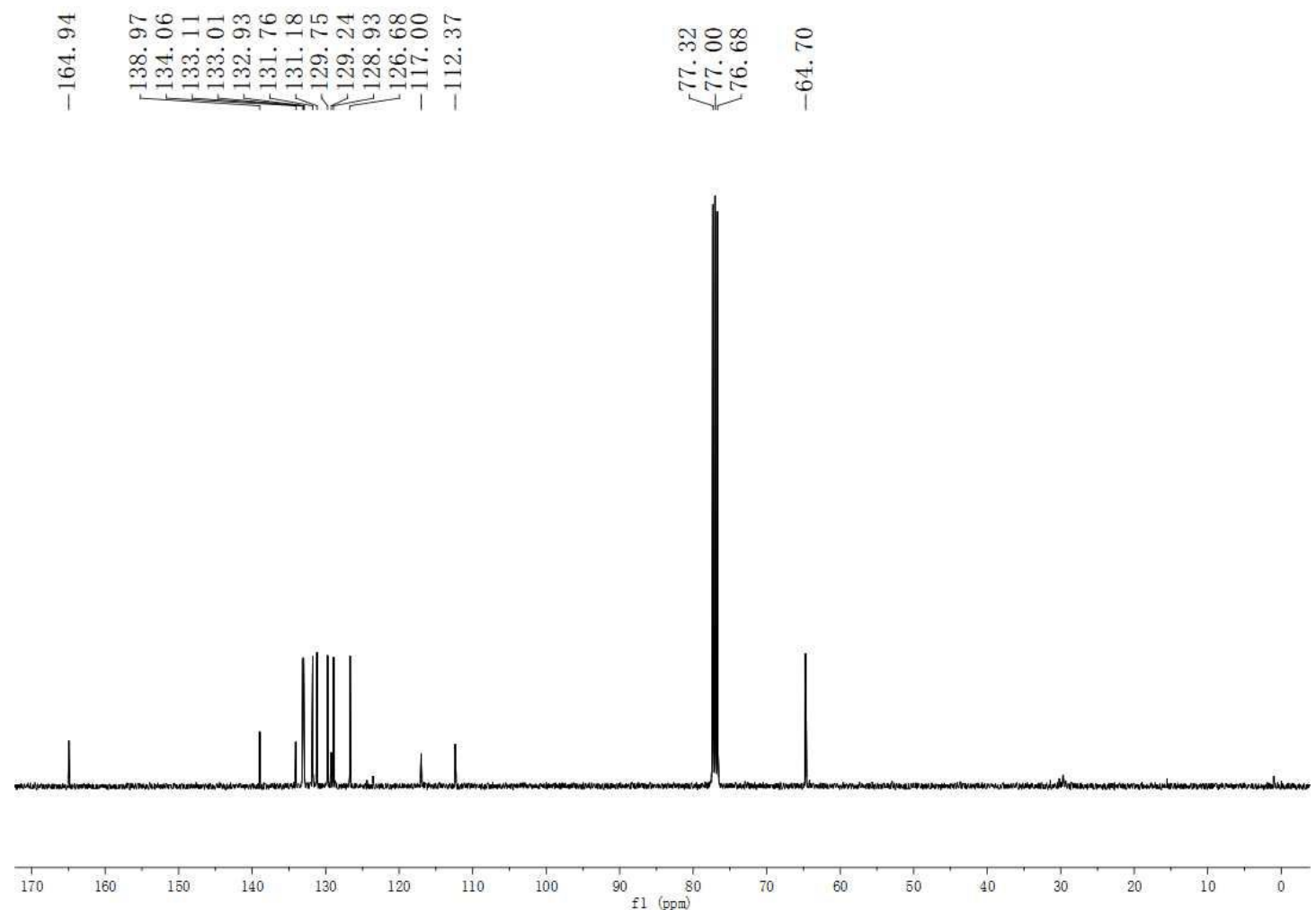

Figure S92 $100 \mathrm{MHz}{ }^{13} \mathrm{C}\left\{{ }^{1} \mathrm{H}\right\}$ NMR spectrum of $\mathbf{4 i}$ in $\mathrm{CDCl}_{3}$. 


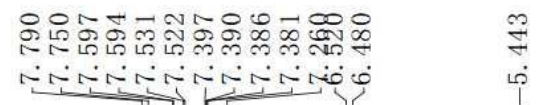<smiles>N#Cc1ccccc1COC(=O)/C=C/c1ccccc1</smiles>

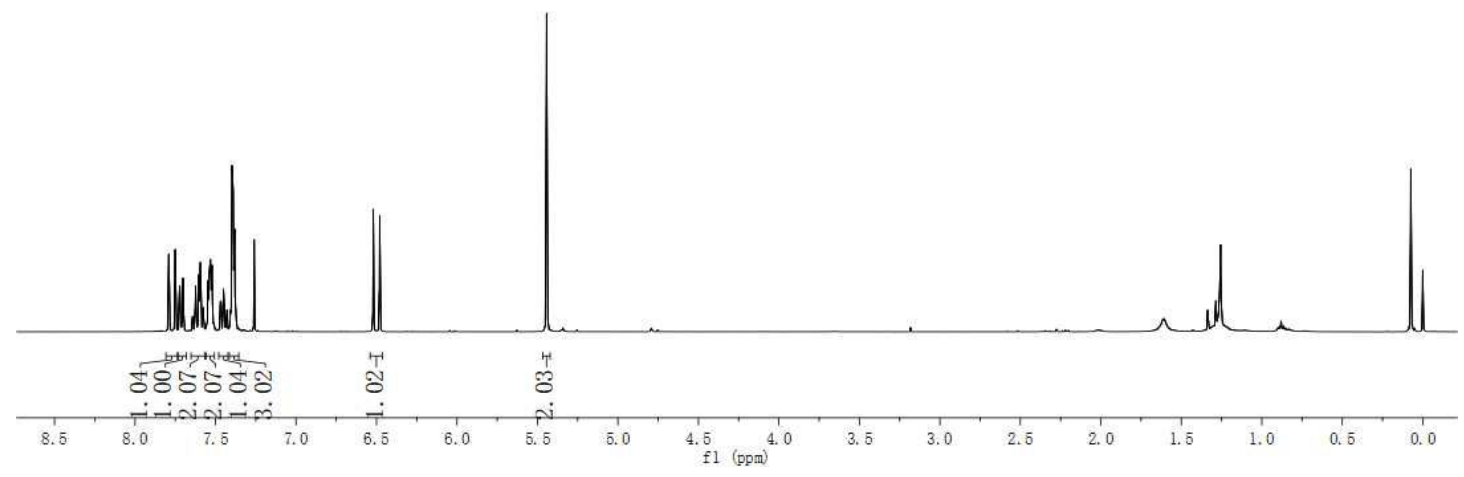

Figure S93. $400 \mathrm{MHz}{ }^{1} \mathrm{H} \mathrm{NMR}$ spectrum of $\mathbf{4 j}$ in $\mathrm{CDCl}_{3}$.

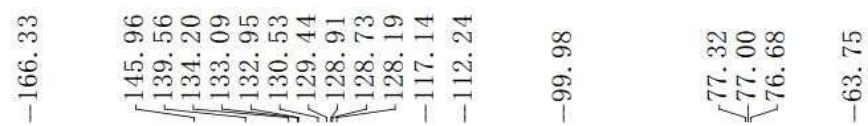
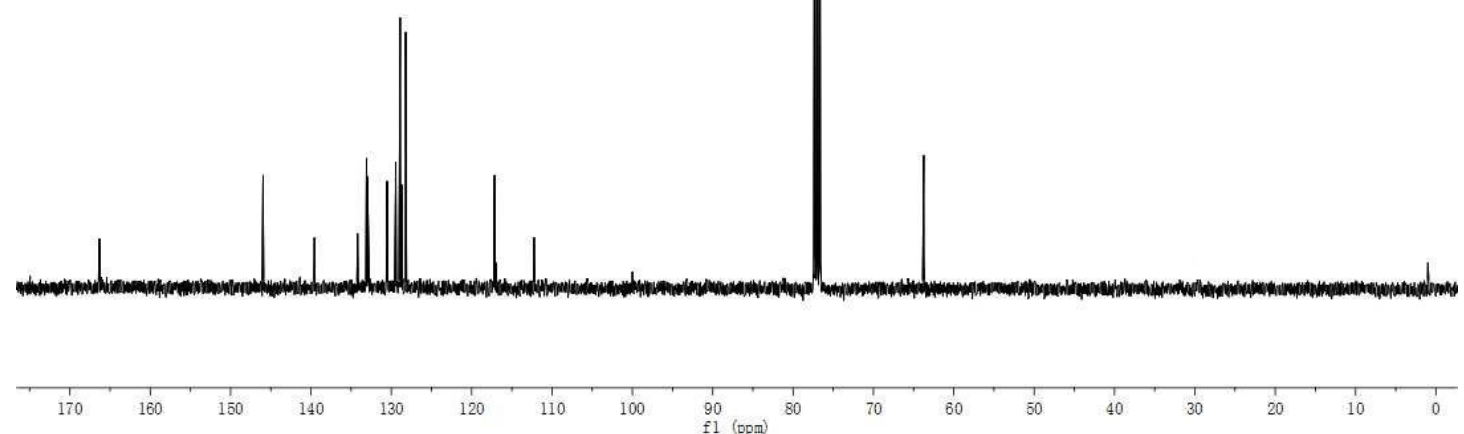

Figure $\mathbf{S 9 4} 100 \mathrm{MHz}{ }^{13} \mathrm{C}\left\{{ }^{1} \mathrm{H}\right\}$ NMR spectrum of $\mathbf{4 j}$ in $\mathrm{CDCl}_{3}$. 


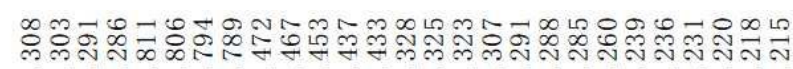

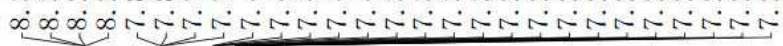
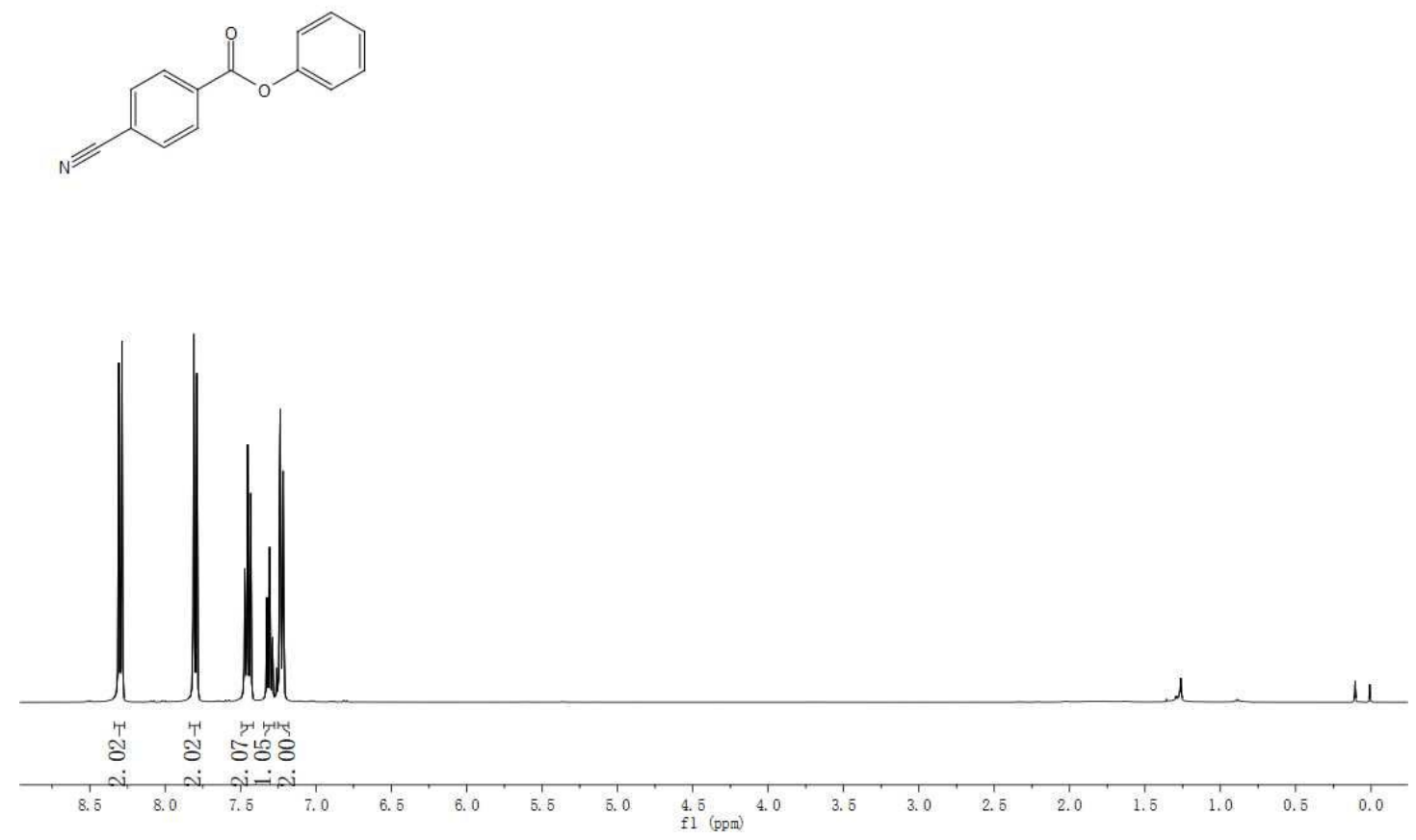

Figure S95. $400 \mathrm{MHz}{ }^{1} \mathrm{H}$ NMR spectrum of $\mathbf{4 k}$ in $\mathrm{CDCl}_{3}$.

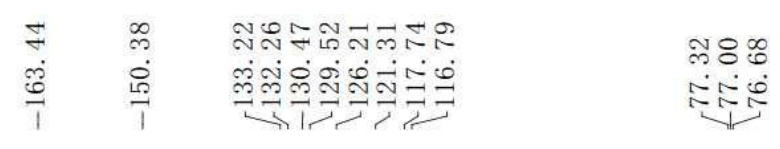
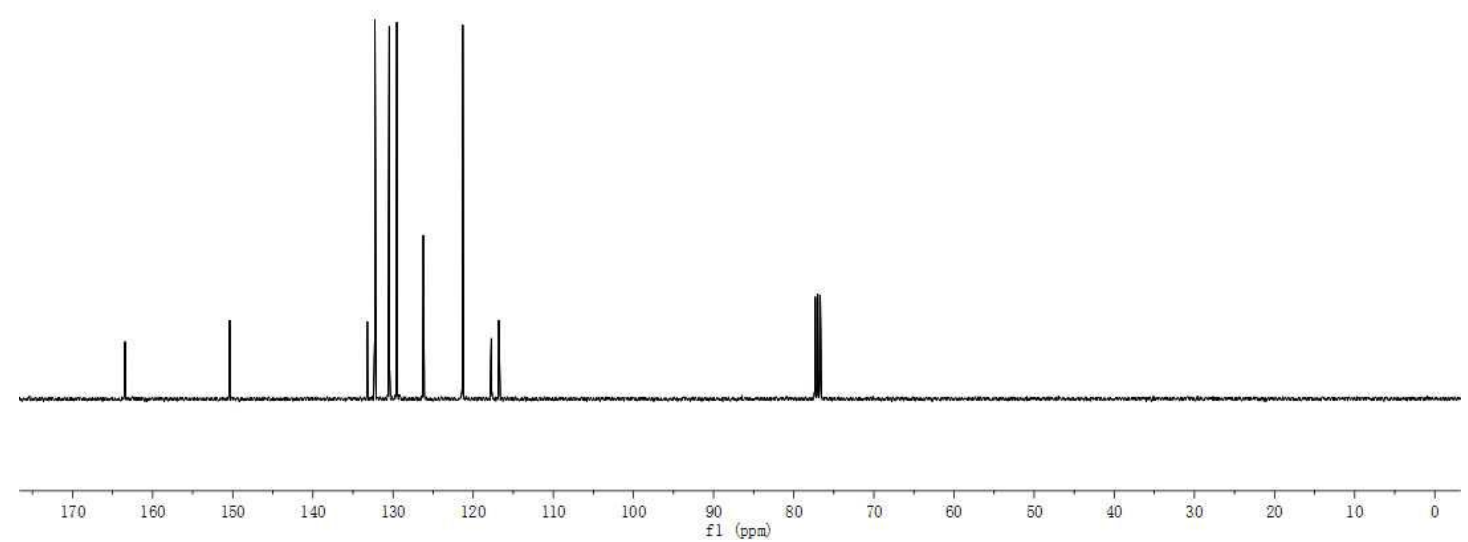

Figure $\mathbf{S 9 6} 100 \mathrm{MHz}{ }^{13} \mathrm{C}\left\{{ }^{1} \mathrm{H}\right\} \mathrm{NMR}$ spectrum of $\mathbf{4 k}$ in $\mathrm{CDCl}_{3}$. 


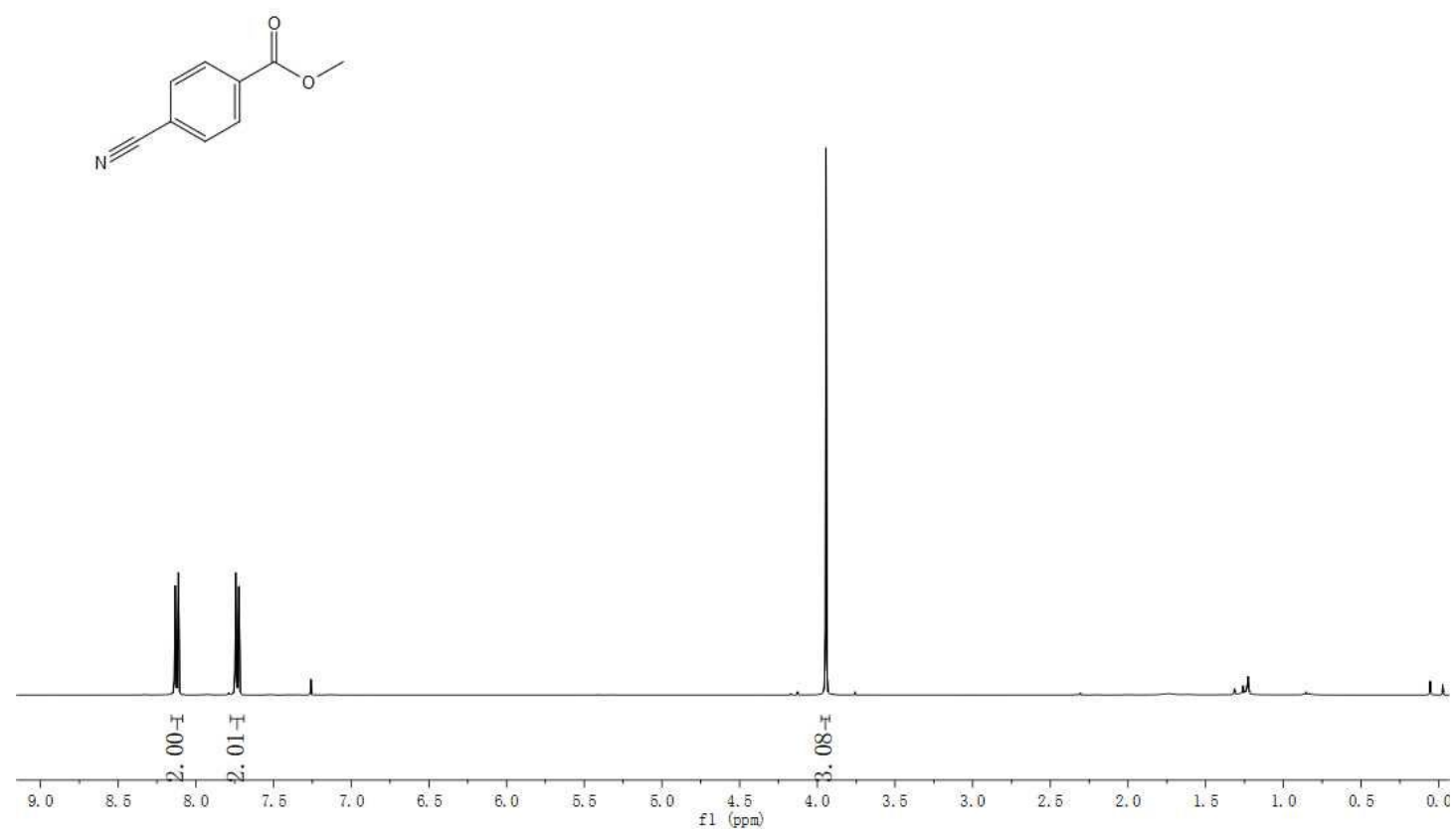

Figure S97. $400 \mathrm{MHz}{ }^{1} \mathrm{H}$ NMR spectrum of $4 \mathbf{l}$ in $\mathrm{CDCl}_{3}$.

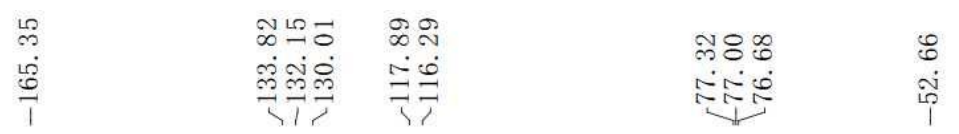

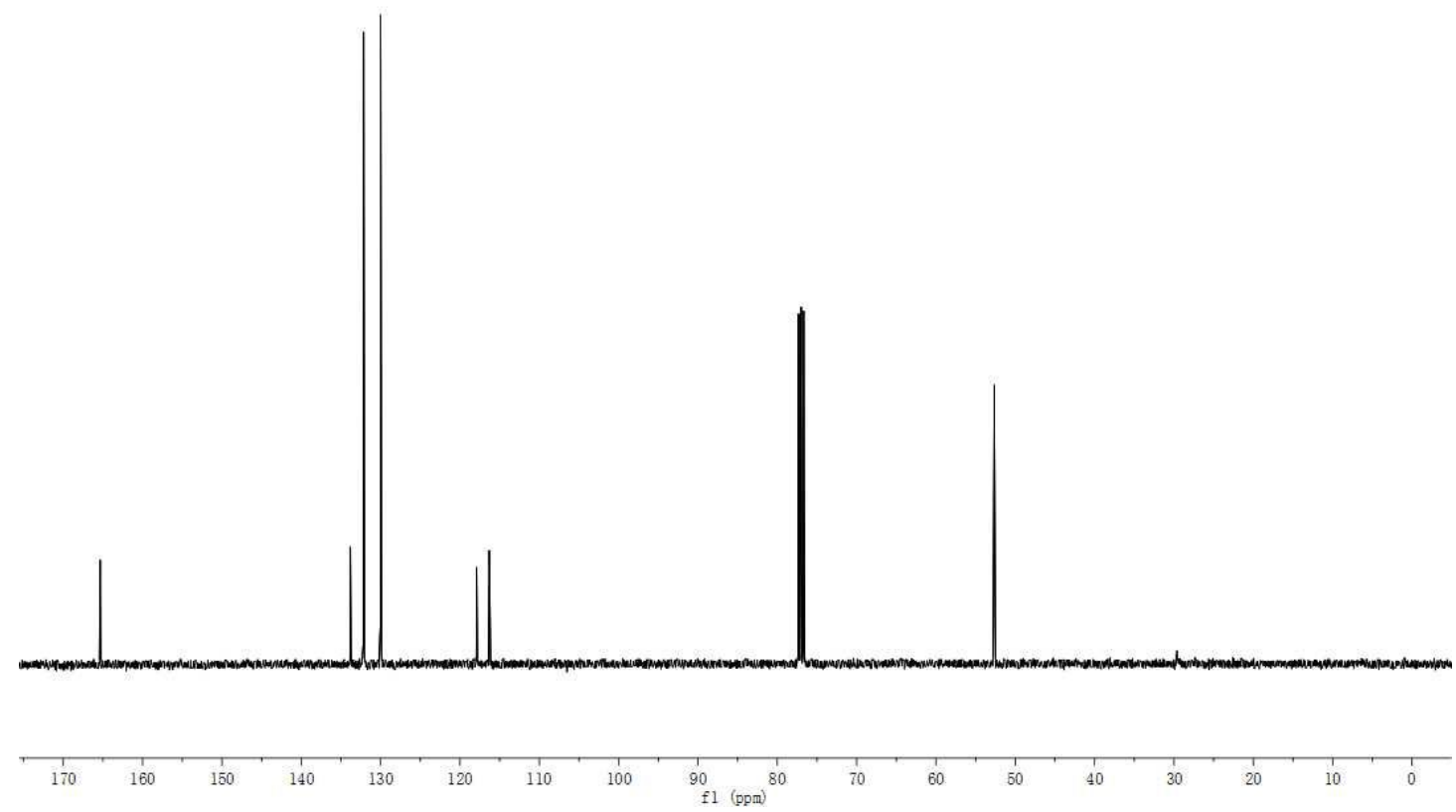

Figure S98 $100 \mathrm{MHz}{ }^{13} \mathrm{C}\left\{{ }^{1} \mathrm{H}\right\}$ NMR spectrum of $4 \mathbf{l}$ in $\mathrm{CDCl}_{3}$. 

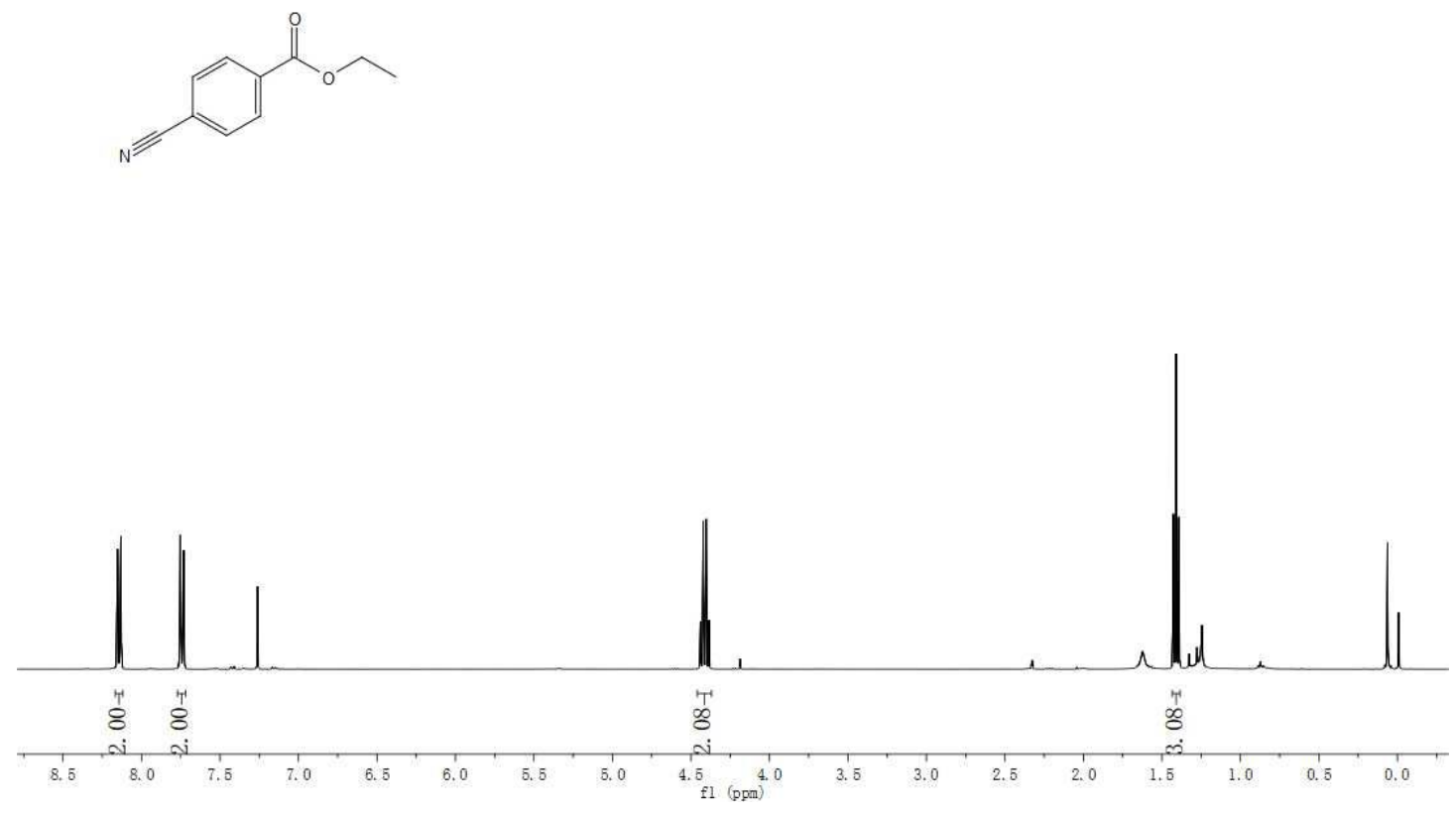

Figure S99. $400 \mathrm{MHz}{ }^{1} \mathrm{H}$ NMR spectrum of $\mathbf{4 m}$ in $\mathrm{CDCl}_{3}$.

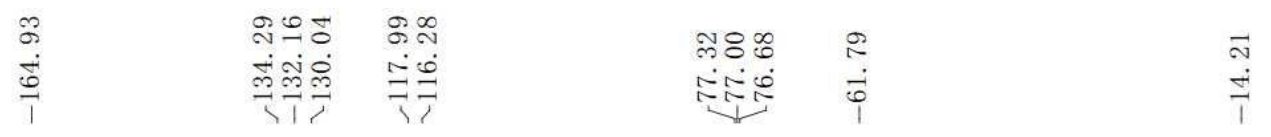
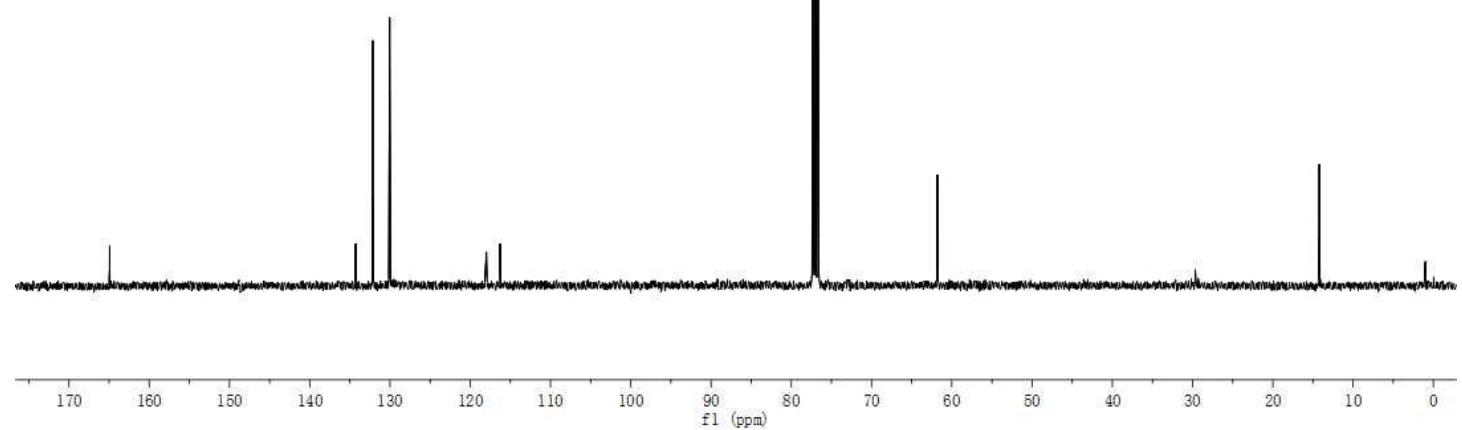

Figure $\mathbf{S 1 0 0} 100 \mathrm{MHz}{ }^{13} \mathrm{C}\left\{{ }^{1} \mathrm{H}\right\}$ NMR spectrum of $\mathbf{4 m}$ in $\mathrm{CDCl}_{3}$. 


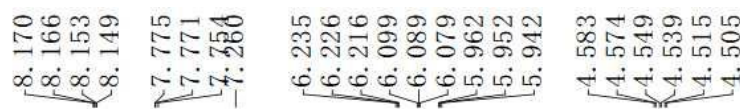<smiles>N#Cc1ccc(C(=O)OCC(F)F)cc1</smiles>

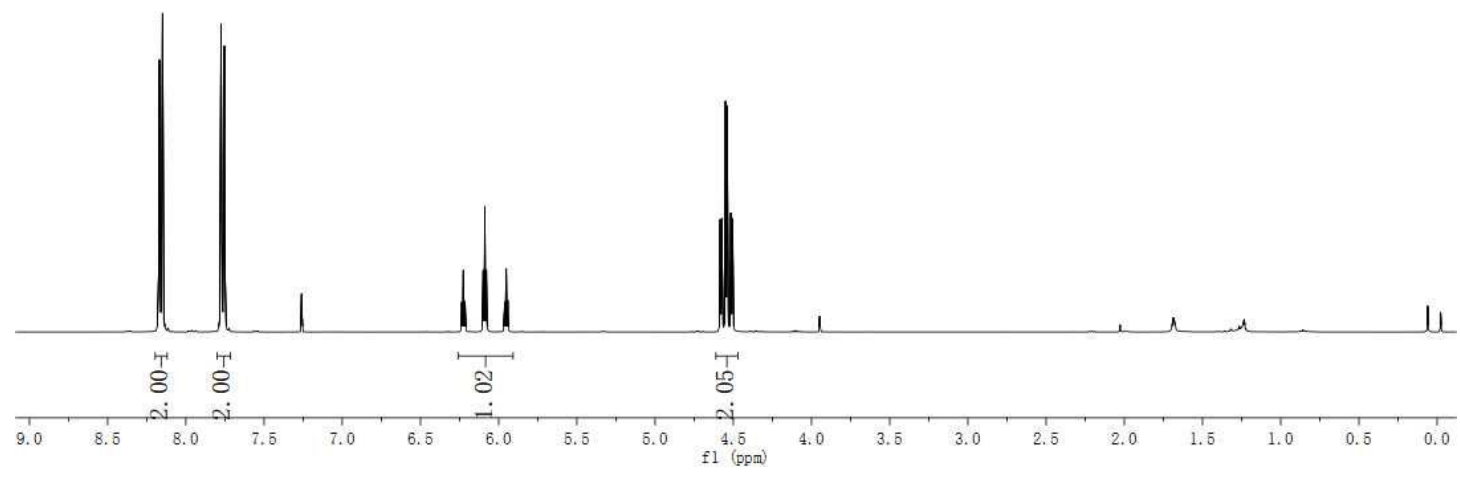

Figure S101. $400 \mathrm{MHz}{ }^{1} \mathrm{H}$ NMR spectrum of $\mathbf{4 n}$ in $\mathrm{CDCl}_{3}$.

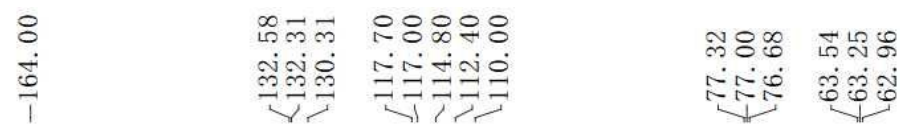
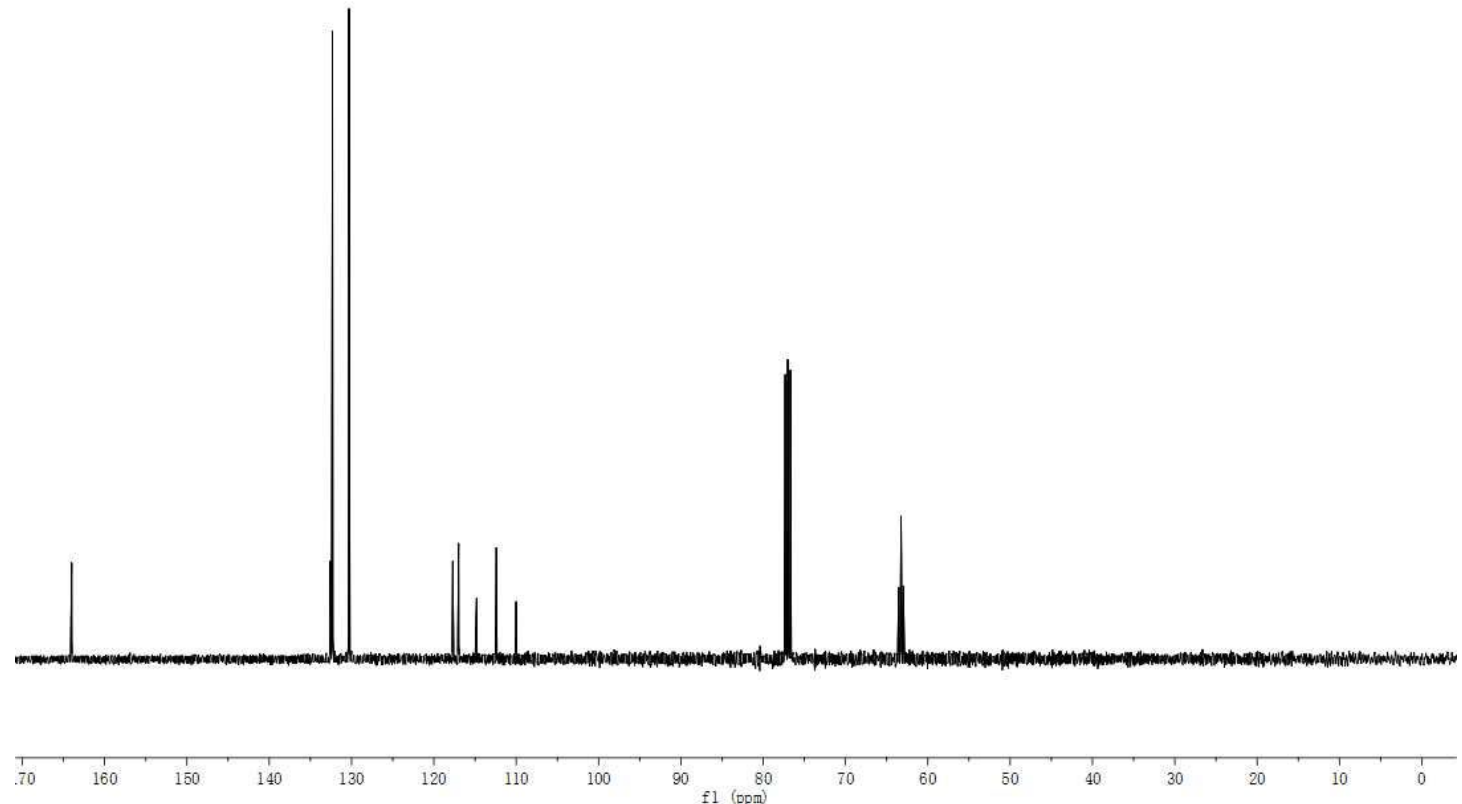

Figure $\mathbf{S 1 0 2} 100 \mathrm{MHz}{ }^{13} \mathrm{C}\left\{{ }^{1} \mathrm{H}\right\}$ NMR spectrum of $\mathbf{4 n}$ in $\mathrm{CDCl}_{3}$. 


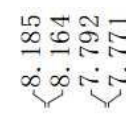

윤유:

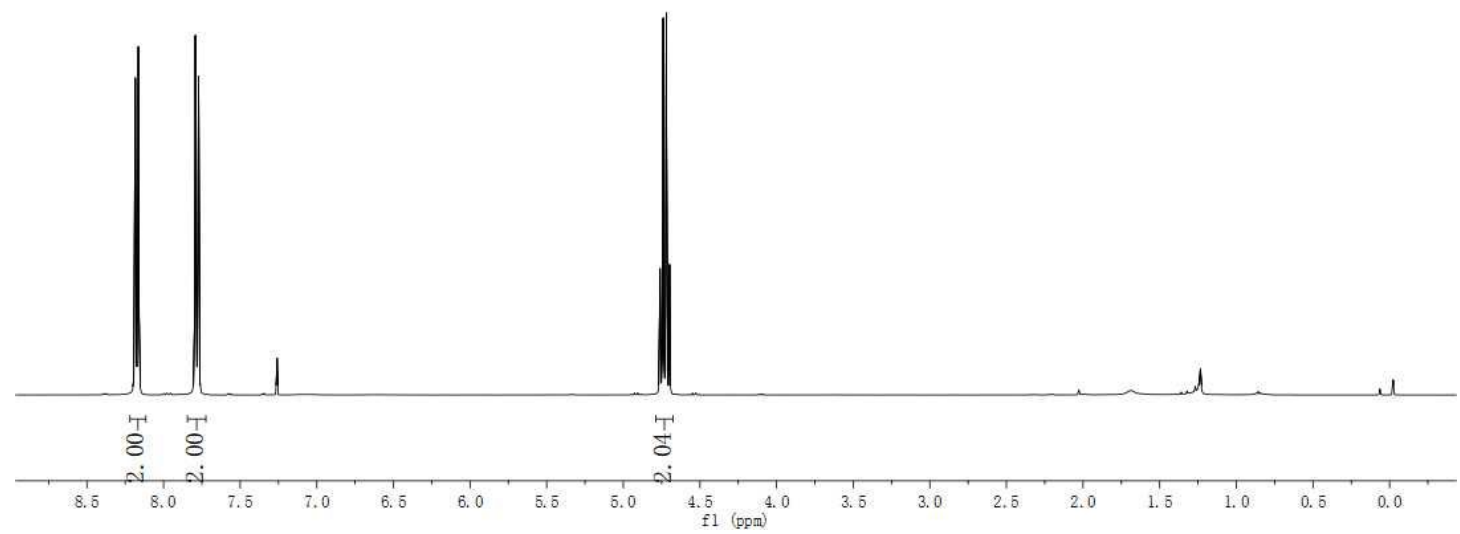

Figure S103. $400 \mathrm{MHz}{ }^{1} \mathrm{H}$ NMR spectrum of 40 in $\mathrm{CDCl}_{3}$.

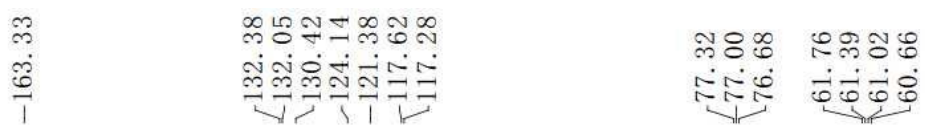
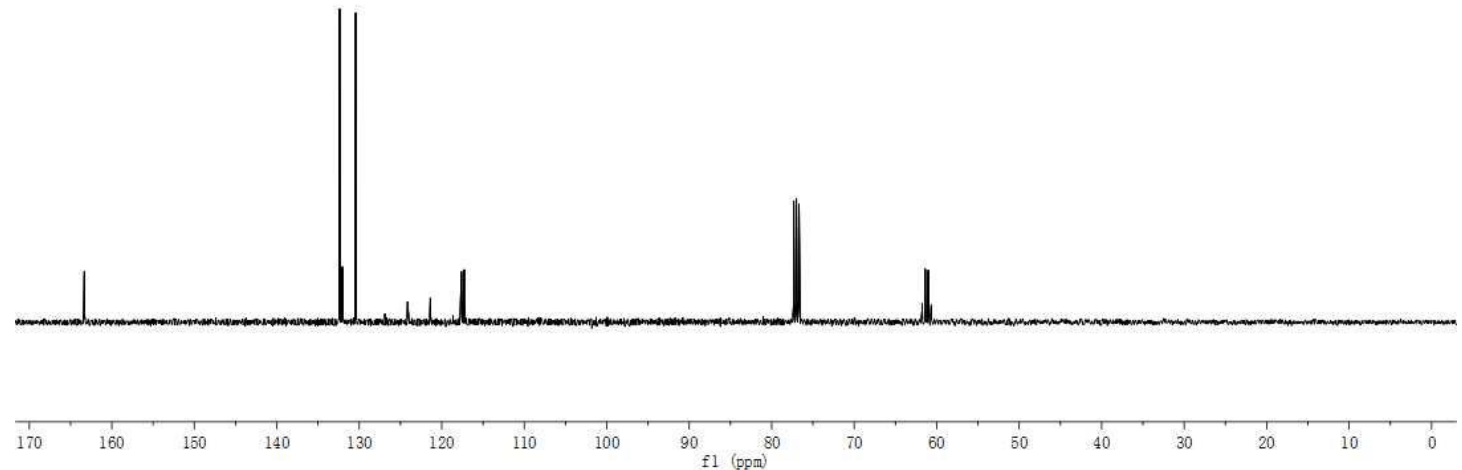

Figure $\mathbf{S 1 0 4} 100 \mathrm{MHz}{ }^{13} \mathrm{C}\left\{{ }^{1} \mathrm{H}\right\}$ NMR spectrum of 40 in $\mathrm{CDCl}_{3}$. 


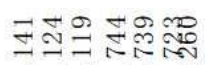

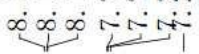

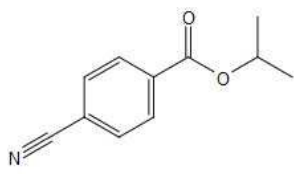

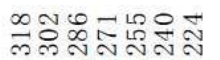

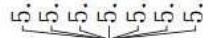

ప్ఠ

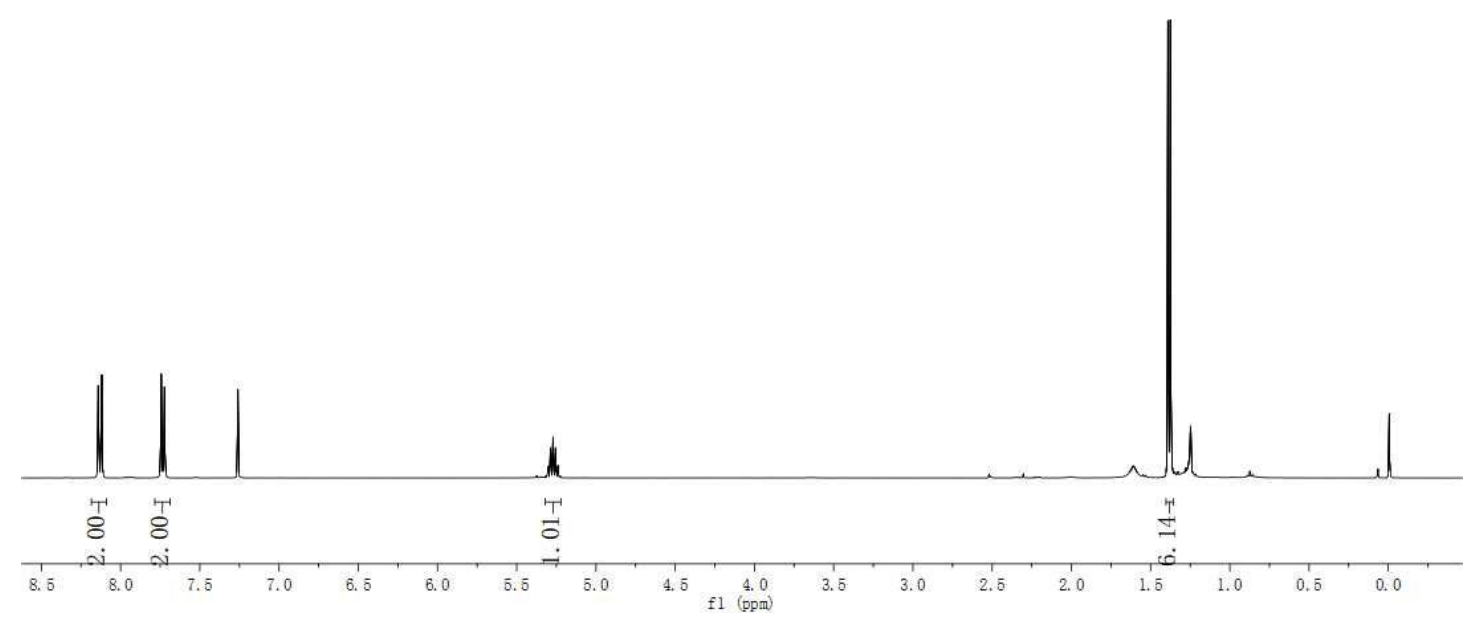

Figure S105. $400 \mathrm{MHz}{ }^{1} \mathrm{H}$ NMR spectrum of $\mathbf{4 p}$ in $\mathrm{CDCl}_{3}$.

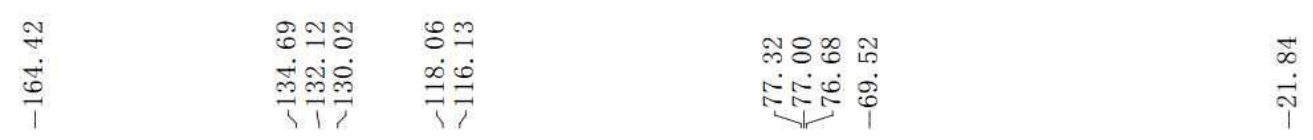

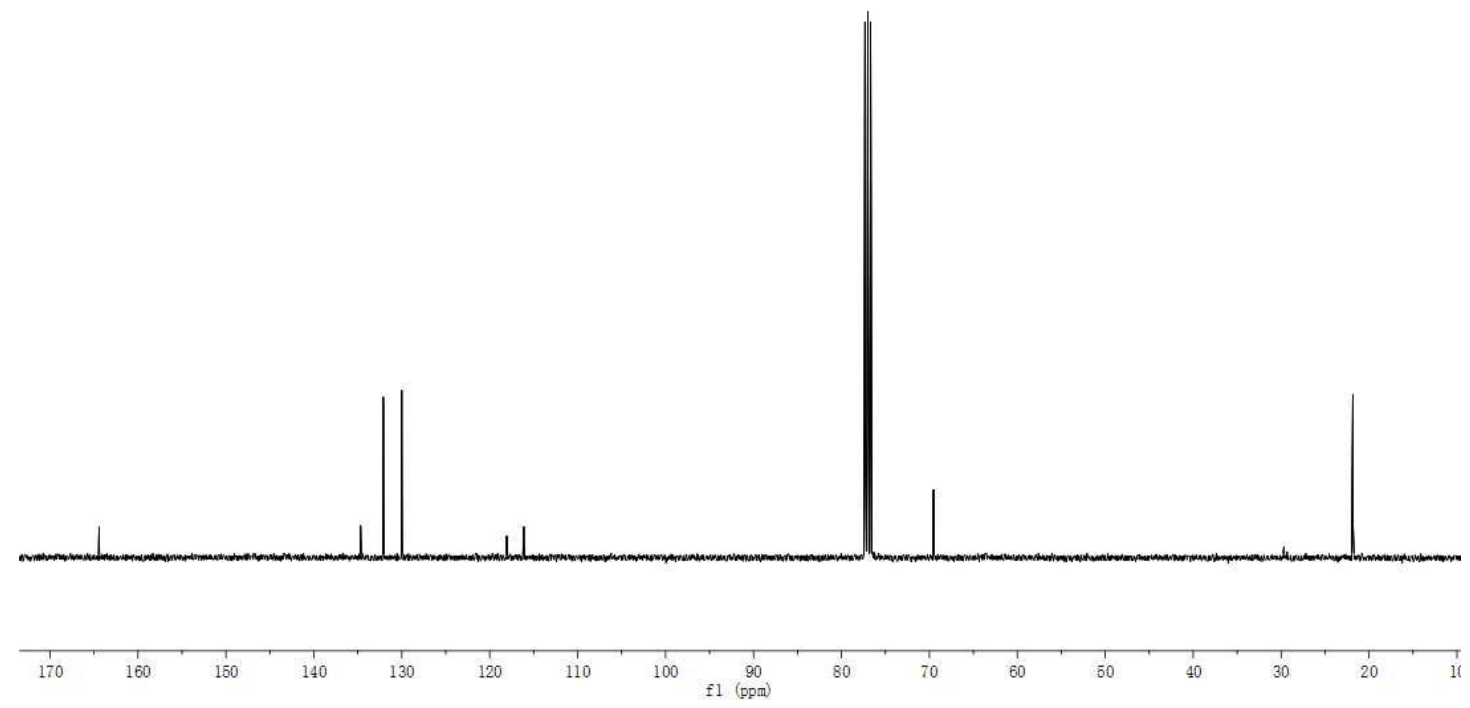

Figure $\mathbf{S 1 0 6} 100 \mathrm{MHz}{ }^{13} \mathrm{C}\left\{{ }^{1} \mathrm{H}\right\}$ NMR spectrum of $\mathbf{4 p}$ in $\mathrm{CDCl}_{3}$. 

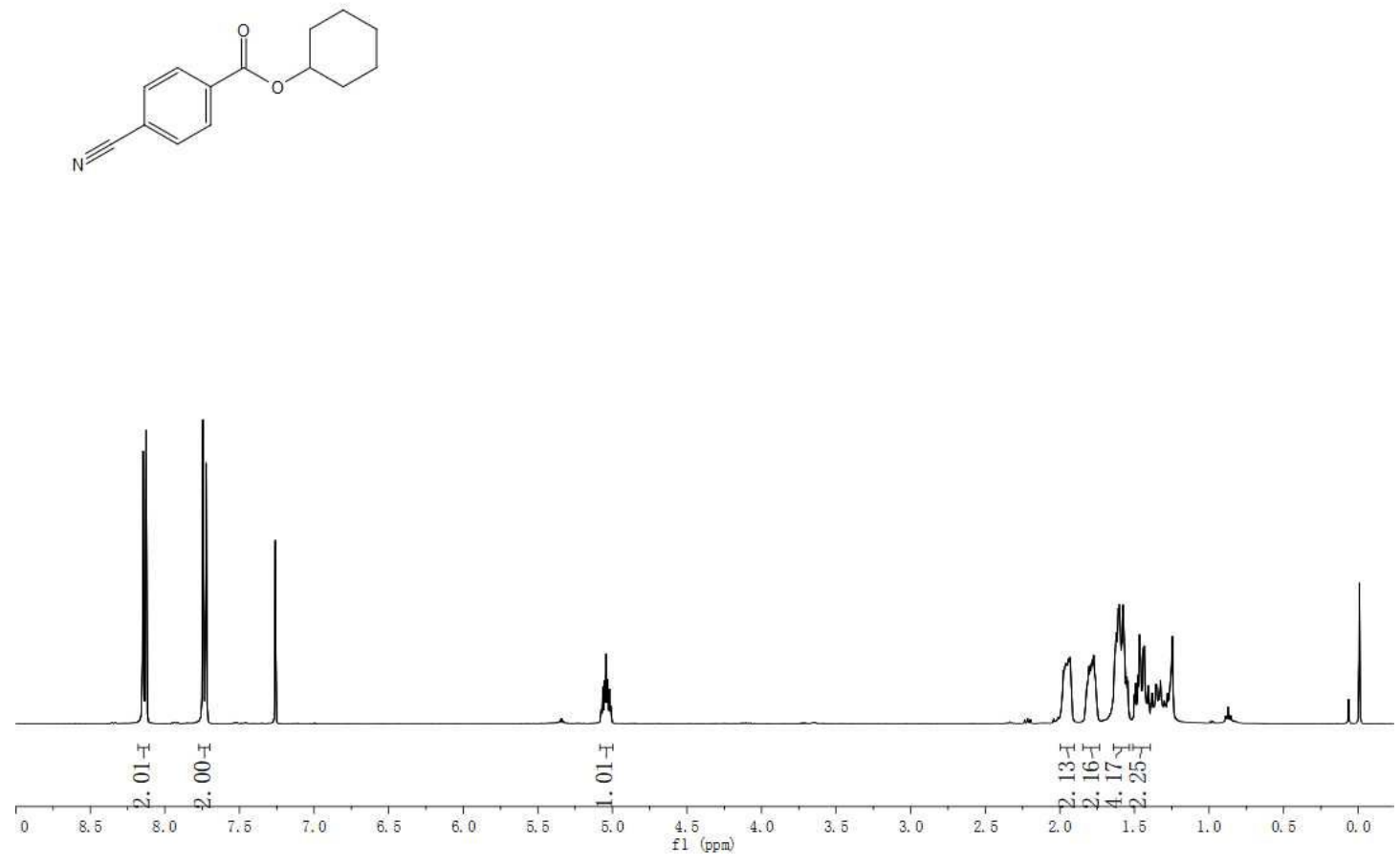

Figure S107. $400 \mathrm{MHz}{ }^{1} \mathrm{H}$ NMR spectrum of $\mathbf{4 q}$ in $\mathrm{CDCl}_{3}$.

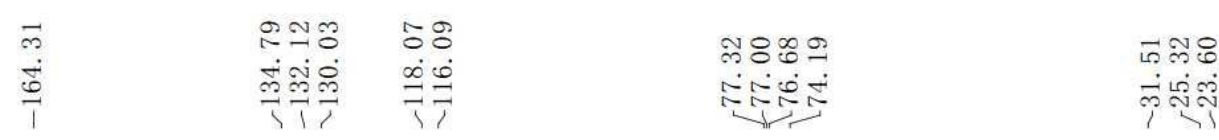

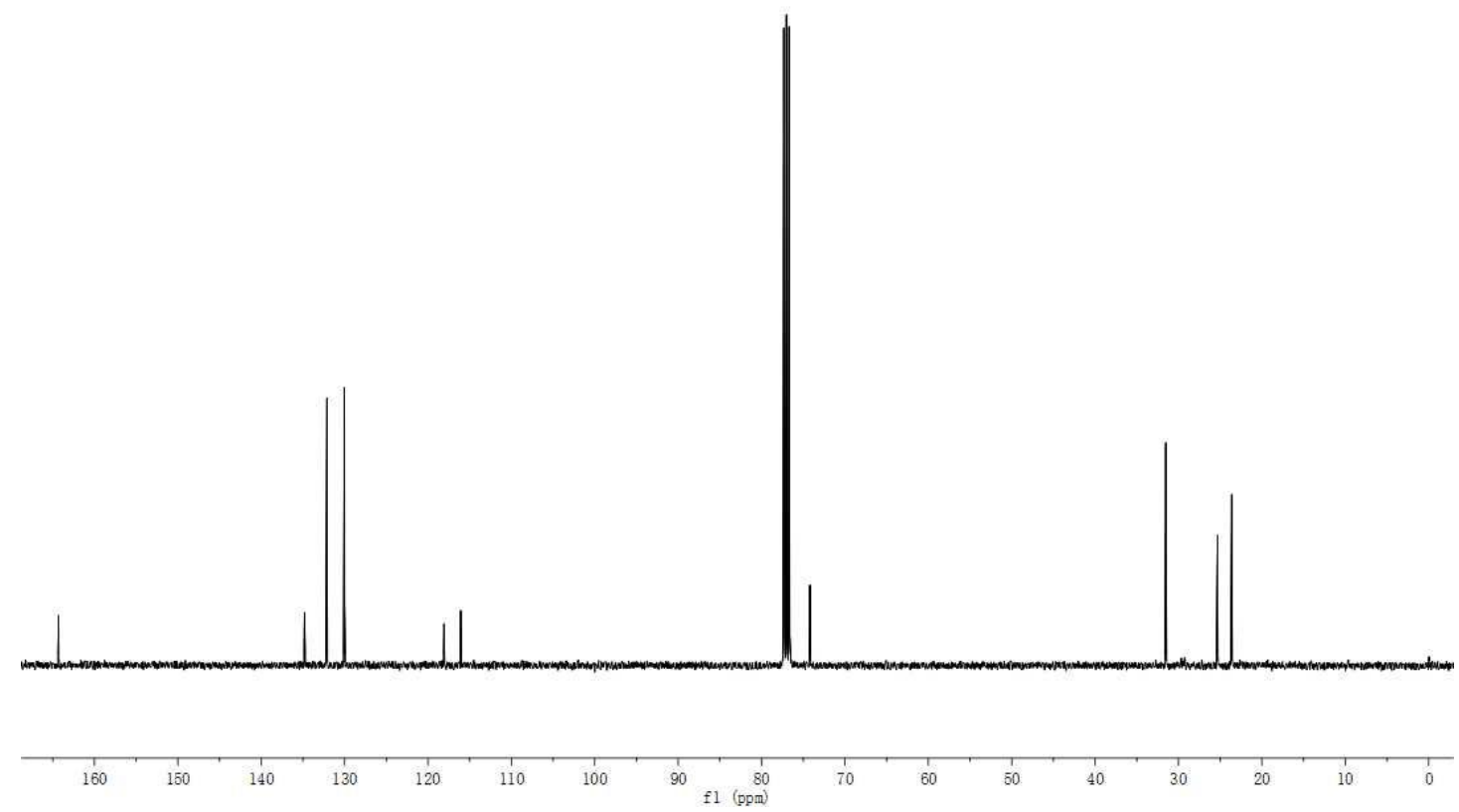

Figure $\mathbf{S 1 0 8} 100 \mathrm{MHz}{ }^{13} \mathrm{C}\left\{{ }^{1} \mathrm{H}\right\}$ NMR spectrum of $\mathbf{4 q}$ in $\mathrm{CDCl}_{3}$. 

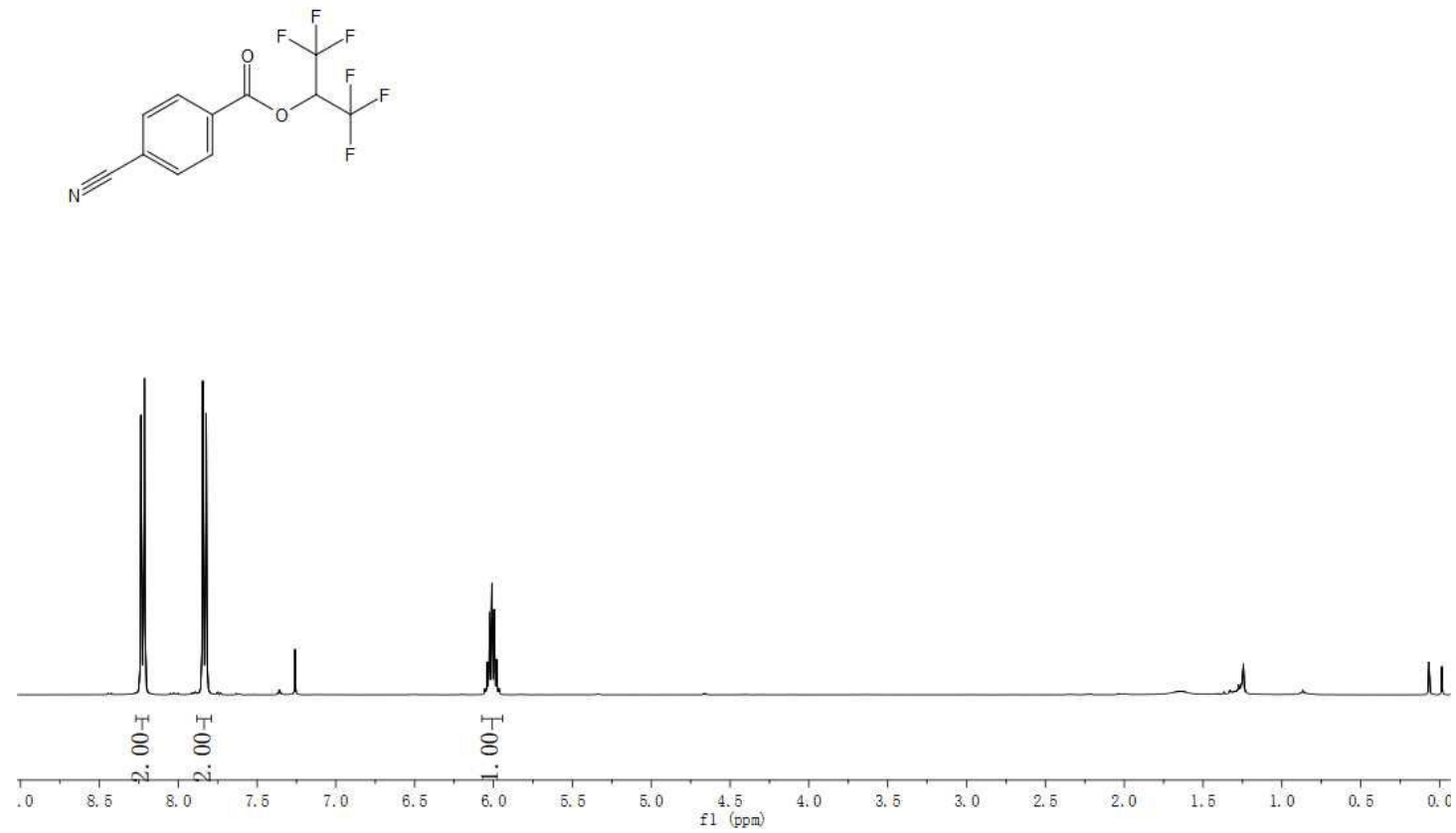

Figure S109. $400 \mathrm{MHz}{ }^{1} \mathrm{H}$ NMR spectrum of $4 \mathbf{r}$ in $\mathrm{CDCl}_{3}$.

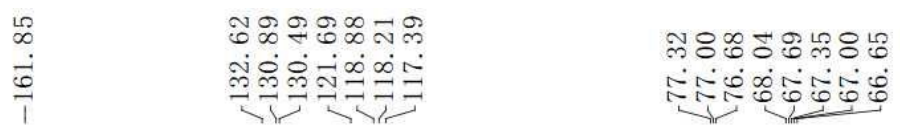
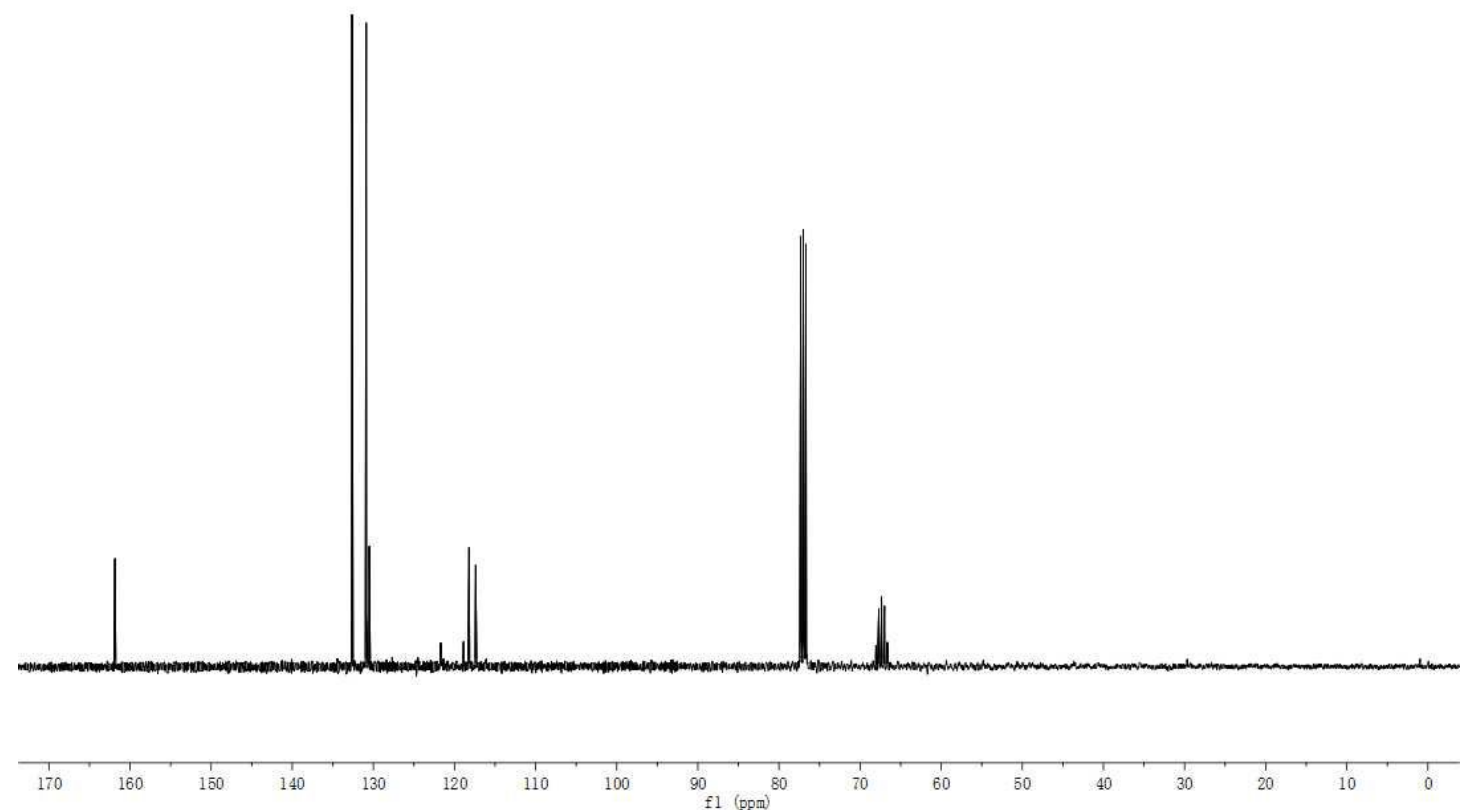

Figure $\mathbf{S 1 1 0} 100 \mathrm{MHz}{ }^{13} \mathrm{C}\left\{{ }^{1} \mathrm{H}\right\}$ NMR spectrum of $4 \mathbf{r}$ in $\mathrm{CDCl}_{3}$. 


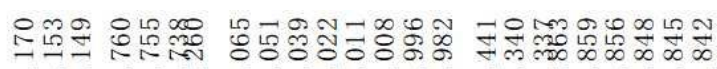

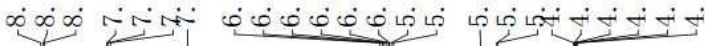
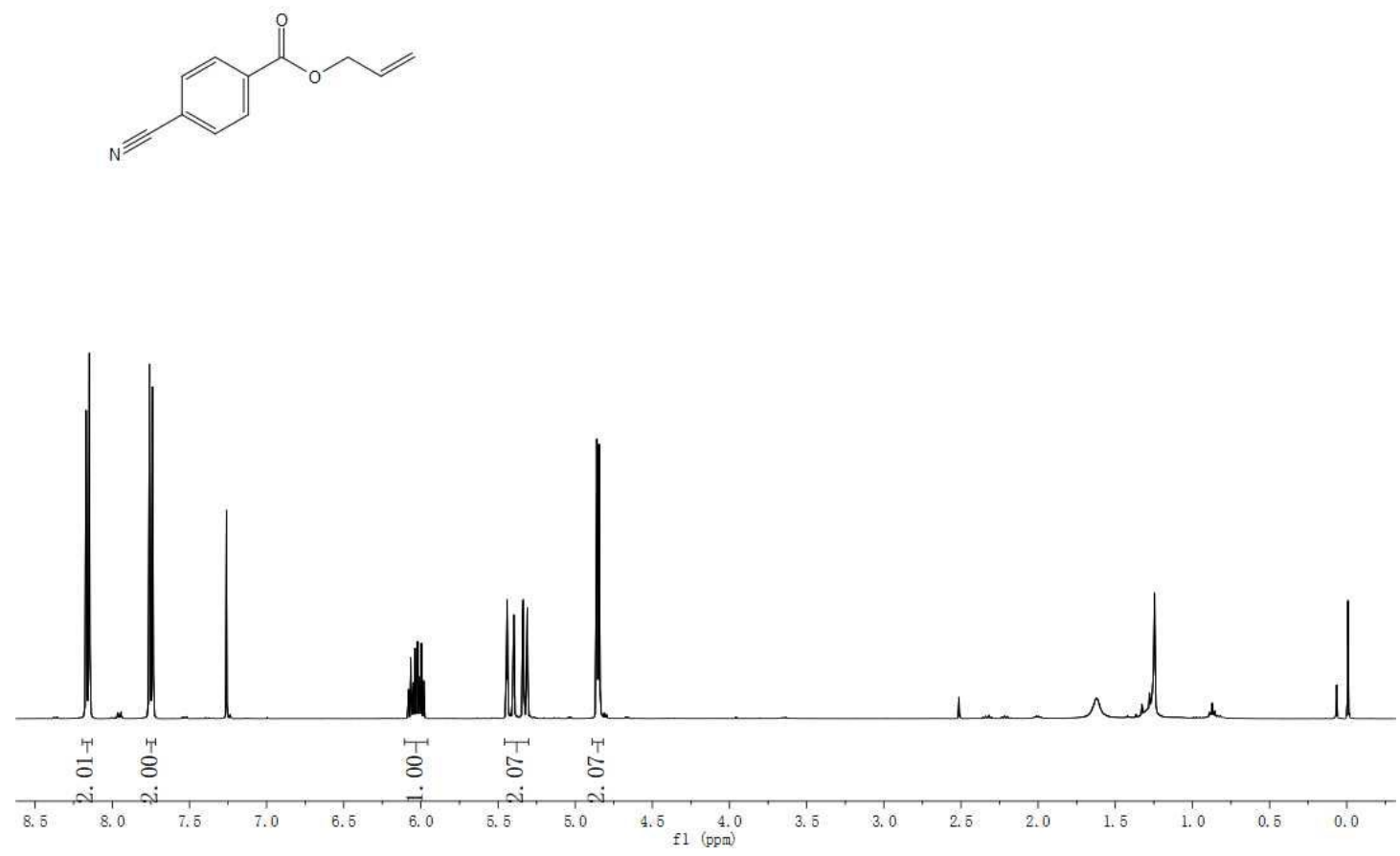

Figure S111. $400 \mathrm{MHz}{ }^{1} \mathrm{H}$ NMR spectrum of $4 \mathrm{~s}$ in $\mathrm{CDCl}_{3}$.

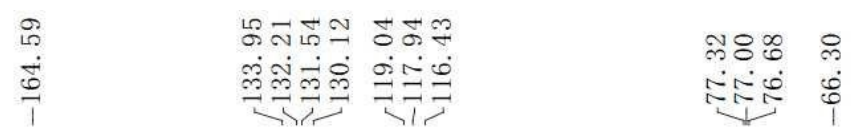
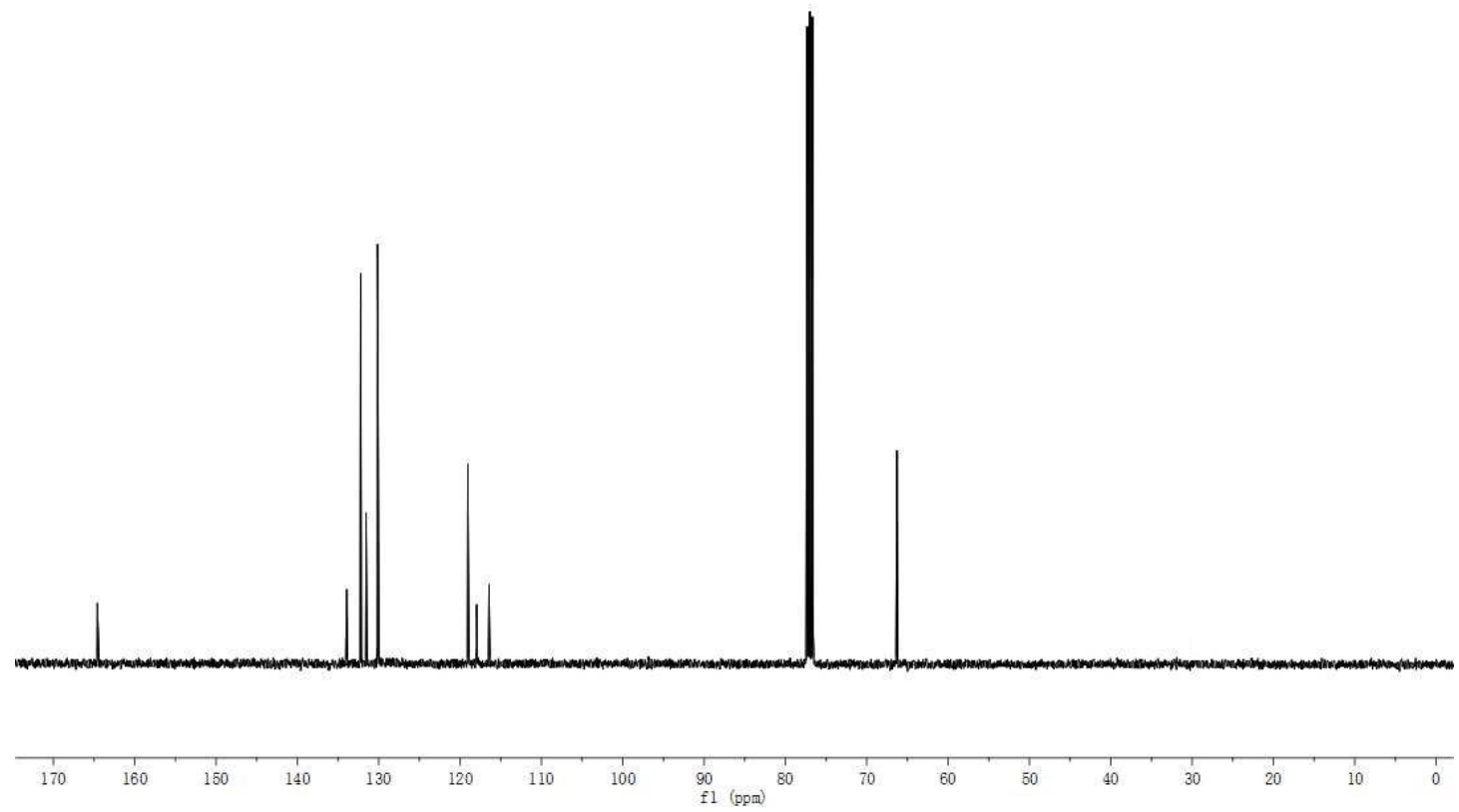

Figure S112 $100 \mathrm{MHz}{ }^{13} \mathrm{C}\left\{{ }^{1} \mathrm{H}\right\}$ NMR spectrum of $\mathbf{4 s}$ in $\mathrm{CDCl}_{3}$. 


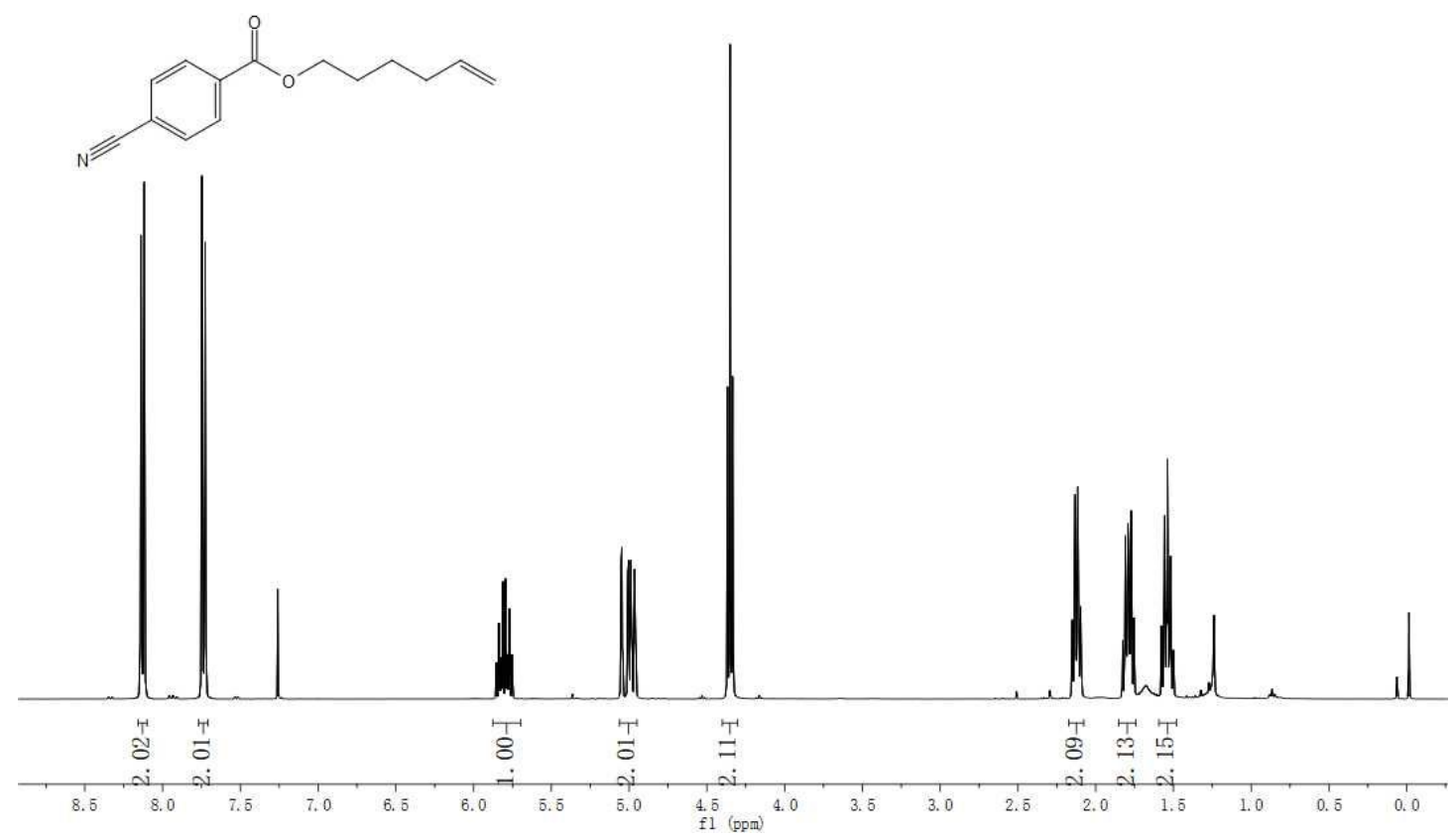

Figure S113. $400 \mathrm{MHz}{ }^{1} \mathrm{H}$ NMR spectrum of $4 \mathbf{t}$ in $\mathrm{CDCl}_{3}$.

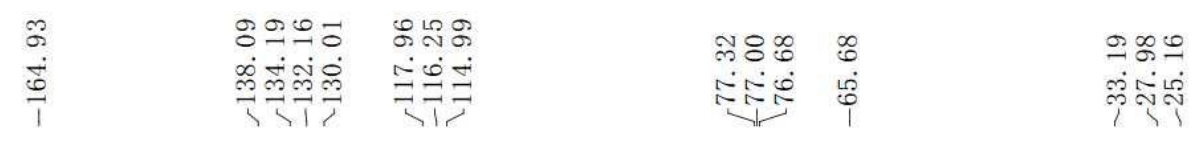
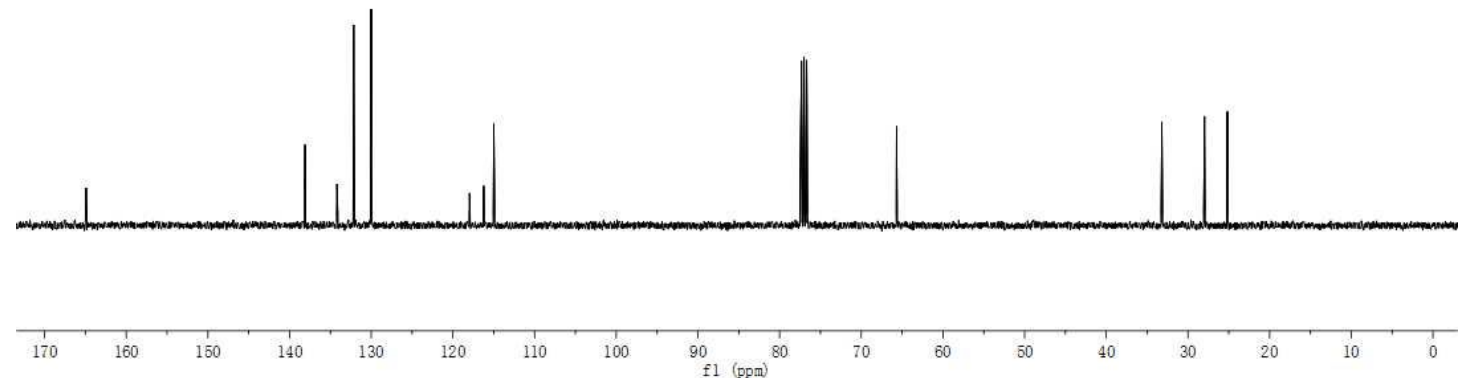

Figure S114 $100 \mathrm{MHz}{ }^{13} \mathrm{C}\left\{{ }^{1} \mathrm{H}\right\}$ NMR spectrum of $\mathbf{4 t}$ in $\mathrm{CDCl}_{3}$. 

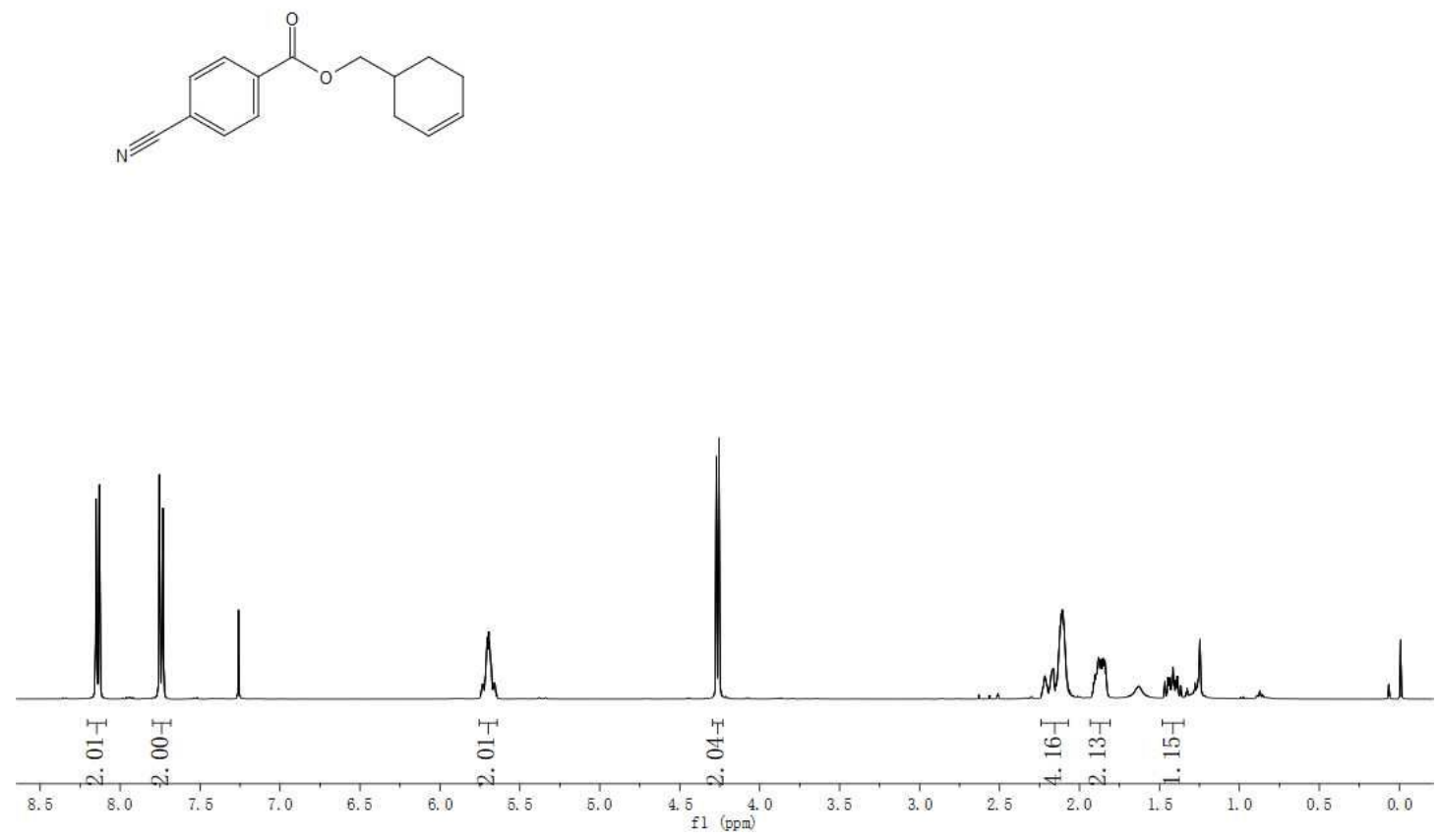

Figure $\mathbf{S 1 1 5 .} 400 \mathrm{MHz}{ }^{1} \mathrm{H}$ NMR spectrum of $\mathbf{4} \mathbf{u}$ in $\mathrm{CDCl}_{3}$.

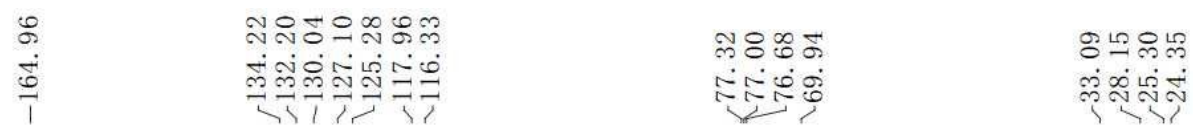
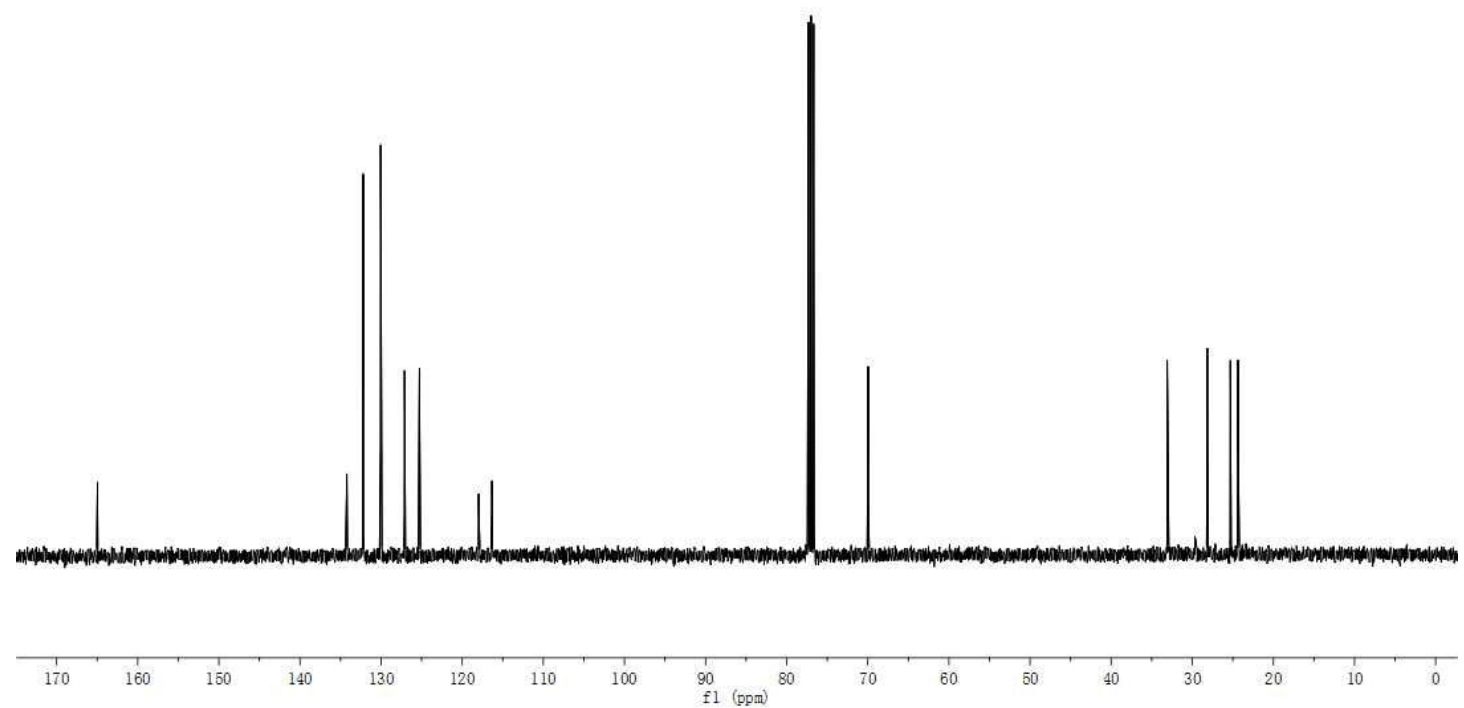

Figure $\mathbf{S 1 1 6} 100 \mathrm{MHz}{ }^{13} \mathrm{C}\left\{{ }^{1} \mathrm{H}\right\} \mathrm{NMR}$ spectrum of $\mathbf{4} \mathbf{u}$ in $\mathrm{CDCl}_{3}$. 


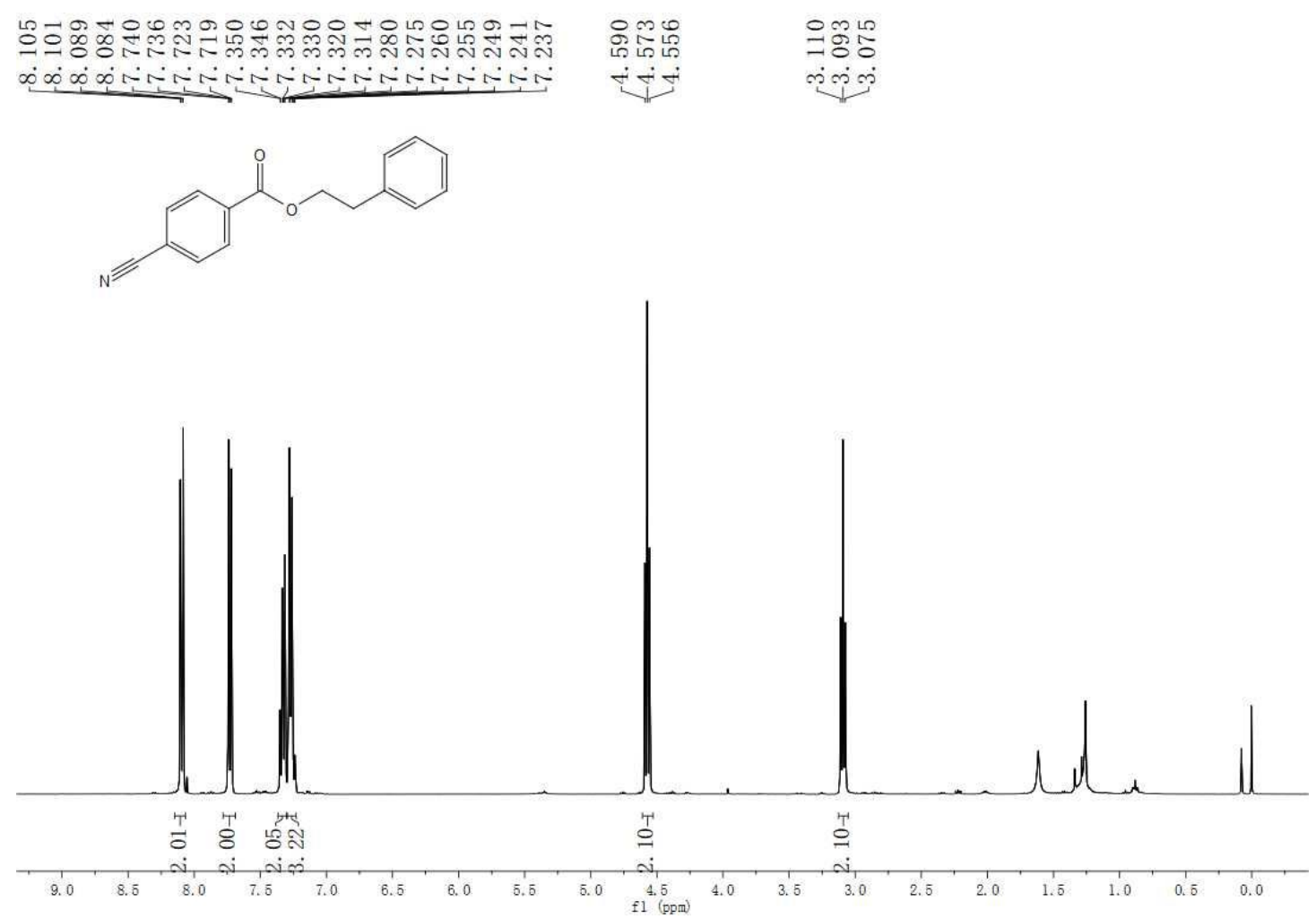

Figure S117. $400 \mathrm{MHz}{ }^{1} \mathrm{H}$ NMR spectrum of $\mathbf{4 v}$ in $\mathrm{CDCl}_{3}$.

\begin{tabular}{|c|c|c|}
\hline$\vec{\infty}$ & 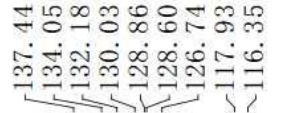 & 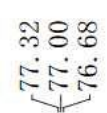 \\
\hline
\end{tabular}

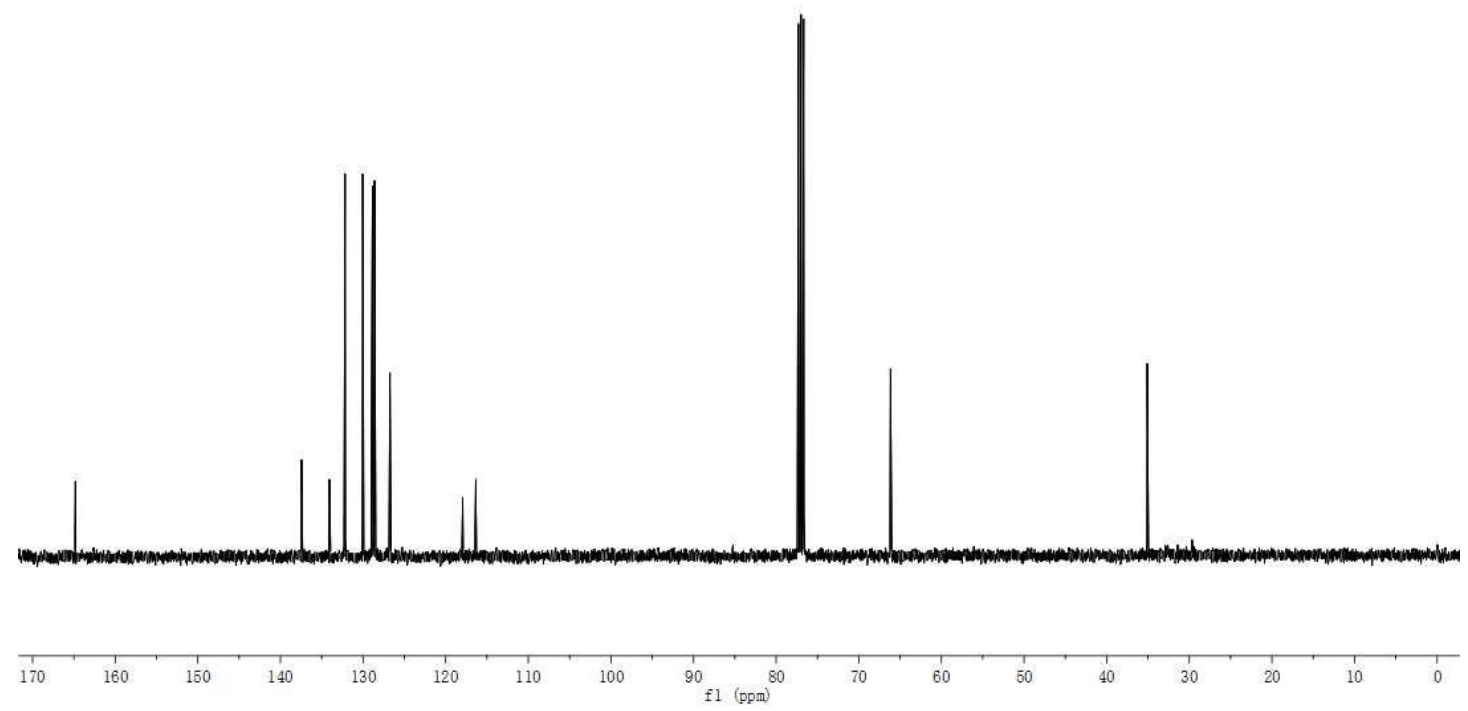

Figure $\mathbf{S 1 1 8} 100 \mathrm{MHz}{ }^{13} \mathrm{C}\left\{{ }^{1} \mathrm{H}\right\} \mathrm{NMR}$ spectrum of $\mathbf{4 v}$ in $\mathrm{CDCl}_{3}$. 


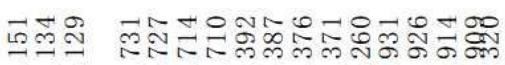

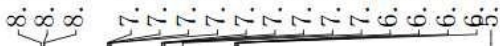
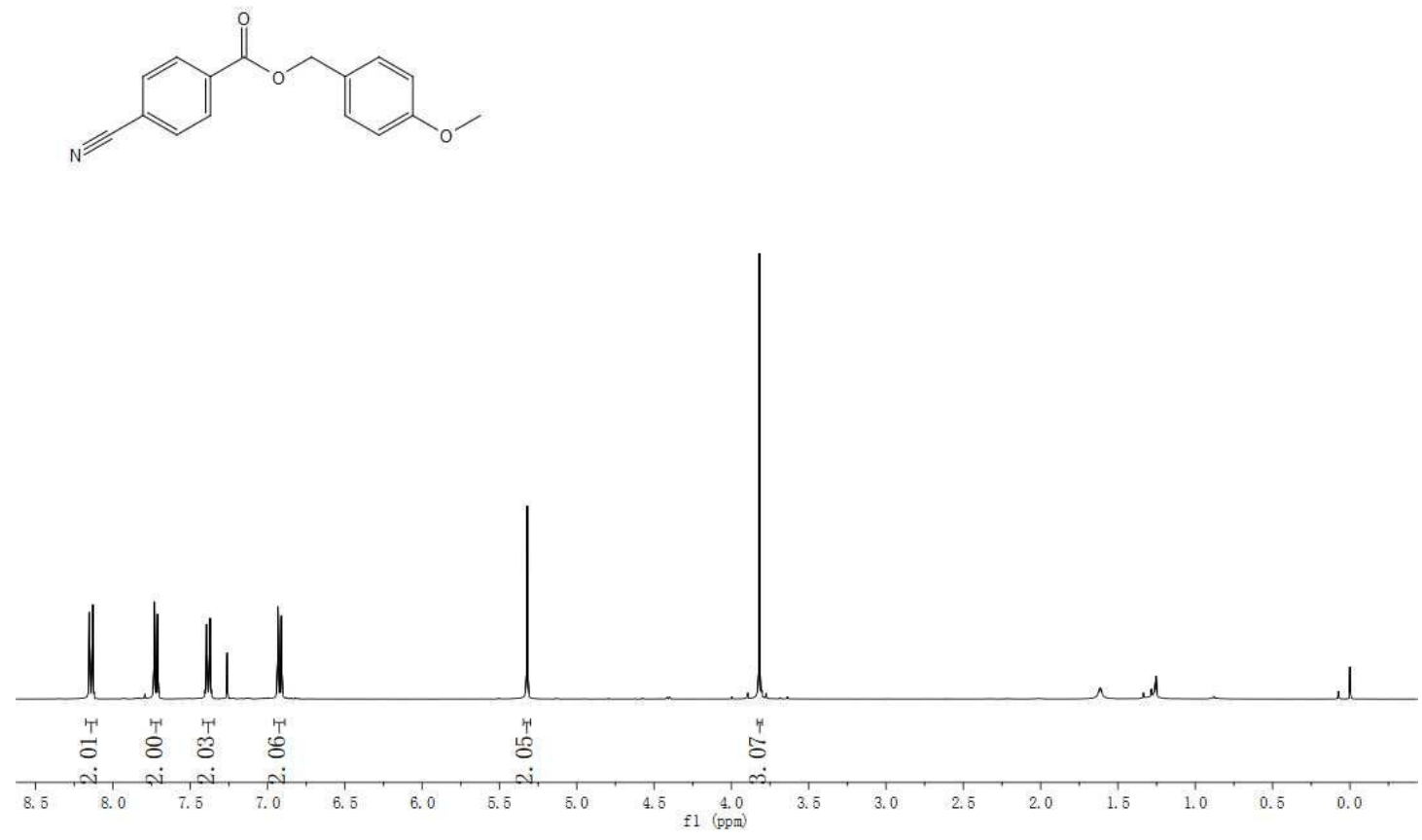

Figure S119. $400 \mathrm{MHz}{ }^{1} \mathrm{H}$ NMR spectrum of $4 \mathbf{w}$ in $\mathrm{CDCl}_{3}$.

辡部

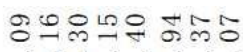

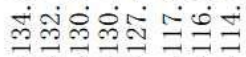

तै 80 ले शे

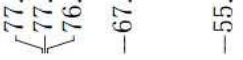

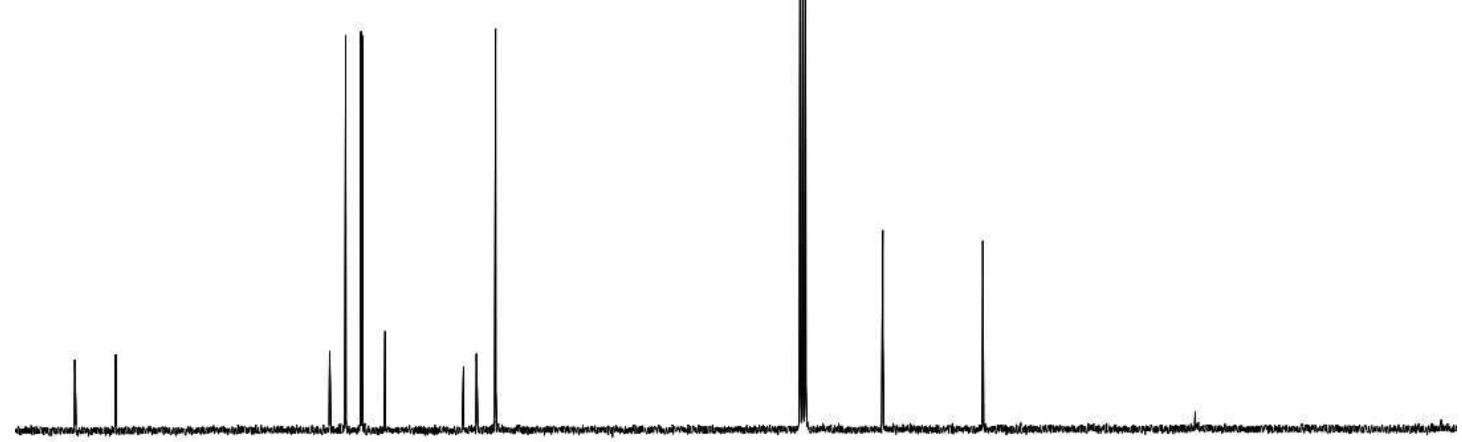

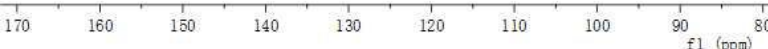

Figure $\mathbf{S 1 2 0} 100 \mathrm{MHz}{ }^{13} \mathrm{C}\left\{{ }^{1} \mathrm{H}\right\}$ NMR spectrum of $\mathbf{4} \mathbf{w}$ in $\mathrm{CDCl}_{3}$. 


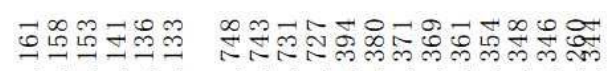

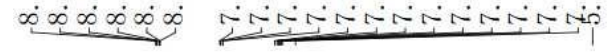
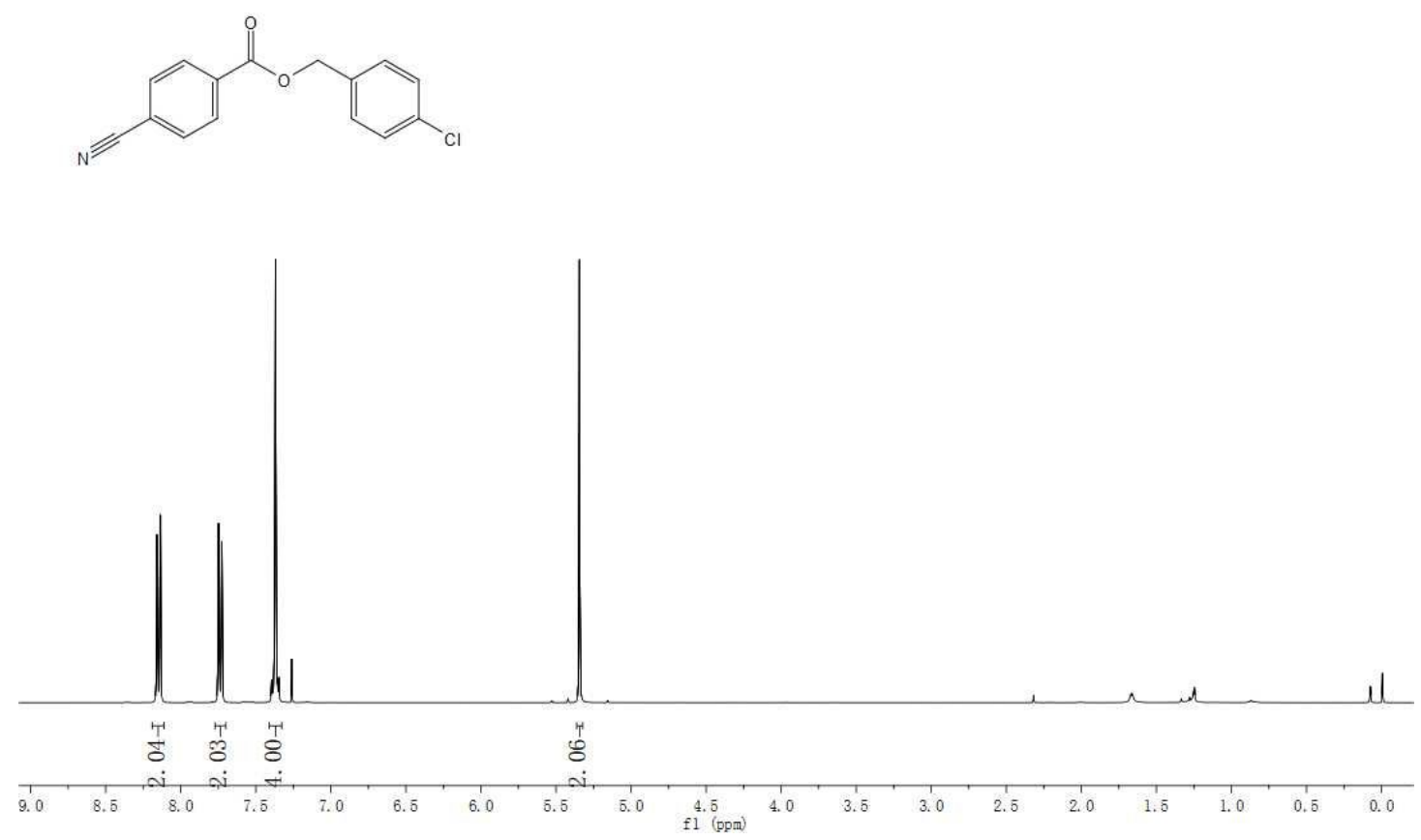

Figure S121. $400 \mathrm{MHz}{ }^{1} \mathrm{H}$ NMR spectrum of $\mathbf{4 x}$ in $\mathrm{CDCl}_{3}$.
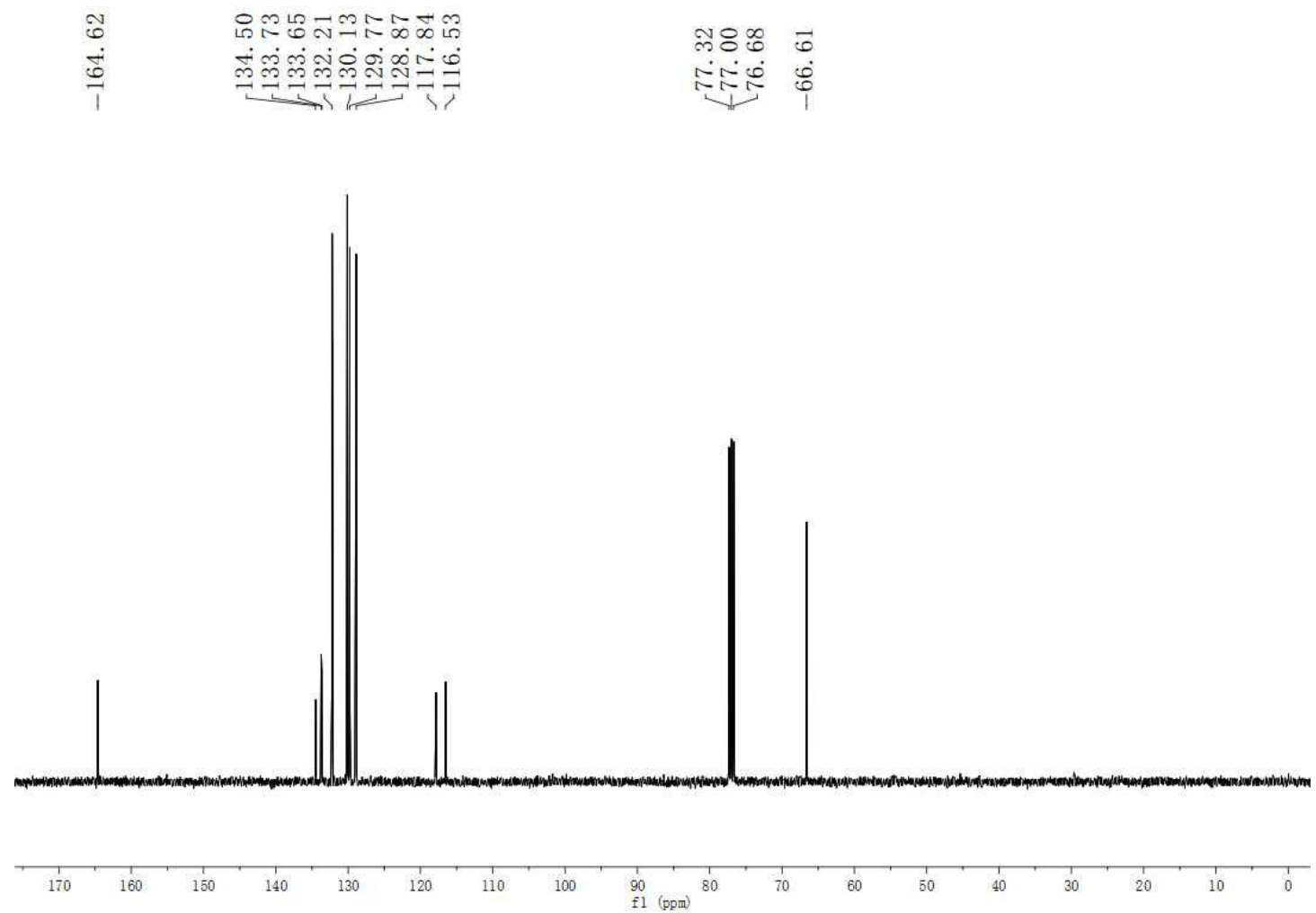

Figure $\mathbf{S 1 2 2} 100 \mathrm{MHz}{ }^{13} \mathrm{C}\left\{{ }^{1} \mathrm{H}\right\}$ NMR spectrum of $\mathbf{4 x}$ in $\mathrm{CDCl}_{3}$. 


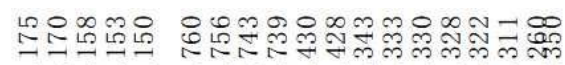

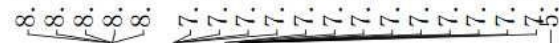<smiles>N#Cc1ccc(C(=O)OCc2cccc(Cl)c2)cc1</smiles>

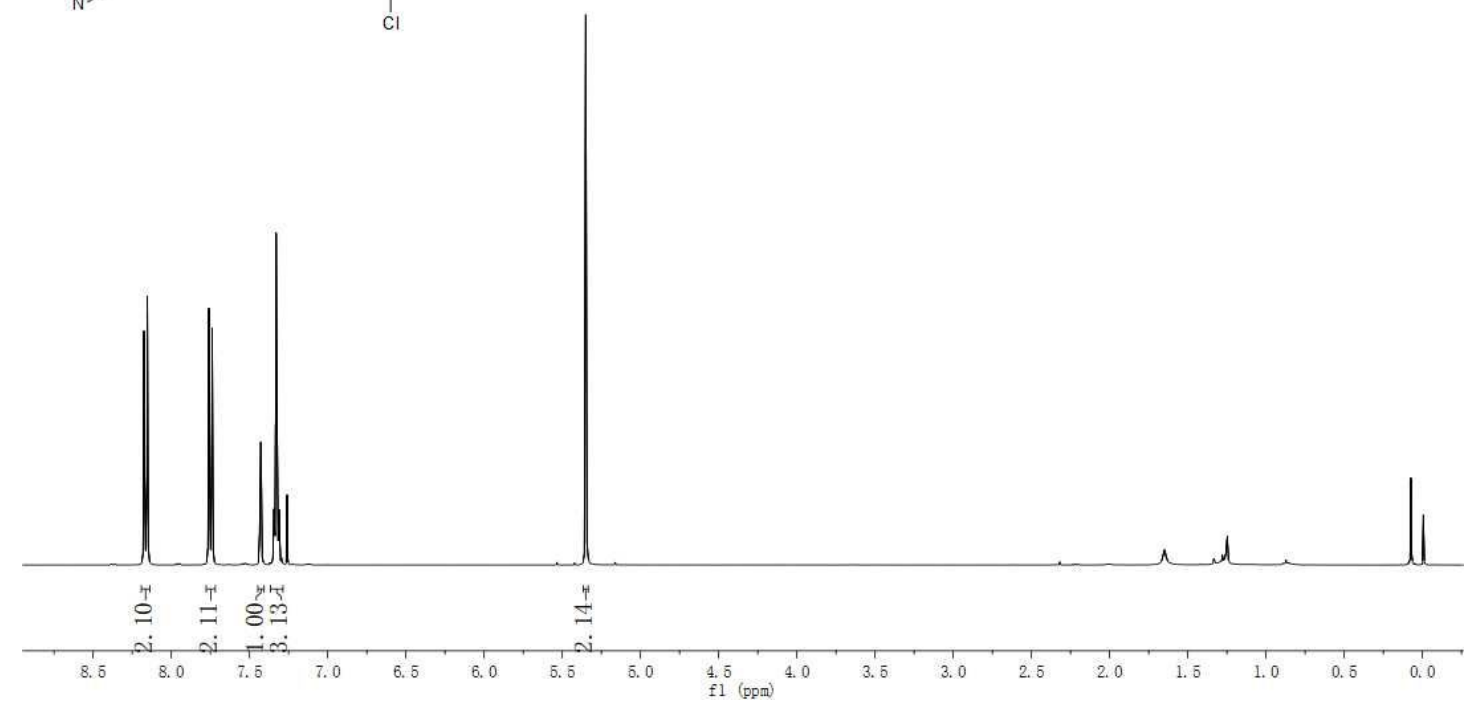

Figure S123. $400 \mathrm{MHz}{ }^{1} \mathrm{H}$ NMR spectrum of $\mathbf{4 y}$ in $\mathrm{CDCl}_{3}$.

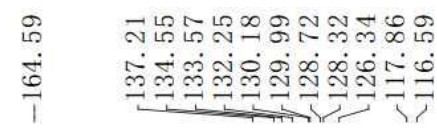

लำ

选造
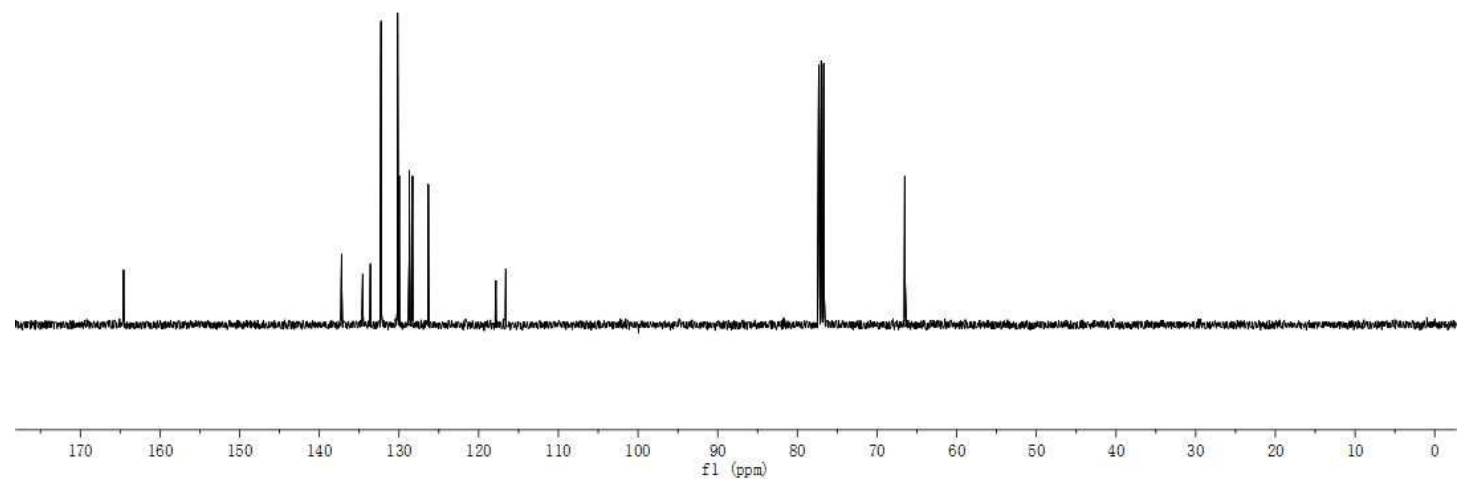

Figure $\mathbf{S 1 2 4} 100 \mathrm{MHz}{ }^{13} \mathrm{C}\left\{{ }^{1} \mathrm{H}\right\}$ NMR spectrum of $\mathbf{4 y}$ in $\mathrm{CDCl}_{3}$. 


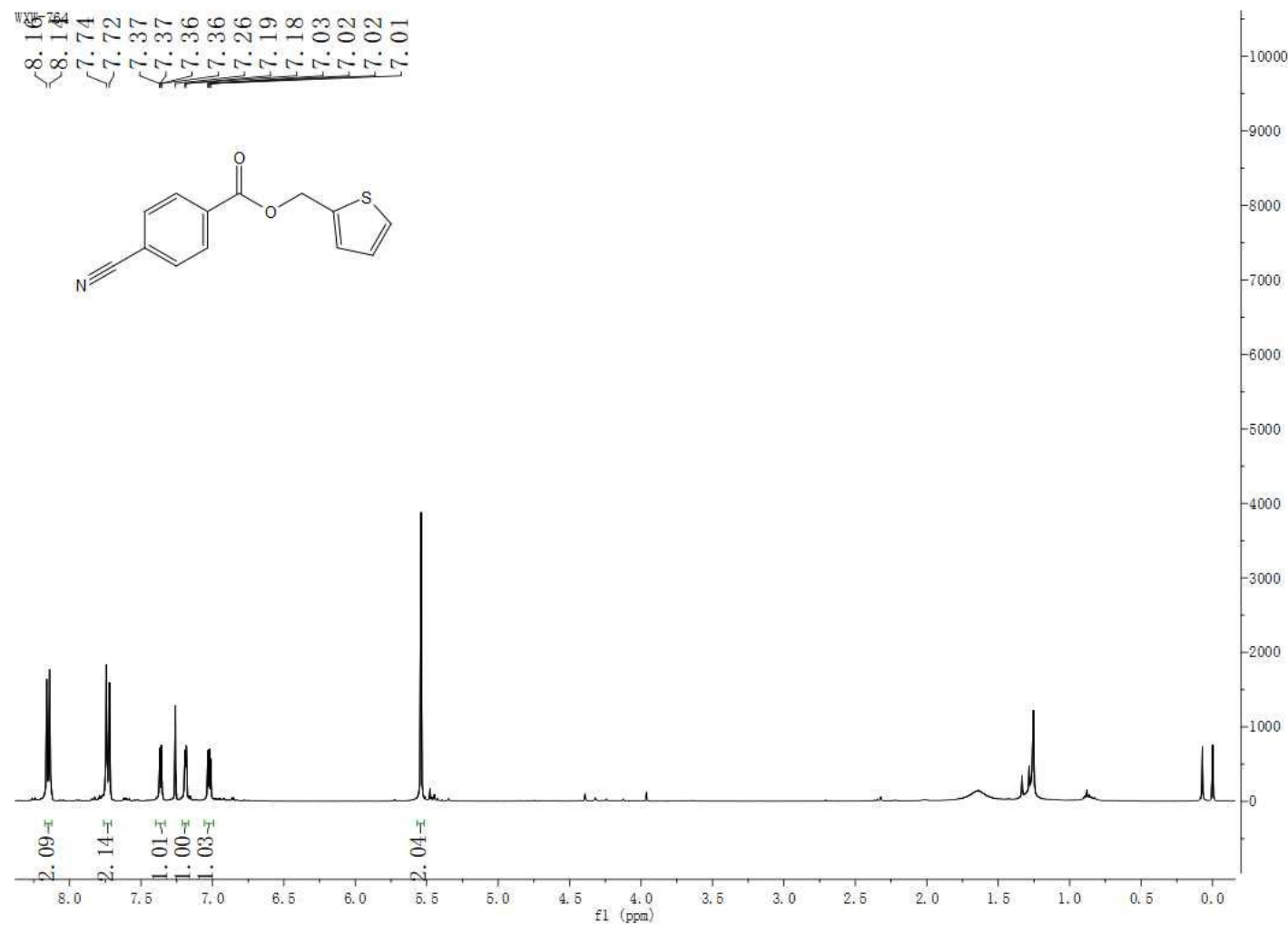

Figure S125. $400 \mathrm{MHz}{ }^{1} \mathrm{H}$ NMR spectrum of $\mathbf{4 z}$ in $\mathrm{CDCl}_{3}$.

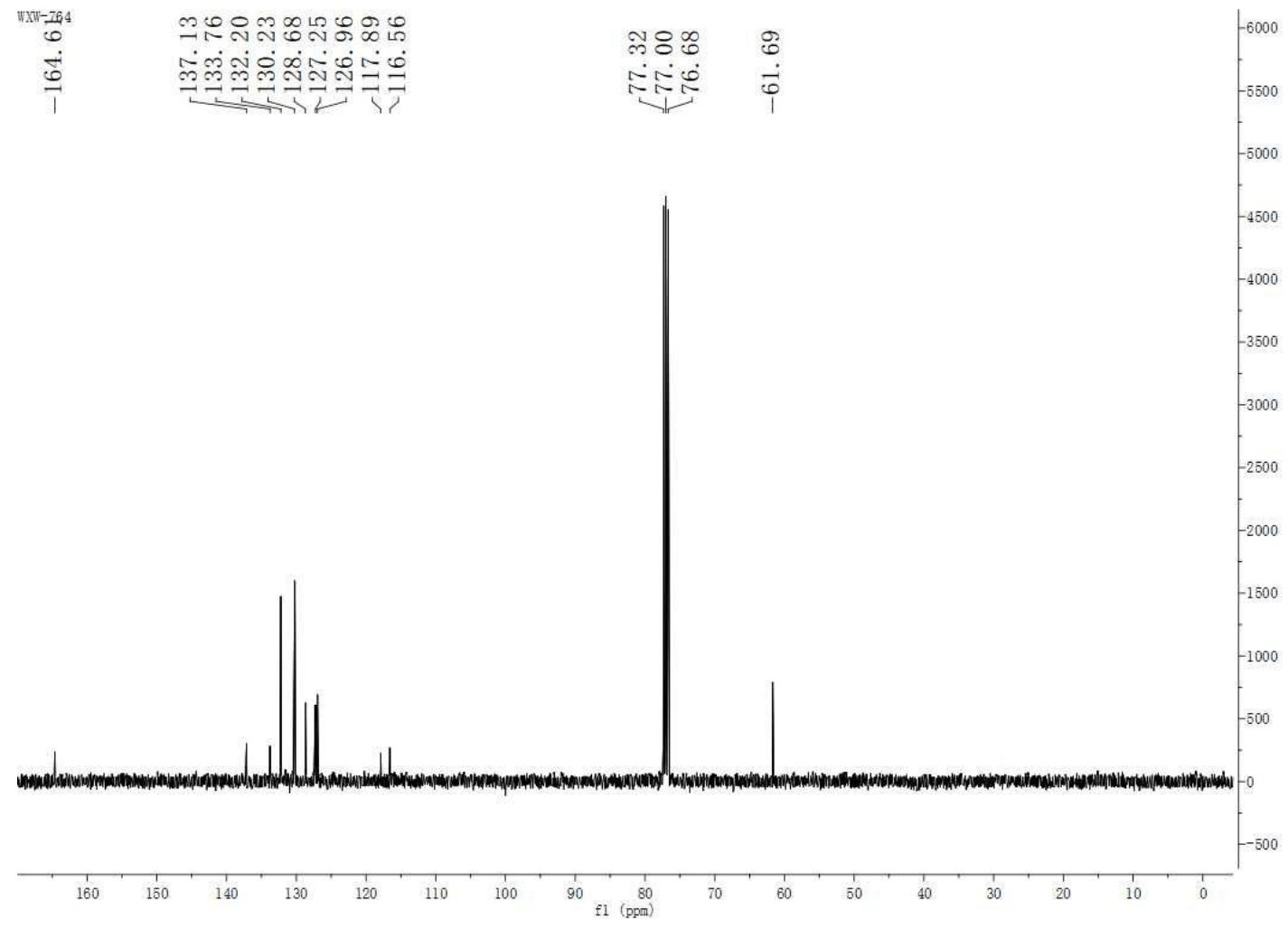

Figure $\mathbf{S 1 2 6} 100 \mathrm{MHz}{ }^{13} \mathrm{C}\left\{{ }^{1} \mathrm{H}\right\} \mathrm{NMR}$ spectrum of $\mathbf{4 z}$ in $\mathrm{CDCl}_{3}$. 


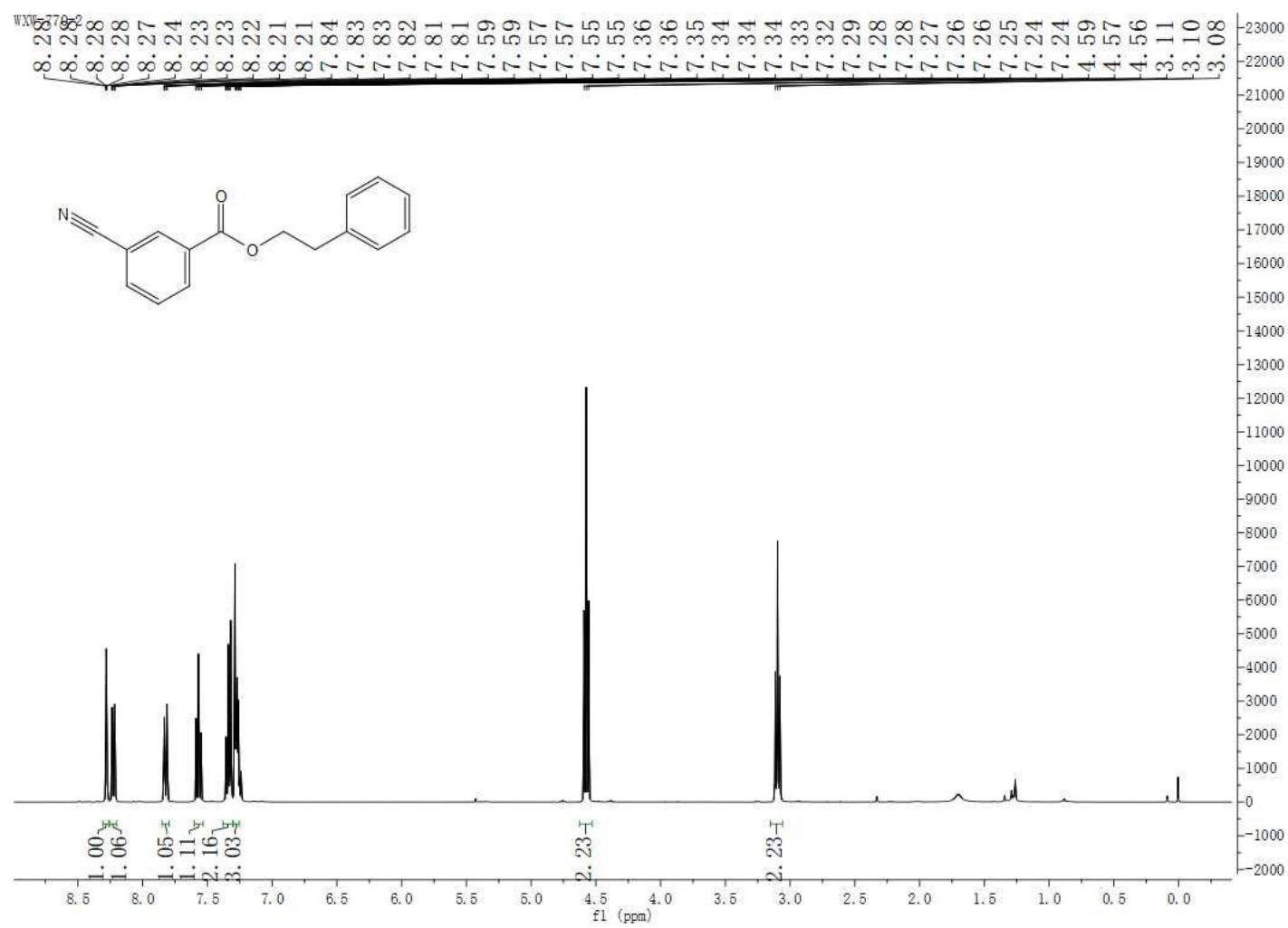

Figure S127. $400 \mathrm{MHz}{ }^{1} \mathrm{H} \mathrm{NMR}$ spectrum of $4 \mathbf{a a}$ in $\mathrm{CDCl}_{3}$.

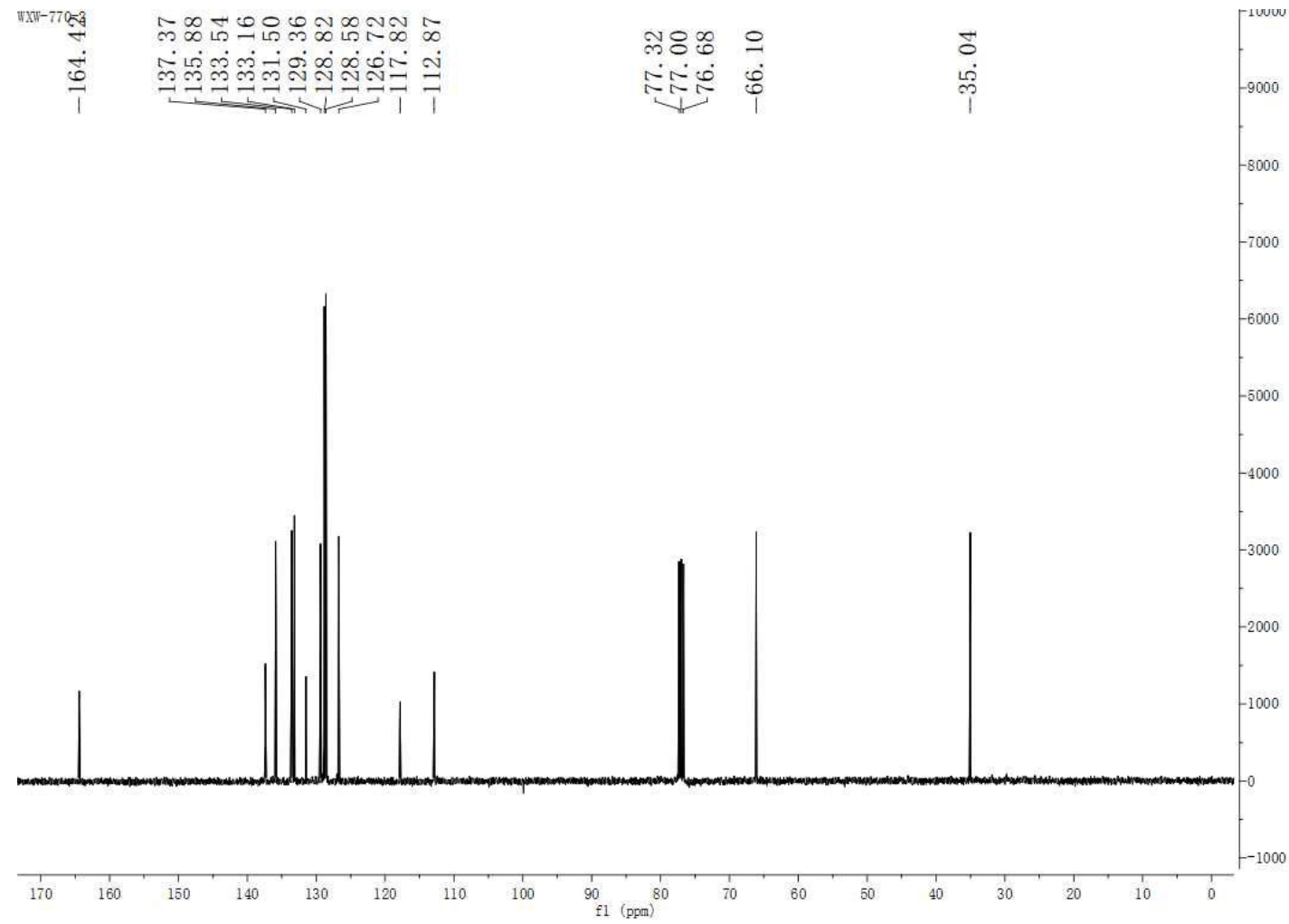

Figure $\mathbf{S 1 2 8} 100 \mathrm{MHz}{ }^{13} \mathrm{C}\left\{{ }^{1} \mathrm{H}\right\}$ NMR spectrum of $\mathbf{4 a a}$ in $\mathrm{CDCl}_{3}$. 

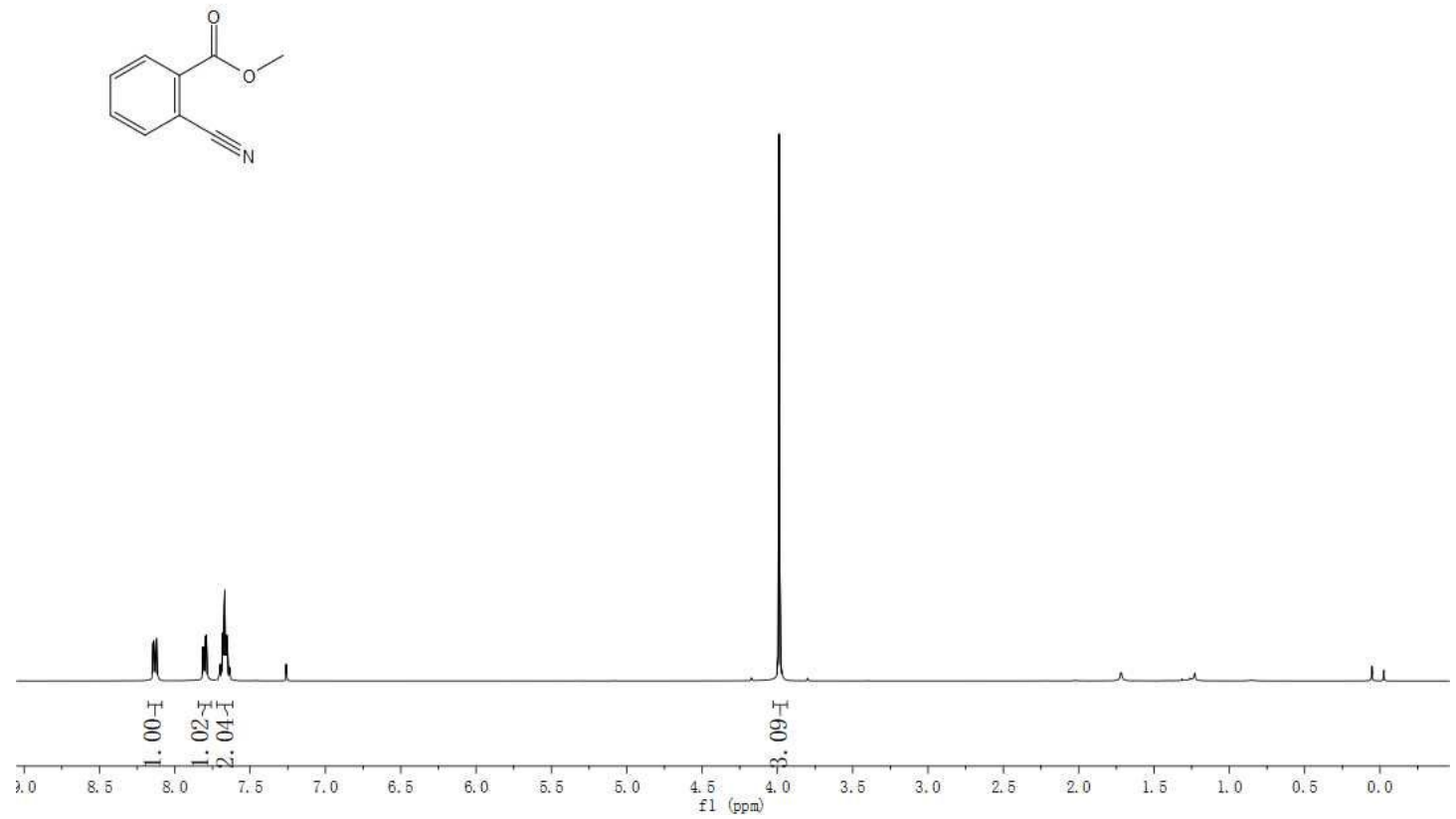

Figure S129. $400 \mathrm{MHz}{ }^{1} \mathrm{H} \mathrm{NMR}$ spectrum of $\mathbf{4 a b}$ in $\mathrm{CDCl}_{3}$.

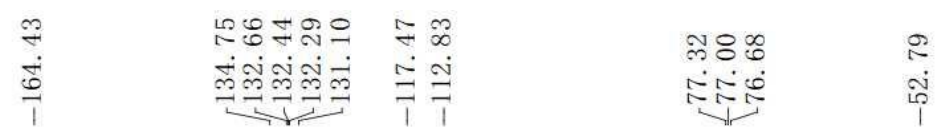
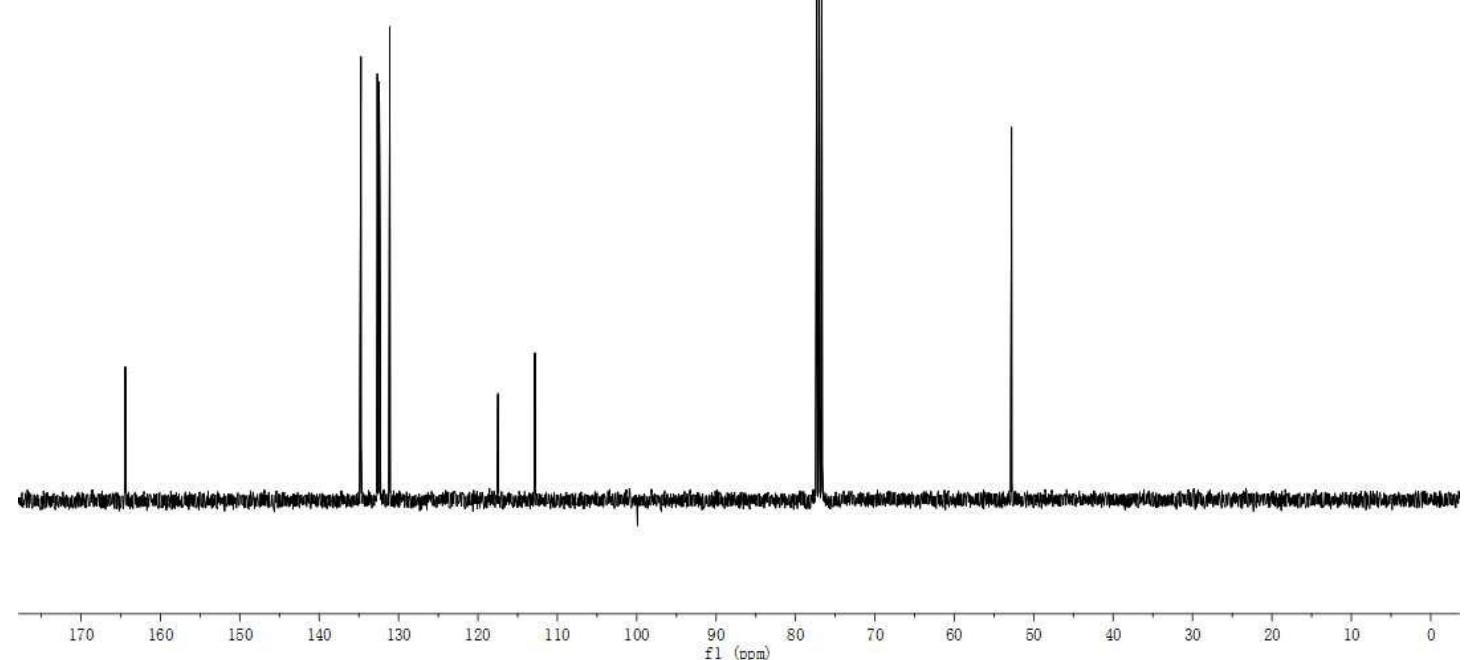

Figure S130 $100 \mathrm{MHz}{ }^{13} \mathrm{C}\left\{{ }^{1} \mathrm{H}\right\}$ NMR spectrum of $\mathbf{4 a b}$ in $\mathrm{CDCl}_{3}$. 
<smiles>CCOC(=O)c1ccccc1C#N</smiles>

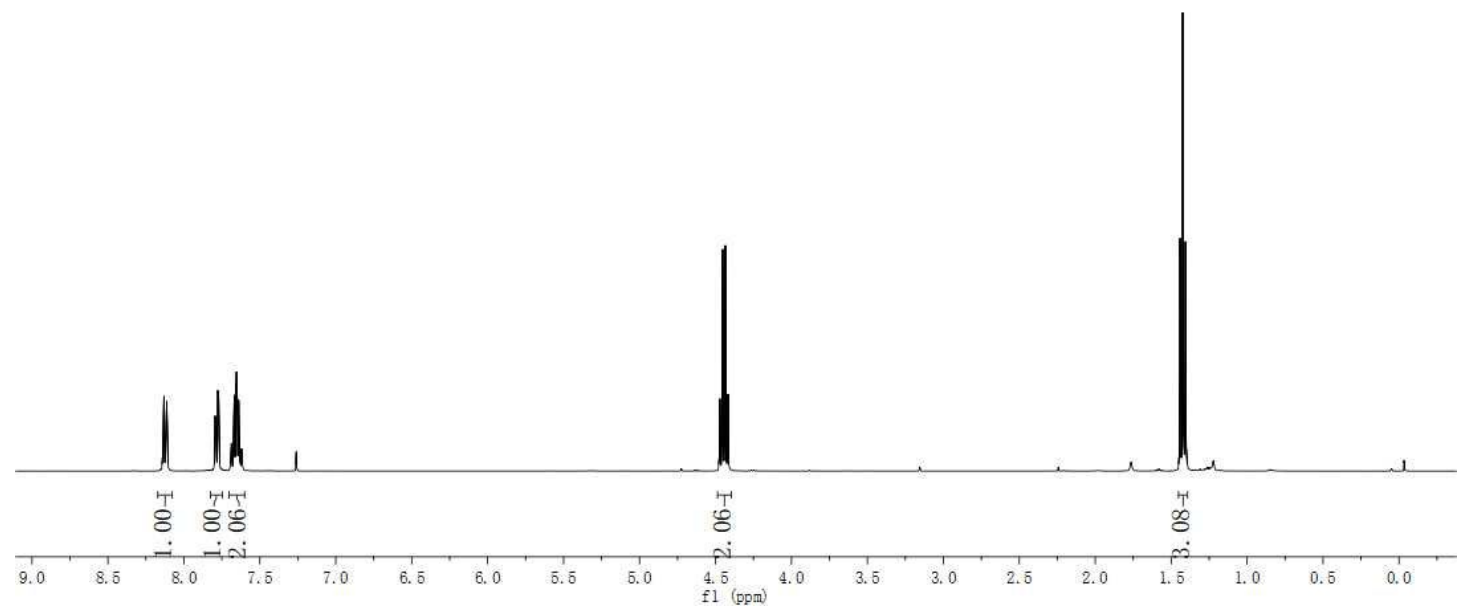

Figure S131. $400 \mathrm{MHz}{ }^{1} \mathrm{H}$ NMR spectrum of $4 \mathbf{a c}$ in $\mathrm{CDCl}_{3}$.

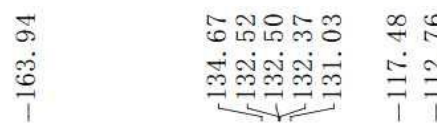

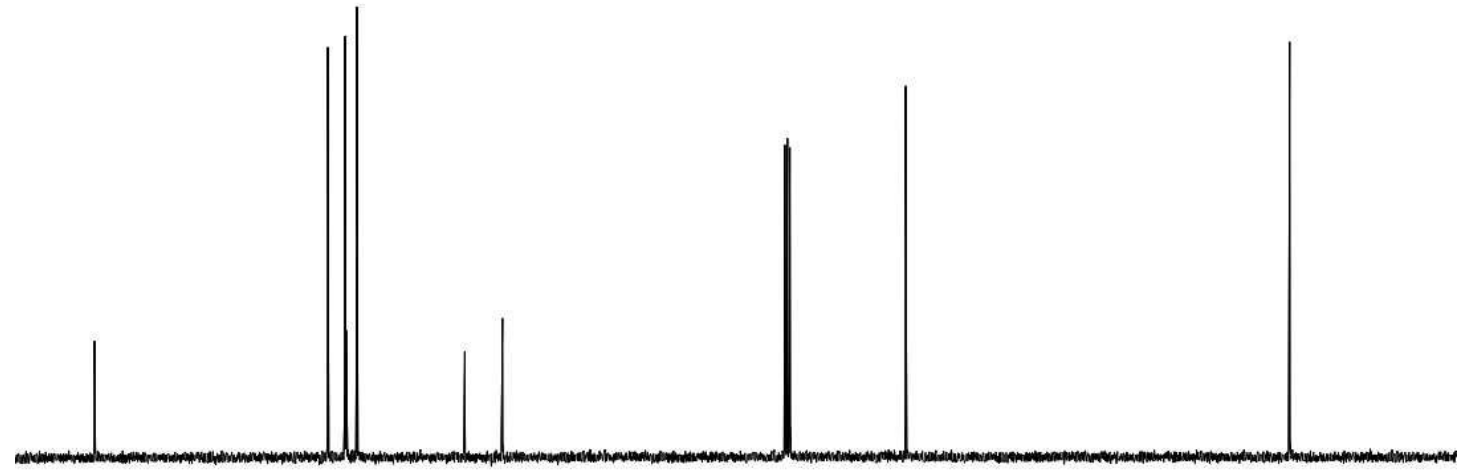

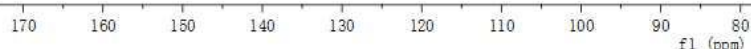

Figure S132 $100 \mathrm{MHz}{ }^{13} \mathrm{C}\left\{{ }^{1} \mathrm{H}\right\}$ NMR spectrum of 4 ac in $\mathrm{CDCl}_{3}$. 


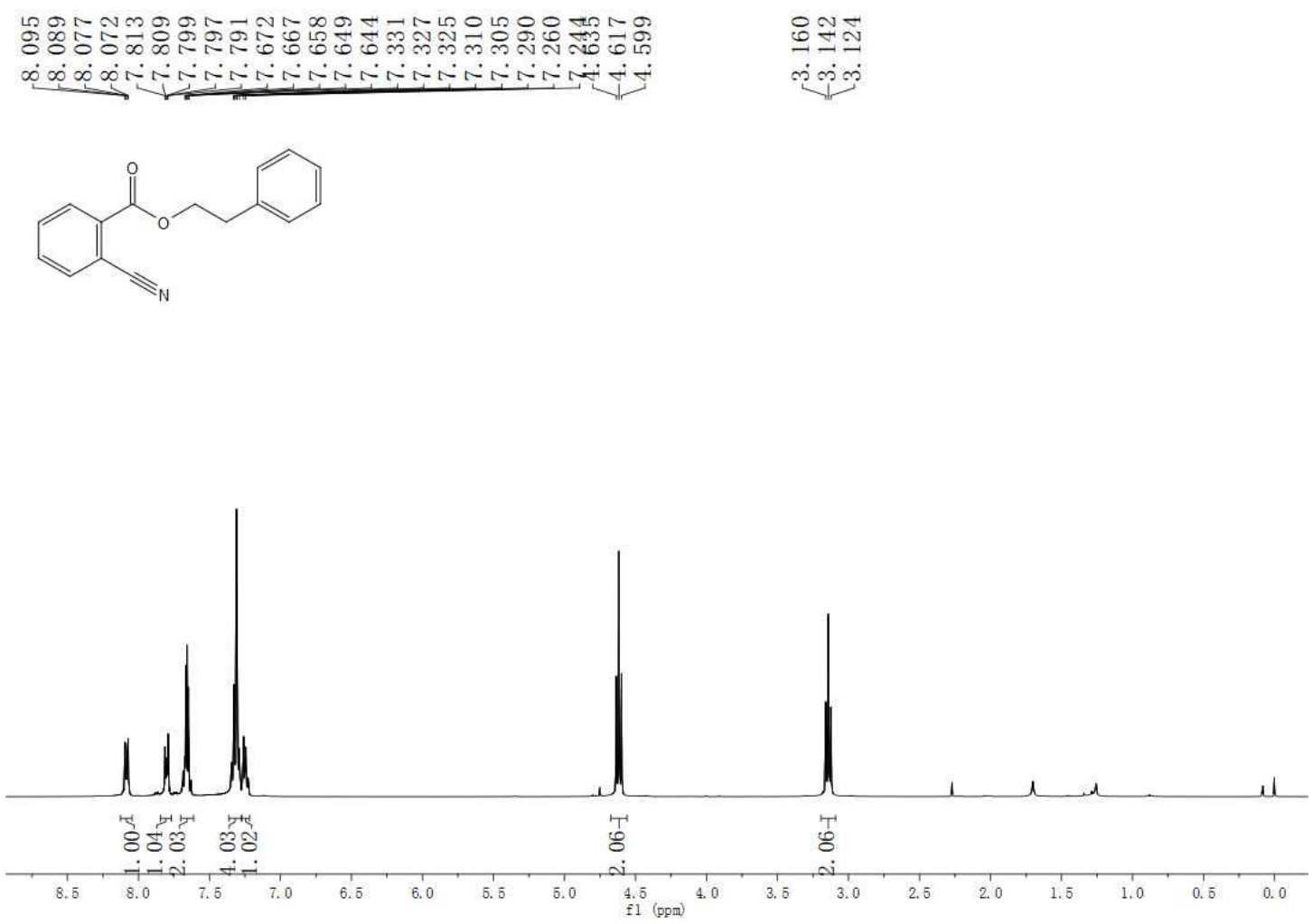

Figure S133. $400 \mathrm{MHz}{ }^{1} \mathrm{H}$ NMR spectrum of 4 ad in $\mathrm{CDCl}_{3}$.

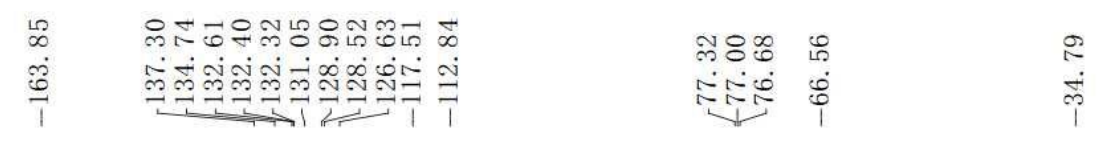
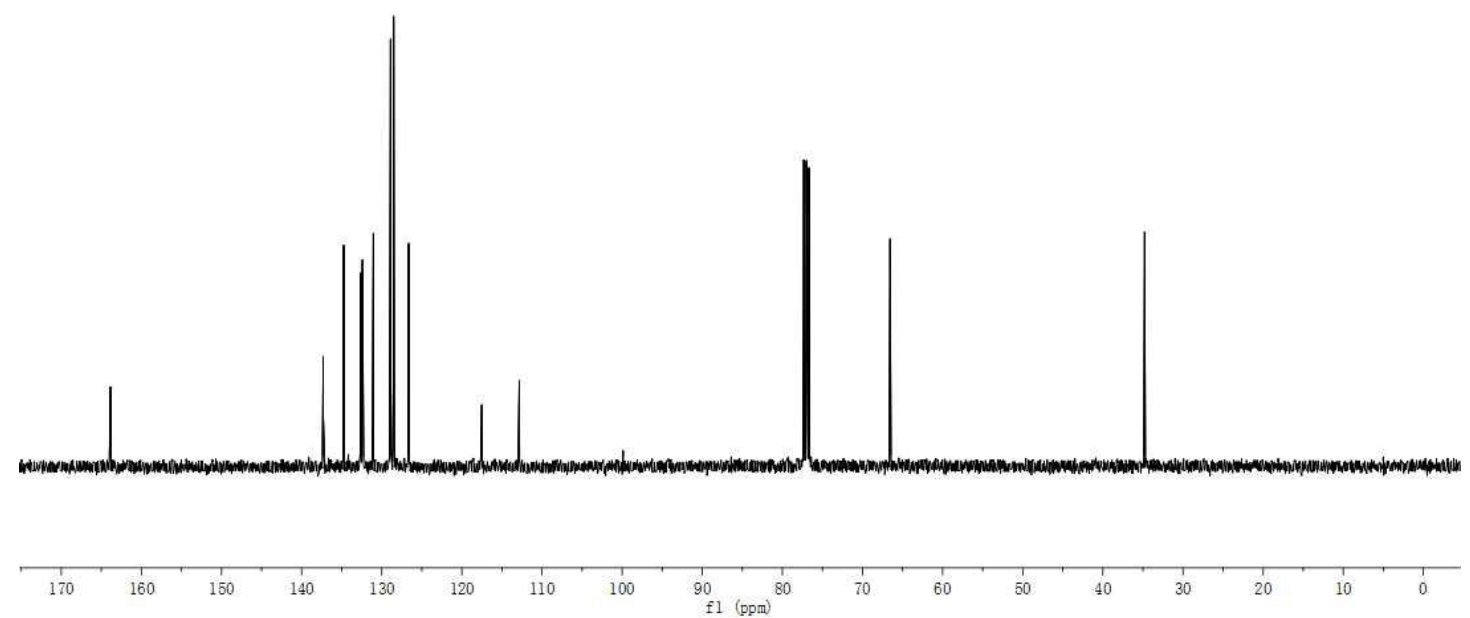

Figure $\mathbf{S 1 3 4} 100 \mathrm{MHz}{ }^{13} \mathrm{C}\left\{{ }^{1} \mathrm{H}\right\} \mathrm{NMR}$ spectrum of $\mathbf{4 a d}$ in $\mathrm{CDCl}_{3}$. 


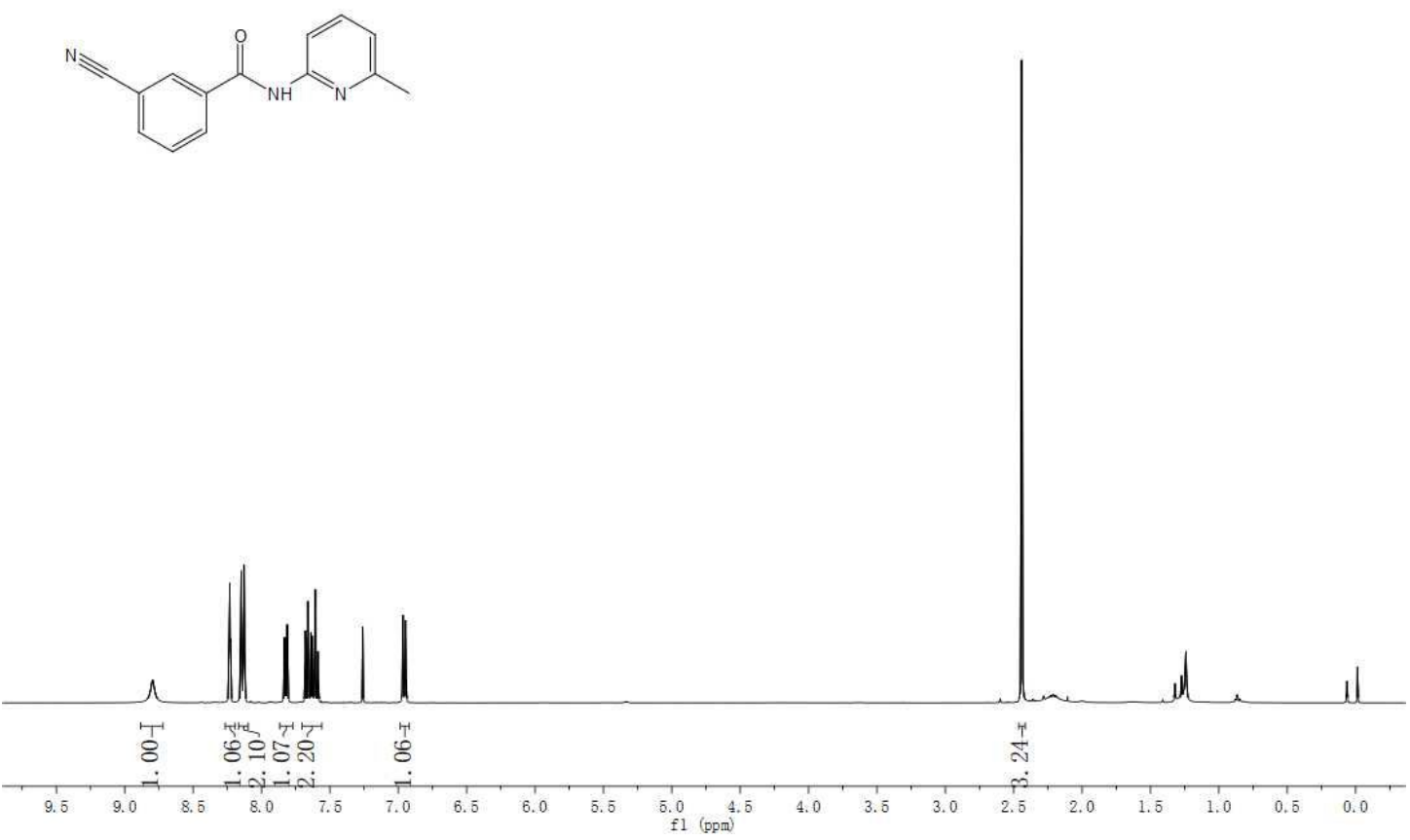

Figure S135. $400 \mathrm{MHz}{ }^{1} \mathrm{H}$ NMR spectrum of $\mathbf{5 a}$ in $\mathrm{CDCl}_{3}$.

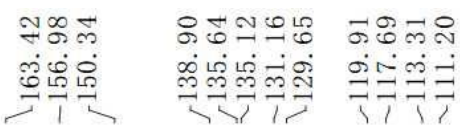
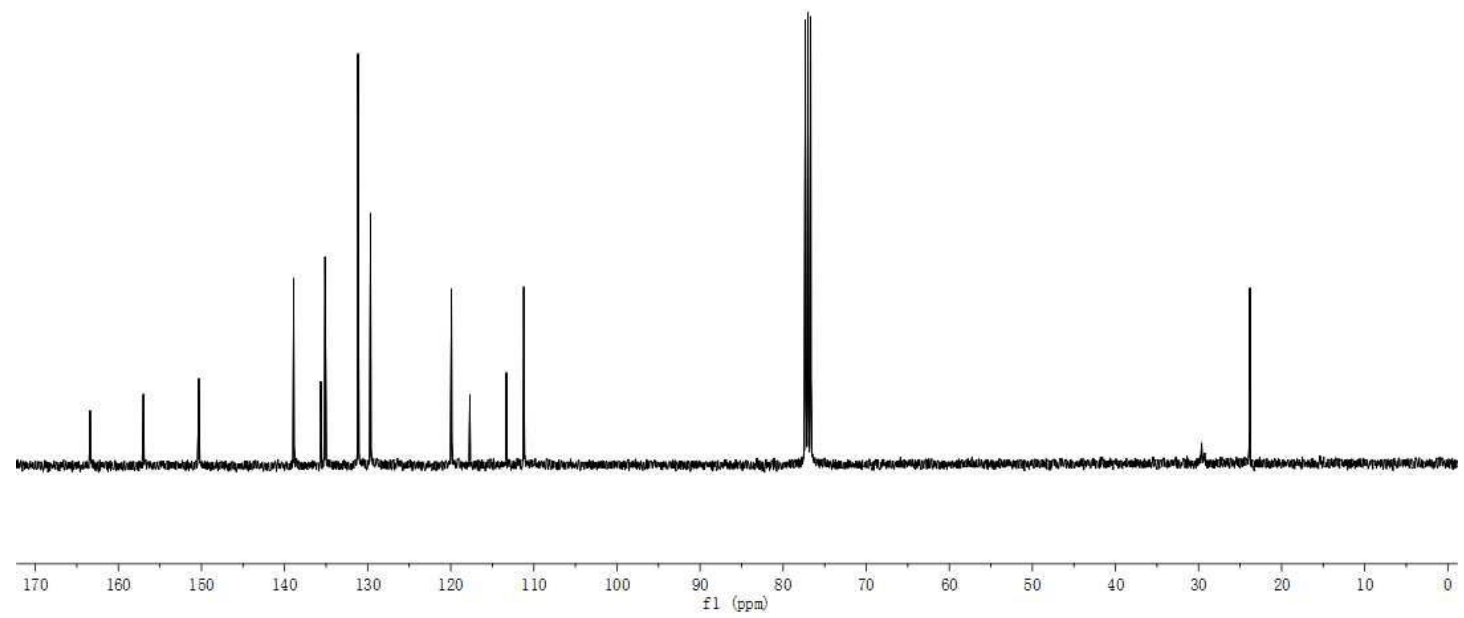

Figure S136 $100 \mathrm{MHz}{ }^{13} \mathrm{C}\left\{{ }^{1} \mathrm{H}\right\}$ NMR spectrum of 5a in $\mathrm{CDCl}_{3}$. 

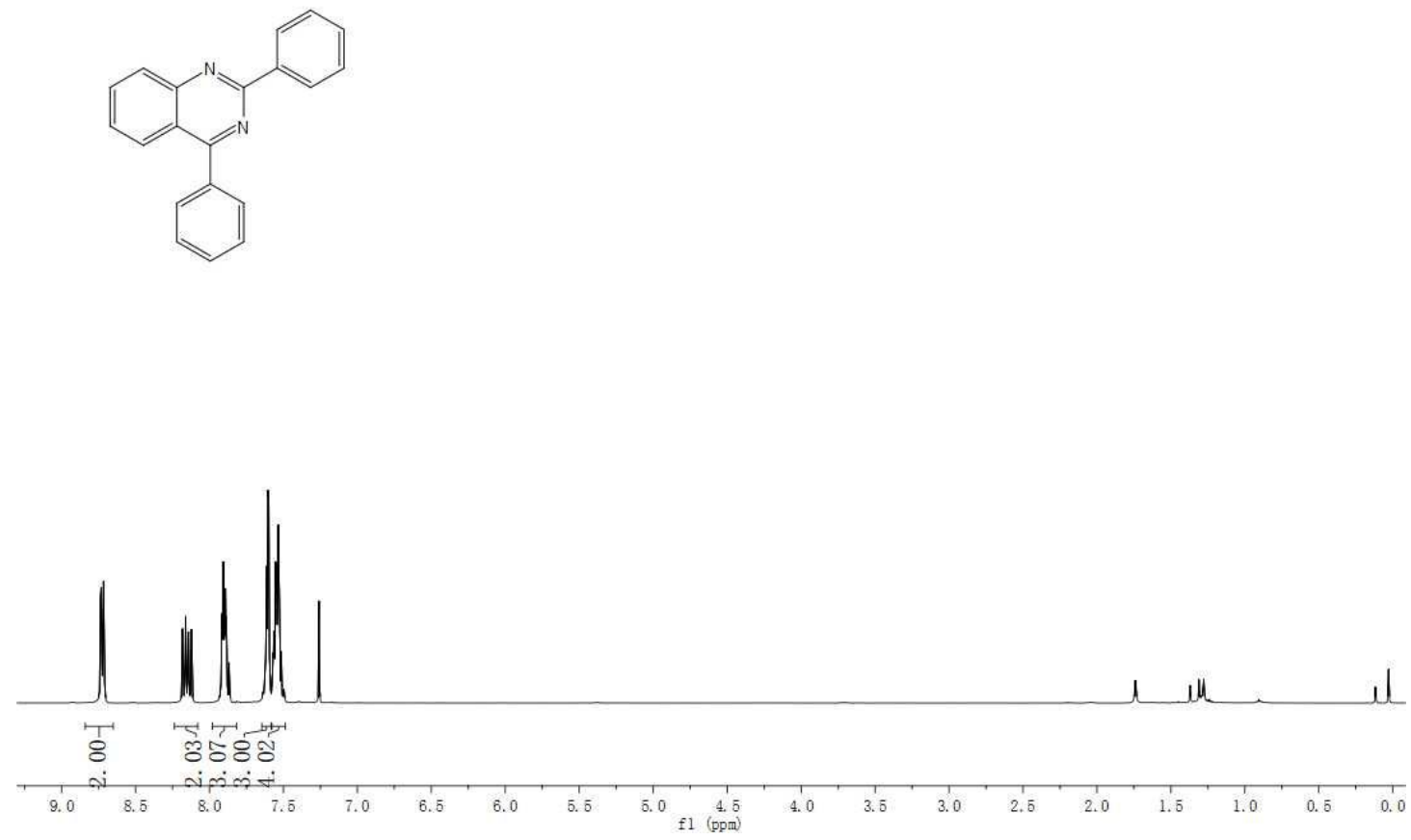

Figure $\mathbf{S 1 3 7 .} 400 \mathrm{MHz}{ }^{1} \mathrm{H}$ NMR spectrum of $\mathbf{5 b}$ in $\mathrm{CDCl}_{3}$.

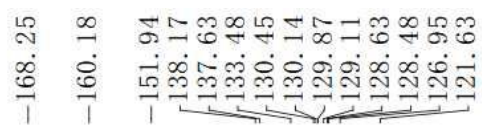

กิ8:

숭
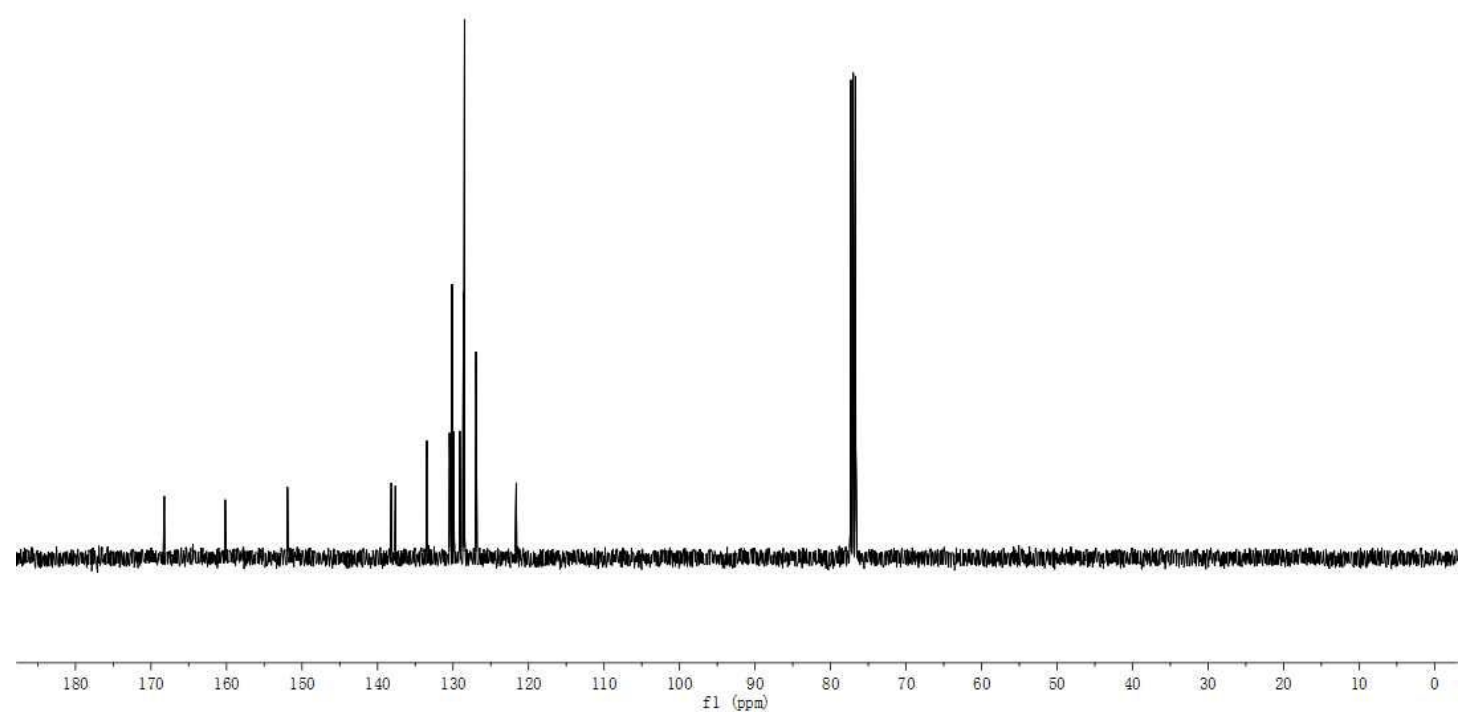

Figure $\mathbf{S 1 3 8} 100 \mathrm{MHz}{ }^{13} \mathrm{C}\left\{{ }^{1} \mathrm{H}\right\} \mathrm{NMR}$ spectrum of $\mathbf{5 b}$ in $\mathrm{CDCl}_{3}$. 


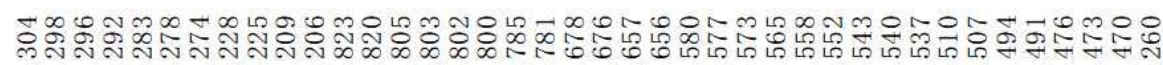

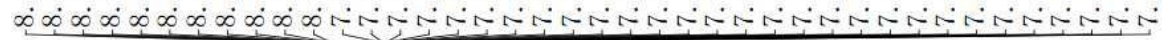

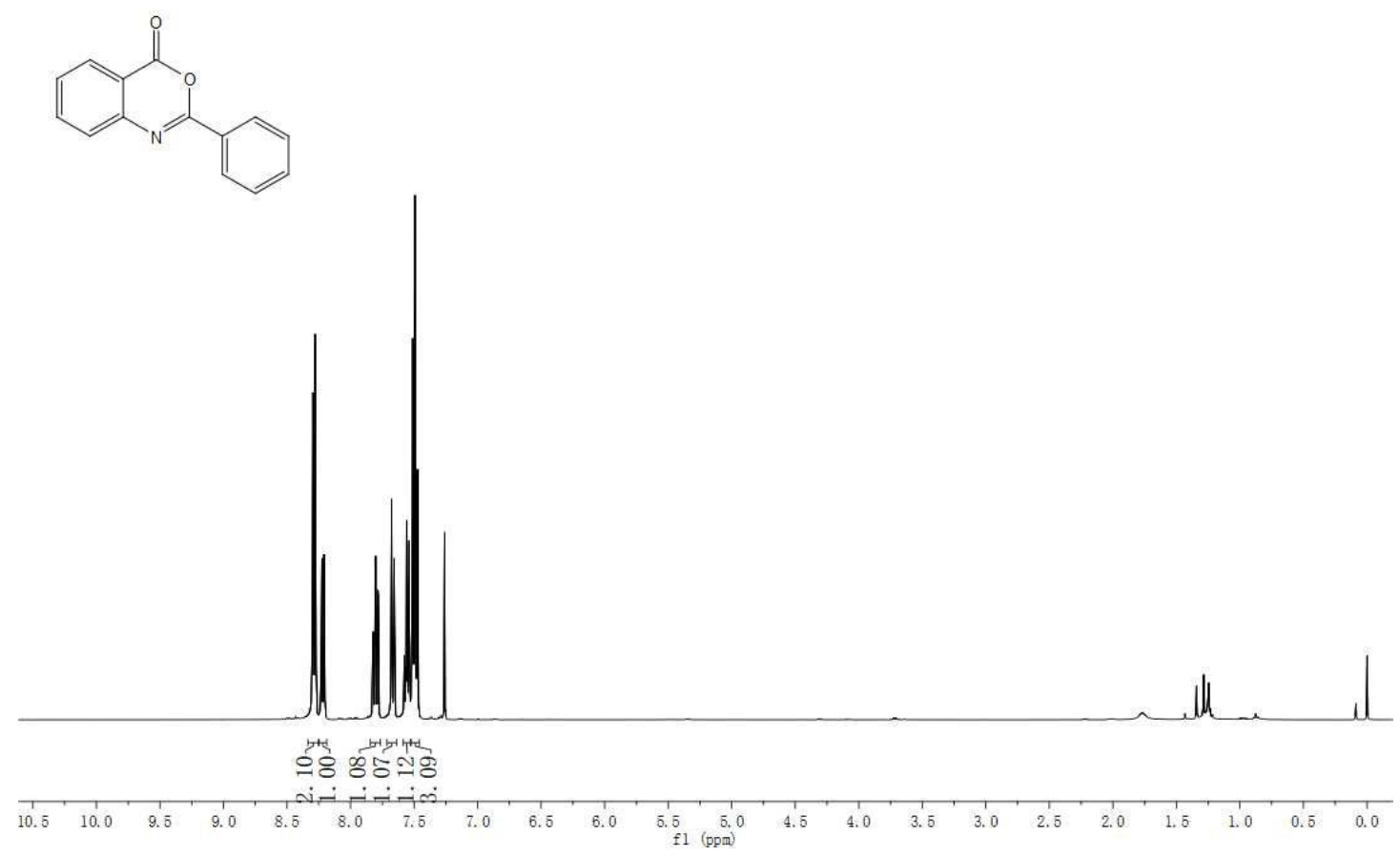

Figure S139. $400 \mathrm{MHz}{ }^{1} \mathrm{H}$ NMR spectrum of $5 \mathbf{c}$ in $\mathrm{CDCl}_{3}$.

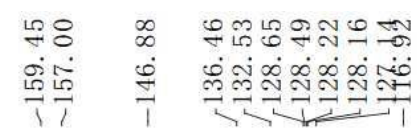

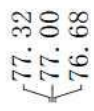
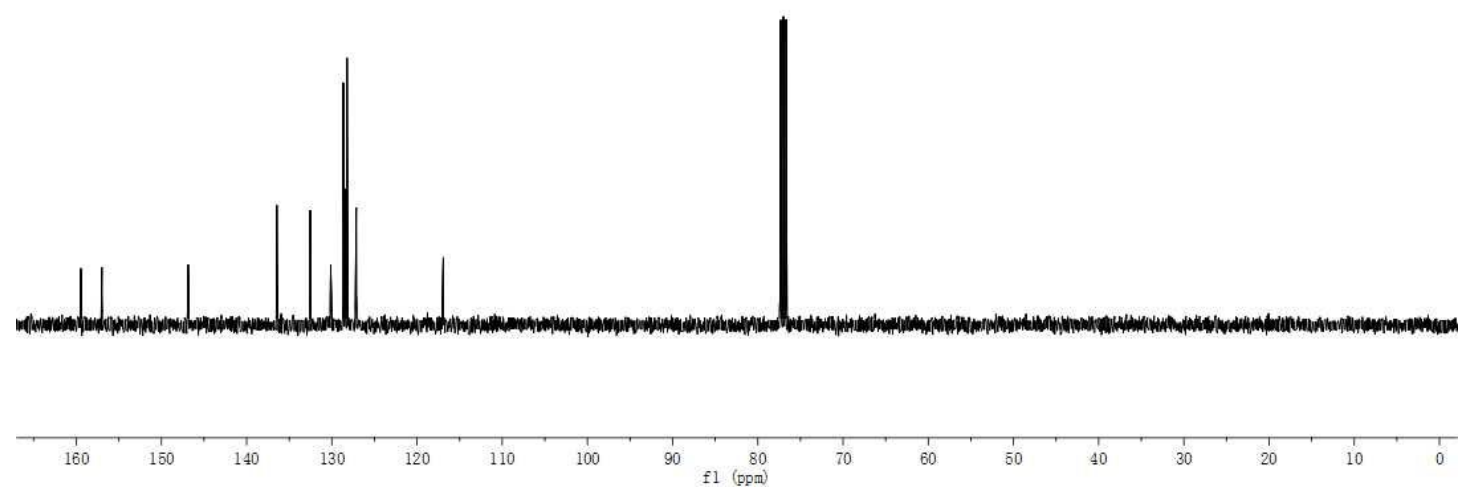

Figure $\mathbf{S 1 4 0} 100 \mathrm{MHz}{ }^{13} \mathrm{C}\left\{{ }^{1} \mathrm{H}\right\} \mathrm{NMR}$ spectrum of $\mathbf{5 c}$ in $\mathrm{CDCl}_{3}$. 


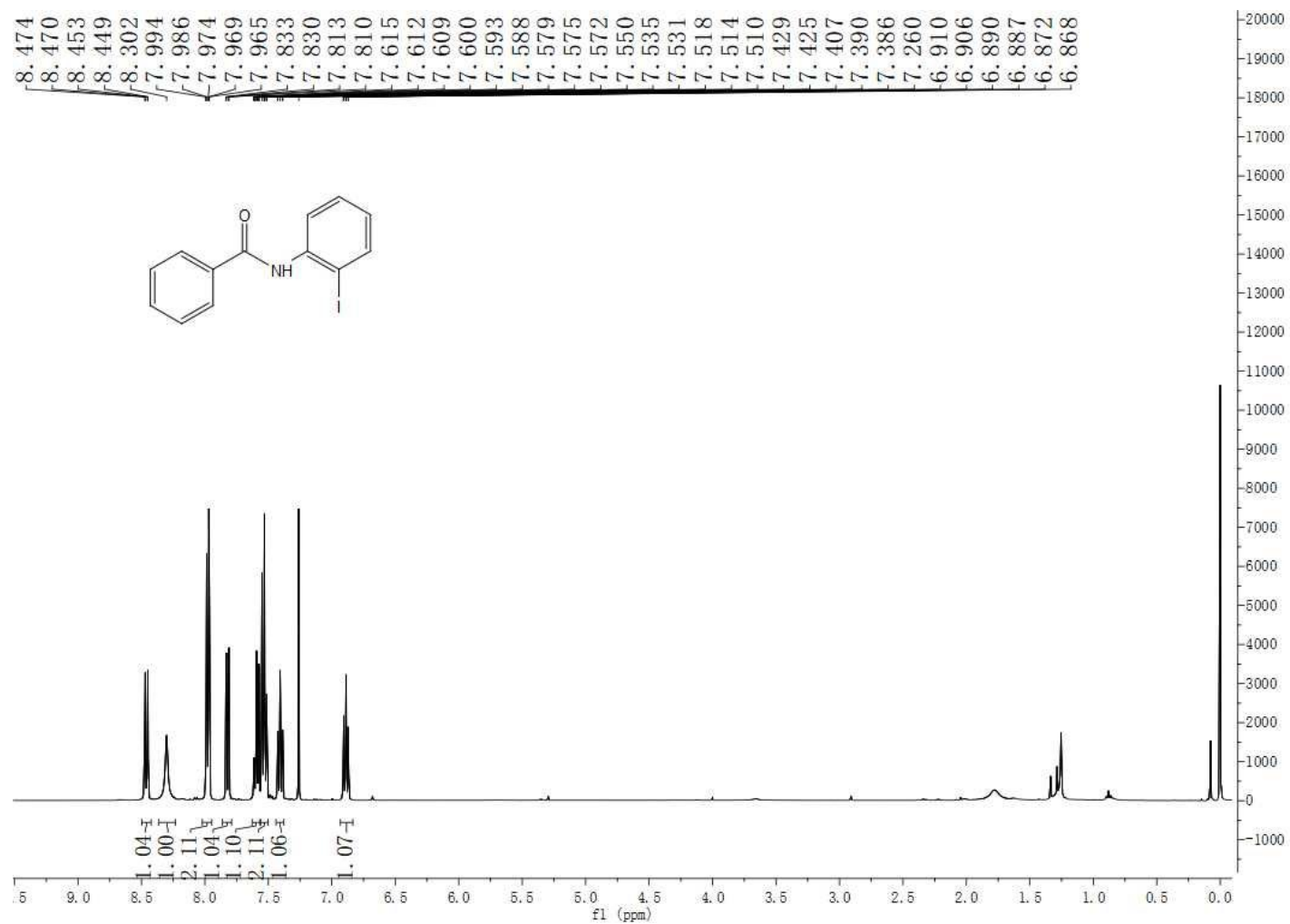

Figure S141. $400 \mathrm{MHz}{ }^{1} \mathrm{H}$ NMR spectrum of $\mathbf{6 a}$ in $\mathrm{CDCl}_{3}$.

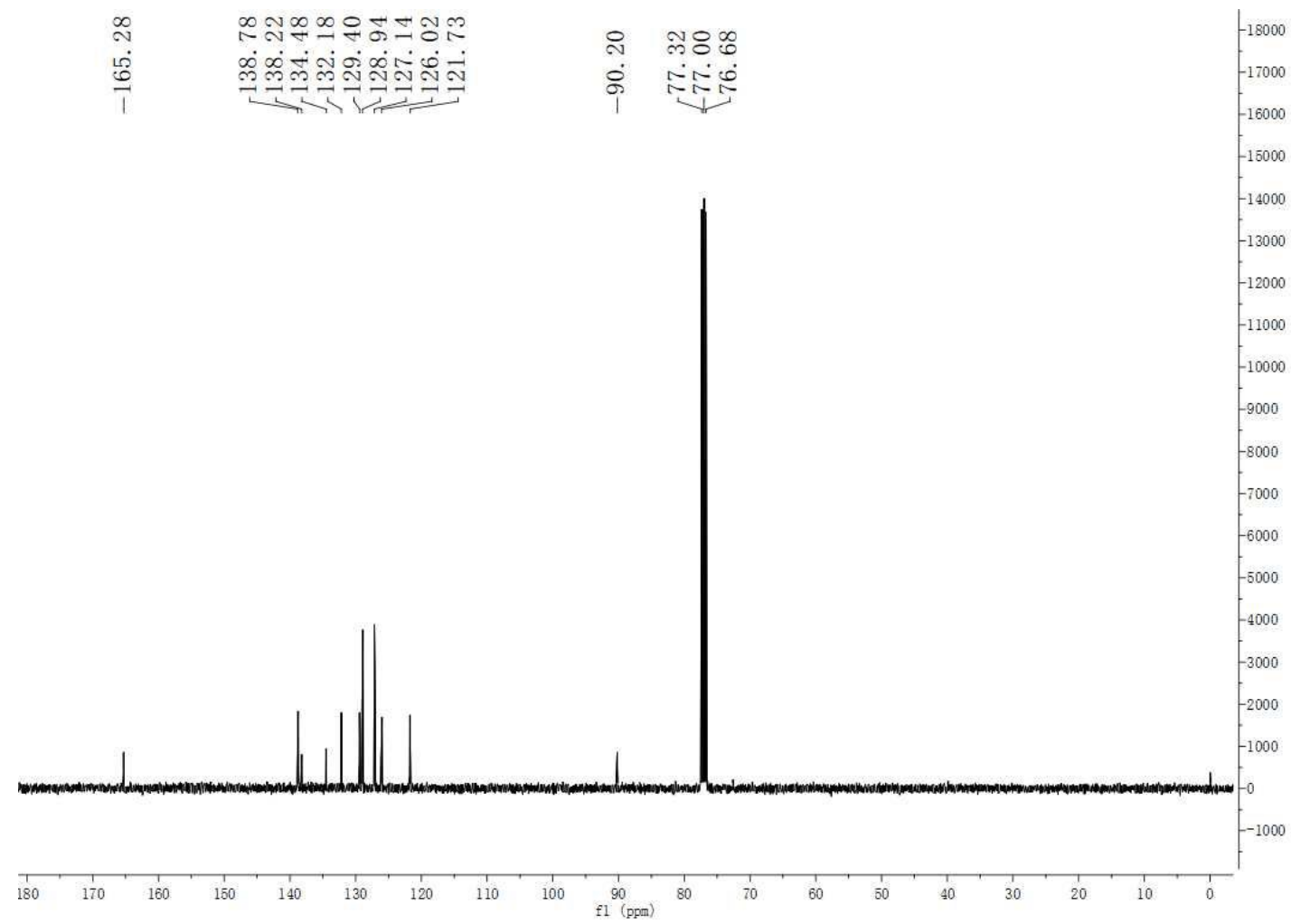

Figure $\mathbf{S 1 4 2} 100 \mathrm{MHz}{ }^{13} \mathrm{C}\left\{{ }^{1} \mathrm{H}\right\} \mathrm{NMR}$ spectrum of $\mathbf{6 a}$ in $\mathrm{CDCl}_{3}$. 